PEDRO HENRIQUE MAGALHÃES CARDOSO

O Sistema APPCC como delineamento técnico para criação e implementação de programas de autocontrole sanitário em estabelecimentos atacadistas de peixes ornamentais 


\section{O Sistema APPCC como delineamento técnico para criação e implementação de programas de autocontrole sanitário em estabelecimentos atacadistas de peixes ornamentais}

Tese apresentada ao Programa de PósGraduação em Epidemiologia Experimental Aplicada às Zoonoses da Faculdade de Medicina Veterinária e Zootecnia da Universidade de São Paulo para obtenção do título de Doutor em Ciências.

\section{Departamento:}

Medicina Veterinária Preventiva e Saúde Animal

Área de concentração:

Epidemiologia Experimental Aplicada às Zoonoses

Orientadora:

Profa. Dra. Simone de Carvalho Balian 
Autorizo a reproduçäo parcial ou total desta obra, para fins acadêmicos, desde que citada a fonte.

DADOS INTERNACIONAIS DE CATALOGAÇÃo NA PUBLICAÇÃo

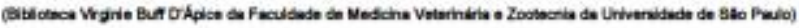

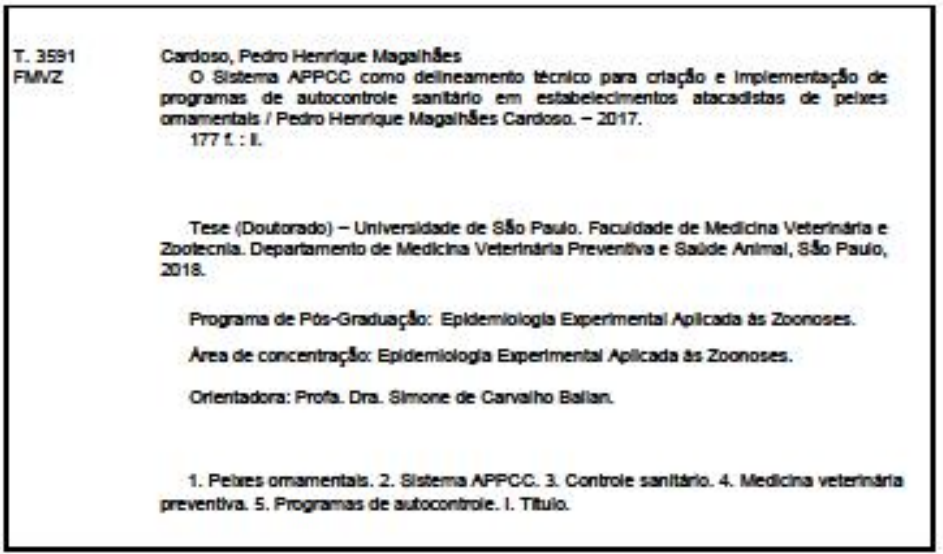

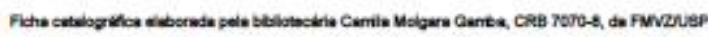


IImo(a). Sr(a).

Responsável: Simone De Carvalho Balian

Área: Vps/fmvz

Equipe envolvida: Pedro Henrique Magalhäes Cardoso - executor (--); Simone De Carvalho Balian (orientador)

Título do projeto: "Ávaliaçâo das condiçōes para elaboraçâo e aplicação da metodologia HACCP em comércios atacadistas de Peixes Ornamentais na cidade de Sâo Paulo".

\section{Parecer Consubstanciado da CEUA FMVZ/USP}

O estudo objetiva avaliar as condiçōes para aplicação e implantação da metodologia HACCP em estabelecimento atacadista de peixes ornamentais, no intuito de prevenir a disseminação de agentes patogênicos prejudiciais a saúde dos peixes e do homem, bem como fornecer animais de qualidade para o consumidor. 0 trabalho pretende, ainda, alertar sobre a importância do tema que hoje recebe pouca ou nenhuma atençâo cientifica no país, considerando a sua relevância sanitária e econßmica.

A Comissão de Ética no Uso de Animais da Faculdade de Medicina Veterinária e Zootecnia da Universidade de Säo Paulo, na reunião de 25/02/2015, ANALISOU e APROVOU o protocolo de estudo acima referenciado. A partir desta data, é dever do pesquisador.

1. Comunicar toda e qualquer alteraçầo do protocolo.

2. Comunicar imediatamente ao Comite qualquer evento adverso ocorrido durante o desenvolvimento do protocolo.

3. Os dados individuais de todas as etapas da pesquisa devem ser mantidos em local seguro por 5 anos para possivel auditoria dos orgăos competentes.

4. Relatórios parciais de andamento deverâo ser enviados anualmente à CEUA até a conclusâo do protocolo.

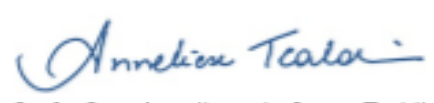

Profa. Dra. Anneliese de Souza Traldi Presidente da Comissấo de Ética no Uso de Animais

Faculdade de Medicina Veterinária e Zootecnia da Universidade de São Paulo

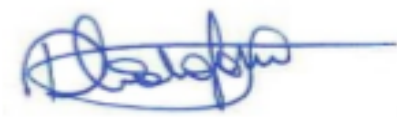

Roseli da Costa Gomes Secretária Executiva

Faculdade de Medicina Veterinária e Zootecnia da Universidade de Säo Paulo

Av. Prof. Dr. Orlando Marques de Paiva, 87, Cidade Universitária: Armando de Salles Oliveira CEP 05508-270 såo Paulo/SP - Brasil - tel: 55 (11) 3091-7676 / fax: 55 (11) $3032-2224$ Horário de atendimento: $2^{2}$ a $5^{2}$ das $7 \mathrm{~h} 30$ às $16 \mathrm{~h}:$ : e-mail: ceuavet $@$ usp.br 


\section{CERTIFIED}

We certify that the Research "Evaluation of conditions for development and implementation of HACCP methodology in wholesale trade of Tropical Fish in São Paulo", protocol number CEUAx 4516111214, under the responsibility Simone De Carvalho Balian, agree with Ethical Principles in Animal Research adopted by Ethic Committee in the Use of Animals of School of Veterinary Medicine and Animal Science (University of Sào Paulo), and was approved in the meeting of day February 25, 2015.

Certificamos que o protocolo do Projeto de Pesquisa intitulado "Avaliação das condições para elaboração e aplicação da metodologia HACCP em comércios atacadistas de Peixes Ornamentais na cidade de Sâo Paulo", protocolado sob o CEUAx $n^{\circledR}$ 4516111214, sob a responsabilidade de Simone De Carvalho Balian, está de acordo com os princípios éticos de experimentaçầo animal da Comissão de Ética no Uso de Animais da Faculdade de Medicina Veterinária e Zootecnia da Universidade de São Paulo, e foi aprovado na reuniäo de 25 de fevereiro de 2015 .

$$
\text { Mnneliar Tala. }
$$

Profa. Dra. Anneliese de Souza Traldi Presidente da Comissâo de Ética no Uso de Animais

Faculdade de Medicina Veterinária e Zootecnia da Universidade Faculdade de Medicina Veterinária e Zootecnia da Universidade de São Paulo

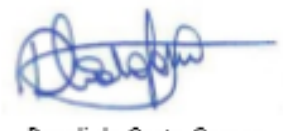

Roseli da Costa Gomes

Secretária Executiva de Sâo Paulo 


\section{FOLHA DE AVALIAÇÃO}

Autor: CARDOSO, Pedro Henrique Magalhães

Título: O Sistema APPCC como delineamento técnico para criação e implementação de programas de autocontrole sanitário em estabelecimentos atacadistas de peixes ornamentais.

Tese apresentada ao Programa de Pós-Graduação em Epidemiologia Experimental Aplicado às Zoonoses da

Faculdade de Medicina Veterinária e Zootecnia da Universidade de São Paulo para o título de Doutor em Ciências

Data:

Banca Examinadora

Professor. Dr.

Instituição: Julgamento:

Professor. Dr.

Instituição: Julgamento:

Professor. Dr.

Instituição: Julgamento:

Professor. Dr.

Instituição: Julgamento:

Professor. Dr.

Instituição: Julgamento: 


\section{DEDICATÓRIA}

Aos animais que diariamente são explorados e geram fonte de renda e lucro para os seres humanos, e quase sempre não recebem o devido cuidado e respeito que merecem. 


\section{AGRADECIMENTOS}

Primeiramente gostaria de agradecer ao Universo por ter me dado a oportunidade de viver no Planeta Terra e aprender diariamente as duras lições que a vida tem a nos ensinar.

Em seguida ao professor Ricardo Augusto Dias por ter me dado a oportunidade do ingresso no Programa de Pós Graduação em Epidemiologia Experimental Aplicado às Zoonoses e ter me apresentado à minha orientadora Simone de Carvalho Balian que por sua vez acreditou em mim e me apoiou inteiramente no desenvolvimento do projeto.

Ao empresário Kiuslei Cassiolato e toda a equipe da empresa Ipiranga Peixes Ornamentais por ter oferecido o cenário e todos os dados necessários (inclusive amostras de peixes ornamentais doentes) para o desenvolvimento desta tese.

Aos professores Andrea Micke Moreno (FMVZ/USP) e Ricardo Luiz Moro (FZEA/USP) que fizeram parte da minha banca de qualificação e desde então tem gentilmente recebido amostras em seus laboratórios para diagnóstico bacteriano e viral respectivamente, assim como todos os envolvidos no diagnóstico nos respectivos laboratórios em especial a Paula Santos da Silva (Laboratório de Sanidade Suína - FMVZ/USP) e Samara Rita de Lucca Maganha (Laboratório de Higiene Zootécnica - FZEA/USP). E ainda à Sandra Abelardo Sanches (Laboratório de Higiene Alimentar - FMVZ/USP) por ter me auxiliado nos exames de qualidade microbiológica da água.

Ao professor Francisco Javier Hernandez Blazquez e a professora Simone de Carvalho Balian por todos os convites feitos para ministrar aulas nas disciplinas VCI 205 Introdução à atuação do Médico Veterinário em Espécies Aquáticas e VPS 445 Sanidade Aquícola respectivamente, para os alunos de graduação da Universidade de São Paulo ao qual pude compartilhar do meu conhecimento técnico nessa área pouco explorada por profissionais Médicos Veterinários.

Ao meu eterno amigo Éder Chacon Martins por ter revisado o resumo em inglês do trabalho. E por fim agradecer a todos os amigos que por ventura eu não tenha citado (pois foram muitos) que desde o dia 28 de janeiro de 2014 partilharam comigo essa jornada, e são parte de tudo isso.

Ao CNPQ (Conselho Nacional de Desenvolvimento Científico e Tecnológico) pela bolsa concedida. 
"Try one, two, three times and if possible try the fourth, fifth, and as many times as necessary. Just do not give up on the first attempts, persistence is a friend of conquest. If you want to get where most do not go, do what most do not."

Bill Gates 


\section{RESUMO}

CARDOSO, P.H.C. O Sistema APPCC como delineamento técnico para criação e implementação de programas de autocontrole sanitário em estabelecimentos atacadistas de peixes ornamentais. [The HACCP System as a technical design for the creation and implementation of sanitary control programs in wholesale establishments of ornamental fish]. 2017. 202p. Tese (Doutorado em Ciências) - Faculdade de Medicina Veterinária e Zootecnia, Universidade de São Paulo, São Paulo, 2017.

Considerando a escassez de trabalhos científicos relacionados às medidas de biosseguridade na área de peixes ornamentais, o presente estudo utiliza o Sistema APPCC para delinear a criação e implementação de programas de autocontrole sanitário em estabelecimentos atacadistas de peixes ornamentais, estabelecendo os seguintes objetivos: 1) criar um guia de orientação para a adoção de medidas de biosseguridade relacionadas às boas práticas de manejo e higiene em comércio atacadista de peixes ornamentais; 2) listar os principais perigos biológicos de natureza bacteriana, viral, fúngica e parasitária aos quais os peixes ornamentais estão susceptíveis, bem como as medidas de prevenção e controle e 3) aplicar o Sistema APPCC em comércio atacadista de peixes ornamentais para um efetivo autocontrole sanitário dos animais comercializados. Como metodologia seguiram-se os passos para implementação do Sistema APPCC respectivamente: 1) identificação da empresa e definição do âmbito de aplicação, acompanhamento dos colaboradores e identificação das funções, das condições de infraestrutura e práticas higiênicossanitária, descrição do produto, elaboração de um fluxograma da área de processamento desde o recebimento até a expedição e validação "in loco" do Fluxograma; 2) identificação dos perigos biológicos e medidas preventivas para controle; 3) determinação dos pontos críticos de controle, estabelecimento de limites críticos de controle, monitoramento, ações corretivas; procedimentos de verificação e registro de dados e documentação. Conclui-se, que o Sistema APPCC é aplicável e útil para o autocontrole sanitário em comércio atacadista de peixes ornamentais e, como um programa de autocontrole serve de base para criação de outros programas relacionado às boas práticas, tais como controle higiênicossanitário e Bem Estar Animal, aumentando a qualidade técnicoprodutiva do negócio e oferecendo animais saudáveis ao consumidor.

Palavras chave: Peixes ornamentais. Sistema APPCC. Controle sanitário. Medicina veterinária preventiva. Programas de autocontrole. 


\begin{abstract}
CARDOSO, P.H.C. The HACCP System as a technical design for the creation and implementation of sanitary control programs in wholesale establishments of ornamental fish. [O Sistema APPCC como delineamento técnico para criação e implementação de programas de autocontrole sanitário em estabelecimentos atacadistas de peixes ornamentais]. 2017. 202p. Tese (Doutorado em Ciências) - Faculdade de Medicina Veterinária e Zootecnia, Universidade de São Paulo, São Paulo, 2017.

Due to the scarcity of scientific studies related to biosecurity measures in the ornamental fish area, this current study works under the HACCP System to delineate the creation and implementation of sanitary control programs in wholesale ornamental fish, establishing the following objectives: 1) to create a guideline for the implementation of biosecurity measures related to good management and hygiene practices in wholesale trade for ornamental fish;2) to list the main biological hazards of bacterial, viral, fungal and parasitic to which ornamental fish are susceptible, as well as the prevention and control measures; and 3) to apply the HACCP system in wholesale trade in ornamental fish for effective sanitary control of the sold animals. As a methodology, the following steps were taken in order to implement the HACCP System: 1) identification of the company and definition of the scope, monitoring of employees and identification of functions, infrastructure conditions and hygienic sanitary practices, product description, elaboration of a flow diagram from the processing area from receipt to expedition and on-site validation of the flow diagram; 2) identification of biological hazards and preventive measures for control; 3) determination of critical control points, establishment of critical limits of control, monitoring, corrective actions; procedures for verification and recording of data and documentation. It is concluded that the HACCP system is applicable and useful for sanitary self-control in wholesale trade in ornamental fish, and since a self-control program serves as a basis for the creation of other programs related to good practices such as hygienic sanitary control and Animal Welfare, increasing the technical-productive quality of the business and offering healthy animals to the costumer.
\end{abstract}

Key words: Ornamental fish. HACCP system. Sanitary control. Preventive veterinary medicine. Self-control programs. 


\section{LISTA DE QUADROS}

Quadro 1: Linha do tempo da empresa utilizada como cenário desde sua fundação ........................................ 26

Quadro 2: Resumo do plano APPCC

Quadro 3: Formulário para determinação do PCC1 para perigos de natureza bacteriana, viral, fúngica e parasitária na etapa de recebimento dos peixes ornamentais

Quadro 4: Formulário para determinação do PCC2 para perigos de natureza parasitaria na etapa de aclimatação

Quadro 5: Formulário para determinação do PCC3 para perigos de natureza bacteriana, viral, fúngica e parasitária na etapa de armazenamento dos peixes ornamentais

Quadro 6: Formulário para determinação do PC1 para perigos de natureza bacteriana, viral, fúngica e parasitária na etapa de captura dos peixes ornamentais

Quadro 7: Formulário para determinação do não PCC 2 e 3 para perigos de natureza bacteriana, viral, fúngica e parasitária na etapa de embalagem e distribuição dos peixes ornamentais 166

Quadro 8: Formulário dos Limites Críticos dos PCC 167

Quadro 9: Formulário com informações para o Monitoramento 168

Quadro 10: Formulário de ações corretivas 170 


\section{LISTA DE FIGURAS}

Figura 1: Planta baixa do estabelecimento utilizado como cenário, localizado na grande São Paulo

Figura 2 :Fluxo de entrada dos peixes ornamentais desde o recebimento até o armazenamento no estabelecimento utilizado como cenário, localizado na grande São Paulo.

Figura 3: Fluxo de venda ativa de peixes ornamentais desde a solicitação e recebimento do pedido de compra até a entrega para a distribuição da empresa utilizada como cenário, localizado na grande São Paulo.

Figura 4 - Organograma representativo do estabelecimento utilizado como cenário identificado por áreas e pessoas conforme legenda, localizada na grande São Paulo.

Figura 5 - Esquema representativo de sistema de Filtragem de Osmose Reversa da marca Express Water, com filtro de polipropileno (a), carvão ativado granular (b), carvão em bloco (c), membrana de RO (d) e carvão ativado granular (e).

Figura 6 - Exemplo de equipamento para mensuração do total de sólidos dissolvidos (TDS) da marca HM Digital Water, com filtro de polipropileno(a), carvão ativado granular (b), carvão em bloco (c), membrana de RO (d) e carvão ativado granular (e).

Figura 7: Etapas mínimas da higienização 38

Figura 8 - (a) Colaborador usando uniforme e EPI no manejo e peixes ornamentais; (b) colaborador sem uniforme e como vestimenta inadequada para o trabalho.

Figura 9: (a) Armazenamento de lixo inorgânico em saco plástico preto; (b) Armazenamento de lixo orgânico em saco plástico branco leitoso.

Figura 10: Exemplo esquemático de luz ultravioleta utilizada para tratamento de água em aquarismo. A água tratada entra contaminada (a) e sai tratada (b).

Figura 11 - Exemplo de Kit de pH da marca HM Digital®, com solução de calibração de pH (a), aparelho peagâmetro (b) e solução para estoque do eletrodo.

Figura 12 - Exemplo de ação executada pelo médico veterinário responsável técnico do estabelecimento utilizado como cenário com relação a animais doentes.

Figura 13: Representação gera dos grupos de animais comercializados na empresa utilizada como cenário, localizada na grande São Paulo.

Figura 14 -Representação de loja de varejo do setor de aquarismo do grupo Petz® em São Paulo

Figura 15 - Diagrama de fluxo da área de processamento do produto da entrada até a expedição e recomendações para cada etapa do processo 
Figura 16: (a) Peixes ornamentais na área de recebimento acondicionados em estrados impermeáveis e higienizados previamente ao recebimento; (b) Peixes ornamentais erroneamente em contato direto com o chão em área não exclusiva para o recebimento

Figura 17 - (a)Inspeção visual inicial ainda no recebimento para verificação das condições de saúde e bem estar dos peixes ornamentais; (b) Acondicionamento das embalagens com peixes aprovados na inspeção visual, sendo levados para área de armazenamento/estocagem 50

Figura 18 - (a) Aquário com uma única espécie (variedade) de peixe ornamental, devidamente identificado; (b) Exemplo de tabela em bateria de aquários com valores dos parâmetros de qualidade de água e registro das ações empregadas no monitoramento dos aquários 52 Figura 19 : (a) Inspeção visual das condições de saúde dos animais pelo Médico Veterinário; (b) Raspado de pele de peixe ornamental com sintomatologia clínica. Realização de exame microscópico e envio de material para diagnóstico laboratorial 53 Figura 20 - (a) Piranhas vermelhas (Pygocentrus natteri) apresentando nado irregular e movimentos de rodopio após terem sido alimentadas com alimento vivo. Posteriormente, foi diagnosticado a presença de Megalocitivirus sp; (b) Necrópsia de peixe ornamental doente para coleta de órgãos frescos para diagnóstico laboratorial

Figura 21: (a) Utensílios sem identificação; (b) Utensílios corretamente identificados, assegurando o uso individualizado por aquário ou bateria. 55

Figura 22: (a) Embalagem de peixes ornamentais em saco polietileno (saco plástico); (b) Identificação dos peixes ornamentais após embalagem. .56

Figura 23: (a) Após embalados e conferidos, peixes ornamentais são armazenados em caixas de poliestireno (isopor); (b) Caixa de poliestireno (isopor) lacradas e prontas para serem despachadas para o comércio varejista.

Figura 24: (a) Lesão de pele em Cyprinus carpio; (b),(c) lesão ocular em Carassius auratus; (d) sinais de septicemia em Carassius auratus 84

Figura 25: (a) Lesões arredondas com bordas avermelhadas em Polypterus senegalus; (b) bastonetes gram negativos do esfregaço das áreas lesionadas (aumento de 100X). 85 Figura 26: (a) Filtro de irradiação ultravioleta; e (b) aparelho gerador de ozônio, para tratamento de água de recirculação em aquários

Figura 27: (a) Piranhas vermelhas (Pygocentrus nattereri) letárgicas nadando em círculo; (b) foram submetidas a necropsia; (c) hiperemia dos vasos intestinais com sinais de hemorragia (microscopia 4x); (d) brânquias com hemorragias localizadas (microscopia 4x). 
Figura 28: (a) Lesão nodular esbranquiçada na nadadeira caudal de Chaetodon auriga; (b) Lâmina a fresco, vista microscópica (10x) de nódulos fibroblásticos na nadadeira caudal de Chaetodon auriga.

Figura 29: (a) Lesão algodonosa na superfície dorsal de Baryancistrus sp; (b) Lâmina corada com azul de algodão, vista microscópica (10x), presença de hifas, esporângios e zoospóros.94 Figura 30: (a) Doença dos pontos brancos causada por Ichthyophthirius multifilis no peixe ornamental Amphilophus trimaculatus; (b) Microscopia 20x. Parasita maduro com núcleo em forma de ferradura.

Figura 31: (a) Xiphophorus maculatus que se apresentava bastante debilitado e ofegante; (b) Microscopia aumento de 4x. Presença de metacercárias sugestivas de Centrocestus sp nas brânquias

Figura 32: (a) Polypterus palmas com monogêneas na pele e região ocular; (b) parasita no aumento microscópico de 4x, sugestivo de Gyrodactylus spp. 97 Figura 33: (a) Lerneae spp (seta) parasitando Xiphophorus hellerii; (b) Microscopia 4x. Ganchos em forma de âncora que se fixam na pele do peixe; (c) Argulus spp parasitanto Cyprinus carpio; (d) Microscopia 4x. Argulus spp.

Figura 34: (a) Doença dos pontos brancos causada por Cryptocaryon irritans no peixe ornamental Zebrassoma xanthurum; (b) Microscopia 40x, raspado de pele. Fase parasitária do protozoário (trofonte).

Figura 35: (a) Chromis viridis apresentando lesões ulcerativas hemorrágicas na pele; (b) \{cabeças de flechas\} presença de Uronema sp invadindo o tecido subcutâneo e o músculo esquelético; (c) \{ cabeça da seta \}protozoários invadindo o tecido branquial ; (c) \{asterisco\}com degeneração vacuolar, necrose e $\{$ flechas contínuas \}infiltrado inflamatório composto por granulócitos eosinofílicos; (d) \{cabeça da flecha\} parasitas invadindo a cápsula renal. Corado com hematoxilina-eosina (b-d). 101

Figura 36: (a) Pomacanthus semicirculatus com opacidade de ocular; (b) Microscopia 4x. Monogênea sugesttiovo de Neobenedenia melleni...... 102

Figura 37: Diagrama de fluxo com a representação dos PCC, PC e Não PCC após a utilização da árvore de decisão.

Figura 38: PCC 1 na etapa de recebimento dos peixes ornamentais .................................... 144

Figura 39: PCC 2 na etapa de aclimatação dos peixes ornamentais ....................................... 148

Figura 40: PCC 3 na etapa de armazenamento dos peixes ornamentais ............................... 151

Figura 41: PC na etapa de captura dos peixes ornamentais................................................ 154

Figura 42: Não há PCC nas etapas de Embalagem e Distribuição .......................................... 156 
Figura 43: Aparelho para medir o potencial de óxido redução (ORP) da água e verificar o correto funcionamento o aparelho de ozônio. 165

Figura 44: Teste da matéria orgânica na água dos aquários, após o tratamento com ozônio. 165 


\section{LISTA DE SÍMBOLOS E ABREVIATURAS}

\begin{tabular}{|c|c|}
\hline ANVISA & Agência Nacional de Vigilância Sanitária \\
\hline APPCC & Análise de Perigos e Pontos Críticos de Controle \\
\hline ARI & Análise de Risco de Importação \\
\hline $\mathrm{BP}$ & Boas práticas \\
\hline CRMV & Conselho Regional de Medicina Veterinária \\
\hline ECOAV & Empresa que Comercializa Organismos Aquáticos Vivos \\
\hline FAO & Food and Agriculture Organization \\
\hline FDA & Food and Drug Administration \\
\hline GMP & Good Manufacturing Practice \\
\hline HACCP & Hazard Analysis and Critical Control Point International \\
\hline IBAMA & Instituto Brasileiro do Meio Ambiente e dos Recursos Naturais Renováveis \\
\hline IBGE & Instituto Brasileiro de Geografia e Estatística \\
\hline IN & Instrução Normativa \\
\hline IT & Instruções de trabalho \\
\hline MAPA & Ministério da Agricultura Pecuária e Abastecimento \\
\hline MPA & Ministério da Pesca e Aquicultura \\
\hline OFI & Ornamental Fish International \\
\hline OIE & Oficina Internacional de Epizootias \\
\hline $\mathrm{OMC}$ & Organização Mundial do Comércio \\
\hline OMS & Organização Mundial da Saúde \\
\hline ORP & Potencial de Óxido Redução \\
\hline PAS & Programa de Autocontrole Sanitário \\
\hline $\mathrm{PCs}$ & Pontos de controle \\
\hline PCCs & Pontos críticos de controle \\
\hline PPHO & Procedimento Padrão de Higiene Operacional \\
\hline POP & Procedimento Operacional Padrão \\
\hline PVC & Policloreto de Vinila \\
\hline $\mathrm{RDC}$ & Resolução da Diretoria Colegiada \\
\hline $\mathrm{RO}$ & Reverso Osmose \\
\hline RT & Responsável Técnico \\
\hline SEAP & Secretaria Especial da Aquicultura e Pesca \\
\hline SIC & Serviço de Informação ao Cidadão \\
\hline SRA & Sistema de Recirculação de Água \\
\hline TDS & Total de Sólidos Dissolvidos \\
\hline UV & Ultra Violeta \\
\hline
\end{tabular}




\section{SUMÁRIO}

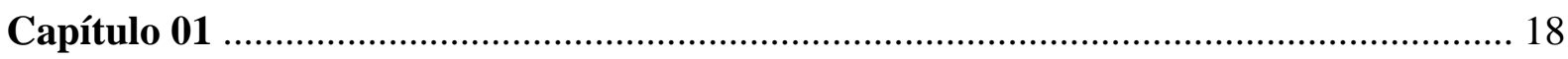

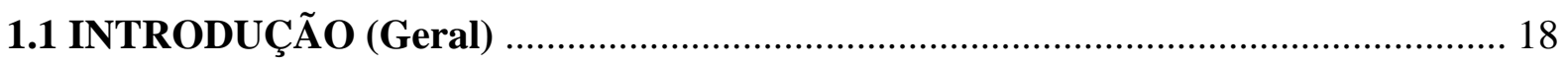

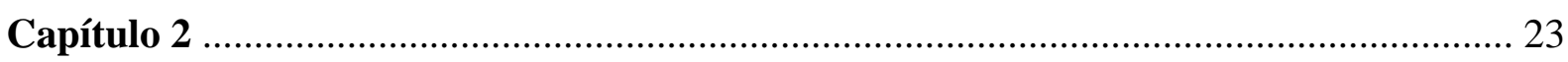

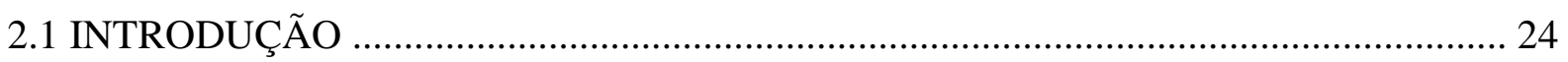

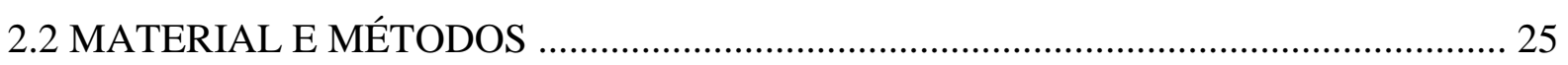

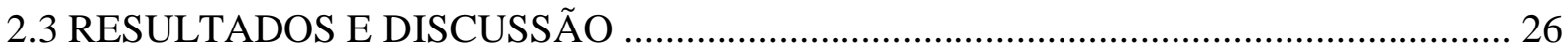

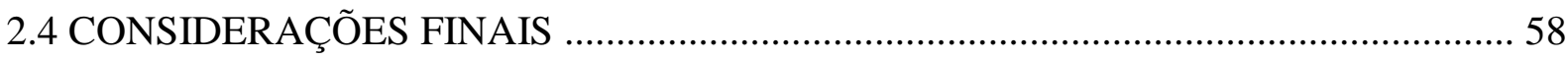

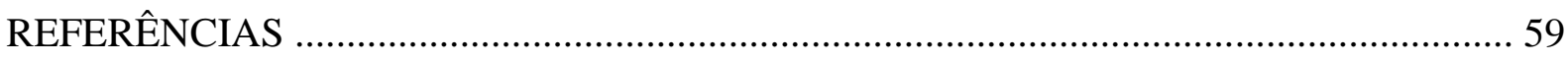

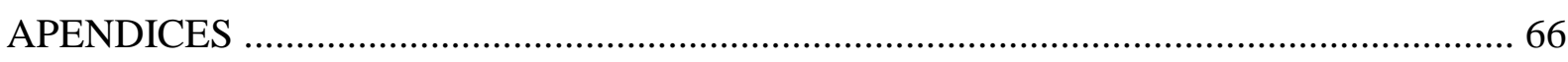

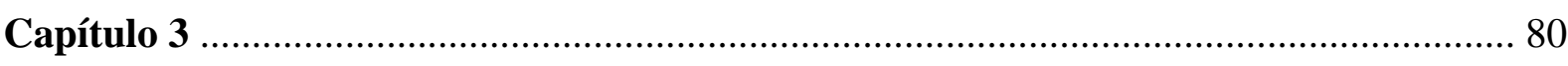

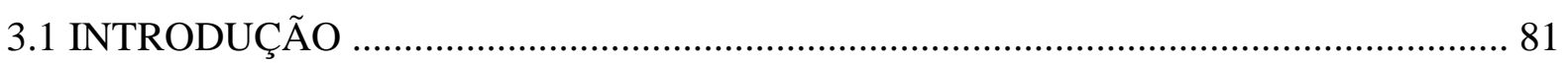

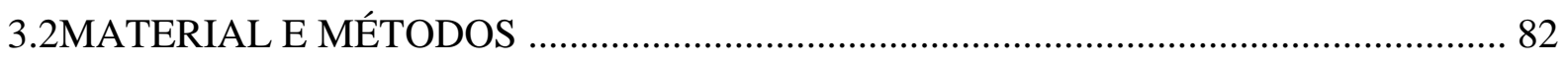

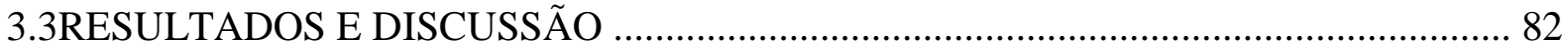

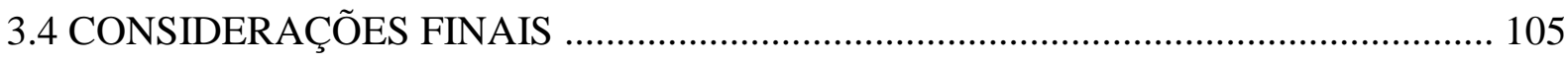

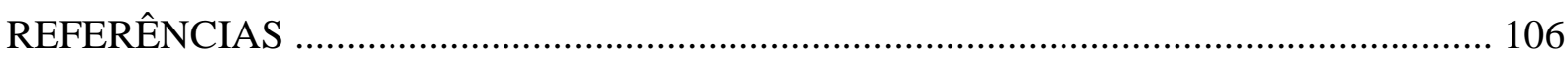

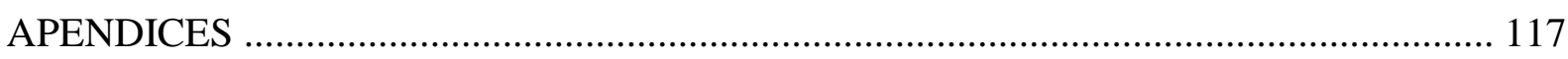

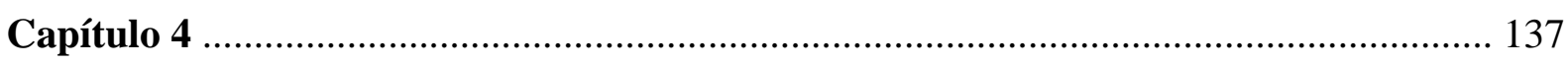

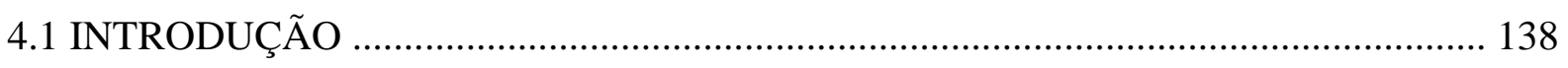

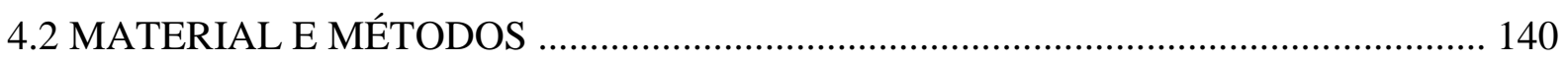

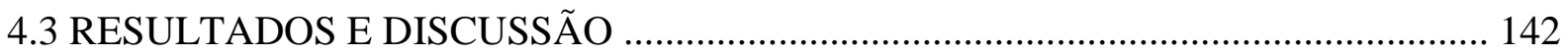

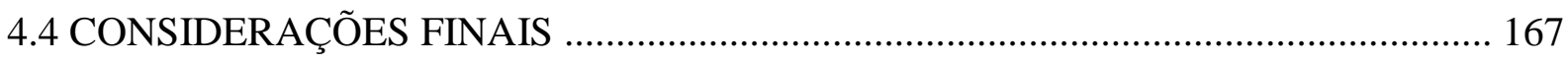

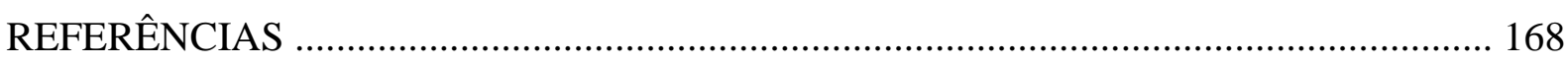

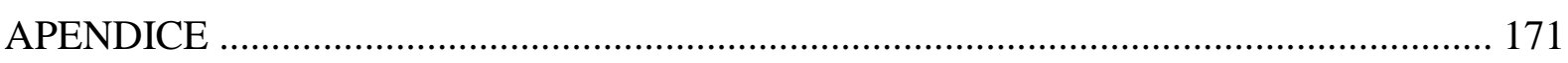

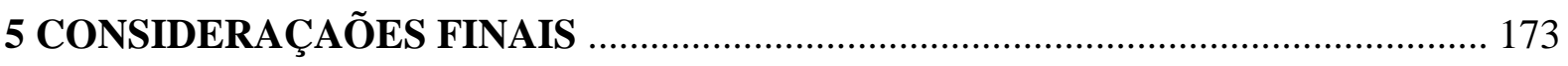




\section{Capítulo 01}

\subsection{INTRODUÇÃO (Geral)}

A aquariofilia é um grande segmento na indústria de animais de companhia no qual os Estados Unidos, a Europa e o Japão representam a maior expressividade no mercado (NOGA, 2010a). O Brasil ocupa o segundo lugar no mercado mundial para animais de estimação, e em 2016 movimentou 18,9 bilhões de reais. Segundo o IBGE os peixes são a terceira espécie de estimação mais prevalente nos domicílios brasileiros com cerca de 18 milhões segundo o último senso, ficando atrás apenas dos cães e gatos (ABINPET, 2017).

Em todo o mundo são aproximadamente 4 a 5 mil espécies de água doce (desse total cerca de $90 \%$ já são cultivadas) e mais de 1450 de água salgada, sendo a maioria extraídos da natureza (WHITTINGTON; CHONG, 2007). A maioria dos peixes ornamentais comercializados no Brasil são cultivados em fazendas de piscicultura. O estado de Minas Gerais é o maior produtor e abastece parte do mercado do Nordeste, Centro-Oeste, Sudeste e Sul (A. L. B. Magalhães and Jacobi, 2013). A Amazônia possui a maior diversidade de peixes ornamentais, predominantemente do extrativismo. O estado do Amazonas contribui com 93\% das exportações brasileiras, o que mostra ser uma importante atividade econômica que gera emprego e renda para uma parcela população (DANIEL et al., 2009).

Hoje a regulamentação da atividade de organismos aquáticos ornamentais no Brasil é de responsabilidade do IBAMA e do MAPA. O principal papel do IBAMA é estabelecer normas, critérios e padrões para exploração de peixes com finalidade. Já o principal papel do MAPA até a presente momento, diz respeito a sanidade dos organismo aquáticos, o que inclui de forma geral o acompanhamento da saúde dos animais (terrestres e aquáticos), fiscalização e monitoramento dos serviços utilizados nas atividades aquícolas, análise laboratorial como suporte às ações de defesa agropecuária, aquícola e pesqueira, certificação sanitária animal, registros de estabelecimentos aquícolas e ainda concessão à anuência para procedimentos para importação de animais vivos, independente da espécie (BRASIL, 2016).

Vale ressaltar que a regulamentação sanitária para animais aquáticos iniciou-se em 1999 com suspenção da importação de crustáceos, seus produtos e subprodutos em virtude de surtos da Doença da Mancha Branca e Doença da Cabeça Amarela em diversos países do mundo (BRASIL, 1999). Em 2003, foi aprovado o regulamento Técnico do Programa Nacional de Sanidade de Animais Aquáticos pelo MAPA. Após 2009, com a transformação da SEAP em MPA, a sanidade pesqueira e aquícola, antes incluída nas competências do MAPA como ramo implícito de defesa sanitária animal, passou a figurar o rol de atribuições ao MPA que desde 
então vinha determinando legislações relacionadas à sanidade dos organismos aquáticos. Em 2015, o MPA instituiu o Regulamento Técnico do Programa de Animais Aquáticos de cultivo que determina a aplicação de boas práticas relacionadas à aquicultura(BRASIL, 2015a). Porém em outubro 2015, houve a extinção do MPA devido a reforma ministerial do Governo da então presidente Dilma Rousseff. Todas as legislações criadas por este ministério foram revogadas e a sanidade voltou então para o MAPA.

O comércio e circulação de animais vivos sem o cumprimento de procedimentos técnicos padronizados e seguros possibilita a disseminação de inúmeros agentes causadores de doenças infecciosas e sérios problemas sanitários em regiões indenes, sem considerar que provocam situações estressantes aos animais levando a uma taxa de mortalidade e expressão de doenças totalmente evitáveis.

$\mathrm{O}$ aparecimento de doenças em virtude da falta de biosseguridade ${ }^{1}$, também restringem o desenvolvimento e a sustentabilidade de setores da aquicultura por perdas na produção e aumento nos custos operacionais e, indiretamente, através de restrições no comércio e impactos na biodiversidade.

Os programas de autocontrole são programas desenvolvidos, procedimentos descritos, implantados, monitorados e verificados pelo estabelecimento, com vistas a assegurar a inocuidade, a identidade, a qualidade e a integridade dos peixes ornamentais, que incluam, mas que não se limite aos programas de pré-requisitos, boas práticas e APPCC. A implementação de - Programas de Autocontrole Sanitário (PAS) durante a comercialização de peixes ornamentais é fundamental e vital para a sobrevivência do negócio e também para o equilíbrio sanitário e ecológico do setor(BRASIL, 2017).

A utilização de uma metodologia lógica, prática, e cientificamente fundamentada é necessária para que se possa estabelecer condutas e criar barreiras que garantam a prevenção e o controle de agravos ao sistema produtivo. O sistema de Análise de Perigos e Pontos Críticos de Controle - APPCC (Hazard Analysis and Critical Control Points - HACCP) adotado inicialmente em várias partes do mundo para garantir a produção de alimentos seguros é uma ferramenta bastante viável e seus conceitos podem ser utilizados em qualquer setor produtivo, inclusive de peixes ornamentais, de forma eficiente e eficaz para estruturar PAS. Como eixo central, o sistema APPCC compreende um conjunto de princípios para ação preventiva processo-específico, garantindo vários controles e ações corretivas ao longo do processo. É

\footnotetext{
${ }^{1}$ Em aquicultura biosseguridade é um termo que se refere às medidas aplicadas para reduzir a probabilidade da disseminação e impactos causados por agentes e organismos biológicos para um indivíduo, população ou ecossistema (FAO, 2010).
} 
um sistema lógico, prático, econômico e dinâmico. Como processo de controle transparente e confiável, constitui-se na ferramenta de gestão mais eficaz na obtenção de animais saudáveis, o que traz maior satisfação ao consumidor (CODEX ALIMENTARIUS COMMISSION, 2003).

Embora vários PAS baseados no sistema APPCC estejam bem firmados no setor de pescados processados para o consumo humano, a aplicação em estabelecimentos de aquicultura de consumo ainda se encontra em estágios iniciais (REILLY; KAFERSTEIN, 1997; TOOKWINAS; KEERATIVIRIYAPORN, 2004; ARVANITOYANNIS; VARZAKAS, 2008; YOUNG-MOK et al., 2012; MONDAL et al., 2013) e no sertor de peixes ornamentais é pouco conhecido. No entanto, o MAPA e órgãos regulatórios internacionais como OMS e FAO recomendam a implementação do sistema em todas as cadeias produtivas.

$\mathrm{Na}$ indústria dos peixes ornamentais, o controle de qualidade nos sistemas de produção, métodos de coleta, sistemas de transporte, armazenamento e embalagem, ainda apresentam muitas falhas que afetam o Bem Estar dos peixes ornamentais, levando a altas taxas de mortalidade e ocorrência de doenças, no Brasil e no mundo. No entanto muitos países europeus, vêm se tornando cada vez mais exigentes com questões relacionadas à qualidade e ao Bem Estar Animal, e a tendência é se tornarem ainda mais rigorosos com o passar dos anos.

A ausência de programas de controle de qualidade e medidas ambientais compatíveis nos processos de industrialização poderão ser fatais para indústria da região que sobrevive disso (comunicação pessoal Dr Geral Bassler) ${ }^{2}$. A Organização Internacional da Indústria de Peixes Ornamentais $(\mathrm{OFI})^{3}$, em seu livro de Biossegurança, recomenda a aplicação dos princípios do sistema APPCC para a elaboração de PAS, que identifica os pontos críticos em que o controle deve ser estratégico e essencial para reduzir a ocorrência de perigos que podem colocar em risco o sistema produtivo e de comercialização de peixes ornamentais (OFI, 2009).

Acredita-se que o sistema APPCC se aplica eficiente e eficazmente a este fim, sendo um valioso instrumento para a construção de PAS em casas atacadistas de peixes ornamentais. Após levantamento nas principais bases de dados PubMed, Scopus e Periódicos da Capes, no período de outubro de 2014 a agosto de 2015 pode-se perceber que não há na literatura nacional trabalhos relacionando PAS, sistema APPCC e peixes ornamentais, caracterizando o ineditismo da pesquisa. Dados sobre mortalidade e morbidade por doenças nos sistemas de produção dos organismos aquáticos com fins ornamentais, não existem no Brasil.

\footnotetext{
${ }^{2}$ Dr Gerald Bassler: Presidente da OFI, consultor e especialista em doenças de peixes ornamentais.

${ }^{3}$ OFI : Organização Mundial que representa todos os setores da indústria de peixes ornamentais
} 
Para facilitar o entendimento e tornar a leitura mais leve o autor dividiu a tese em Capítulos. Nos Capítulos adiante, o autor, fornecerá aos leitores as ferramentas necessárias (baseado no Sistema APPCC) para a criação de PAS em estabelecimentos atacadistas de peixes ornamentais, com o intuito de oferecer animais saudáveis aos consumidores. Cada Capítulo da tese é dependente um do outro e caso o empresário deseje implementar o Sistema APPCC e a criação de outros PAS em seu estabelecimento é necessário seguir as recomendações de cada um dos Capítulos.

O Capítulo 02 tem como objetivo fornecer aos leitores um guia para a adoção de medidas de biosseguridade relacionadas às boas práticas de manejo e higiene em estabelecimentos comerciais atacadistas de peixes ornamentais, como parte do processo de construção de PAS, e usa o sistema APPCC como propósito. As recomendações listadas no Capítulo são requisitos obrigatórios para a construção de programas de autocontrole sanitário relacionados às boas práticas, controle higienico sanitário e de processos e Bem Estar Animal que por sua vez é um pré-requisito obrigatório para aqueles que almejam implementar o Sistema APPCC em seus estabelecimentos. O guia foi contruído pelo autor com base em sua vivência prática em um estabelecimento utilizado como cenário. Para a construção do guia foi considerado as áreas da empresa que diretamente estão relacionadas aos animais, o organograma da empresa de acordo com as áreas e funções dos colaboradores, assim como as condições de infraestrutura e práticas higiênicossanitárias. Foi considerado todas as ações executadas pelos colaboradores desde o recebimento até a expedição dos animais. Todas as sugestões listadas pelo autor estão apoiadas em literatura científica.

O Capítulo 03 tem com objetivo listar os principais perigos biológicos de natureza bacteriana, viral, fúngica e parasitária ao qual os peixes ornamentais estão susceptíveis, bem como as medidas de prevenção e controle para eliminar e reduzi-los a níveis aceitáveis. Os perigos relacinados no Capítulo 03 são baseados no histórico de diagnóstico feito pelo Médico Veterinário Responsável Técnico do estabelecimento utilizado como cenário, com apoio laboratorial e corroborado com a literatura científica. O número de perigos de natureza biológica é amplo e merece atenção pois podem ser prejudiciais tanto para os peixes quanto para aqueles que os manipulam caso boas práticas de manejo não seja corretamente empregadas.

E por fim o Capítulo 04 estabelece pontos críticos de controle nas etapas ditas como realmente críticas (de acordo com a árvore decisória) e medidas preventivas para o controle dos principais perigos biológicos que acometem os peixes ornamentais e tem como objetivo 
aplicar o sistema APPCC em comércio atacadista de peixes ornamentais para um efetivo autocontrole sanitário dos animais comercializados. 


\section{Capítulo 2}

Guia para a adoção de medidas de biosseguridade relacionadas às boas práticas de manejo e higiene em comércios atacadistas de peixes ornamentais 


\subsection{INTRODUÇÃO}

O aquarismo é um dos hobbies mais populares do mundo. Os avanços na criação de peixes ornamentais e tecnologia dos equipamentos utilizados nos aquários nos últimos anos facilitou a manutenção e simplificação dos mesmos, o que contribuiu para o crescimento da popularidade. Embora a maioria dos peixes ornamentais comercializados sejam de água doce, peixes de água salgada também vem ganhando popularidade depois da exibição de filmes como "Procurando Nemo" e "Procurando Dory" (Disney- Pixar@) e outros programas de televisão, principalmente devido suas cores vivas e exuberantes(E.J; CHAPMAN, 2014).

Os atores envolvidos na comercialização envolvem produtores primários (piscicultores e pescadores extrativistas), atravessadores (adquirem animais dos produtores primários), distribuidores (importadores, exportadores e atacadistas), varejistas e por fim o consumidor final (hobbysta)(ANATOLE; BOSCH, 2008).

Os distribuidores de peixes ornamentais no Brasil podem receber peixes de diferentes regiões do território nacional e do mundo, desde que devidamente legalizados conforme requisitos do IBAMA e MAPA (BRASIL, 2008a, 2008b, 2011, 2012). São cerca de 1500 espécies de água salgada (maioria obtida da pesca extrativa) e mais de 4500 de água doce (quase $100 \%$ já são criados em cativeiro)(WHITTINGTON; CHONG, 2007).

A translocação de animais aquáticos possibilitou que peixes ornamentais de diferentes regiões do mundo pudessem ser criados em certas regiões do território brasileiro, alguns inclusive possuem alta taxa de reprodução devido ao clima favorável. No entanto, peixes ornamentais podem trazer consigo "caronas" indesejáveis não perceptíveis a olho nu, de natureza bacteriana, viral, fúngica e parasitária (OATA, 2006), sendo alguns desses agentes, causadores de doenças bacterianas de caráter zoonótico, colocando em risco aqueles que manipulam os animais (BERAN et al., 2006; LOWRY; SMITH, 2007; WEIR et al., 2012; FULDE; VALENTIN-WEIGAND, 2013; GAUTHIER, 2015).

Dessa forma, este guia oferece orientações técnicas e sugestões para a adoção de medidas de biosseguridade relacionadas às boas práticas de manejo e higiene na aquicultura, como parte do processo de construção de programas de autocontrole higiênicossanitário em estabelecimentos comerciais de peixes ornamentais (principalmente distribuidores atacadistas).

A adoção de boas práticas de manejo e higiene é fundamental para proteger os organismos aquáticos ornamentais de contrair, carrear ou disseminar doenças, permitindo o autocontrole 
da comercialização por parte dos empreendedores de estabelecimentos para os elos seguintes da cadeia.

Para aqueles estabelecimentos que almejam adotar programas de qualidade como o sistema APPCC, o presente documento é um guia para o cumprimento dos pré-requisitos prévios para a implementação.

\subsection{MATERIAL E MÉTODOS}

Para o cumprimento do objetivo já mencionado no Capítulo 01 foi utilizado como cenário um estabelecimento distribuidor (modalidade atacadista) de peixes ornamentais localizado na Grande São Paulo, e foi conduzido da seguinte forma:

\subsubsection{Identificação da empresa e definição do âmbito de aplicação das boas práticas relacionadas aos peixes ornamentais}

Para elaborar o guia de boas práticas de manejo e higiene a empresa foi identificada e em seguida definido o âmbito de aplicação do plano de programa de boas práticas de manejo e higiene. O limite do plano também foi definido.

\subsubsection{Acompanhamento dos colaboradores e identificação das funções}

Os colaboradores que operam no estabelecimento foram acompanhados por um período de três meses, para o correto conhecimento da metodologia empregada com relação ao manejo dos animais desde o recebimento até a embalagem para distribuição. Os colaboradores foram alocados em organograma e as funções determinadas de acordo com a atividade exercida.

\subsubsection{Condições de infraestrutura e práticas higiênico sanitárias}

Após o entendimento das metodologias adotadas pela empresa foi sugerido propostas genéricas para a aplicação de procedimentos relacionado às boas práticas de manejo e higiene com o intuito de diminuir a possibilidade de introdução e/ou disseminação de doenças no estabelecimento e preservar o "status" sanitário dos animais comercializados, de modo a oferecer animais sem risco de doenças para os consumidores.

As sugestões propostas foram embasadas em literatura científica e experiência do autor que desde 2009 está envolvido com o ramo de aquariofilia.

Foram criados check lists (Apêndice 1 e 2) para serem aplicados em diversas etapas dos processos ao qual os animais estão envolvidos, além de sugestões para condições mínimas de 
infraestrutura e práticas higienicossanitárias com relação às edificações, instalações, equipamentos e utensílios e a implementação de um controle de qualidade baseado em oito Procedimentos Operacionais Padrão (POPs).

\subsubsection{Descrição do produto (organismos aquáticos ornamentais)}

Foi reunido conhecimento geral sobre o processo e o produto a ser comercializado, desde a chegada até a saída da empresa. Essas informações dizem respeito ao tipo de animal comercializado, características ambientais naturais, disposição nos aquários, condições para armazenamento (parâmetros da água), forma de embalagem, cuidados gerais a serem tomados, entre outras características peculiares do produto.

\subsubsection{Identificação do uso pretendido do produto e seus consumidores}

Os potenciais consumidores do produto foram identificados.

\subsubsection{Elaboração de um fluxograma e esquema da área de processamento desde o recebimento até o transporte}

Foi elaborado um fluxograma legível de fácil compreensão que inclui todos os passos do processo em sequência desde o recebimento até o transporte dos animais. Cada ponto do processo foi considerado em detalhe e a informação alargada de forma a incluir todos os dados tecnicamente relevantes de cada etapa.

\subsubsection{Validação "in loco" do Diagrama de Fluxo}

A validação das descrições teóricas foi efetuada confrontando-se as etapas do fluxograma que foram descritas com as operações realizadas no dia a dia. Foi observado o processo em todos os períodos operacionais, permitindo-se fazer os ajustes necessários e assegurar que o fluxograma é válido. Nesta fase foram observados fatores considerados importantes para a implementação do plano APPCC, tais como: situação e condições das edificações, equipamentos, instrumentos e utensílios, treinamento do pessoal, qualidade dos animais comercializados, fluxo de trabalho, controle de qualidade do produto, controle integrado de pragas, escolha de fornecedores, manual de boas práticas.

\subsection{RESULTADOS E DISCUSSÃO}

\subsection{1 Âmbito de aplicação do guia de boas práticas}


O cenário utilizado para a elaboração do guia de boas práticas foi um distribuidor (modalidade atacadista) localizado na grande São Paulo.

\subsubsection{Planta baixa do estabelecimento (figura 1)}

Para que um distribuidor de peixes ornamentais possa confeccionar seu manual de boas práticas, é necessário, primeiramente, providenciar uma planta baixa com todas as áreas da empresa. A análise da planta já permitirá verificar se existe uma lógica linear no fluxo de processo. Caso isso não ocorra, é importante que seja estabelecido, para que se possa assegurar diversas outras práticas seguras.

Figura 1: Planta baixa do estabelecimento utilizado como cenário, localizado na grande São Paulo

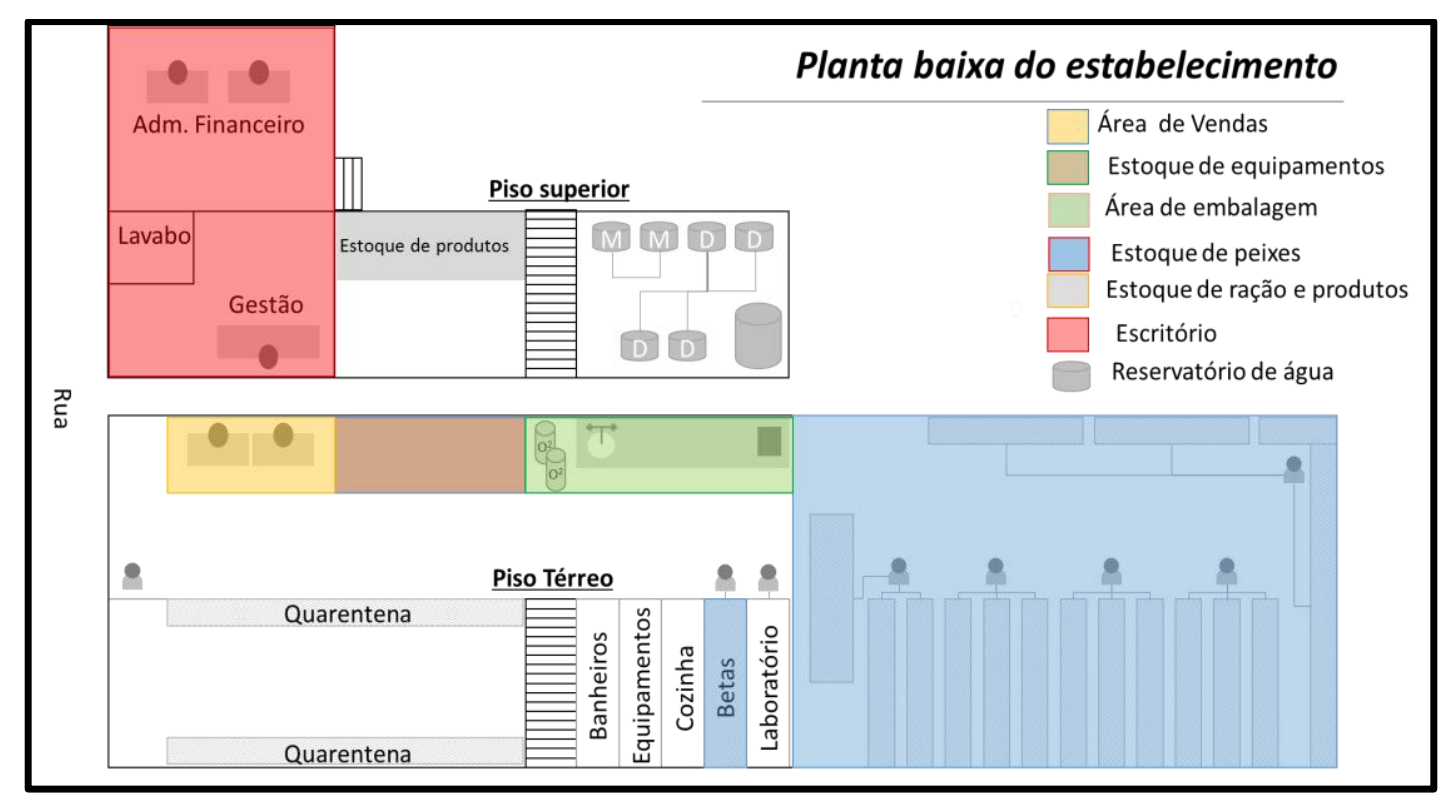

Fonte: Cardoso, 2016

\subsubsection{Linha do tempo desde a fundação da empresa (quadro 1)}

A empresa deve criar uma linha histórica de registros, isto é, uma linha do tempo, documentando todas as ocorrências relativas aos processos ali realizados. Pelo menos uma vez ao ano, deve revisar e atualizar todos os seus procedimentos ou quando houver qualquer alteração ou necessidade de modificações. Para isso deve criar uma agenda e planificar as atividades ao longo do tempo. 
Quadro 11: Linha do tempo da empresa utilizada como cenário desde sua fundação

\begin{tabular}{|c|c|}
\hline Ano & Acontecimento \\
\hline 2001 & $\begin{array}{l}\checkmark \text { Início da atividade de maneira informal. O proprietário monta uma estrutura com } \\
\text { aquários em casa e sai diariamente vendendo espécies de peixes ornamentais } \\
\text { mais comuns de loja em loja. }\end{array}$ \\
\hline 2002 & $\begin{array}{ll}\checkmark & \text { Abertura do CNPJ e primeira mudança para uma estrutura física maior. } \\
\checkmark & \text { Contrata o primeiro funcionário, amplia a variedade de peixes comercializados. }\end{array}$ \\
\hline 2008 & $\begin{array}{ll}\checkmark & \text { Inicia o processo para o credenciamento de quarentenário para importação de } \\
& \text { peixes ornamentais. } \\
\checkmark & \text { Cadastramento no CRMV/SP. }\end{array}$ \\
\hline 2009 & $\begin{array}{ll}\checkmark & \text { Credenciamento do quarentenário pelo MAPA. } \\
\checkmark & \text { No final do ano, realizou a primeira importação. }\end{array}$ \\
\hline 2012 & $\begin{array}{l}\checkmark \quad \text { Segunda mudança da empresa para um novo galpão com mais espaço e maior } \\
\text { número de aquários. } \\
\checkmark \quad \text { Início da construção de nova estrutura que futuramente seria o novo } \\
\text { quarentenário credenciado da empresa. } \\
\checkmark \quad \text { A gestão administrativa da empresa inicia a procura por técnicos na área. }\end{array}$ \\
\hline 2013 & $\checkmark \quad$ Início do trabalho com médico veterinário prestando assessoria técnica. \\
\hline 2014 & $\checkmark$ Credenciamento do segundo quarentenário pelo MPA. \\
\hline
\end{tabular}

Fonte: Cardoso, 2016

\subsubsection{Delimitação da área de aplicação do guia}

A elaboração do guia de boas práticas para a construção do manual de boas práticas diz respeito ao setor produtivo do estabelecimento. Área única e diretamente ligada ao manejo dos animais, que compreende a manutenção e estoque, desde o recebimento até entrega dos animais para transporte (figura 2 e figura 3 ). 
Figura 2 :Fluxo de entrada dos peixes ornamentais desde o recebimento até o armazenamento no estabelecimento utilizado como cenário, localizado na grande São Paulo.

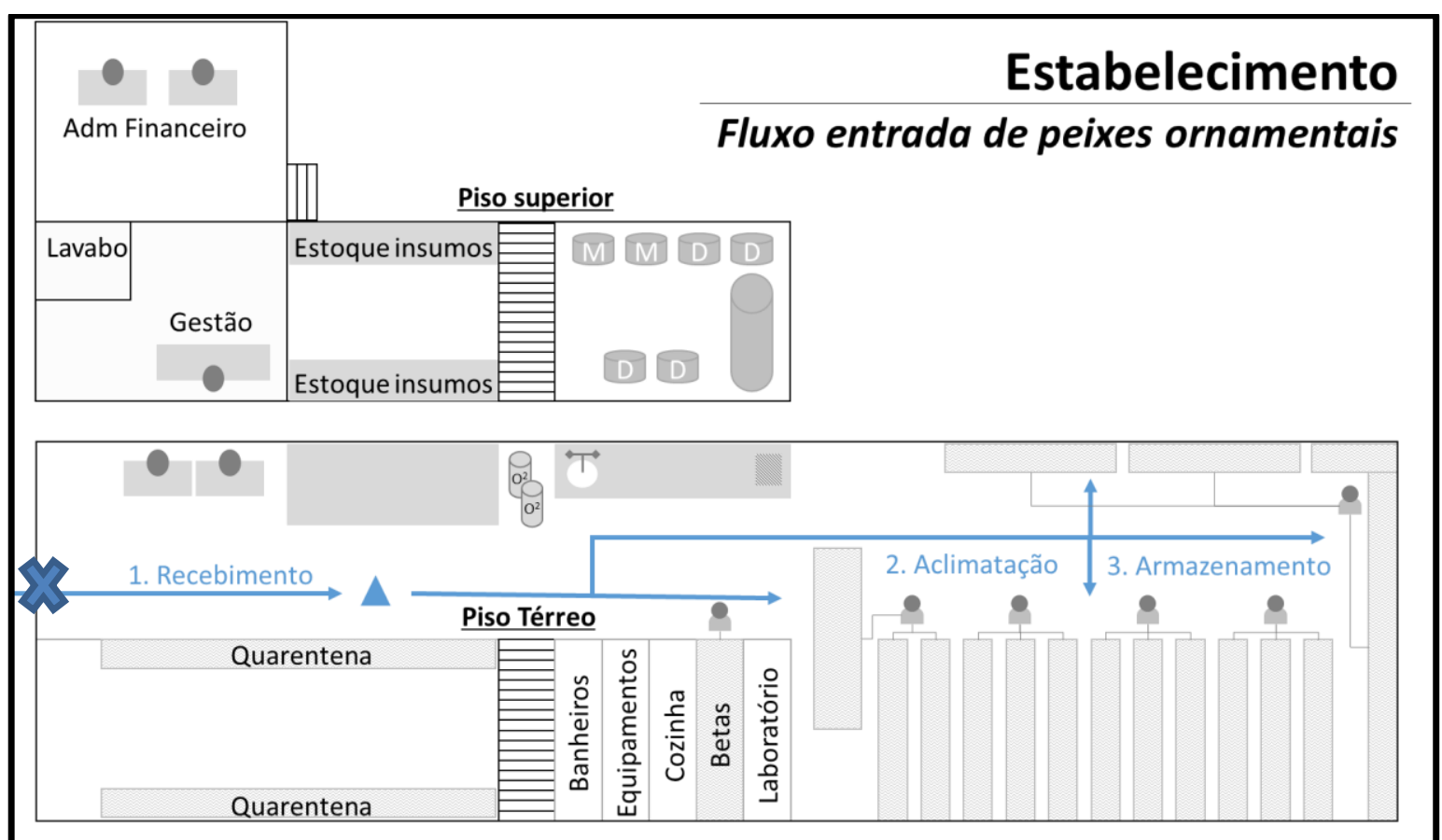

Fonte: Cardoso, 2016

Figura 3: Fluxo de venda ativa de peixes ornamentais desde a solicitação e recebimento do pedido de compra até a entrega para a distribuição da empresa utilizada como cenário, localizado na grande São Paulo.

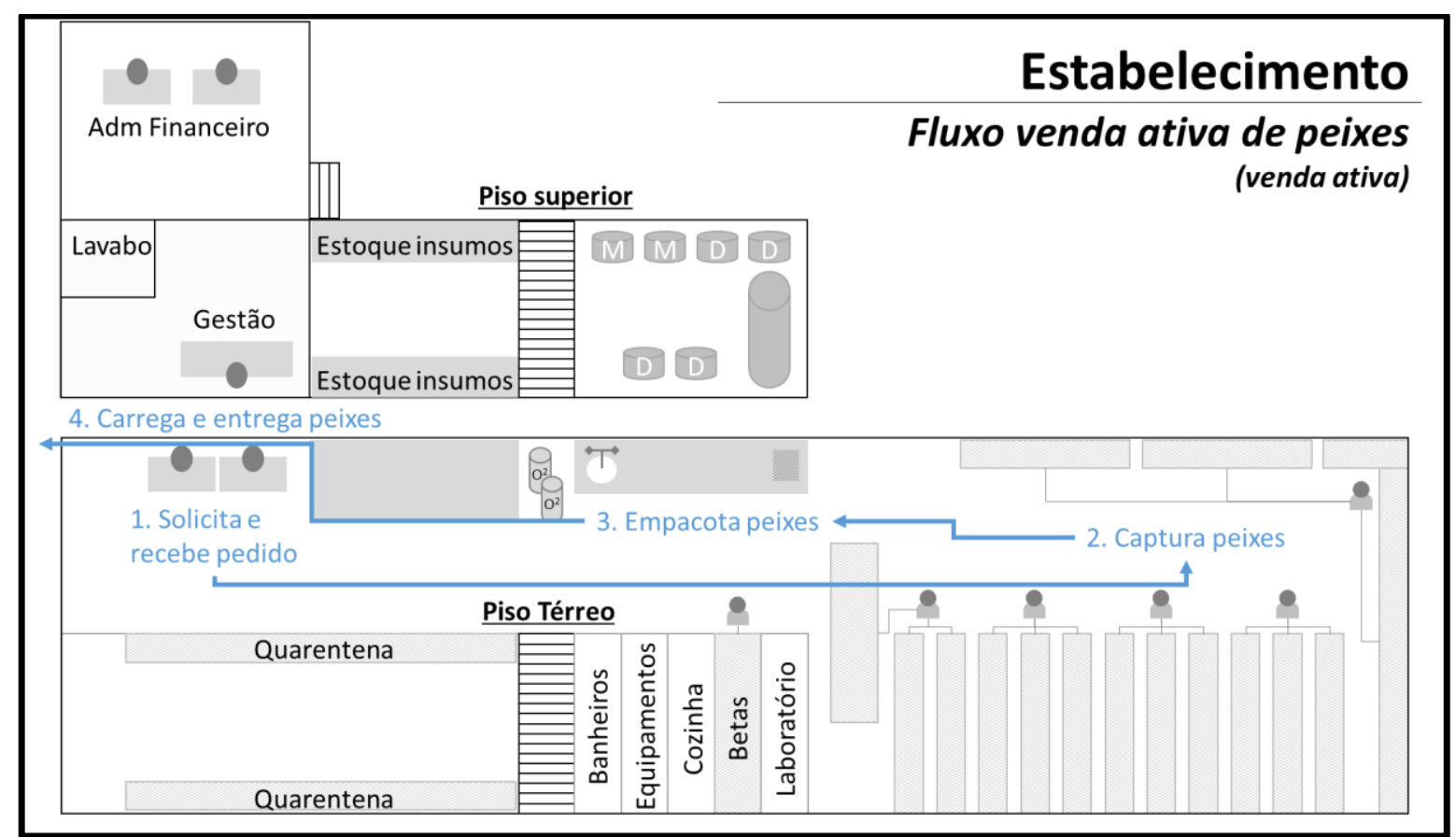

Fonte: Cardoso, 2016 


\subsubsection{Organograma da empresa de acordo com áreas e funções dos colaboradores}

Para melhor organização e gestão do estabelecimento é necessário criar um organograma representando as diferentes áreas (figura 4). No manual devem ser descritas as áreas, as pessoas que atuam em cada uma delas e suas atribuições de trabalho.

Figura 4 - Organograma representativo do estabelecimento utilizado como cenário identificado por áreas e pessoas conforme legenda, localizada na grande São Paulo.

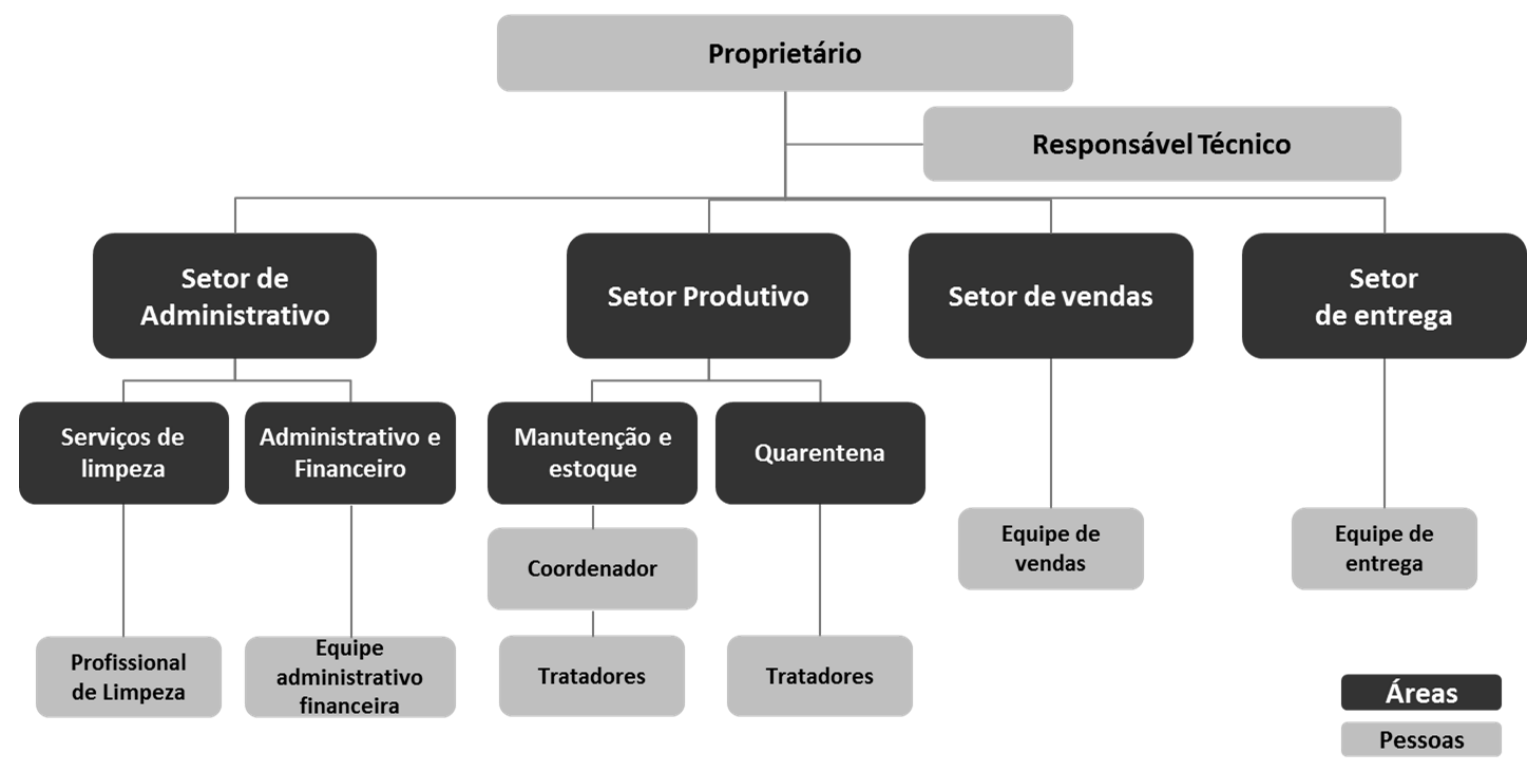

Fonte: Cardoso, 2016

\subsubsection{Condições de infraestrutura e práticas higienicossanitárias}

Os estabelecimentos comerciais de peixes ornamentais devem obedecer a condições mínimas com relação a infraestrutura e práticas higiênico sanitárias com o intuito de minimizar situações de risco da introdução e/ou disseminação de agentes patogênicos e também de facilitar práticas higiênicas no âmbito geral (BRASIL, 2003, 2015a). Apenas os estabelecimento credenciados para importação possuem regulamentação própria quanto as condições de infraestrutura mínima, quadro funcional, controle de circulação de pessoas e procedimento de registro sanitário (BRASIL, 2008a), porém é importante que todos os estabelecimento de aquicultura adotem tais medidas, como proposto pelo MPA em 2016 no Programa Aquicultura com Sanidade (BRASIL, 2015a). 


\subsubsection{Edificações}

É de extrema importância durante a etapa de planejamento físico a participação de profissionais experientes na área de administração e operacionalização das atividades em estabelecimentos comerciais de peixes ornamentais. Ao construir ou reformar as edificações do setor produtivo e áreas adjacentes, o dimensionamento da área e a especificação dos equipamentos devem ser definidos com base nas necessidades da organização e fluxos de processos (BERTINI; MENDES., 2011)(FOSSA et al., 2009).

Recomenda-se que a planta física seja de construção sólida e que os materiais sejam todos com qualidade sanitária preferencialmente impermeáveis, de fácil higienização, manutenção e de baixo risco do acúmulo de sujidades e de formação de biofilmes microbianos(BRASIL, 2008c; FOSSA et al., 2009) tais como materiais de aço inoxidável, acrílico, vidro, pvc , entre outros. Deve-se garantir o fluxo ordenado e lógico desde o recebimento até o transporte e expedição, de forma que sua trajetória seja linear (recebimento-armazenamento-capturaembalagem-transporte-expedição), facilitando os trabalhos dentro do setor produtivo(ALMEIDA et al., 2005).

Todo estabelecimento que cria e/ou comercializa animais aquáticos com fins comerciais deve estar legalmente habilitado pelos órgãos competentes quanto aos documentos de autorização de funcionamento(BRASIL, 2015a). No estado de São Paulo esses órgãos incluem CRMV, MAPA, IBAMA e Secretaria Estadual de Defesa Agropecuária. Lembrando que cada estado pode ter legislações que diferem no que diz respeito a essas autorizações.

O laytout deve prever a separação física e funcional das áreas de trabalho de acordo com as características de cada setor (figura 1). Devem existir áreas distintas para recebimento, armazenamento e embalagem. Setores como banheiros, depósitos de resíduos, casa de máquinas devem estar o mais distante possível dos setores produtivos. É indispensável o escoamento eficiente de águas residuais com proteção contra pragas advindas das tubulações de esgoto(ALMEIDA et al., 2005).

Uma área especifica deve ser destinada à higienização de equipamentos e utensílios. Após higienizados, tais equipamentos e utensílios devem ser mantidos limpos e secos em locais apropriados e protegido de contaminações para que estejam prontos para o uso no início do próximo expediente(ALMEIDA et al., 2005; BRASIL, 2008c, 2015a). 


\subsubsection{Instalações}

As instalações devem ser seguras e garantir que haja o menor risco possível de contaminações, contaminações cruzadas e situações que possam comprometer a saúde das pessoas e dos animais ali presentes(SILVA JUNIOR, 2014) conforme sugerido adiante.

\section{Orientações sugeridas para as Instalações}

\section{a) Pisos, ralos e canaletas}

Os pisos devem ser de material que permita a fácil e apropriada higienização, ou seja, impermeáveis, lisos, com características antiderrapantes e drenados em direção aos ralos e canaletas.

O sistema de drenagem deve ser dimensionado de modo que não haja acúmulo de refluxo ou drenagem.

Os ralos devem ser sifonados e possuir tampos dotados de sistema de fechamento que impeça a entrada de pragas advindas da tubulação, além de impedir a entrada de resíduos sólidos para evitar entupimentos e mau odor no ambiente.

As canaletas devem cumprir a mesma exigência dos ralos, além de precisar ser inteiramente revestidas com material que as torne lisa, para evitar o acúmulo de resíduos e facilitar a limpeza.

\section{b) Tetos e forros de proteção}

O estabelecimento deve ser fechado e protegido para que não haja entrada de animais sinantrópicos e pragas e quando aplicável devem ter teto liso, impermeável, lavável e de cor clara.

\section{c) Bancada para embalagem de animais}

As bancadas para embalagem devem ser de material liso, lavável, resistente e impermeável de modo a facilitar a fácil manipulação e higienização.

\section{d) Instalações elétricas}

As instalações elétricas devem ser embutidas nas paredes. Quando forem externas, precisam ser revestidas por tubulações isolantes e presas a paredes e tetos. A iluminação pode ser artificial (aquários) ou natural (outras áreas), adequada à atividade desenvolvida, sem ofuscamento.

\section{e) Ventilação e exaustão}

A ventilação e a circulação de ar devem proporcionar conforto térmico e renovação do ar no ambiente. O mecanismo de ventilação/exaustão pode ser natural ou mecânico. No entanto o sistema de ventilação deve ser projetado e construído de forma que o ar não circule de um aquário/bateria para outro já que muitos patógenos podem ser transmitidos através de aerossóis(YANONG, 2009a).

\section{f) Aquários/Bateria de aquários}

Os aquários/baterias de aquários devem ser construídos em tamanho suficiente a não estressar os animais por falta de espaço, principalmente em estabelecimentos atacadistas que recebem alto volume de animais semanalmente e requer bastante espaço. Preferencialmente com vidro resistente e de fácil visualização do ambiente interno.

O sistema de filtragem mecânica e biológica deve ser eficiente para remoção de partículas grosseiras e o tamanho compatível com o volume e densidade de animais alojados, para manter os padrões de qualidade de água, que deve chegar no sistema de filtragem de tratamento (ozônio ou luz ultravioleta) límpida(TANGO; GAGNON, 2003; KUBITZA, 2006; SHARRER; SUMMERFELT, 2007). 


\subsubsection{Equipamentos e utensílios}

Os equipamentos e utensílios utilizados no manejo dos animais devem ser compostos de material que garanta limpeza, desinfecção e manutenção adequados. As superfícies devem ser lisas, impermeáveis, com bordas arredondas para que não haja o acúmulo de resíduos(ALMEIDA et al., 2005).

É necessário que o empreendimento tenha gerador próprio para manter os equipamentos que dependam de eletricidade em constante funcionamento nos aquários em caso de pane elétrica, o que garante o correto funcionamento do sistema(OATA, 2006).

\section{Orientação para o correto funcionamento dos Equipamentos e Utensílios}

I) Bombas de circulação, aquecedores, termostatos devem ser monitoradas diariamente (pelo menos duas vezes ao dia) para verificar o correto funcionamento. A manutenção desses aparelhos deverá ser periódica para garantir o correto funcionamento e segurança dos animais nele alojados;

II) Sacos de polietileno (sacos plásticos) utilizados para embalagem e transporte de peixes ornamentais devem ser resistentes, transparentes e isentos de contaminantes. Jamais fazer reciclagem de embalagens;

III) Caixas de poliestireno (caixas de isopor) utilizadas para acondicionamento e transporte dos animais devem ser resistentes, higienizadas e preferencialmente de cor branca;

IV) Pinças, redes, canecas, baldes e outros utensílios utilizados na manipulação e manejo dos animais devem ser corretamente higienizados logo após a utilização com produto devidamente regulamentado para uso em estabelecimentos de aquicultura;

V) Aparelhos que são utilizados para medir a qualidade de água como peagâmetro, termômetro, e outros devem ser devidamente calibrados a cada uso ou de acordo com a recomendação do fabricante;

VI) Testes químicos para avaliar parâmetros de qualidade de água devem ser utilizados de acordo com as orientações do fabricante. Preferencialmente utilizar um único teste de mesmo fabricante pois pode haver variação nos valores de referência entre uma marca e outra. O ideal é utilizar a marca mais confiável disponível no mercado;

\subsubsection{Controle de qualidade}

Para que os estabelecimentos cumpram programas de boas práticas de manejo e higiene, deve-se implementar um programa de controle de qualidade de todo o processo, o qual dependerá de supervisão e atualizações periódicas, no mínimo anuais (SILVA JUNIOR, 2014). O supervisor pode ser o proprietário ou outro profissional devidamente habilitado (responsável técnico - RT).

Primeiramente deve-se estabelecer uma equipe de boas práticas para facilitar a efetiva implementação do programa. Inicialmente o supervisor capacitará a equipe para que compreenda a importância do programa, compreenda suas definições e a importância do trabalho desempenhado por cada um dos colaboradores envolvidos no processo(SENAC, 
2001). Caberá ao supervisor, identificar as capacidades, habilidades, conhecimento e disposição de cada trabalhador, definindo as funções e tarefas a cada um deles(BERTINI; MENDES., 2011).

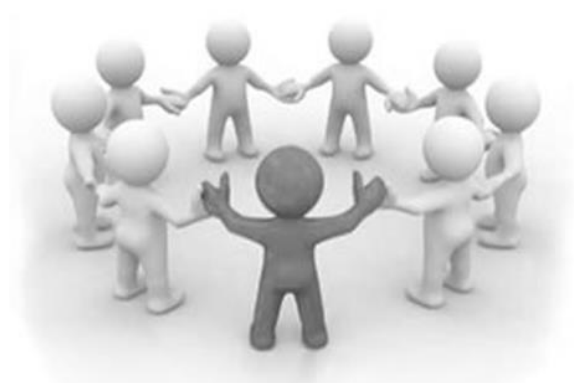

É necessário que se monte uma equipe de boas práticas

É também atribuição do supervisor elaborar e atualizar o Manual de Boas Práticas da empresa, garantir monitoramento dos procedimentos e determinar as ações corretivas perante não conformidade de procedimentos durante os processos. O supervisor deve ser responsável pela programação de treinamentos, incluindo coleta de amostras de animais para diagnóstico laboratorial, como será mencionado adiante.

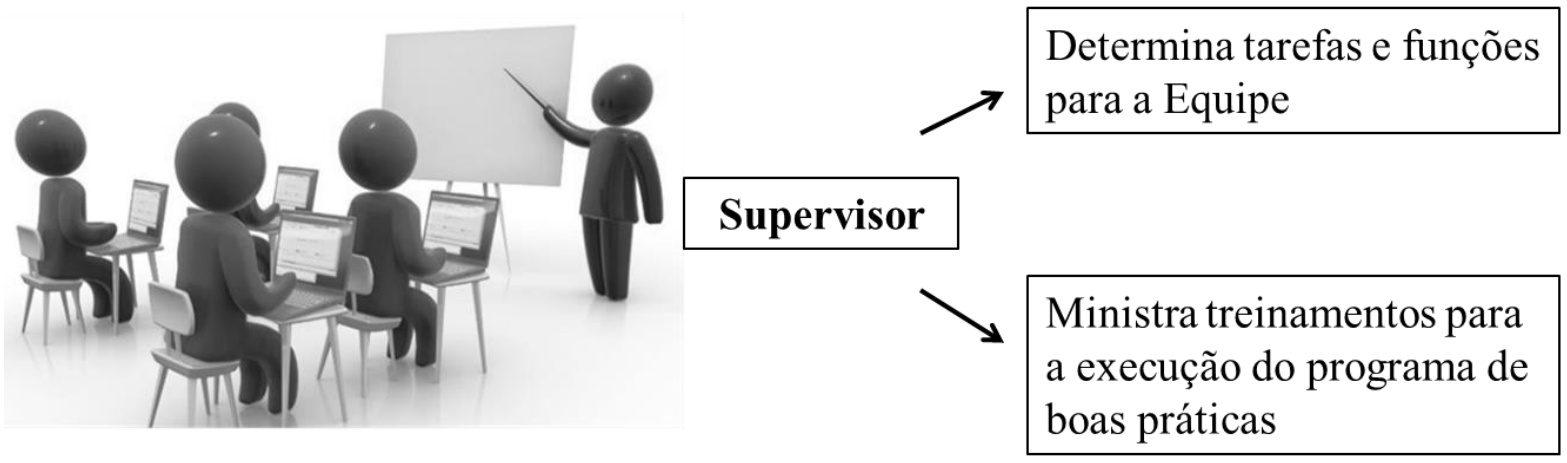

Para dar início ao Programa de Boas práticas, sugere-se implementar oito Procedimentos Operacionais Padronizados (POP) referentes a segurança higienicossanitária do estabelecimento. Devem ser criadas instruções de trabalho (IT) para facilitar a sua execução, nas diferentes áreas e setores, mantidas em fácil acesso para constante consulta dos trabalhadores(BERTINI; MENDES., 2011).

Abaixo estão descritos, de forma detalhada, cada um dos oito POPs sugeridos para estabelecimentos atacadistas de peixes ornamentais, inspirados em guias da área de segurança alimentar, sendo perfeitamente aplicável desde que devidamente ajustado:

\section{- POP 1 Controle da qualidade da água}

Á água que abastece o estabelecimento e que terá como destino os aquários para alojamento dos peixes ornamentais deve ser captada de fonte segura(BRASIL, 2008c, 2015a). Para 
aquários de água doce, recomenda-se que antes de entrar nos reservatórios a água passe por um sistema de filtragem (pelo menos filtro de polipropileno e carvão ativado) para a retirada de agentes indesejáveis que possam estar presentes na água(KENT et al., 2009a)e prejudiciais à vida aquática. Para aquários de água salgada ${ }^{4}$ é necessário que a filtragem seja por filtro do tipo Reversa Osmose (RO) (figura 5) para remoção de possíveis agentes de tratamento da água como cloro e outros sólidos dissolvidos prejudiciais à vida marinha como fosfato e outros(ARAÚJO; PÉREZ, 2005).

O controle da qualidade da água após a filtragem pode ser mensurado através da concentração do total de sólidos dissolvidos (TDS) com aparelho próprio para este fim (figura 6) e a água deve ser monitorada constantemente. A partir do momento que houver a saturação dos filtros, os valores do TDS começam a aumentar e os mesmos precisam ser trocados. Para aquários onde haja recife de corais recomenda-se uma água de até 5 ppm de TDS antes que haja a mistura do sal marinho. Recomenda-se que seja assinalado na tabela o tipo de filtro que foi trocado, o valor em ppm antes da troca, o valor de ppm depois da troca, com data e assinatura do responsável pela troca e supervisor (Apêndice 3).

\footnotetext{
${ }^{4}$ A água salgada artificial é feita a partir de água de RO e sal próprio para utilização em aquários de água salgada. O sal artificial para aquários de água salgada já vem com as concentrações corretas dos elementos necessários para a vida marinha.
} 
Figura 5 - Componentes de um sistema de Filtragem de Osmose Reversa da marca Express Water, com filtro de polipropileno (a), carvão ativado granular (b), carvão em bloco (c), membrana de RO (d) e carvão ativado granular (e).

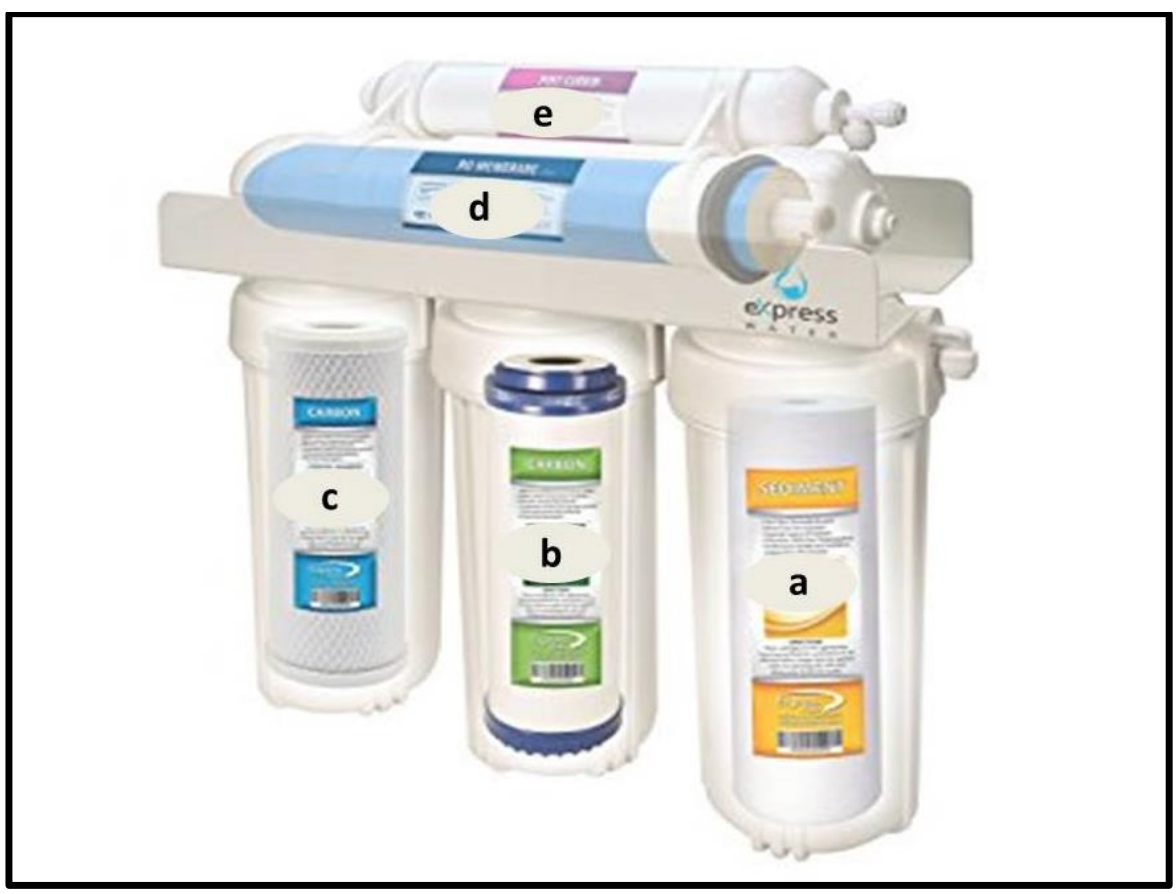

Fonte: Cardoso, 2016.

Figura 6 - Exemplo de equipamento para mensuração do total de sólidos dissolvidos (TDS) da marca HM Digital Water, com filtro de polipropileno(a), carvão ativado granular (b), carvão em bloco (c), membrana de RO (d) e carvão ativado granular (e).

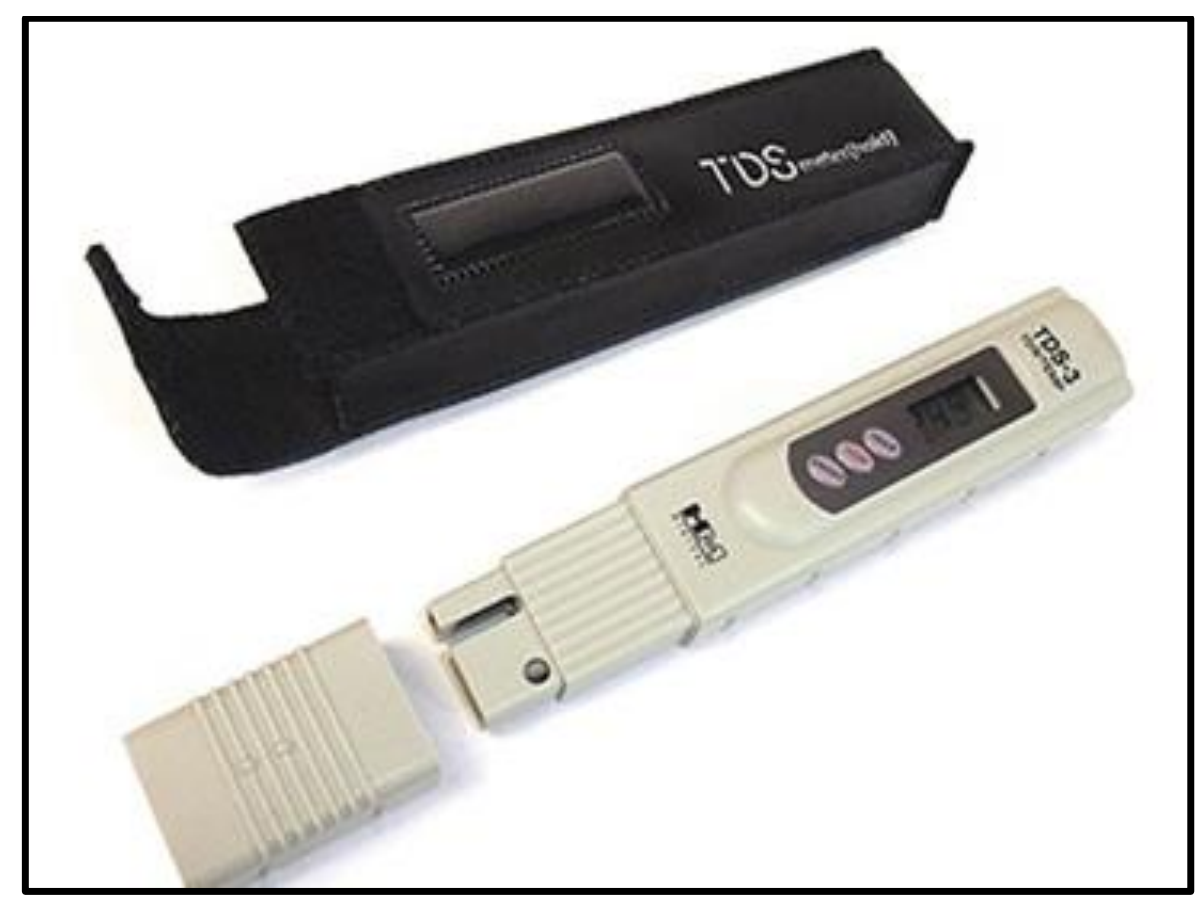

Fonte: Cardoso, 2016 
Após o tratamento da água que abastece os aquários, é necessário que haja também o tratamento da água de recirculação dos aquários com filtro de luz ultravioleta e/ou ozonização da água. Esse assunto será discutido no Capítulo 03, pois esse tipo de tratamento de água é para prevenção de doenças que possam vir com os peixes e será mais bem posicionada em tal capítulo.

\section{POP 2 Higienização das instalações, equipamentos e utensílios}

Métodos de higienização devem ser empregados como prática em programas de biosseguridade por estabelecimentos comerciais de aquicultura, de modo a excluir doenças específicas do sistema, bem como reduzir a incidência de outras. E para que os métodos de higienização cumpra com seus objetivos é necessário que orientações técnicas sejam seguidas para o correto cumprimento deste POP(OIE, 2012).

\section{Orientações técnicas sugeridas para o correto cumprimento do POP de Higienização das instalações, equipamentos e utensílios}

I) O estabelecimento deve manter suas instalações, equipamentos e utensílios devidamente identificados e em bom estado de conservação e funcionamento, de modo a assegurar limpeza e desinfecção.

II) O estabelecimento deve manter um responsável pela operação de higienização que seja comprovadamente capacitado.

III) A equipe de colaboradores deve estar bem capacitada em técnicas de limpeza e conhecer os riscos de contaminação e como evitá-los.

IV) O responsável pela higienização de banheiros e sanitários devem utilizar uniformes apropriados e diferentes daqueles utilizados pelos profissionais que trabalham na área de produção e manejo de animais.

V) Todos os produtos utilizados na limpeza e desinfecção devem ser aprovados pelo MAPA, preferencialmente indicados para uso em aquicultura, ter registro ativo, o que deve ser constantemente supervisionado pelo médico veterinário responsável técnico.

VI) Produtos químicos devem permanecer devidamente identificados e mantidos em local isolado da produção, sem nenhuma possibilidade de contato com os animais, de forma a não oferecer riscos de contaminação. A sua utilização deve respeitar as recomendações de uso do fabricante.

VII) Os estabelecimentos devem dispor de instruções de trabalho para todos os processos de higienização, descrevendo todos os tipos de superfícies a serem higienizadas, o método de higienização (etapas), a frequência, o responsável pela operação, os produtos químicos utilizados, o nome do produto comercial utilizado, a concentração e uso, além de informações como tempo de contato e outras que forem necessárias.

Antes da higienização é necessário remover o excesso de matéria orgânica que pode reduzir a eficácia da maioria dos desinfetantes. Os procedimentos de higienização devem incluir no mínimo quatro estágios (figura 7) e devem ser monitorados por colaborador capacitado(OIE, 2012). 
Figura 7: Etapas mínimas da higienização

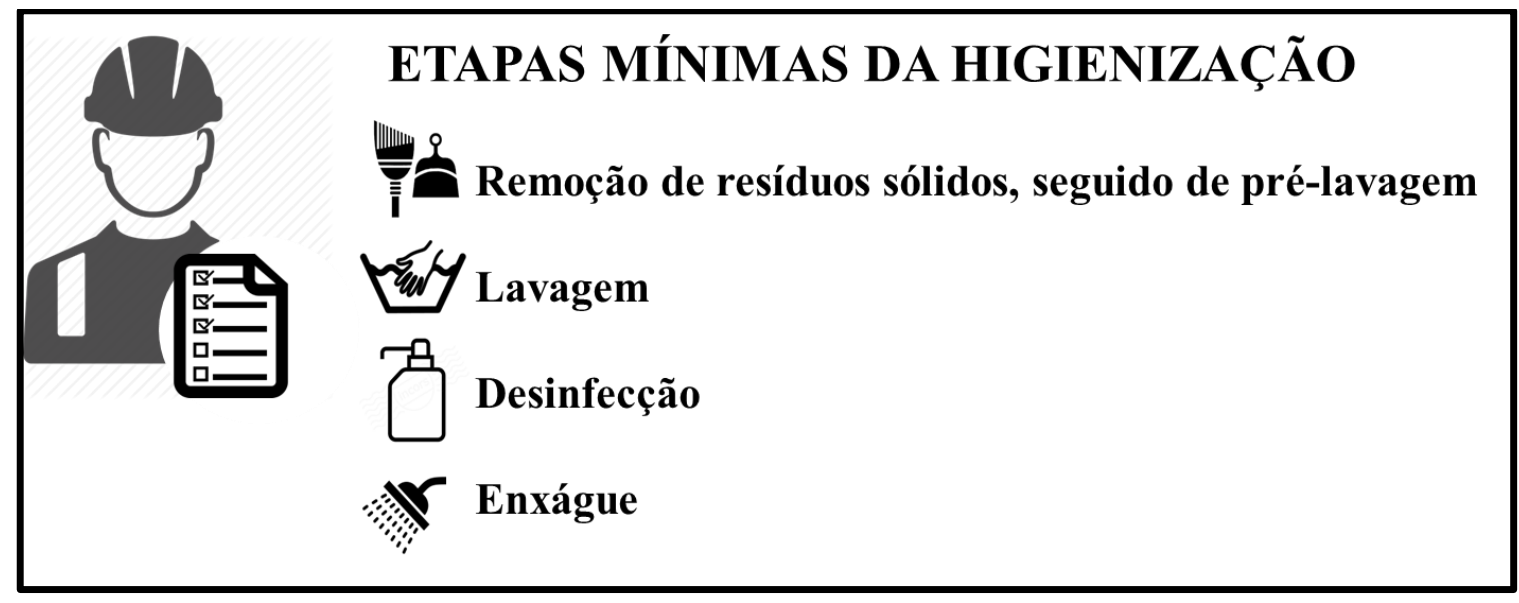

Fonte: Cardoso, 2016

- POP 3 Higiene e saúde dos colaboradores que lidam diretamente como os animais

Todos os colaboradores que trabalham em estabelecimentos destinados a comercialização de peixes ornamentais devem apresentar boas condições de saúde(BRASIL, 1978a), utilizar vestiário adequado à sua função (BRASIL, 1978b) (figura 8a), incluindo-se calçado fechado e a prova d'água, seguir hábitos higiênicos e apresentação e asseio pessoal.

$\mathrm{O}$ estabelecimento que não cumpre com o anteriormente mencionado (figura $8 \mathrm{~b}$ ), pode estar colocando seu negócio em risco em decorrência de problemas de natureza sanitária com relação aos animais e colaboradores humanos(BRASIL, 2005). São inúmeros agentes patogênicos e zoonóticos relatados em peixes ornamentais, sendo alguns deles de difícil tratamento, como exemplo o Mycobacterium marinum, causador de micobacteriose cutânea, frequentemente relatadas em países asiáticos, entre as chamadas doenças ocupacionais(AUBRY et al., 2002; PREARO et al., 2004; CHEUNG et al., 2012). 
Figura 8 - (a) Colaborador usando uniforme e EPI no manejo e peixes ornamentais; (b) colaborador sem uniforme e com vestimenta não conforme para o trabalho.

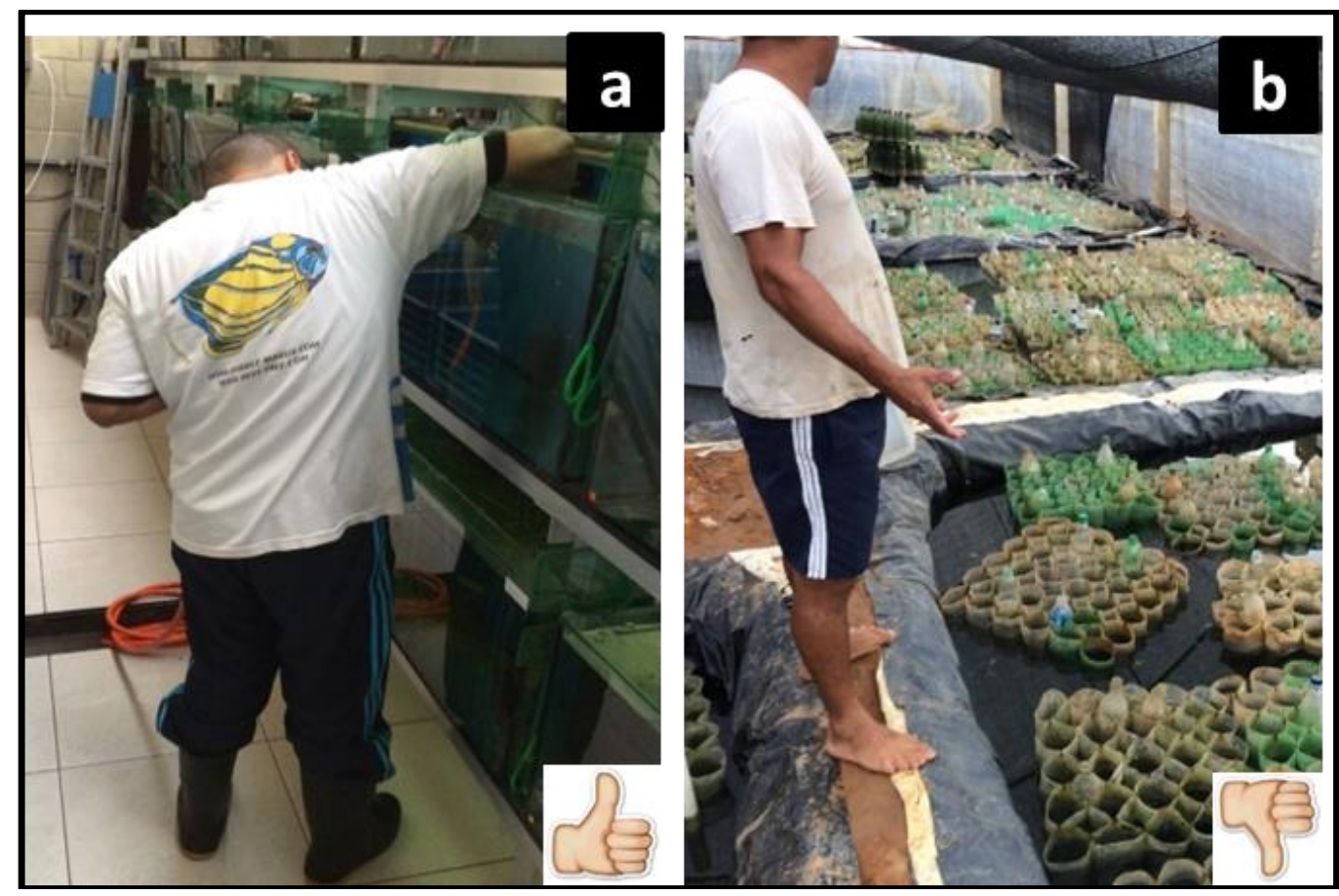

Fonte: Cardoso, 2016.

Além da capacitação inicial, quando da admissão do trabalhador, deverá receber periodicamente treinamentos para corrigir procedimentos, atualizá-los, alterá-los, sempre ajustando à melhor pratica em termos higiênicos e de manejo com os animais.

\section{Orientações técnicas sugeridas para o correto cumprimento do POP de Higiene e Saúde dos colaboradores}

I) Os colaboradores devem estar devidamente barbeados, com as unhas aparadas, limpas e sem esmalte, sem qualquer tipo de adornos como pulseiras, colares, anéis, fitas, relógio, piercing, brincos, cordões e similares.

II) Os uniformes devem ser de cor clara e devem estar sempre limpos e bem passados e não devem ser usados fora do ambiente de trabalho. Cores escuras devem ser evitadas pois pode esconder sujidades.

III) Sempre após a manipulação de aquários, animais e equipamentos devem lavar as mãos com sabão bactericida e secar as mãos com papel toalha.

IV) Os colaboradores que estiverem na área interna da empresa, não devem cuspir, fumar, mascar chicletes ou consumir alimentos, sentar no chão, usar cremes, perfumes ou loções.

V) Todos os que manipulam aquários devem usar botas como EPI e luvas e máscaras quando for manipular produtos químicos e peixes doentes ou mortos.

VI) É necessário que todos os ambientes como copa, banheiros, área de produção, manipulação tenham sabonete bactericida e papel toalha para secar as mãos.

VII) Os colaboradores deverão ser submetidos a exame médico anualmente, comprovando que não sofrem de doenças que os incompatibilizem com os trabalhos.

VIII) Sempre que ficar comprovada a existência de dermatoses, doenças infectocontagiosas ou repugnantes, os colaboradores deverão ser imediatamente afastados do trabalho. 


\section{- POP 4 Manejo de resíduos}

Todo o material não útil na produção é considerado resíduo, vulgarmente lixo. O lixo sólido deve ser acondicionado em recipientes próprios, providos de tampa, ser de material impermeável, de fácil limpeza e revestido com saco plástico resistente de cor preta (figura 9a) para lixo inorgânico e saco plástico branco leitoso para lixo orgânico (animais e carcaças de animais mortos) com símbolo de resíduo infectante (BRASIL, 2004) (figura 9b).

Figura 9: (a) Armazenamento de lixo inorgânico em saco plástico preto; (b) Armazenamento de lixo orgânico em saco plástico branco leitoso.

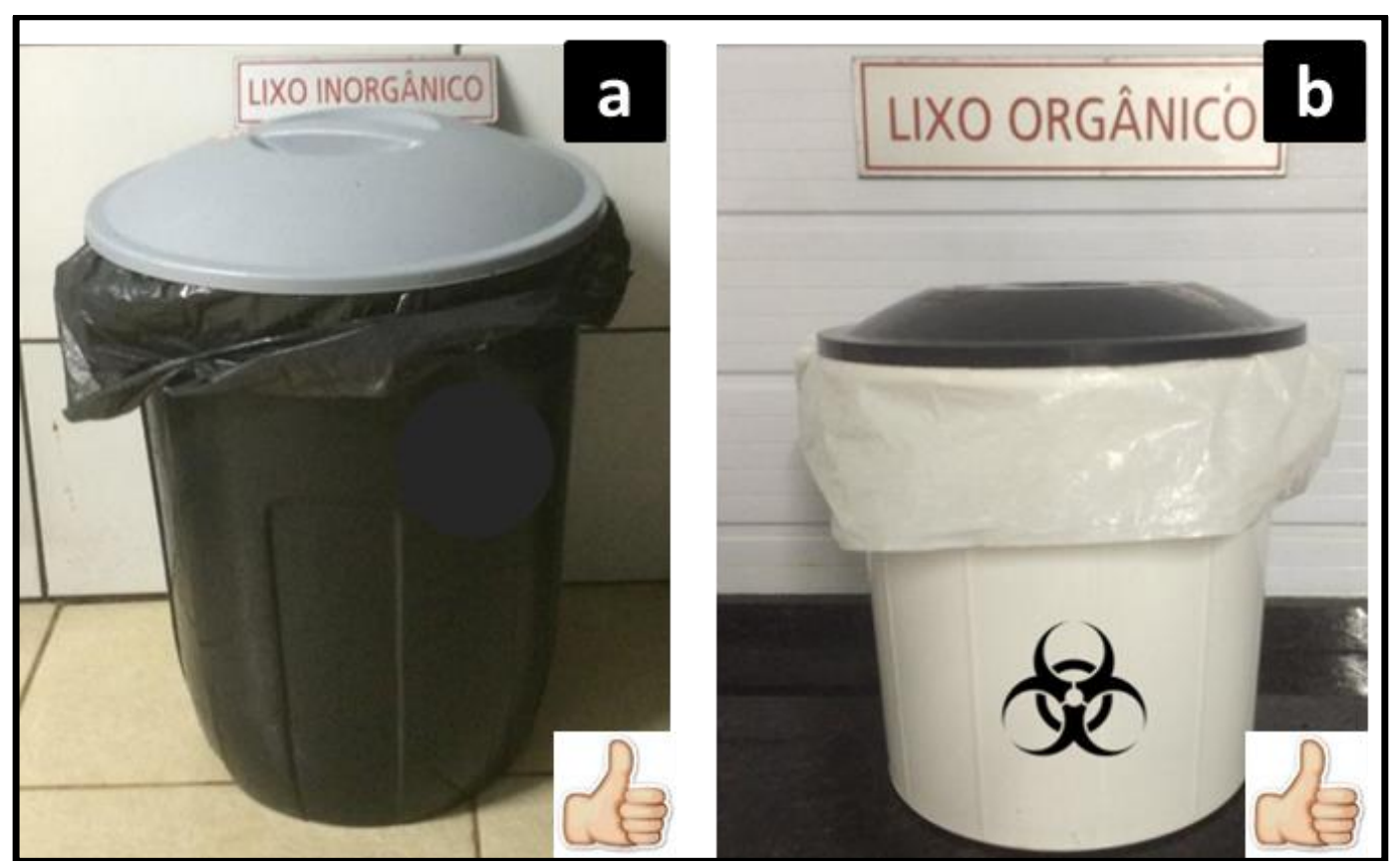

Fonte: Cardoso 2016

O lixo deve ser armazenado em recipiente fechado, isolado das áreas de produção até ser recolhido pela empresa responsável pela coleta. O local deve ser lavável e protegido, provido de ponto de água e devidamente identificado.

O recolhimento para o destino final deve ser realizado em veículos fechados e em horários que não comprometam o fluxo de produção do estabelecimento. $\mathrm{O}$ material orgânico (que inclui peixes mortos) deve ser incinerado ou coletado por empresa terceirizada que realiza tal procedimento(BRASIL, 2008a).

Os recipientes devem ser devidamente higienizados ao final do expediente com desinfetantes devidamente registrados no MAPA preferencialmente apropriados para o uso em estabelecimentos de aquicultura(BRASIL, 2015a). Atualmente a Cloramina-T, desinfetante recomendado pela OIE é um dos mais utilizados na aquicultura mundial (ALTINOK, 2004; 
GAIKOWSKI et al., 2004)(SMAIL et al., 2004) e já possui registro no MAPA para comercialização no Brasil.

A água na qual os peixes ornamentais são transportados ou alojados apresentam uma alta prevalência de microrganismos, entre eles agentes patogênicos, principalmente de etiologia bacteriana. Diversos trabalhos científicos comprovam a presença de agentes bacterianos altamente resistentes capazes de colocar a saúde humana e dos animais em risco caso mantenham contato com hospedeiros susceptíveis (TRUST; BARTLETT, 1974; TRUST; WHITBY, 1976; LEHANE; RAWLIN, 2000; VERNER-JEFFREYS et al., 2009; WEIR et al., 2012; ROSE et al., 2013; GAUTHIER, 2015).

As águas residuais advindas do transporte de peixes ornamentais e de trocas no momento da manutenção dos aquários devem ser tratadas em local apropriado antes de serem descartadas na rede coletora. Os tratamentos podem ser feitos utilizando cloração, luz ultravioleta (figura10), ozonização ou outro desinfetante devidamente regulamentado para uso em aquicultura (BRASIL, 2015a).

Figura 10: Exemplo esquemático de luz ultravioleta utilizada para tratamento de água em aquarismo. A água entra contaminada (a) e sai tratada (b).

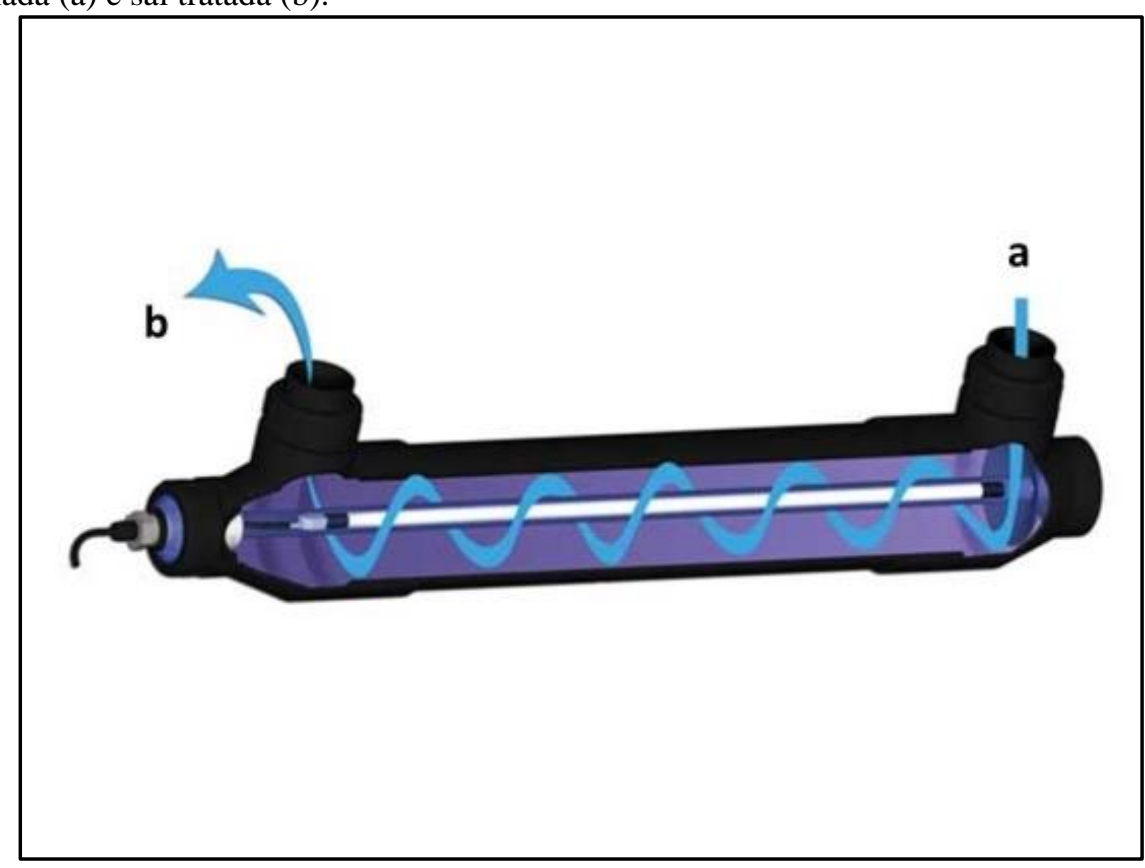

Fonte: Cardoso, 2016

É importante salientar que a velocidade necessária para inativar patógenos é bastante variável. Geralmente as doses de irradiação ultravioleta para inativar bactérias são inferiores àquelas utilizadas em sistemas de irradiação utilizadas para inativar agentes virais e parasitários. Outro fator importante é que a água que passa pela luz ultravioleta deve estar límpida, caso 
contrário a esterilização da água fica comprometida (OATA, 2006; KENT et al., 2009a; OIE, 2012).

É fundamental que a eficácia do sistema escolhido e implementado seja verificada através de análises microbiológicas da água antes e depois do tratamento. Recomenda-se avaliar as concentrações de microrganismos aeróbios mesófilos, bolores e leveduras e agentes de interesse específico.

\section{- POP 5 Manutenção preventiva e calibração de equipamentos}

A manutenção preventiva é um procedimento que deve ser efetuado com a intenção de reduzir a probabilidade de falhas nos equipamentos utilizados no estabelecimento. É uma intervenção que deve ser prevista, preparada e programada antes da data provável do aparecimento de uma falha(BERTINI; MENDES., 2011). Compreendem inspeções sistemáticas, ajustes, trocas, conservação e eliminação de defeitos, visando a evitar falhas.

O período de revisão é baseado em recomendações do fabricante, frequência de uso do equipamento e histórico da frequência de problemas já ocorridos. Enquadram-se nessa categoria as revisões sistemáticas do equipamento, as lubrificações periódicas, os planos de inspeção de equipamentos e os planos de calibração e de aferição de instrumentos. Alguns equipamentos como peagâmetros podem se descalibrar facilmente em decorrência da alta frequência de utilização, principalmente em água com diferentes valores de $\mathrm{pH}$. Sendo assim, equipamentos desse tipo devem ser armazenados conforme indicado pelo fabricante e calibrados frequentemente (figura 11). 
Figura 11 - Exemplo de Kit de pH da marca HM Digital®, com solução de calibração de pH (a), aparelho peagâmetro (b) e solução para estoque do eletrodo.

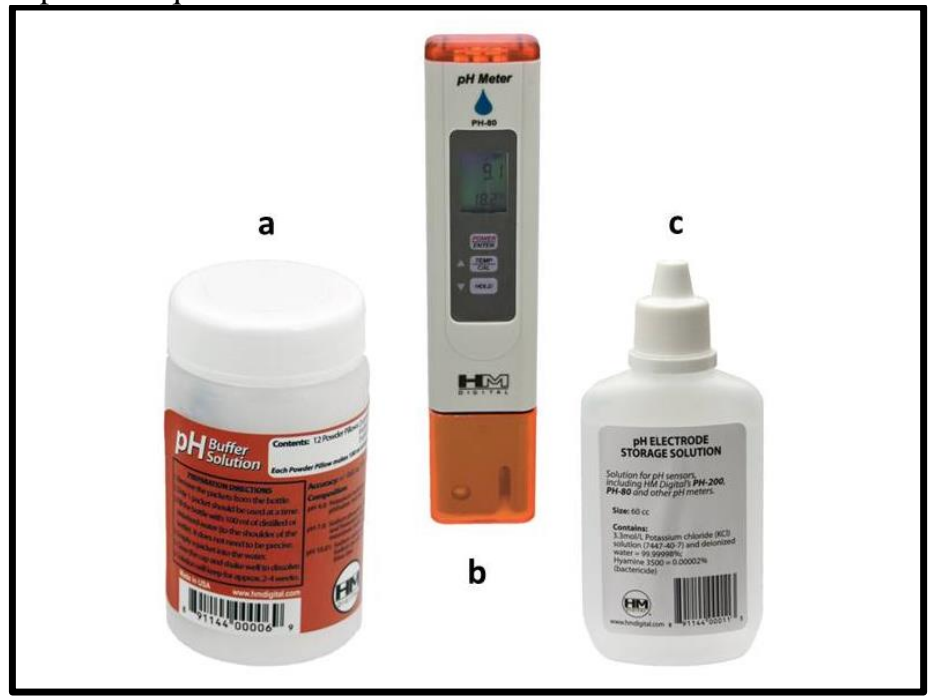

Fonte: Cardoso, 2016

\section{- POP 6 Controle integrado de vetores e pragas}

Tratando-se de controle de vetores e pragas, devem ser respeitadas todas as condições, sejam elas estruturais ou de manejo, que evitem os chamados '4As', isto é, evitar situações favoráveis de Atração, Abrigo, Alimento e Água. O estabelecimento deve adotar medidas que dificultem ao máximo o acesso de vetores e animais sinantrópicos (BRASIL, 2015a).

\section{Orientações gerais para o controle de vetores e pragas}

As instalações não devem ter:

- Possíveis pontos de entrada de insetos no ambiente, como falhas de vedação em tubulações, ralos sem proteção, portas e janelas mal vedadas, etc.

- Acúmulo de água em drenos, ralos ou caixas de inspeção;

- Falhas na manipulação e guarda de lixo;

- Presença de entulho, materiais fora de uso, caixas e embalagens mal armazenadas;

Quaisquer sinais de roeduras, fezes, trilhas, pegadas e ninhos de roedores devem ser notificados, bem como carcaças de insetos, penas, ovos, odores de pragas, etc.;

Não devem existir resíduos que sirvam de alimento a aves, roedores e insetos;

Devem ser desenvolvidos programas de limpeza e higiene junto aos funcionários;

O lixo deve ser devidamente acondicionado e retirado com frequência;

São proibidos gatos, cães, ou qualquer outro animal doméstico;

Quaisquer indícios de casulos e teias, larvas, fungos ou traças, trilhas e grãos atacados devem ser notificados;

Linhas de esgoto e efluentes devem ser totalmente isoladas;

Paredes e superfícies devem ser lisas com juntas de dilatação;

Roedores mortos devem ser incinerados ou enterrados;

As medidas corretivas, por sua vez, compreendem à instalação de barreiras físicas que impeçam o acesso das pragas e à colocação de armadilhas para captura e identificação das espécies infestantes.

O controle químico, apesar da ênfase maior em ações preventivas, também está presente, mas com um papel coadjuvante de complementar as orientações de limpeza e higiene. 
Quando da necessidade de utilização de substancias químicas é obrigatório contratar os serviços de empresa especializada em desinssetização e desratização. Os certificados de execução deverão ser mantidos atualizados e de fácil acesso, em caso de serem exigidos pela fiscalização (BRASIL, 2008c).

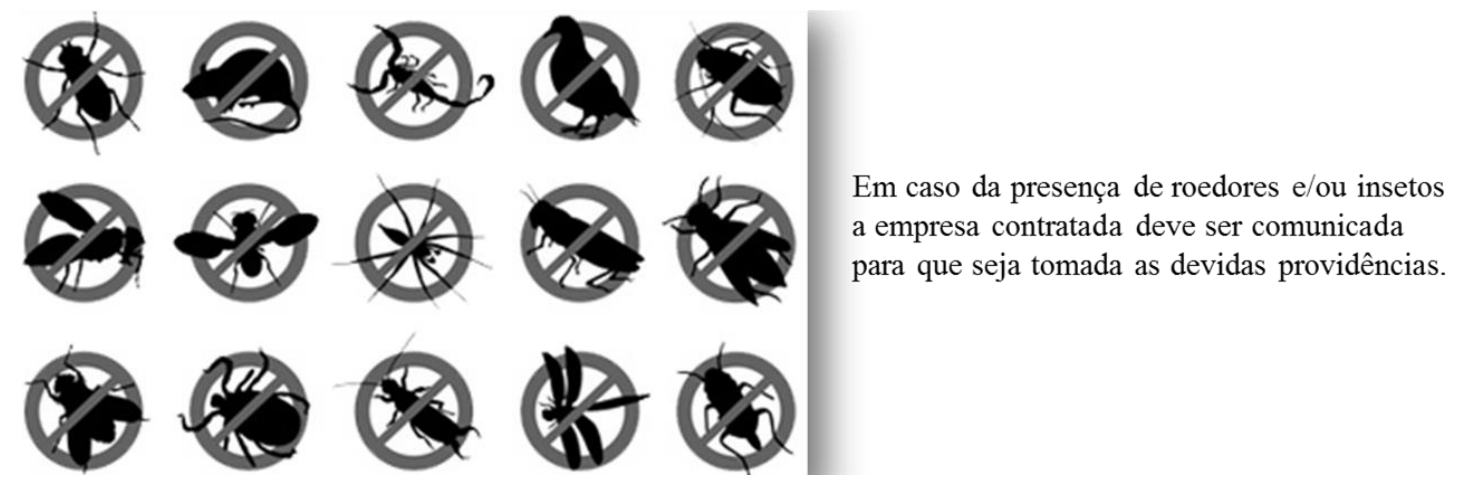

\section{- POP 7 Seleção de fornecedores dos animais a serem comercializados}

Os estabelecimentos comerciais de peixes ornamentais devem exigir que seus fornecedores também adotem boas práticas de manejo e higiene e estruturem seus próprios programas de autocontrole higiênico sanitário de processos(OATA, 2006). Somente assim é possível reduzir a níveis aceitáveis problemas sanitários; situação bastante favorável a todos os atores dessa cadeia produtiva.

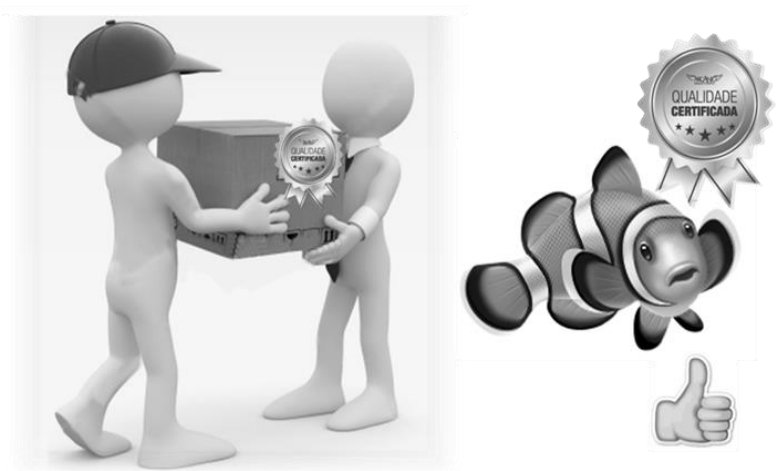

Os animais a serem comercializados pelo estabelecimento, devem ser adquiridos de fornecedores que adotem medidas relacionadas às boas práticas de manejo e higiene na aquicultura.

Para maior segurança, o estabelecimento deve adotar protocolos de verificação e controle no recebimento dos animais (Apêndice 4), o que obriga o fornecedor a entregar animais em estado sanitário satisfatório (FOSSA et al., 2009), caso contrário os animais poderão ser recusados e o fornecedor advertido. Sugere-se que sejam construídos históricos dos fornecedores, registrando-se todas as ocorrências de inconformidades nos seus produtos. A partir daí pode-se determinar limites de inadequações inaceitáveis que resultem em bloqueio de compras de um determinado fornecedor até que ele comprove a correção de tais falhas. 
Animais doentes, prostrados ou que apresentam-se muito estressados devem ser recusados e o responsável pela entrega notificado. Havendo a repetição do mesmo erro por mais de três vezes, recomenda-se que o estabelecimento bloqueie o fornecedor.

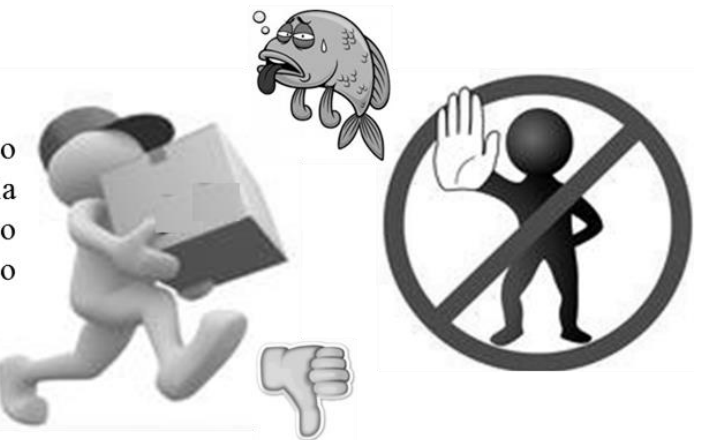

$\mathrm{Na}$ expedição deve-se reavaliar as condições gerais dos animais que serão distribuídos aos clientes. É fundamental estabelecer um check list de expedição, obedecendo a rigorosos critérios de qualidade (Apêndice 5). Em hipótese alguma devem ser enviados animais debilitados ou com suspeita de alguma doença.

\section{- POP 8 Programa de ação para animais doentes e recolhimento de animais mortos}

Animais que apresentarem sinais de prostração ou sinais clínicos que condizem com doença deverão ser tratados ou sacrificados, de acordo com as orientações recomendadas pelo Médico Veterinário Responsável Técnico, a partir do diagnóstico por ele estabelecido (figura 12).

Figura 12 - Exemplo de estado sanitário de peixes no recebimento e ação executada pelo médico veterinário responsável técnico do estabelecimento receptor.

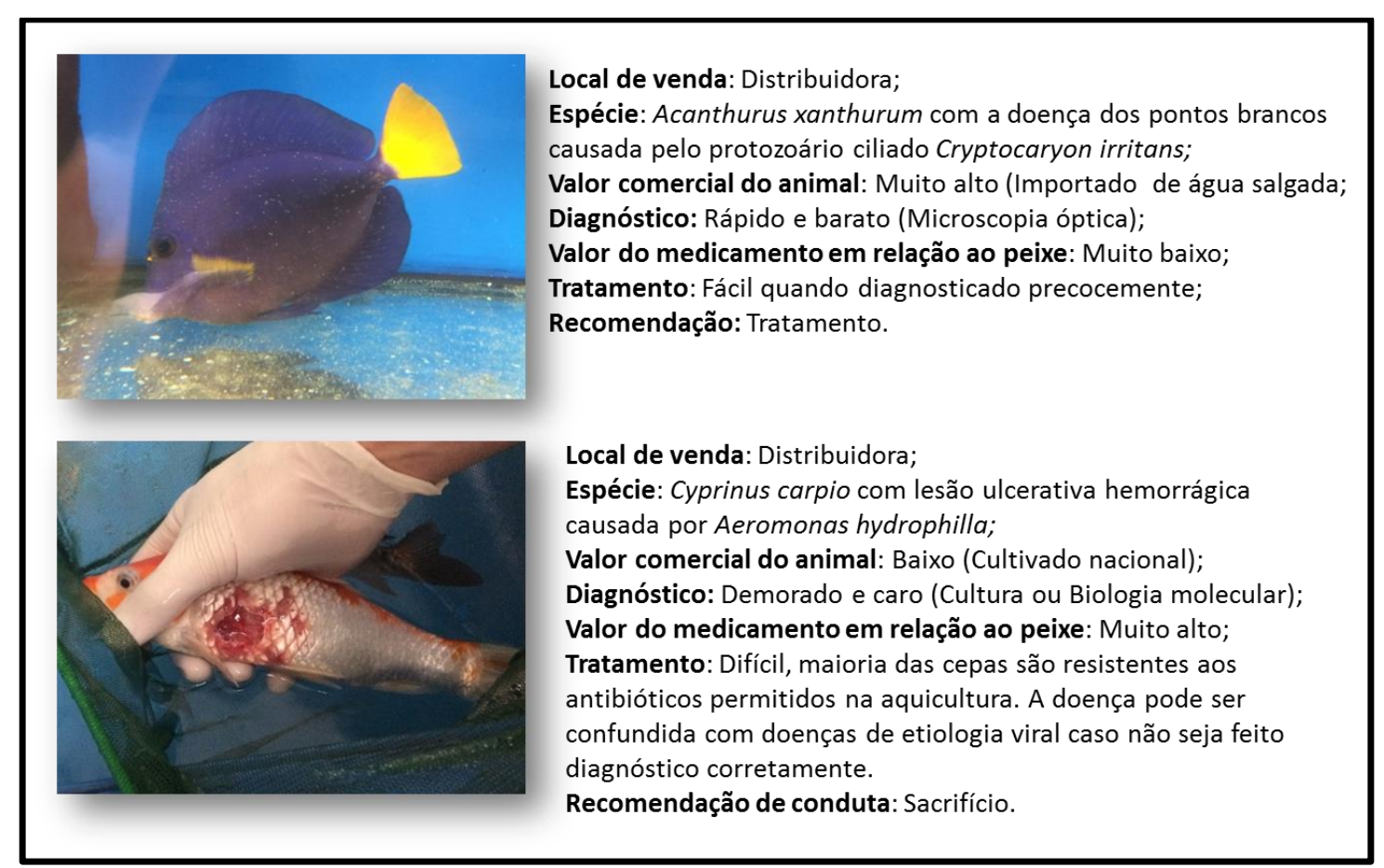

Fonte: Cardoso, 2016 
Em estabelecimento atacadista de peixes ornamentais recomenda-se que animais mortos sejam recolhidos, no mínimo, duas vezes ao dia, no início e imediatamente antes do final do expediente. Essa prática é necessária, pois peixes mortos ou doentes em aquários causam impressões negativas aos clientes, além de que, o monitoramento da mortalidade pode ser um indicativo de problema que está acontecendo com determinada espécie ou até mesmo no estabelecimento como um todo. Recomenda-se que todos os animais mortos sejam acondicionados em Formol a 10\% antes de serem descartados como resíduo orgânico em envoltório próprio. Acondicionar em formol a $10 \%$ garante que haja interrupção da deterioração da carcaça e consequentemente a produção de odores desagradáveis.

Aqueles aquários que tiverem uma alta taxa de mortalidade deverão ser avaliados com mais precisão com o intuito de diagnosticar o problema, e se necessário, coleta de amostras para análise de acordo com a indicação do Médico Veterinário Responsável Técnico.

O estabelecimento deve manter o registro de todas as doenças diagnosticadas e identificadas. Em caso de suspeita de doenças de notificação obrigatória, os órgãos executores de sanidade animal deverão ser comunicados(BRASIL, 2003).

\subsubsection{Descrição do produto}

Os peixes ornamentais comercializados no estabelecimento devem ser regulamentados segundo legislação do IBAMA e MAPA (BRASIL, 2006, 2014a) e devem ser divididos em grupos ou subgrupos. É importante que haja descrição detalhada sobre cada um dos grupos ou subgrupos de animais (figura 13). 
Figura 13: Representação gera dos grupos de animais comercializados na empresa utilizada como cenário, localizada na grande São Paulo.

\begin{tabular}{|c|c|}
\hline Grupo de produtos 1 (Áqua doce) & Grupo de produtos 2 (Áqua salgada) \\
\hline $\begin{array}{l}\text { PROCEDÊNCIA: nacional de pesca extrativa, nacional de } \\
\text { cultivo e importado de cultivo. }\end{array}$ & $\begin{array}{l}\text { PROCEDÊNCIA: nacional de pesca extrativa, nacional de cultivo, } \\
\text { importado de pesca extrativa e Importado de cultivo. }\end{array}$ \\
\hline $\begin{array}{l}\text { Forma de recebimento: embalagens de polietileno (sacos } \\
\text { plásticos) e caixas de poliestileno (isopor). }\end{array}$ & $\begin{array}{l}\text { Forma de recebimento: embalagens de polietileno (sacos } \\
\text { plásticos) e caixas de poliestileno (isopor). }\end{array}$ \\
\hline Forma de aclimatação: Ajuste de $\mathrm{pH}$ e temperatura & Forma de aclimatação: Ajuste de $\mathrm{pH}$ e temperatura. \\
\hline Faixa de temperatura para armazenamento: +26 até $+30^{\circ} \mathrm{C}$. & Faixa de temperatura para armazenamento: $+26^{\circ} \mathrm{C}$. \\
\hline $\begin{array}{l}\text { Faixa de pH para armazenamento: levemente ácido, neutro } \\
\text { e alcalino. }\end{array}$ & $\begin{array}{l}\text { Faixa de pH para armazenamento: Alcalino ( } 8.0 \text { a } 8.4) \text {. } \\
\text { Faixa de salinidade: } 1,020 \text { a } 1,023 \text {. }\end{array}$ \\
\hline $\begin{array}{l}\text { Método de embalagem: sacos de polietileno (sacos } \\
\text { plásticos), água limpa, condicionador de água e oxigênio. } \\
\text { Forma de transporte: caixas de Poliestileno (isopor) em } \\
\text { carro fechado e aclimatizado. }\end{array}$ & $\begin{array}{l}\text { Método de embalagem: sacos de polietileno (sacos plásticos), } \\
\text { água limpa, condicionador de água e oxigênio. } \\
\text { Forma de transporte: caixas de poliestileno (isopor) em carro } \\
\text { fechado e aclimatizados. }\end{array}$ \\
\hline
\end{tabular}

Fonte: Cardoso, 2016

\subsubsection{Identificação do uso pretendido do produto}

Os peixes ornamentais comercializados no empreendimento devem ser identificados quanto ao uso pretendido por seus consumidores.

No empreendimento utilizado como cenário os animais são comercializados para empreendimentos varejistas (figura 14) que devem receber animais saudáveis e em bom estado nutricional. Os animais com as características citadas anteriormente dificilmente causarão prejuízos ao varejista e ao consumidor, desde que, este último ofereça as condições necessárias para a sobrevivência e bem estar dos animais. 
Figura 14 -Representação de loja de varejo do setor de aquarismo do grupo Petz® em São Paulo

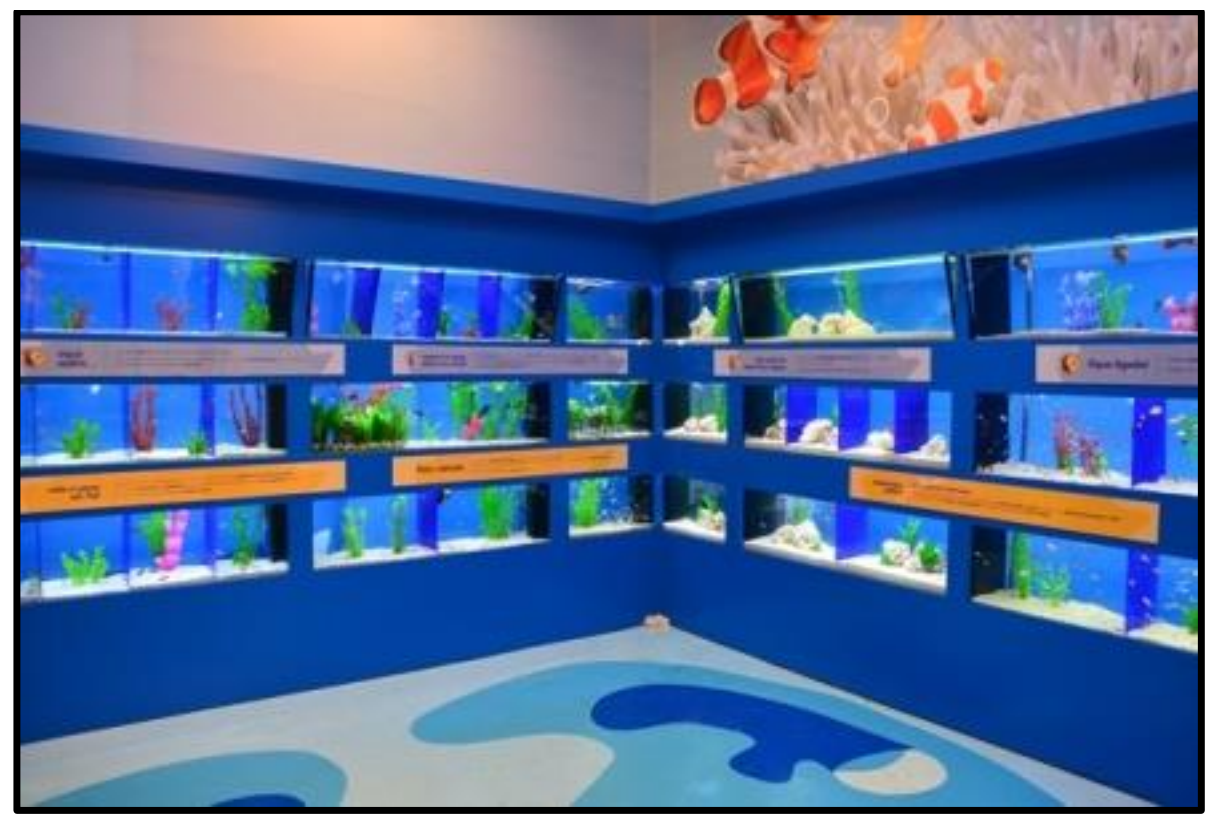

Cardoso, 2016

\subsubsection{Diagrama de fluxo (figura 15).}

Figura 15 - Diagrama de fluxo da área de processamento do produto da entrada até a expedição e recomendações para cada etapa do processo

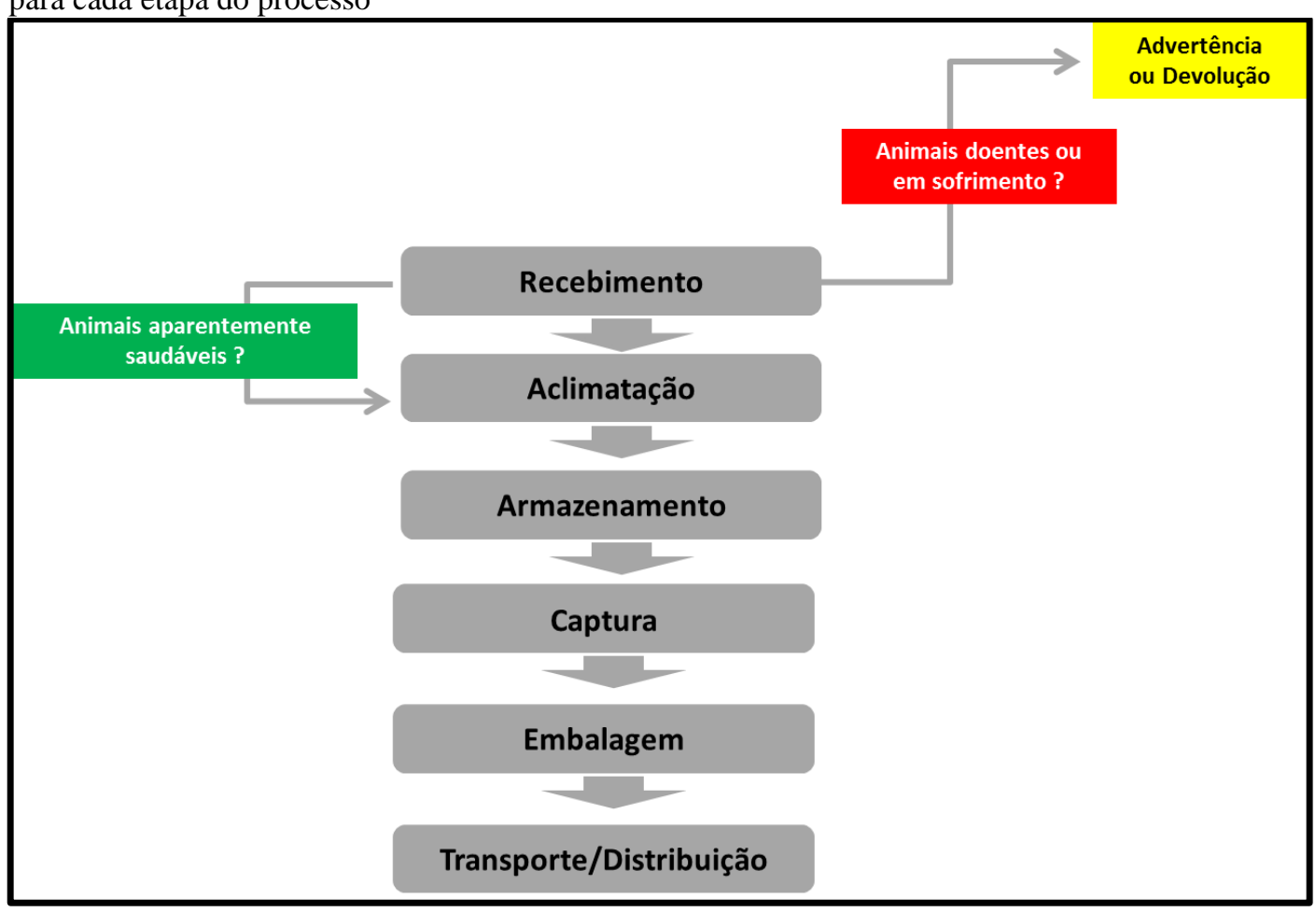

Fonte: Cardoso, 2016 


\subsubsection{Recebimento}

O recebimento dos animais deve ser programado, expondo o menor tempo possível os animais às condições ambientais de excesso de calor, frio, irradiação solar. Deve ser realizado por um único responsável.

A área de recebimento deve possuir estrados impermeáveis (figura 16a) de fácil higienização. Cada uma das embalagens (sacos de polietileno) deve ser manuseada e transportada cuidadosamente, evitando movimentos bruscos e excessos de ruídos, reduzindo ao máximo a geração de estímulos geradores de estresse aos animais(CROSBY et al., 2014) e consequentemente a ocorrência de doenças e mortes. Jamais dispor as embalagens diretamente no chão (figura 16b), pois esta prática gera alteração de temperatura, intenso estresse aos animais, riscos de rompimento dos sacos plásticos e contaminação por diversos agentes patógenos, além de contaminar, posteriormente os aquários quando da transposição dos animais (PLOEG; BASSLEER; HENSEN, 2009).

Figura 16: (a) Peixes ornamentais na área de recebimento acondicionados em estrados impermeáveis e higienizados previamente ao recebimento; (b) Peixes ornamentais erroneamente em contato direto com o chão em área não exclusiva para o recebimento

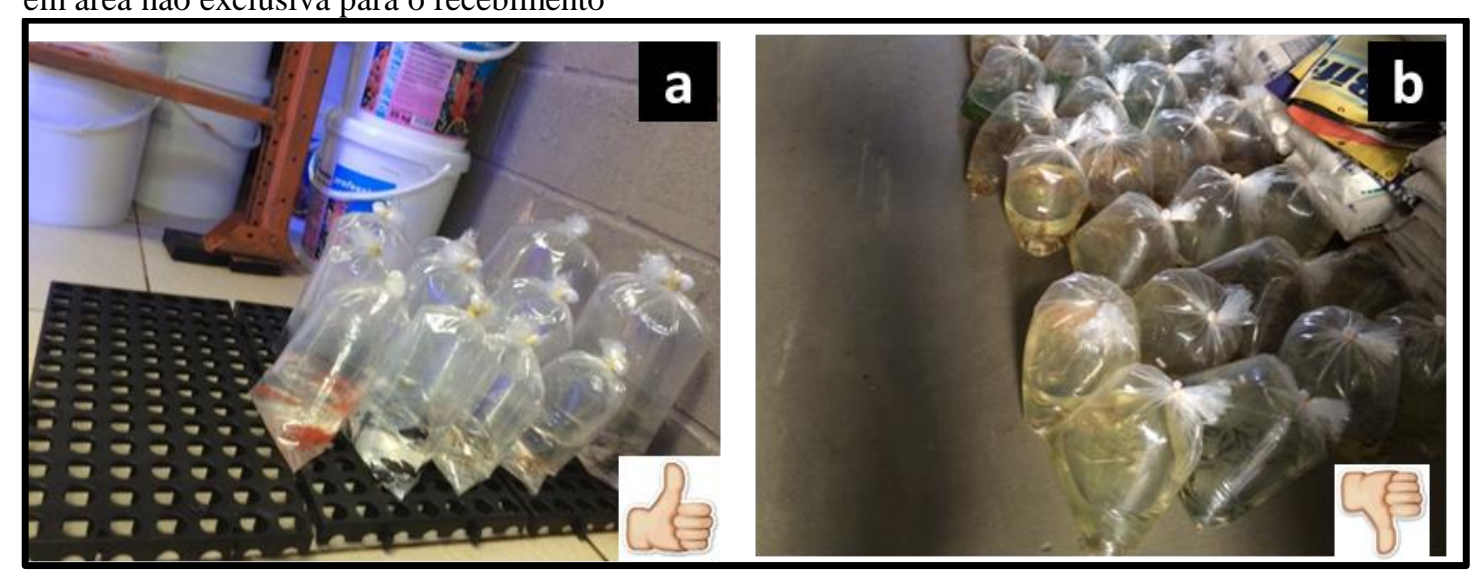

Fonte: Cardoso, 2016

\subsection{Inspeção visual}

Após o recebimento, já sob os estrados, as embalagens, a água e os peixes devem ser cuidadosamente inspecionados visualmente (figura 17a), avaliando as condições de saúde, de comportamento, refletindo o grau de bem estar, coloração da água, turgidez da embalagem.

Animais doentes, moribundos e em estado de sofrimento ou com lesões sugestivas de infecção e/ou infestação por patógenos devem ser rejeitados e o fornecedor deve ser advertido. Os animais saudáveis devem ser imediatamente separados em carrinho de aço inoxidável ou caixas de plástico (figura 17b), preenchido o relatório de recebimento, 
descrevendo as condições dos animais e então serem encaminhados para os aquários de destino (Armazenamento), dando início ao processo de aclimatação e posterior soltura.

Figura 17 - (a) Inspeção visual inicial ainda no recebimento para avaliação das condições de saúde e bem estar dos peixes ornamentais; (b) Acondicionamento das embalagens com peixes aprovados na inspeção visual, sendo levados para área de armazenamento/estocagem

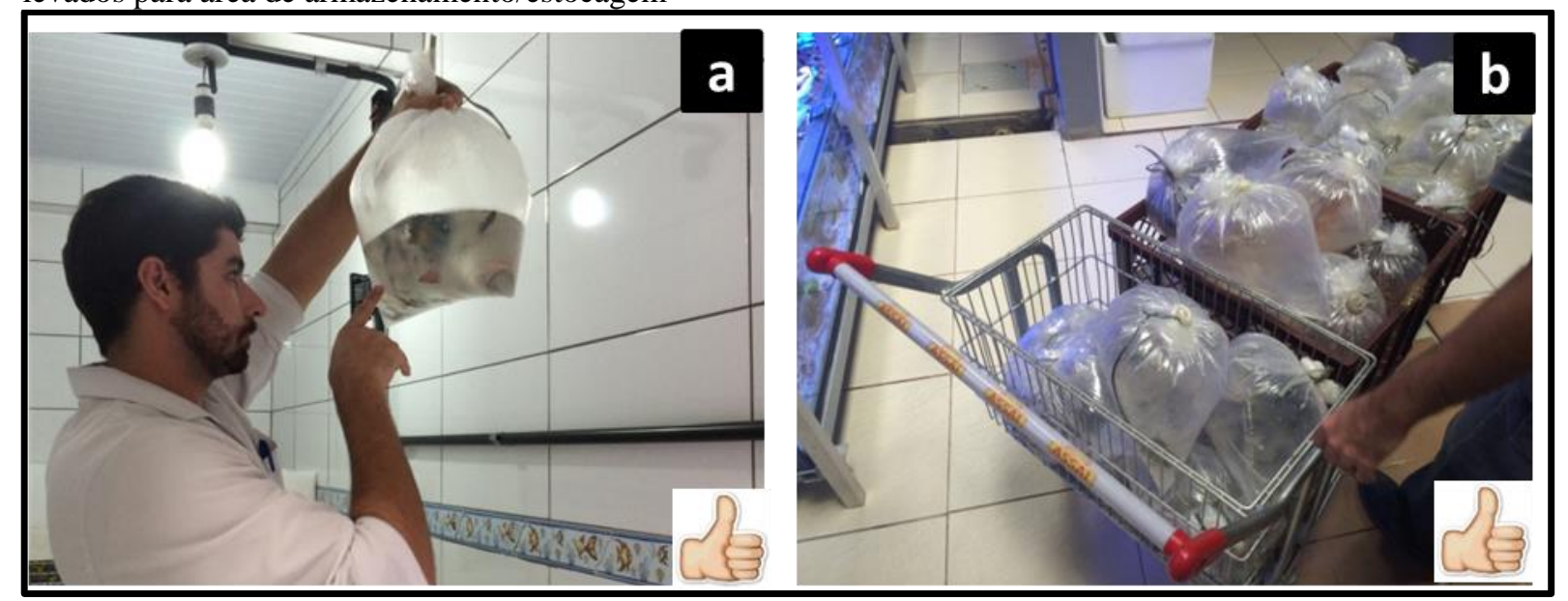

Fonte: Cardoso, 2016

Após o término do procedimento de recebimento os estrados impermeáveis devem ser limpos e desinfetados (higienização) com solução desinfetante em concentração e tempo suficiente par inativar qualquer agente patogênico que pode vir a ganhar os sistemas de água dos aquários.

Os procedimentos de higienização devem incluir no mínimo os estágios de remoção dos resíduos sólidos seguido de pré-lavagem, lavagem, desinfecção e enxágue. Tais procedimentos devem ser monitorados por profissional tecnicamente capacitado, registrandose todos os procedimentos realizados(OIE, 2012). Somente após essa prática, o novo lote poderá ser recebido. A adoção rotineira desta conduta tem por finalidade reduzir possibilidades de contaminações e prejuízos de natureza sanitária em todo o sistema e deve ser controlada diariamente (Apêndice 6).

\subsubsection{Aclimatação}

Aclimatação significa criar uma situação de transição entre as condições nas quais os peixes chegaram (embalagens plásticas) e os aquários nos quais serão mantidos até a expedição. Esse processo deve acontecer entre 15 e 60 minutos, não ultrapassando tais limites, inferior e superior (FOSSA et al., 2007).

É válido relembrar que a água na qual os animais são transportados possui valores de temperatura, $\mathrm{pH}$, salinidade, dureza, entre outros parâmetros bastante diferentes daqueles dos 
aquários de manutenção onde serão alocados. Peixes e especialmente invertebrados (incluindo corais) são extremamente sensíveis a pequenas mudanças nos parâmetros de água. Logo, uma aclimatação apropriada deve ser empregada com intuito de permitir que haja o menor grau de estresse possível e máximo bem estar e saúde para os animais.

Caso haja diferença de mais de $1,5^{\circ} \mathrm{C}$ entre a embalagem de origem e o aquário de destino, deve-se mergulhar os sacos plásticos nos aquários de destino para que haja equilíbrio de temperatura. Esse procedimento deve durar no mínimo 15 minutos (tempo necessário para igualar a temperatura da embalagem e do aquário destino).

É comum durante a viagem, o pH da água de transporte diminuir em consequência do metabolismo do peixe(CROSBY et al., 2014), por esse motivo, após a padronização da temperatura deve ser feito a ajuste no $\mathrm{pH}$ da água do aquário de destino de acordo com o $\mathrm{pH}$ da água de origem, diminuindo assim os riscos de estresse fisiológico nos peixes.

Outro parâmetro importante que deve ser monitorado é a dureza da água de origem ou procedência dos peixes e aquela na qual serão transferidos (de destino). Após a aclimatação os peixes devem ser isolados em aquários previamente identificados para que haja recuperação do estresse sofrido durante a viagem; antes que sejam liberados para venda.

A empresa deve conhecer o melhor método de aclimatação para cada uma das espécies comercializadas para que haja o mínimo de perda possível na aclimatação. Nessa etapa pode ser empregado o tratamento preventivo contra determinados ectoparasitas que será discutido posteriormente no Capítulo 3 da presente tese. Após a aclimatação, os animais devem ser cuidadosamente soltos nos aquários destinos de acordo o tipo de água da espécie. É recomendável que sejam elaborados POPs para a aclimatação dos diferentes tipos de peixes, de modo que o colaborador proceda sempre de forma correta.

\subsubsection{Armazenamento/Estocagem}

Os aquários destinados à manutenção dos peixes devem ser previamente escolhidos e possuir os parâmetros ideais para cada espécie (figura 18a). Cada aquário ou bateria de aquáriosdestino devem ter uma tabela fixada, de uma maneira que não molhe (figura 18b) para o monitoramento dos parâmetros indicadores da qualidade da água. A tabela deve conter os valores dos principais parâmetros para as espécies em questão e os mesmos devem ser monitorados diariamente (Apêndice 7) ou a critério do Responsável Técnico (com testes químicos disponíveis no mercado dedicados ao aquarismo ou aparelhos eletrônicos devidamente calibrados). 
Figura 18 - (a)Aquário com uma única espécie (variedade) de peixe ornamental, devidamente identificado; (b) Exemplo de tabela em bateria de aquários com valores dos parâmetros de qualidade de água e registro das ações empregadas no monitoramento dos aquários

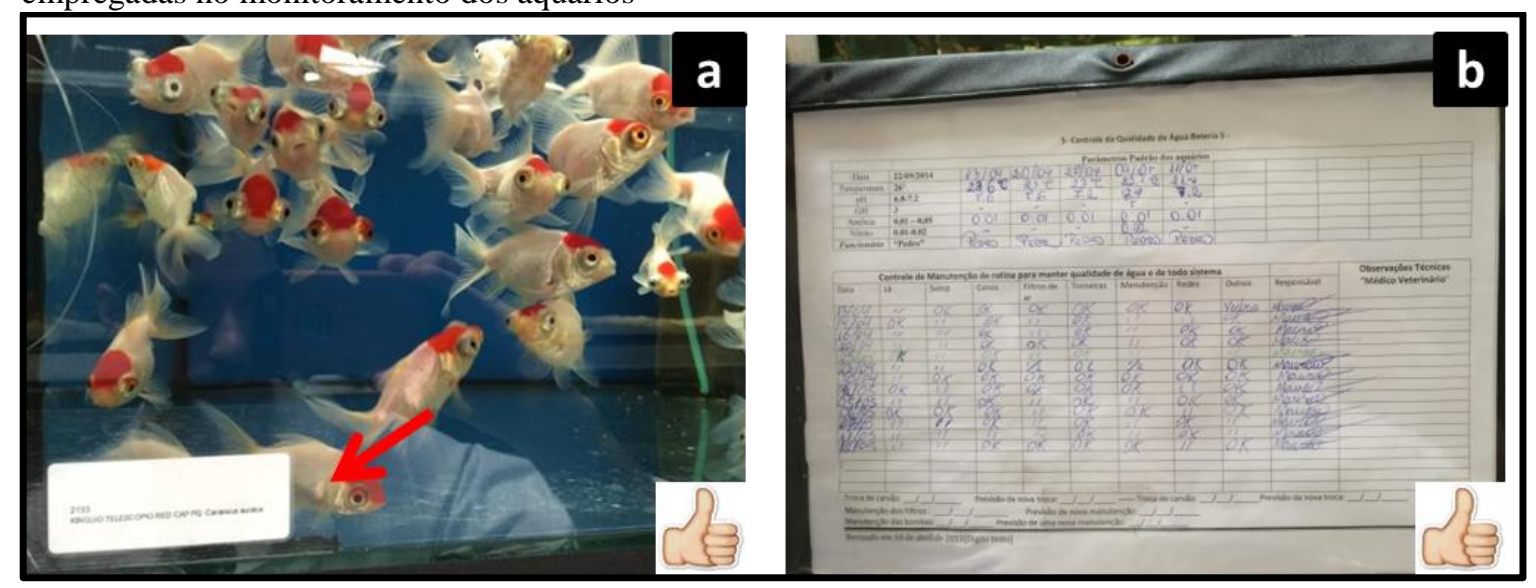

Fonte: Cardoso, 2016

Nessa etapa os peixes devem ser alimentados no mínimo duas vezes ao dia com ração balanceada e registrada no MAPA. Alimentos vivos devem ter uso restrito, e recomenda-se o uso somente em casos extremos em que o animal não esteja comendo em hipótese alguma o alimento processado. Cuidado muito especial deve ser mantido aos alimentos vivos, valendo todos os cuidados descritos neste guia também para a escolha de fornecedores e recebimento. É sabido que organismos vivos podem carrear inúmeros agentes patogênicos, que uma vez introduzidos na produção pode comprometer significativamente a saúde de diversas espécies (KENT et al., 2009a; PLOEG; BASSLEER; HENSEN, 2009).

As condições de saúde e bem estar de animais mantidos no estabelecimento devem ser monitorados diariamente pelos tratadores, também responsáveis pelo monitoramento da qualidade de água dos aquários e pelo tratador responsável pela alimentação, todos mantidos sob a supervisão do Médico Veterinário responsável técnico que deverá ser comunicado caso haja alguma ocorrência que possa causar problemas. Cabe ao RT fazer a verificação do cumprimento de todas as práticas diárias de trabalho e daquelas relativas ao monitoramento dos parâmetros de controle (figura 19a).

Recomenda-se também que uma amostra representativa de pele e brânquias sejam analisadas(figura 19b) com objetivo de verificar a prevalência de determinados agentes patogênicos, que quando presentes, devem receber tratamento específico. Amostras de animais que tiveram altas taxas de mortalidade sem causa definida devem ser encaminhados para laboratórios de confiança para diagnóstico mais apurado e monitoramento mais preciso dos agentes envolvidos na patogênese dos animais (NOGA, 2010a). 
Figura 19 : (a) Inspeção visual das condições de saúde dos animais pelo Médico Veterinário; (b) Raspado de pele de peixe ornamental com sintomatologia clínica. Realização de exame microscópico e envio de material para diagnóstico laboratorial

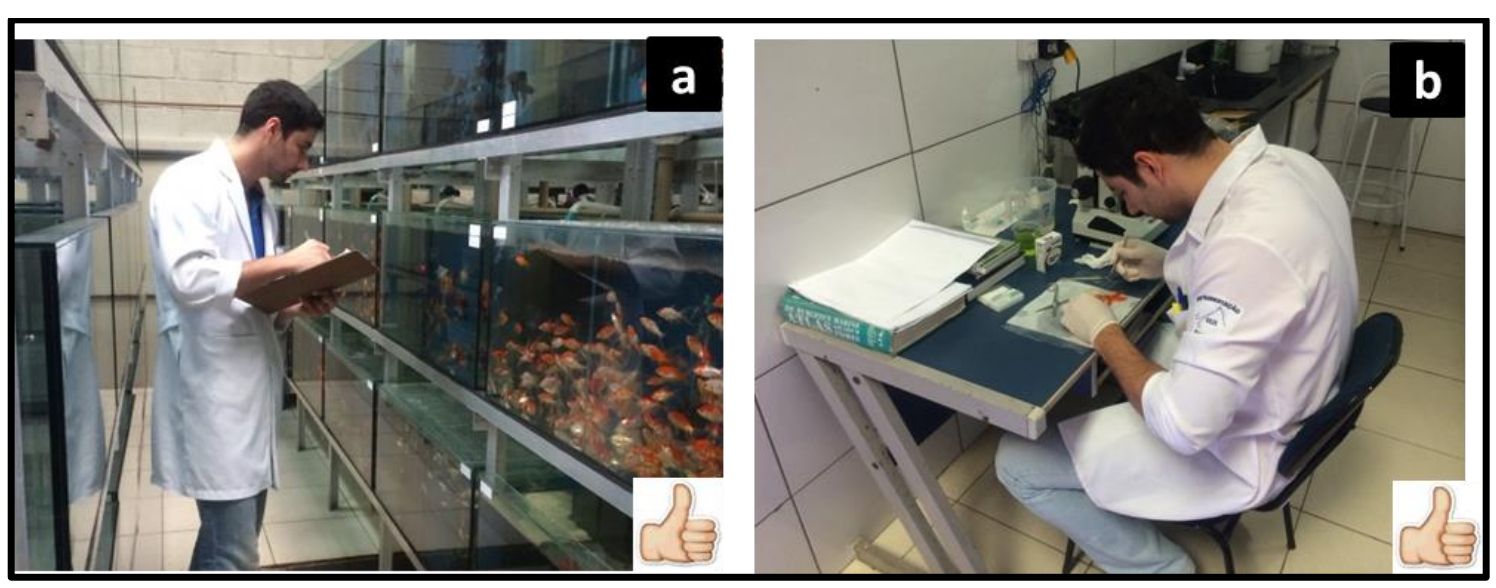

Fonte: Cardoso, 2016

Perante qualquer comportamento anormal de natação e respiração dos peixes identificada pelos colaboradores (figura 20a) ou mesmo a percepção de lesões, estruturas estranhas no corpo dos animais ou deformações, o Médico Veterinário deve ser imediatamente comunicado. Este deve orientar os colaboradores sobre as medidas a serem tomadas com relação a todo o lote de animais afetados.

As medidas profiláticas e de controle podem incluir: a) monitoramento da qualidade de água, b) isolamento dos animais para tratamento, c) coleta de amostras para diagnóstico laboratorial externo (figura 20b) e d) em caso de suspeita de doenças de notificação obrigatória comunicação aos órgãos oficiais executores de sanidade animal(BRASIL, 2003).

Figura 20 - (a) Piranhas vermelhas (Pygocentrus natteri) apresentando nado irregular e movimentos de rodopio após terem sido alimentadas com alimento vivo. Posteriormente, foi diagnosticado a presença de Megalocitivirus sp; (b) Necrópsia de peixe ornamental doente para coleta de órgãos frescos para diagnóstico laboratorial

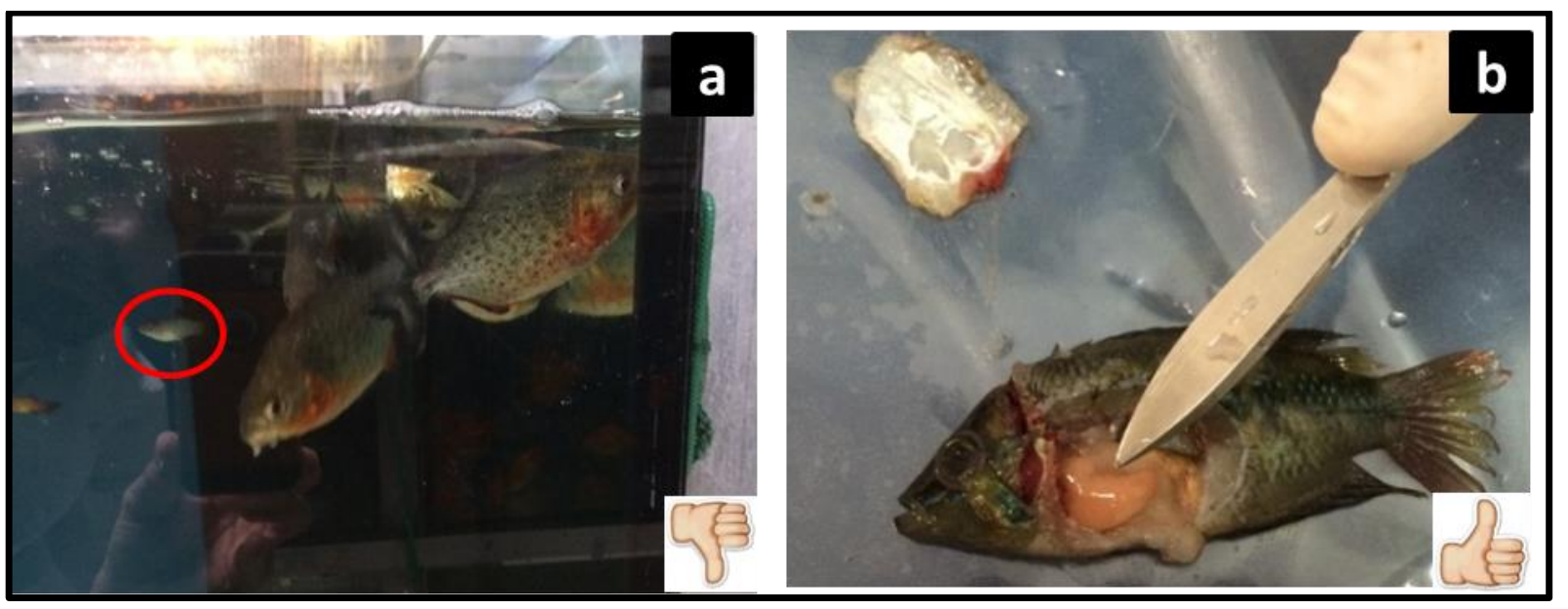

Fonte: Cardoso, 2016 
Os animais são considerados aptos para serem comercializados quando expressam comportamento esperado para a espécie, alimentam-se normalmente com ração processada, não expressam sinais clínicos de doenças e gozam de estado sanitário satisfatório.

Peixes que serão transportados devem ser privados de alimentação por cerca de 24 horas antes da hora programada para a viagem com intuito de diminuir as possibilidades de perda de qualidade de água em decorrência do metabolismo e excreção. Em experimentos utilizando Guppies (Poecilia reticulata) como modelo de estudos, a taxa de sobrevivência após viagem foi maior em animais privados de alimentação por 24 horas em relação às aqueles privados por 12h ou mantidos por mais de 48 horas (LIM; DHERT; SORGELOOS, 2003).

\subsubsection{Captura}

Os peixes vendidos devem ser capturados cuidadosa e delicadamente nos aquários de modo a causar o mínimo de estresse possível tanto nos peixes capturados quando naqueles mantidos no aquário.

Os utensílios (redes, canecas, etc.) utilizados para a pesca devem ser mantidos rigorosamente exclusivos para cada um dos aquários e/ou baterias de aquários. Para tanto, todos utensílios devem ser identificados (figura 21a e 21b) evitando contaminação cruzada com agentes de natureza bacteriana, viral, fúngica e parasitária entre os sistemas aquáticos (aquário/bateria) (OATA, 2006).

Após a utilização devem ser corretamente higienizados (limpeza e desinfecção) com produtos próprios para uso em aquicultura (OIE, 2012). 
Figura 21: (a) Utensílios sem identificação; (b) Utensílios corretamente identificados, assegurando o uso individualizado por aquário ou bateria.

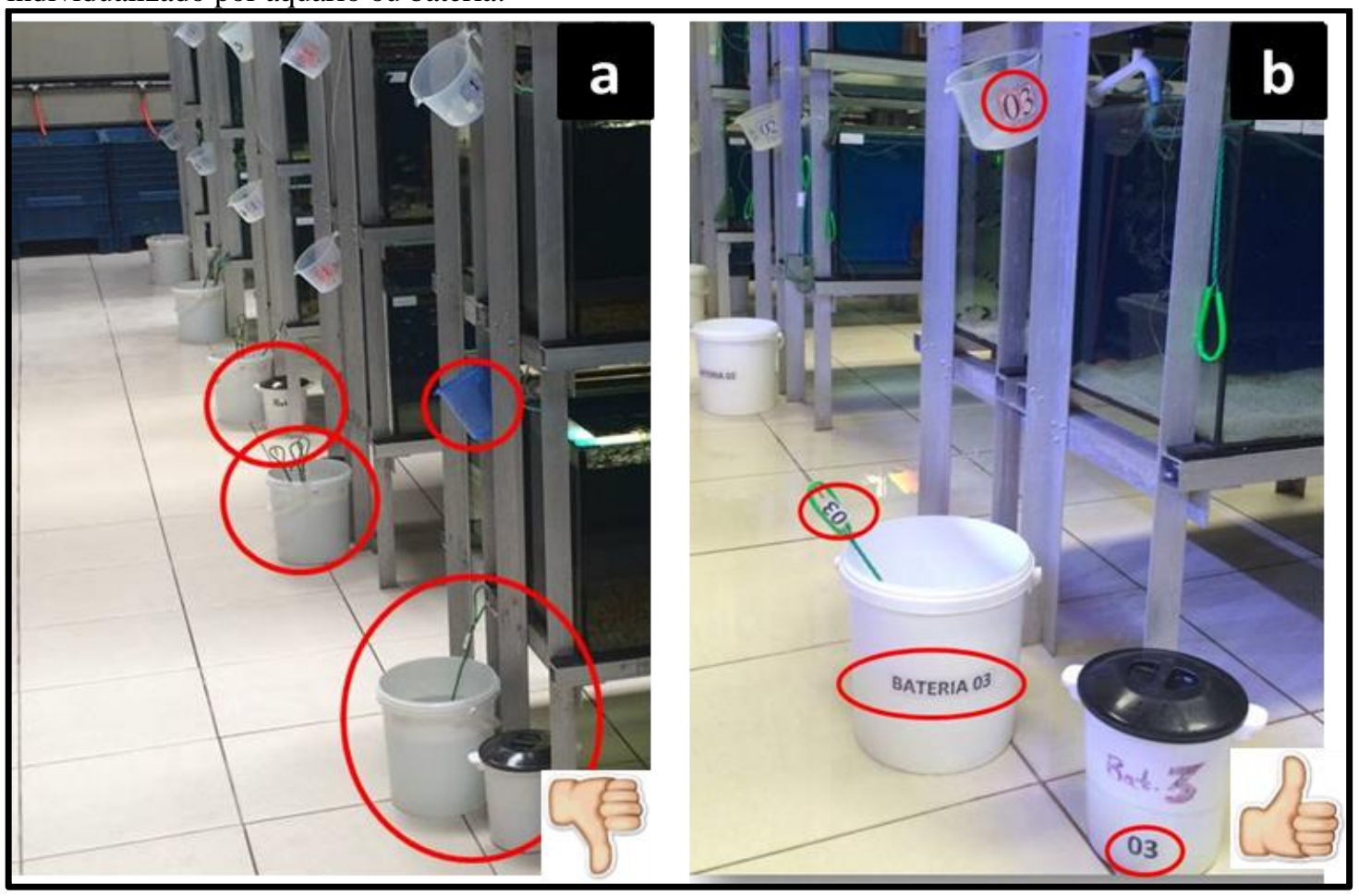

Fonte: Cardoso, 2016

\subsubsection{Embalagem}

Os peixes pescados devem imediatamente alojados em sacos de polietileno (sacos plásticos) limpos e transparentes, próprios e resistentes ao transporte (BRASIL, 2015a) com água (figura 22a), e produto condicionador para reduzir o estresse, oxigenação adequada ao tempo de viagem, lacrados e então inspecionados pelo coordenador que deve certificar que o animais estão em condições físicas e sanitárias satisfatórias para serem comercializados. Estando todos aptos são então etiquetados com informações relativas à espécie, ao número de animais e pH da água quando da embalagem (figura 22b).

A água e oxigenação utilizados no transporte devem ser suficientes para o período estimado da viagem de modo a garantir o máximo de qualidade possível e não causar prejuízos aos peixes em decorrência do acúmulo de metabólitos como amônia e dióxido de carbono (LIM; DHERT; SORGELOOS, 2003). 
Figura 22: (a) Embalagem de peixes ornamentais em saco polietileno (saco plástico); (b) Identificação dos peixes ornamentais após embalagem.

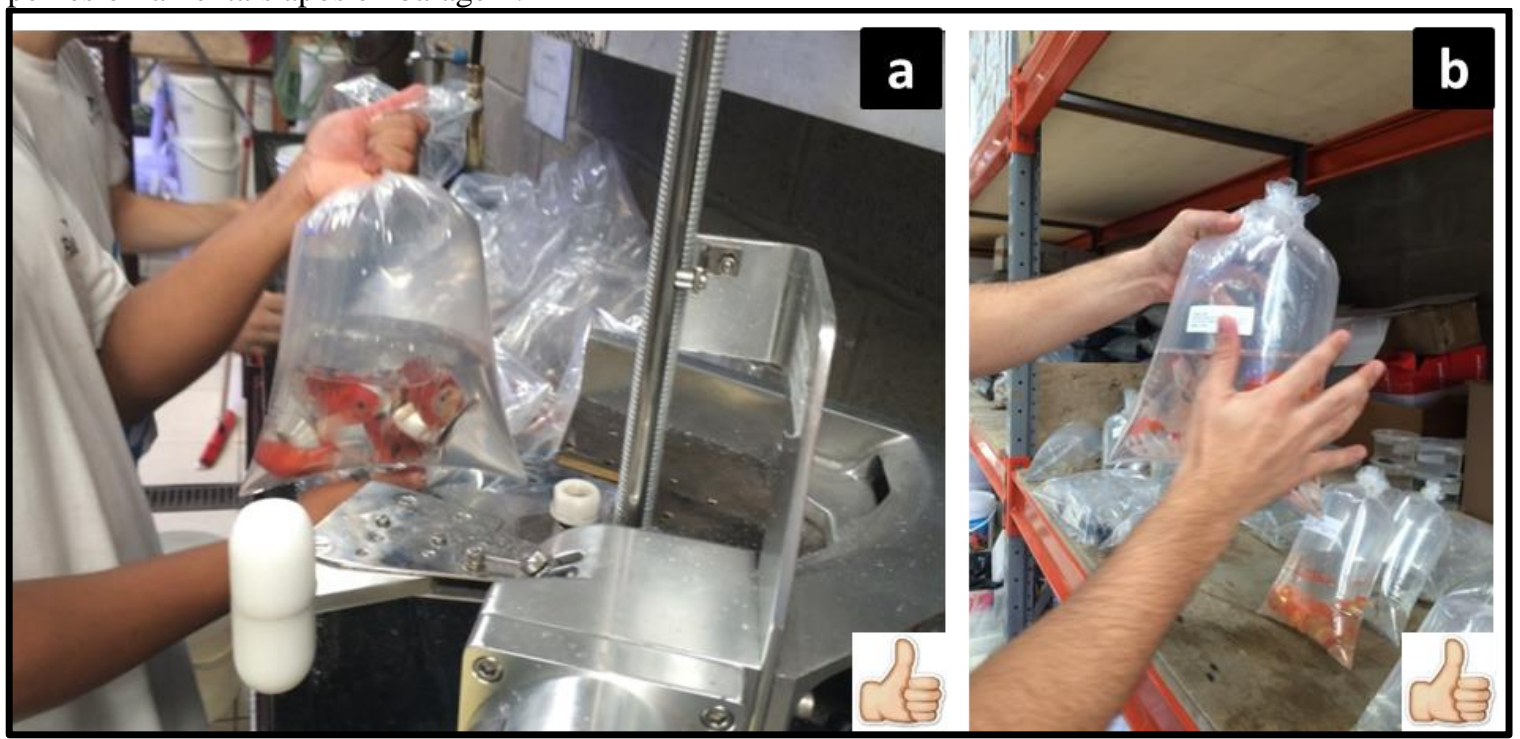

Fonte: Cardoso, 2016

\subsubsection{Transporte/ Distribuição}

As embalagens devem ser acondicionadas em caixas de poliestireno [isopor] (figura 23a) e lacradas com fita adesiva (figura 23b) para que não haja variação de temperatura durante o transporte. Este é um cuidado bastante importante e crítico para a manutenção do bom estado sanitário e de conforto dos peixes durante o transporte. As variações de temperatura alteram o metabolismo dos animais, e por consequência, diminui a concentração de oxigênio dissolvido na água, gerando situação de estresse e consequentemente depressão do sistema imunológico, levando ao aumento da suscetibilidade à doenças (DAVIS; GRIFFIN; GRAY, 2002; BRINN et al., 2012; DHANASIRI; FERNANDES; KIRON, 2013; CROSBY et al., 2014; OIE, 2014a). 
Figura 23: (a) Após embalados e conferidos, peixes ornamentais são armazenados em caixas de poliestireno (isopor); (b) Caixa de poliestireno (isopor) lacradas e prontas para serem despachadas para o comércio varejista.

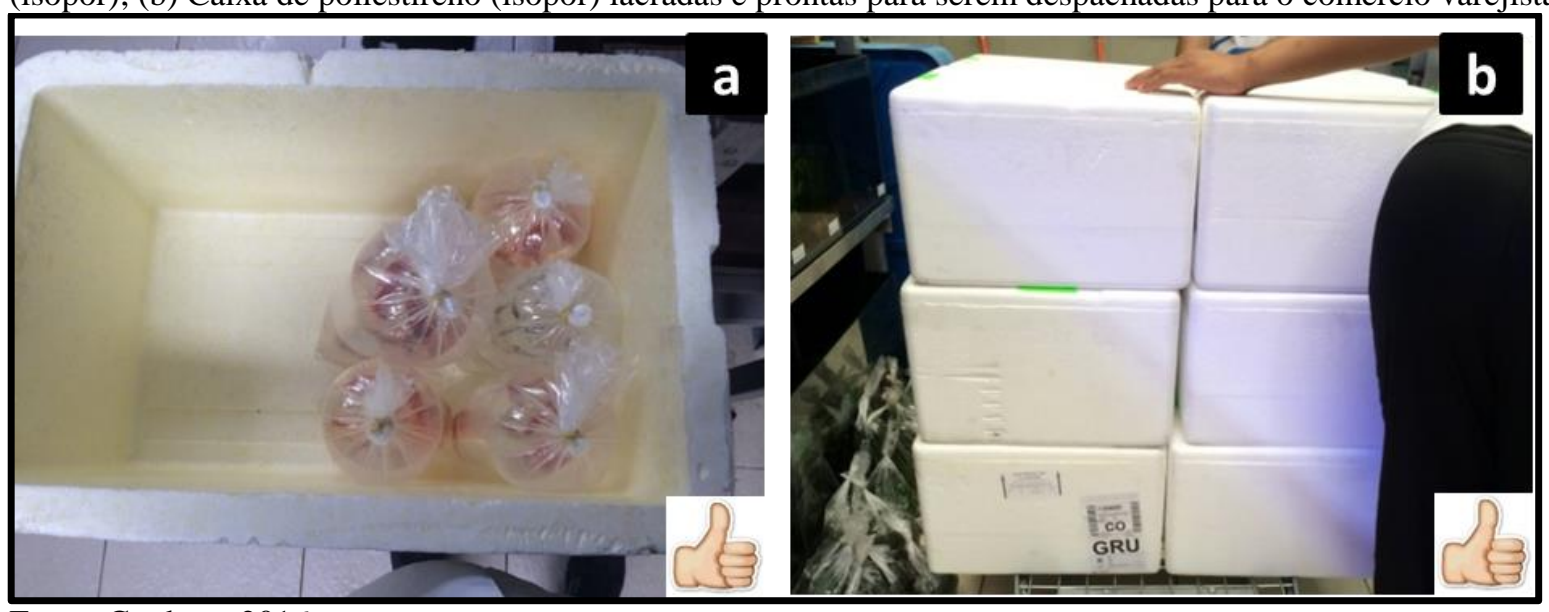

Fonte: Cardoso, 2016 


\subsection{CONSIDERAÇÕES FINAIS}

Para que um estabelecimento atacadista de peixes ornamentais tenha um nível aceitável de biosseguridade e ofereça animais em estado sanitário satisfatório é importante que haja descrição de todas as práticas que são feitas no estabelecimento, gerando dessa forma o processo de autocontrole.

O âmbito de aplicação das boas práticas deve ser definido e tudo deve estar escrito no manual de boas práticas da empresa, bem como as funções de todas as pessoas envolvidas diretamente com os animais, incluindo-se o motorista dos veículos de transporte, operadores de rotinas com os aquários, RT, pessoal responsável pela higienização de equipamentos e utensílios entre outros.

As condições de infraestrutura e higiênicossanitárias devem manter elevado padrão de conformidade com as especificações técnicas e o manual de boas práticas do estabelecimento, de modo a não oferecer risco para os trabalhadores e os animais. As edificações devem ser construídas de modo a facilitar o manejo, manter fluxo o mais linear possível para a sequencia lógica dos procedimentos, reduzir o acúmulo de água e sujidades, possibilitar práticas higiênicas e manutenções diárias, de modo que não haja disseminação de doenças de um sítio para outro.

A adoção de um sistema de controle de qualidade é primordial e vital para a sobrevivência e sustentabilidade do estabelecimento. O controle de qualidade deve abarcar desde a água utilizada nos aquários para manter os animais, até ações adotadas para animais que por ventura adoeçam, incluindo-se a capacitação e treinamento constante dos trabalhadores.

O fluxograma de funcionamento desde o recebimento até o transporte dos animais para distribuição deve ser cuidadosamente descrito e corretamente cumprido pelos colaboradores envolvidos, garantindo as melhores condições para que os animais cheguem saudáveis até os consumidores.

Portanto, esse guia oferece subsídios genéricos para a aplicação de procedimentos relacionados às boas práticas de manejo, higiene, processos e Bem Estar Animal (que compõem parte dos programas de autocontrole) com o intuito de diminuir a possibilidade de introdução e/ou disseminação de doenças, preservando um bom "status" sanitário dos animais comercializados para usufruto dos consumidores. 


\section{REFERÊNCIAS}

ABINPET. Dados de Mercado. Associação Brasileira da Indústria de produtos para Animais de Estimação.

ALMEIDA, C. R.; RASZL, S. M.; ORE, N. D. B.; JÚNIOR, G. A. da C. Boas práticas agrícolas (GAP) e Boas práticas de fabricação (GMP)Buenos Aires, ArgentinaOrganização Pan-americana de Saúde, , 2005. .

ALTINOK, I. Toxicity and therapeutic effects of chloramine-T for treating Flavobacterium columnare infection of goldfish. Aquaculture, v. 239, n. 1-4, p. 47-56, 2004.

ANATOLE, H.; BOSCH, T. M. Diagnóstico Geral das práticas de cotrole ligadas a exploração, captura, comercialização, exportação e uso de peixes para fins ornamentais e de aquariofilia Brasília IBAMA, 2008. .

ARAÚJO, A. P.; PÉREZ, A. C. A. O médico veterinário e o comércio de peixes ornamentais. Rev. Educ. Contin., v. 8, n. 2, p. 176-186, 2005.

ARVANITOYANNIS, I. S.; VARZAKAS, T. H. Application of ISO 22000 and Failure Mode and Effect Analysis (FMEA) for industrial processing of salmon: a case study. Critical Reviews in Food Science and Nutrition, v. 48, n. April 2015, p. 411-429, 2008.

BERAN, V.; MATLOVA, L.; DVORSKA, L.; SVASTOVA, P.; PAVLIK, I. Distribution of mycobacteria in clinically healthy ornamental fish and their aquarium environment. Journal of Fish Diseases, v. 29, p. 383-393, 2006.

BERTINI, B.; MENDES., F. Segurança dos alimentos no comércio - atacado e varejo. Rio de Janeiro: Senac, 2011.

BRASIL. Instrução Normativa $N^{\circ} 39$, de 4 de novembro de 1999. Ministério da Agricultura Pecuária e AbastecimentoDiário Oficial [da] União, Brasília, DF, 08 de nov. de 1999, 1999.

BRASIL. Instrução Normativa $\mathbf{N}^{\circ} 53$, de 2 de junho de 2003. Ministério da Agricultura Pecuária e AbastecimentoDiário Oficial [da] União, Brasília, 04 de jul. de 2003.

BRASIL. Instrução Normativa Ibama $\mathbf{N}^{\mathbf{0}}$ 96, de 30 de março. Atividades nas categorias do Cadastro Técnico Federal de Atividades Potencialmente poluidoras ou utilizadoras 
de Recursos Ambientais.Diário Oficial [da] União, Brasília, 31 de mar. 2006.

BRASIL. Instrução Normativa $\mathrm{N}^{\mathbf{0}}$ 18, de 13 de maio de 2008. Ministério da Agricultura Pecuária e Abastecimento.Diário Oficial [da] União, Brasília, DF, 15 de mai. 2008., Brasil Ministério da Agricultura Pecuária e Abastecimento, , 2008a.

BRASIL. Instrução Normativa $\mathbf{N}^{0} 202$ de 22 de outubro de 2008. Instituto Brasileiro do Meio Ambiente e dos Recursos Naturais Renováveis (IBAMA).Diário Oficial [da] União, Brasília, DF, 2008b.

BRASIL. Instrução Normativa $\mathrm{N}^{0}$ 18, de 13 de maio de 2008. Ministério da Agricultura Pecuária e Abastecimento.Diário Oficial [da] União, Brasília, DF, 14 mai. de 2008, 2008c.

BRASIL. Instrução Normativa N6 de 19 de maio. Dispoe sobre o Registro e a Licença de AquicultorDiário Oficial [da] União,Brasília, 20 de mai. de 2015, 2011.

BRASIL. Instrução Normativa Interministerial $n^{0} 001$, de 3 de janeiro de 2012. Ministério da Pesca e Aquicultura e Ministério do Estado do Meio AmbienteDiário Oficial [da] União, Brasília, DF, 2012.

BRASIL. Instrução normativa $\mathrm{N}^{\circ} 17$ de 11 de agosto de 2014. Ministério da Pesca e Aquicutura.Diário Oficial [da] União,Brasília, DF, 13 de agos. de 2014, 2014.

BRASIL. Instrução Normativa $n^{0}$ 4, de 4 de fevereiro de 2015. Ministério da Pesca e AquiculturaDiário Oficial [da] União, Brasília, DF, 09 de fev de 2015, Brasil Ministério da Pesca e Aquicultura, , 2015.

BRASIL, M. da A. P. e A. Portaria $\mathbf{N}^{\mathbf{0}}$ 99. Regimento Interno da Secretaria de Defesa Agropecuária.Brasilia, DF, 12 de maio de 2016Diário Oficial da União, , 2016.

BRASIL, M. da A. P. e A. Decreto $\mathbf{N}^{0}$ 9.013. Regulamento da Inspeção Industrial e Sanitária de Produtos de Origem Animal. Brasilia, DF, 29 de março de 2017Diário Oficial da União, , 2017. .

BRASIL, M. da S. Resolução RDC No 306Ministério da Saúde Agência Nacional de Vigilância SanitáriaBrasilia, DF, 7 de dezembro de 2004Diário Oficial da União, , 2004.

BRASIL, M. do T. e E. Nr 7 - Programa De Controle Médico De Saúde

Ocupacional(Portaria GM no 3.214, de 08 de junho de 1978 Brasilia, DF Diário Oficial da 
União, , 1978a.

BRASIL, M. do T. e E. NR 6 - Equipamento de Proteção Individual (Portaria GM no 3.214, de 08 de junho de 1978) Brasilia, DFDiário Oficial da União, , 1978b. .

BRASIL, M. do T. e E. NR 31 - Segurança e Saúde no Trabalho na Agricultura, Pecuária, Silvicultura, Exploração Florestal e Aquicultura (Portaria MTE n⿳0 86, de 03 de março de 2005) Brasilia, DF Diário Oficial da União,2005. .

BRINN, R. P.; MARCON, J. L.; MCCOMB, D. M.; GOMES, L. C.; ABREU, J. S.; BALDISSEROTO, B. Stress responses of the endemic freshwater cururu stingray (Potamotrygon cf. histrix) during transportation in the Amazon region of the Rio Negro. Comparative biochemistry and physiology. Part A, Molecular \& integrative physiology, v. 162, n. 2, p. 139-45, jun. 2012.

CHEUNG, J.; FUNG, B.; IP, W.; CHOW, S.-P. Mycobacterium marinum infection of the hand and wrist. Journal of Orthopaedic Surgery, v. 20, n. 2, p. 214-218, 2012.

CODEX ALIMENTARIUS COMMISSION. General Principles of Food Hygiene. Codex Alimentarius - Basic Texts Food Hygiene, p. 21-31, 2003.

CROSBY, T. C.; HILL, J. E.; MARTINEZ, C. V; WATSON, C. a; POUDER, D. B.; ROY, P. E. On-Farm Transport of Ornamental Fish 1. IFAS Extension Univserity of Florida, v. FA119, p. 1-6, 2014.

DANIEL, H.; MARCOS, R.; AMORIM, D. S.; ALBERTO, J.; ROCHA, C. Exportação De Peixes Ornamentais Do Estado Do Amazonas , Bacia Ornamental Fish Export of the State of Amazonas , Amazon Basin ,. Boletim do Instituto de Pesca, v. 35, n. 2, p. 259-274, 2009.

DAVIS, K. B.; GRIFFIN, B. R.; GRAY, W. L. Effect of handling stress on susceptibility of channel catfish Ictalurus punctatus to Ichthyophthirius multifiliis and channel catfish virus infection. Aquaculture, v. 214, n. 1-4, p. 55-66, nov. 2002.

DHANASIRI, A. K. S.; FERNANDES, J. M. O.; KIRON, V. Acclimation of zebrafish to transport stress. Zebrafish, v. 10, n. 1, p. 87-98, mar. 2013.

E.J, F. A. L.; CHAPMAN. The Ornamental Fish Trade: An Introduction with Perspectives for Responsible Aquarium Fish Ownership, 2014. . 
FAO. Aquatic Biossecurity: a key for sustainable aquaculture development. In: Committee on Fisheries. [s.1: s.n.]p. 1-12.

FOSSA, S. A.; BASSLEER, G. M. O.; CHUAN, L. L.; PLOEG, A. International Transport of Live Fish in the Ornamental Aquatic Industry NetherlandsOrnamental Fish International (OFI), , 2007. .

FOSSA, S. A.; BASSLEER, G. M. O.; CHUAN, L. L.; PLOEG, A. Biossecurity in the Ornamental Aquatic Industry. [s.l: s.n.]

FULDE, M.; VALENTIN-WEIGAND, P. Epidemiology and pathogenicity of zoonotic streptococci. Current Topics in Microbiology and Immunology, v. 368, p. 49-81, jan. 2013.

GAIKOWSKI, M. P.; LARSON, W. J.; STEUER, J. J.; GINGERICH, W. H. Validation of two dilution models to predict chloramine-T concentrations in aquaculture facility effluent. Aquacultural Engineering, v. 30, n. 3-4, p. 127-140, 2004.

GAUTHIER, D. T. Bacterial zoonoses of fishes: A review and appraisal of evidence for linkages between fish and human infections. The Veterinary Journal, v. 203, n. 1, p. 27-35, 2015.

KENT, M. L.; FEIST, S. W.; HARPER, C.; HOOGSTRATEN-MILLER, S.; LAW, J. Mac; SÁNCHEZ-MORGADO, J. M.; TANGUAY, R. L.; SANDERS, G. E.; SPITSBERGEN, J. M.; WHIPPS, C. M. Recommendations for control of pathogens and infectious diseases in fish research facilities. Comparative Biochemistry and Physiology - C Toxicology and Pharmacology, v. 149, p. 240-248, 2009.

KUBITZA, F. Sistemas de recirculação: sistemas fechados com tratamento e reuso da água. Panorama da Aquiicultura, v. Maio/Junho, p. 15-22, 2006.

LEHANE, L.; RAWLIN, G. T. Topically acquired bacterial zoonoses from fish: a review. Medical journal of Australia, v. 173, n. 5, p. 256-9, set. 2000.

LIM, L. C.; DHERT, P.; SORGELOOS, P. Recent developments and improvements in ornamental fish packaging systems for air transport. Aquaculture Research, v. 34, n. 11, p. 923-935, set. 2003.

LOWRY, T.; SMITH, S. A. Vet Med Today: Zoonosis Update. v. 231, n. 6, p. 876-880, 
2007.

MONDAL, S.; RAHMAN, M. M.; SAHA, D.; ADHIKARY, R. K.; HOSSAIN, M. B. Present Status of Good Aquaculture Practices ( GAP) in Shrimp Farms of South-Western Coastal Area , Bangladesh. Middle-East Journal of Scientific Research, v. 14, n. 6, p. 873-878, 2013.

NOGA, E. J. Fish disease: diagnosis and treatment. Second ed. Ames, Iowa, USA: Willey, 2010.

OATA, O. A. T. A. Biossecurity and the ornamental fish industry. [s.l: s.n.].

OIE. Welfare of farmed fish during transport. In: Aquatic Animal Heath Code. [s.l: s.n.]p. $2-5$.

OIE, W. O. for A. H. Methods for Disinfection of Aquaculture Establishments. In: Manual of Diagnostic Tests for Aquatic Animals 2014. [s.l: s.n.]p. 28-40.

PLOEG, A.; BASSLEER, G. M. O.; HENSEN, R. R. Biossecurity in the Ornamental Aquatic IndustryNetherlands, 2009. .

PREARO, M.; ZANONI, R. G.; CAMPO DALL\&APOS;ORTO, B.; PAVOLETTI, E.; FLORIO, D.; PENATI, V.; GHITTINO, C. Mycobacterioses: Emerging pathologies in aquarium fish. Veterinary Research Communications, v. 28, n. July 2001, p. 315-317, 2004.

REILLY, A.; KAFERSTEIN, F. Food safety hazards and the application of the principles of the hazard analysis and critical control point (HACCP) system for their control in aquaculture production. Aquaculture Research, v. 28, n. 1994, p. 735-752, 1997.

ROSE, S.; HILL, R.; BERMUDEZ, L. E.; MILLER-MORGAN, T. Imported ornamental fish are colonized with antibiotic-resistant bacteria. Journal of fish diseases, v. 36, n. 6, p. 53342, jun. 2013. SENAC. Guia de Elaboração do Plano APPCC Guia de Elaboração do Plano APPCCRio de Janeiro, 2001. .

SHARRER, M. J.; SUMMERFELT, S. T. Ozonation followed by ultraviolet irradiation provides effective bacteria inactivation in a freshwater recirculating system. Aquacultural Engineering, v. 37, n. 2, p. 180-191, 2007. 
SILVA JUNIOR, E. A. D. Manual de controle higiênico sanitário em serviços de alimentação. $6^{\text {a }}$ edição ed. São Paulo: Varela, 2014.

SMAIL, D. A.; GRANT, R.; SIMPSON, D.; BAIN, N.; HASTINGS, T. S. Disinfectants against cultured Infectious Salmon Anaemia (ISA) virus: The virucidal effect of three iodophors, chloramine $\mathrm{T}$, chlorine dioxide and peracetic acid/hydrogen peroxide/acetic acid mixture. Aquaculture, v. 240, n. 1-4, p. 29-38, 2004.

TANGO, M. S.; GAGNON, G. a. Impact of ozonation on water quality in marine recirculation systems. Aquacultural Engineering, v. 29, p. 125-137, 2003.

TOOKWINAS, S.; KEERATIVIRIYAPORN, S. HACCP in shrimp farming. Acquaculture Asia, v. 9, n. 2, p. 29-33, 2004.

TRUST, T. J.; BARTLETT, K. H. Occurrence of potential pathogens in water containing ornamental fishes. Applied Microbiology, v. 28, n. 1, p. 35-40, jul. 1974.

TRUST, T. J.; WHITBY, J. L. Antibiotic resistance of bacteria in water containing ornamental fishes. Antimicrob Agents Chemother, v. 10, n. 4, p. 598-603, 1976.

VERNER-JEFFREYS, D. W.; WELCH, T. J.; SCHWARZ, T.; POND, M. J.; WOODWARD, M. J.; HAIG, S. J.; RIMMER, G. S. E.; ROBERTS, E.; MORRISON, V.; BAKER-AUSTIN, C. High prevalence of multidrug-tolerant bacteria and associated antimicrobial resistance genes isolated from ornamental fish and their carriage water. PloS One, v. 4, n. 12, p. e8388, jan. 2009.

WEIR, M.; RAJIĆ, A.; DUTIL, L.; CERNICCHIARO, N.; UHLAND, F. C.; MERCIER, B.; TUŠEVLJAK, N. Zoonotic bacteria, antimicrobial use and antimicrobial resistance in ornamental fish: a systematic review of the existing research and survey of aquaculture-allied professionals. Epidemiology and Infection, v. 140, n. 2, p. 192-206, 2012.

WHITTINGTON, R. J.; CHONG, R. Global trade in ornamental fish from an Australian perspective: the case for revised import risk analysis and management strategies. Preventive veterinary medicine, v. 81, n. 1-3, p. 92-116, 14 set. 2007. Disponível em: YANONG, R. P. E. Cryptocaryon irritans Infections ( Marine White Spot Disease ) in Fish. IFAS Extension Univserity of Florida, v. FA164, p. 1-9, 2009.

YOUNG-MOK, K.; MYUNG-SUK, L.; TAE-JIN, K.; YONG-HYUN, C. Study on 
Considering Points to Introcuce the HACCP Programs and Surveying at Aquaculture Farm of Rainbow Trout. v. 24, n. 2, p. 224-233, 2012. 


\section{APÊNDICES}

Apêndice 1

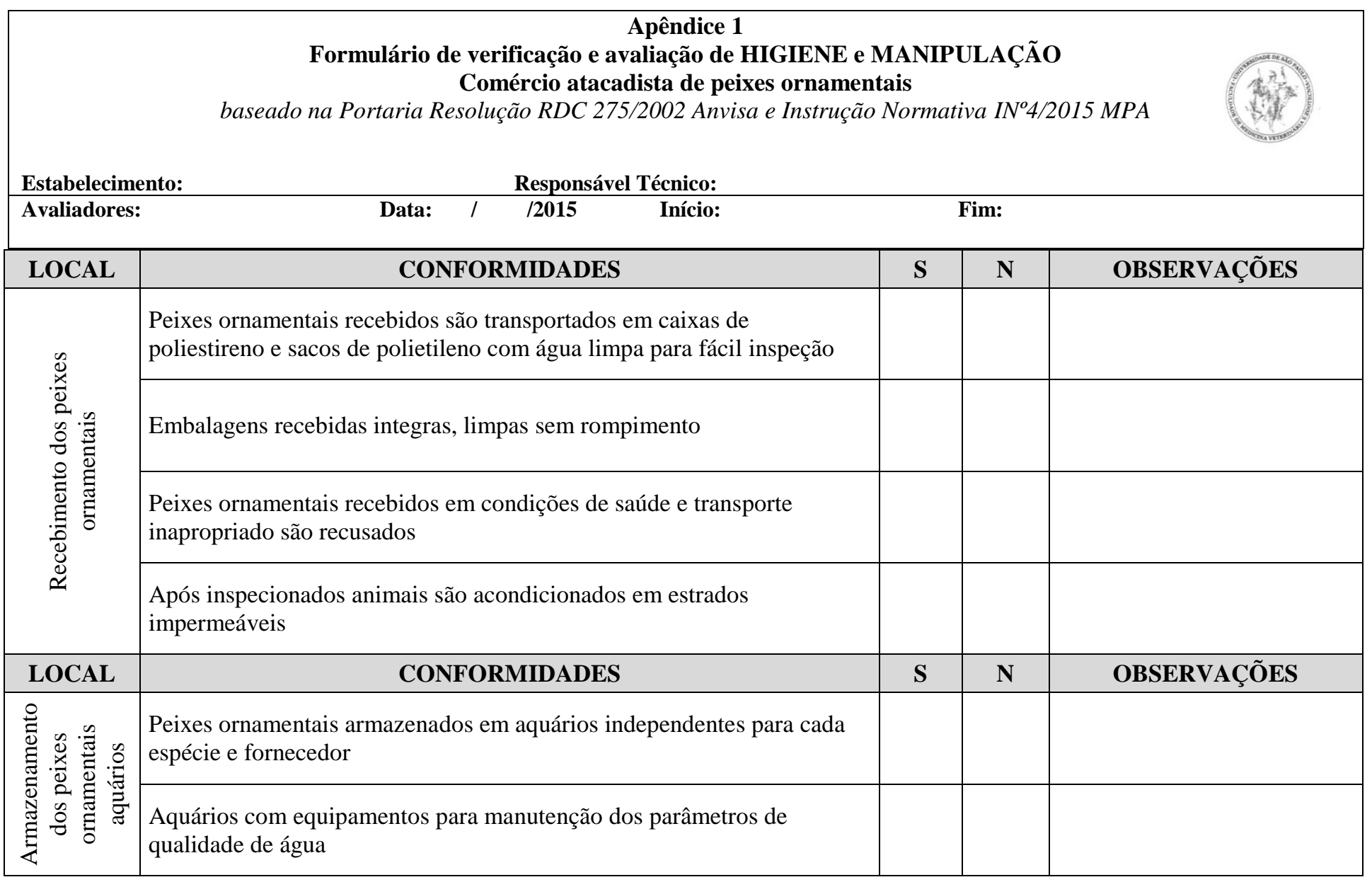




\begin{tabular}{|c|c|c|c|c|}
\hline & Aquários identificados com cada espécie e parâmetro ideal & & & \\
\hline & Tratamento preventivo de animais recém adquiridos & & & \\
\hline & $\begin{array}{l}\text { Monitoramento dos parâmetros de qualidade de água no mínimo um vez } \\
\text { por semana }\end{array}$ & & & \\
\hline & Não existem materiais estranhos e /ou de uso pessoal no local & & & \\
\hline & $\begin{array}{l}\text { Animais alimentados com produtos regulamentados pelo Ministério da } \\
\text { Agricultura Pecuária e Abastecimento (repito isso na parte manipulação). }\end{array}$ & & & \\
\hline LOCAL & CONFORMIDADES & $\mathbf{S}$ & $\mathbf{N}$ & OBSERVAÇÕES \\
\hline \multirow{6}{*}{ 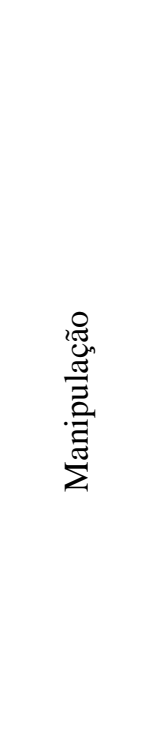 } & $\begin{array}{l}\text { As instalações e dependências são identificadas de modo a propiciar um } \\
\text { fluxo lógico de trabalho }\end{array}$ & & & \\
\hline & Dispõe de redes de captura e manuseio distintos para cada aquário & & & \\
\hline & Dispõe de utensílios distintos para cada aquário & & & \\
\hline & $\begin{array}{l}\text { Peixes recebem alimentação balanceada e são observados durante todo o } \\
\text { período que estão sendo alimentados. }\end{array}$ & & & \\
\hline & $\begin{array}{l}\text { Redes de captura são higienizadas após o uso e com produto } \\
\text { regulamentado pelo MAPA. }\end{array}$ & & & \\
\hline & $\begin{array}{l}\text { Produtos usados na alimentação são industrializados e possuem registro } \\
\text { no MAPA. }\end{array}$ & & & \\
\hline
\end{tabular}




\begin{tabular}{|c|c|c|c|c|}
\hline & Realiza higienização e desinfecção dos utensílios após o uso & & & \\
\hline & Não reaproveita recipientes descartáveis & & & \\
\hline & Não são usados panos ou tecidos para secagem de mãos e/ou utensílios & & & \\
\hline & $\begin{array}{l}\text { Realiza manutenção dos aquários sempre que precisa ou quando os } \\
\text { parâmetros de qualidade de água estão fora do padrão regular }\end{array}$ & & & \\
\hline & $\begin{array}{l}\text { Lixo depositado em sacos plásticos apropriados, e removidos } \\
\text { periodicamente. }\end{array}$ & & & \\
\hline & $\begin{array}{l}\text { Animais mortos depositados em sacos plásticos brancos leitoso para } \\
\text { recolhimento por empresa coletora; }\end{array}$ & & & \\
\hline & Uniformes estão sempre limpos & & & \\
\hline & Manipuladores seguem asseios de Higienização & & & \\
\hline LOCAL & CONFORMIDADES & $\mathbf{S}$ & $\mathbf{N}$ & OBSERVAÇÕES \\
\hline 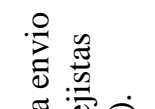 & $\begin{array}{l}\text { Peixes ornamentais acondicionados previamente à embalagem em } \\
\text { recipientes higienizados }\end{array}$ & & & \\
\hline 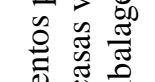 & Peixes ornamentais embalados com água limpa e oxigênio suficiente & & & \\
\hline 造 & Disposição de peixes por categoria (espécies) & & & \\
\hline
\end{tabular}




\begin{tabular}{|c|c|c|c|c|}
\hline & $\begin{array}{l}\text { As embalagens dos peixes ornamentais são limpas, íntegras, com rótulo e } \\
\text { de fácil inspeção }\end{array}$ & & & \\
\hline & $\begin{array}{l}\text { Peixes identificados na embalagem e prontos para serem acondicionados } \\
\text { em novos aquários }\end{array}$ & & & \\
\hline & Peixes armazenados sem contato direto com chão & & & \\
\hline & Recipientes exclusivos para peixes ornamentais & & & \\
\hline LOCAL & CONFORMIDADES & $\mathbf{S}$ & $\mathbf{N}$ & OBSERVAÇÕES \\
\hline 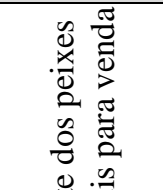 & Embalagens enviadas integras, limpas sem rompimento & & & \\
\hline 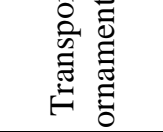 & $\begin{array}{l}\text { Peixes ornamentais despachados da distribuidora são transportados em } \\
\text { caixas de poliestireno e sacos de polietileno com água limpa para fácil } \\
\text { inspeção }\end{array}$ & & & \\
\hline LOCAL & CONFORMIDADES & $\mathbf{S}$ & $\mathbf{N}$ & OBSERVAÇÕES \\
\hline 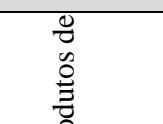 & $\begin{array}{l}\text { Utiliza produtos de limpeza com registro no Ministério da Agricultura } \\
\text { Pecuária e Abastecimento e estão armazenados em local específico }\end{array}$ & & & \\
\hline 焉 & $\begin{array}{l}\text { Utiliza medicamentos com registro no Ministério da Agricultura } \\
\text { Pecuária e Abastecimento e estão armazenados em local específico }\end{array}$ & & & \\
\hline 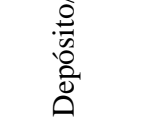 & $\begin{array}{l}\text { Utensílios de limpeza mantidos limpos, bem conservados e em local } \\
\text { especifico }\end{array}$ & & & \\
\hline LOCAL & CONFORMIDADES & $\mathbf{S}$ & $\mathbf{N}$ & OBSERVAÇÕES \\
\hline 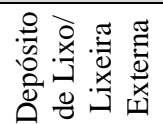 & Resíduos acondicionados em lixeiras com sacos plásticos & & & \\
\hline
\end{tabular}




\begin{tabular}{|l|l|l|l|l|}
\hline Há separação de resíduos secos e orgânicos & & & \\
\hline & O local é periodicamente limpo e desinfetado & & & \\
\hline
\end{tabular}

Observações necessárias:

Assinatura Responsável pelo estabelecimento:

Data: _____ 
Apêndice 2

\begin{tabular}{|c|c|c|c|c|}
\hline \multicolumn{5}{|c|}{$\begin{array}{c}\text { Apêndice } 2 \\
\begin{array}{c}\text { Formulário de verificação e avaliação da INFRAESTRUTURA mínima em comércio atacadista } \\
\text { urbano de peixes ornamentais }\end{array}\end{array}$} \\
\hline LOCAL & CONFORMIDADES & $\mathbf{S}$ & $\mathbf{N}$ & OBSERVAÇÕES \\
\hline 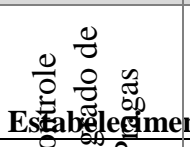 & $\begin{array}{l}\text { IN4/2015 MPA } \\
\text { O estabelecimento adota medidas preventivas de atracãa e } \\
\text { Responsável Técnico: }\end{array}$ & & & \\
\hline Avaliägres: & $\begin{array}{rlll}\text { Data: } & / & / 2015 & \text { Início: }\end{array}$ & & & Fim: \\
\hline LOCAL & CONFORMIDADES & $\mathbf{S}$ & $\mathbf{N}$ & OBSERVAÇÕES \\
\hline 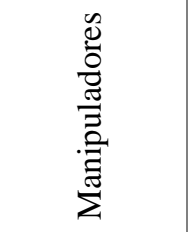 & Faz exames médicos dos colaboradores semestralmente & & & \\
\hline LOCAL & CONFORMIDADES & $\mathbf{S}$ & $\mathbf{N}$ & OBSERVAÇÕES \\
\hline \multirow{4}{*}{ 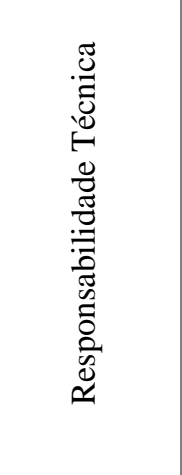 } & $\begin{array}{l}\text { Proprietário ou responsável pelo ponto possui certificado de } \\
\text { curso de BP (verificar documento) }\end{array}$ & & & \\
\hline & $\begin{array}{l}\text { Os colaboradores recebem capacitação sobre BPF (verificar } \\
\text { registros). }\end{array}$ & & & \\
\hline & $\begin{array}{l}\text { Estabelece critérios para compra de peixes ornamentais com } \\
\text { fornecedores registrados no RGP (verificar documento) }\end{array}$ & & & \\
\hline & $\begin{array}{l}\text { Possui planilhas de monitoramento dos principais parâmetros } \\
\text { de água dos aquários }\end{array}$ & & & \\
\hline LOCAL & CONFORMIDADES & $\mathbf{S}$ & $\mathbf{N}$ & OBSERVAÇÕES \\
\hline
\end{tabular}




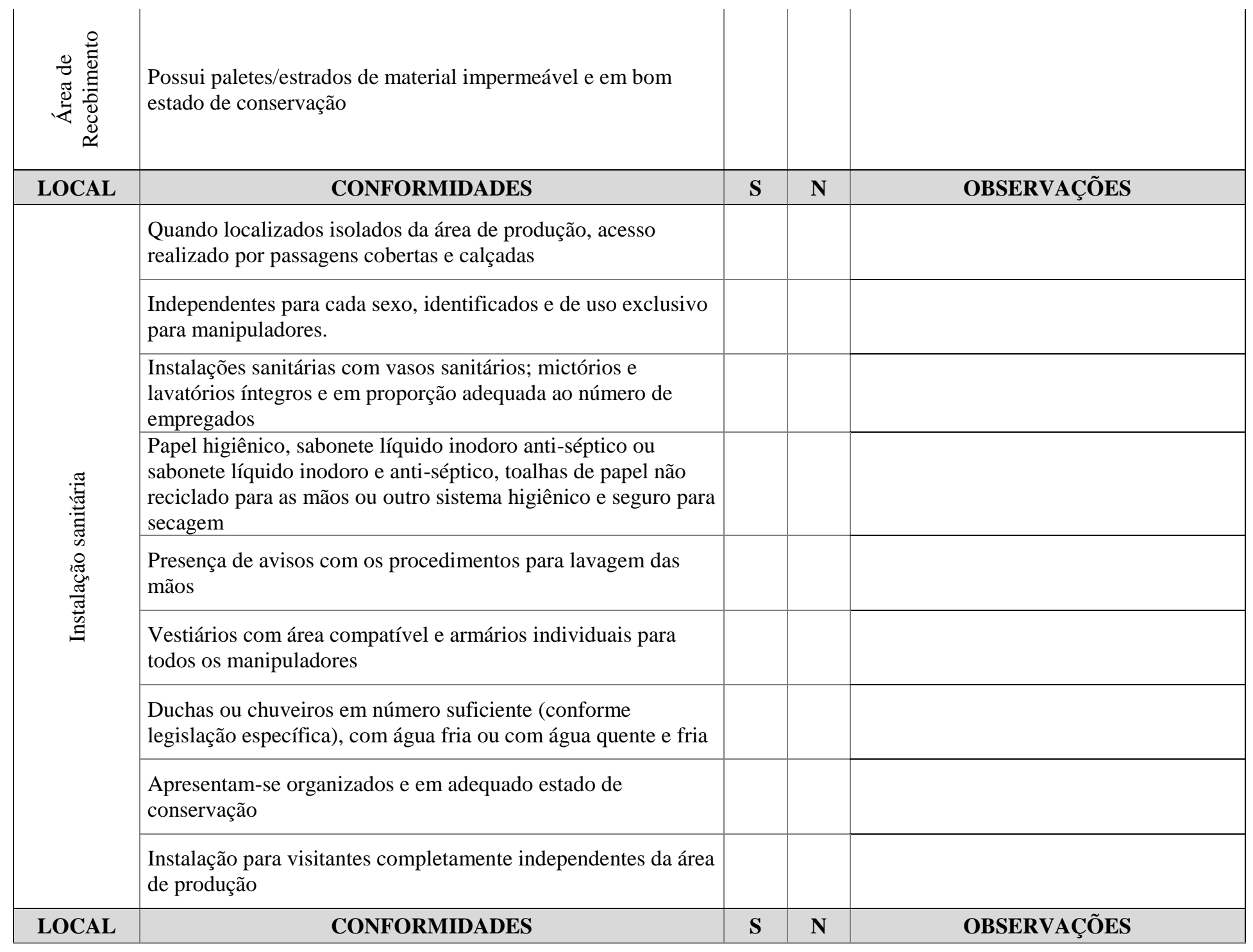




\begin{tabular}{|c|c|c|c|c|}
\hline 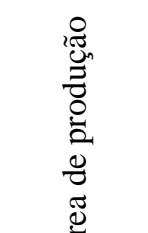 & $\begin{array}{l}\text { Existência de lavatórios na área de manipulação com água } \\
\text { corrente, dotados preferencialmente de torneira com } \\
\text { acionamento automático, em posições adequadas em relação ao } \\
\text { fluxo de produção e serviço, e em número suficiente de modo a } \\
\text { atender toda a área de produção }\end{array}$ & & & \\
\hline 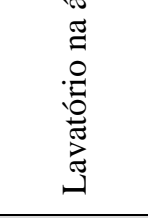 & $\begin{array}{l}\text { Lavatórios em condições de higiene, dotados de sabonete } \\
\text { líquido inodoro anti-séptico ou sabonete líquido inodoro e anti- } \\
\text { séptico, toalhas de papel não reciclado ou outro sistema } \\
\text { higiênico e seguro de secagem e coletor de papel acionados } \\
\text { sem contato manual }\end{array}$ & & & \\
\hline LOCAL & CONFORMIDADES & $\mathbf{S}$ & $\mathbf{N}$ & OBSERVAÇÕES \\
\hline \multirow{8}{*}{ 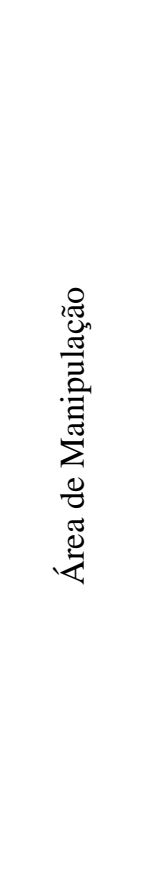 } & Higienização das mãos & & & \\
\hline & $\begin{array}{l}\text { Lixeiras com tampa acionada por pedal e em bom estado de } \\
\text { conservação }\end{array}$ & & & \\
\hline & Possui ventiladores & & & \\
\hline & $\begin{array}{l}\text { Sistema de ventilação/ exaustão/ climatização com proteção } \\
\text { contra acesso de sinantrópicos e vetores }\end{array}$ & & & \\
\hline & $\begin{array}{l}\text { Equipamentos em quantidade suficiente e em bom estado de } \\
\text { conservação }\end{array}$ & & & \\
\hline & Coifas providas de filtro e proteção & & & \\
\hline & $\begin{array}{l}\text { Não há presença de moveis/utensílios de madeira em área de } \\
\text { produção }\end{array}$ & & & \\
\hline & $\begin{array}{l}\text { Utensílios em quantidade suficiente e em bom estado de } \\
\text { conservação }\end{array}$ & & & \\
\hline
\end{tabular}




\begin{tabular}{|c|c|c|c|c|}
\hline & Área de uso exclusivo para higienização de utensílios & & & \\
\hline LOCAL & CONFORMIDADES & $\mathbf{s}$ & $\mathbf{N}$ & OBSERVAÇÕES \\
\hline \multirow{5}{*}{ 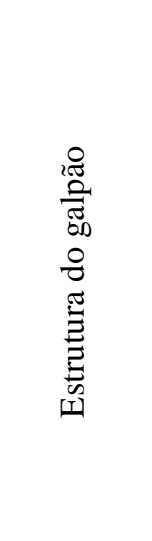 } & $\begin{array}{l}\text { Piso com material liso, impermeável, sem imperfeições e sem } \\
\text { acumulo de líquidos e resíduos }\end{array}$ & & & \\
\hline & $\begin{array}{l}\text { Paredes com acabamento liso, impermeável, de cor clara, livres } \\
\text { de rachaduras, bolores, descascamentos }\end{array}$ & & & \\
\hline & $\begin{array}{l}\text { Tetos/ forros com acabamento liso, impermeável, de cor clara, } \\
\text { livres de rachaduras, bolores, descascamentos e goteiras }\end{array}$ & & & \\
\hline & $\begin{array}{l}\text { Portas com acabamento liso, impermeável, ajustadas aos } \\
\text { batentes e com proteção contra entrada de sinantrópicos e } \\
\text { sujidades }\end{array}$ & & & \\
\hline & Não há exposição de fiação elétrica & & & \\
\hline LOCAL & CONFORMIDADES & $\mathbf{S}$ & $\mathbf{N}$ & OBSERVAÇÕES \\
\hline \multirow{2}{*}{ 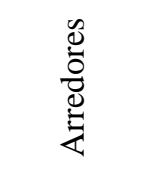 } & Presença de animais, insetos (descrever quais) & & & \\
\hline & Presença de resíduos (descrever quais) & & & \\
\hline LOCAL & CONFORMIDADES & $\mathbf{S}$ & $\mathbf{N}$ & OBSERVAÇÕES \\
\hline \multirow{4}{*}{ 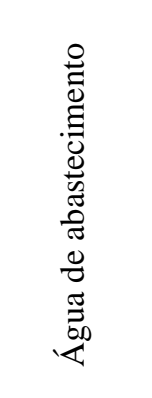 } & Captada de serviço público de saneamento & & & \\
\hline & $\begin{array}{l}\text { Realização de tratamento e monitoramento de qualidade da } \\
\text { água usada no estabelecimento }\end{array}$ & & & \\
\hline & Realização de testes laboratoriais & & & \\
\hline & Higienização dos reservatórios a cada 6 meses & & & \\
\hline
\end{tabular}




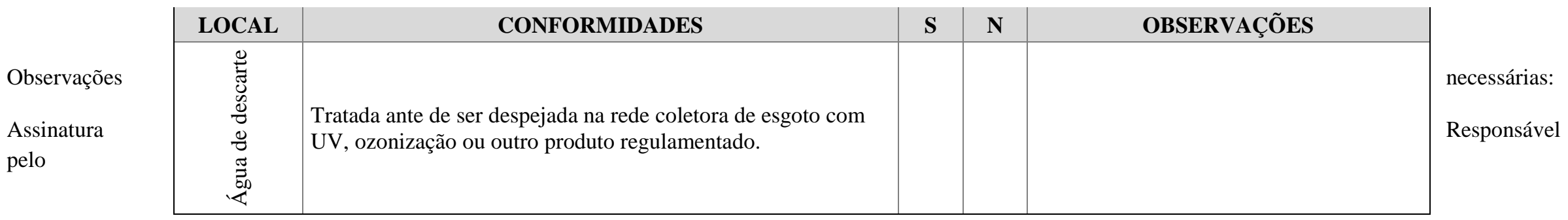

estabelecimento:

Data: 
Apêndice 3

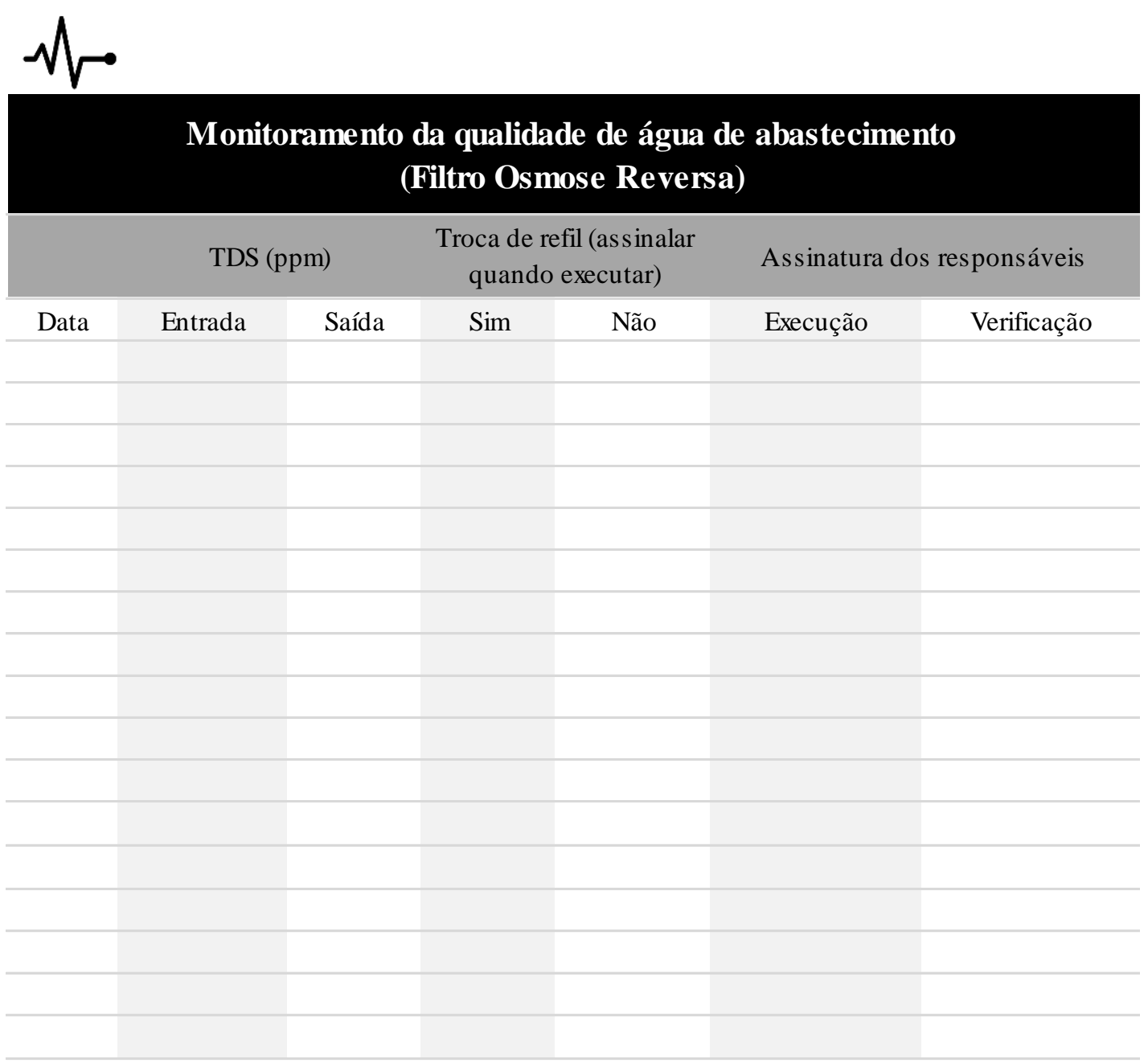

Elaborado por (nome do responsável por elaborar), em (data da elaboração). Aprovado por (nome do responsável por aprovar), em (data da aprovação). Implantado por (nome do responsável por implantar), em (data da implantação). Revisado por (nome do responsável por revisar), em (data da revisão). 
Apêndice 4

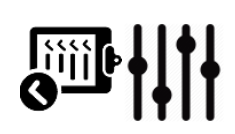

Planilha de Recebimento de peixes ornamentais

Data: __________

Fornecedor:

Responsável pelo monitoramento do recebimento :

Cargo:

\section{Tópicos a serem avaliados na inspeção(Avaliação)}

1 - Embalagem de transprote de fácil inspeção

2 - Embalagem de transporte turva ou comágua suja

3 - Animais saudáveis

4 - Animais visivelmente doentes ou que apresentam sinais de sofrimento

\section{Procedimento para aceitação, recusa e bloqueio de compra de animais}

A) Animais são aceitos e ficam na empresa [1,3]

R) Animais são recusados e não ficam na empresa [1,4] [2,4] [2,3]

B) Bloqueio de compra da espécie que apresentou problemas na avaliação após três recusas até a resolução do problema B

\begin{tabular}{llll} 
Discriminação & Avaliação & Procedimento & Observações (quando necessário) \\
\hline Espécie 1 & 1,3 & $\mathrm{~A}$ & \\
\hline Espécie 2 & 2,4 & $\mathrm{R}$ \\
\hline Espécie 3 & 2,4 & $\mathrm{~B}$ \\
\hline Espécie 4 & 2,4 & $\mathrm{R}$ \\
Espécie 5 & 2,3 & $\mathrm{R}$
\end{tabular}

Listar se for posssivel o que foi encontrado de errado:

Elaborado por (nome de quem elaborou), em (data da elaboração). Aprovado por (nome do responsável por aprovar), em (data da aprovação). Implantado por (nome do responsável por implantar), em (data da implantação). Revisado por (nome do responsável por revisar), em (data da revisão). 
Apêndice 5

Check List para saída de animais do estabelecimento
Data: ___
Cliente:
Responsável pela conferência:

$\mathrm{N}^{\mathrm{o}}$ do pedido de compra:

\section{Tópicos a serem analis ados antes do envio}

1- Animais saudáveis e apresentando um bom escore corporal para viagem;

2 - Volume da água de transporte, oxigênio e embalagem proporcional à quantidade de ani

3 - Embalagem corretamente etiquetada;

\begin{tabular}{|c|c|c|c|c|c|}
\hline & 1 & 2 & 3 & Apto & Decisão \\
\hline Espécie 01 & Sim & Sim & Sim & Sim & Envia \\
\hline Espécie 02 & Não & Sim & $\mathrm{Sm}$ & Não & $\begin{array}{l}\text { Corrige o erro para } \\
\text { ficar apto ao envio }\end{array}$ \\
\hline Espécie 03 & Sim & Não & Não & Não & $\begin{array}{l}\text { Corrige o erro para } \\
\text { ficar apto ao envio }\end{array}$ \\
\hline Espécie 04 & Sim & $\mathrm{Sim}$ & Sim & Sim & Envia \\
\hline Espécie 05 & Sim & Sim & Sim & Sim & Envia \\
\hline Espécie 06 & Sim & Sim & Sim & Sim & Envia \\
\hline
\end{tabular}

Outras observações: 
Apêndice 6

\begin{tabular}{l} 
Controle diário da higienização dos utensílios -- Semana (X), Mês (Y) \\
Assinatura do executor da atividade \\
Domingo Segunda Terça Quarta Quinta Sexta Sábado \\
\hline Redes de captura \\
\hline Binças para alimentação \\
\hline Canecas \\
\hline Baldes \\
\hline Outros \\
\hline Executado por: \\
\hline Conferido por:
\end{tabular}

Elaborado por (nome do responsável por elaborar), em (data da elaboração). Aprovado por (nome do responsável por aprovar), em (data da aprovação). Implantado por (nome do responsável por implantar), em (data da implantação). Revisado por (nome do responsável pela revisão), em (data da revisão).

Apêndice 7

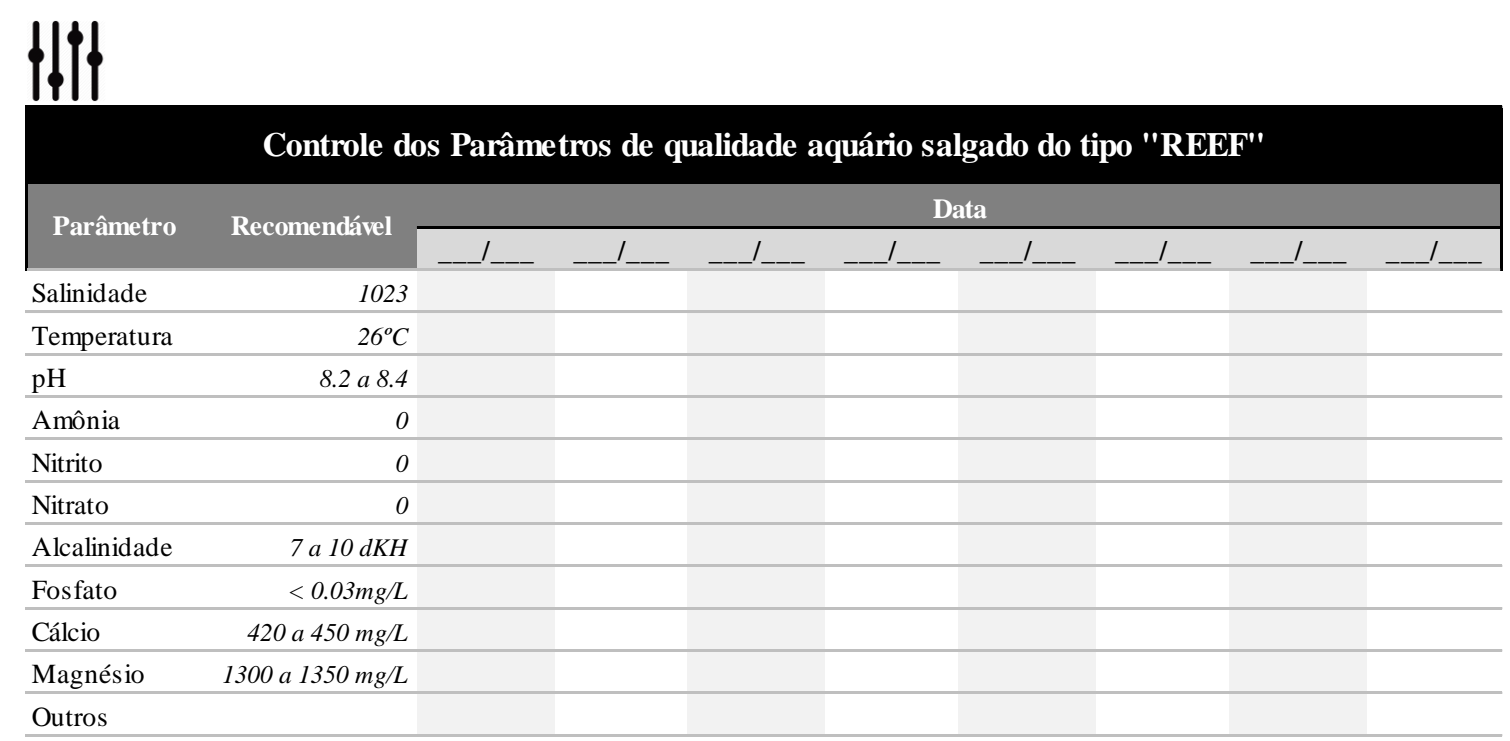

Elaborado por (nome do responsável por elaborar), em (data da elaboração). Aprovado por (nome do responsável por aprovar), em (data da aprovação). Implantado por (nome do responsável por implantar), em (data da implantação).

Revisado por (nome do responsável pela revisão), em (data da revisão). 


\section{Capítulo 3}

Principais perigos biológicos de natureza bacteriana, viral, fúngica e parasitária associados aos peixes ornamentais e medidas de prevenção e controle 


\subsection{INTRODUÇÃO}

O comércio de animais aquáticos vivos facilita a disseminação de inúmeros agentes patogênicos, muitos dos quais vinculados por movimentos antropogênicos através da translocação desses organismos, incluindo-se plantas entre outros; o que causa sérios problemas em regiões indenes (PEELER; FEIST, 2011).

A incidência de agentes patogênicos em peixes são, na grande maioria das vezes desencadeados pelo estresse ao qual são submetidos. Exemplos de estresse incluem alta densidade de animais em aquários, embalagens e sistemas aquáticos, excesso de ruído, agressão de uma espécie à outra em ambiente não compatível, má qualidade de água que inclui mudanças bruscas na temperatura e na composição química da água em um curto espaço de tempo, entre outros (ANNIE SELVA SONIA; LIPTON, 2012).

A disseminação de doenças pode ser agravada caso os estabelecimentos de aquicultura para fins comerciais não adotem medidas preventivas para impedir ou reduzir a ocorrência de certos patógenos (perigos), principalmente no período de quarentena (WHITTINGTON; CHONG, 2007; MEHRDANA et al., 2014).

A análise de perigos é o primeiro princípio básico e inicial no desenvolvimento do plano APPCC. Consiste na identificação de todos os perigos significativos de natureza bacteriana, viral, fúngica e parasitária, que possam ocorrer em cada uma das etapas pelas quais são submetidos os peixes ornamentais desde a sua obtenção, criação ou captura até a expedição pelo distribuidor e determinação das medidas preventivas e de controle. É essencial que esse processo seja conduzido a partir da literatura científica de forma detalhada, pois a aplicação dos outros seis princípios do sistema APPCC depende da criteriosa execução do primeiro princípio(ALMEIRA et al., 2005).

Os perigos podem comprometer a saúde e consequentemente qualidade dos peixes ornamentais, e ocasionar prejuízos econômicos para os comerciantes e para os consumidores. Devem ser objeto de análise todo e qualquer detalhe, prática, procedimento ou outro aspecto relacionado ao processo, desde a origem do produto até a sua distribuição. É necessário uma análise para cada estabelecimento de aquicultura e categoria de espécies comercializadas (BRASIL, 1998).

Dessa forma, este capítulo apresenta os principais perigos biológicos de natureza bacteriana, viral, fúngica e parasitária relacionados aos peixes ornamentais e as principais medidas 
preventivas para elimina-los ou reduzi-los a níveis aceitáveis, em um estabelecimento distribuidor atacadista.

\subsection{MATERIAL E MÉTODOS}

Para a identificação dos perigos biológicos relacionados aos peixes ornamentais e medidas preventivas para controle, foi feito levantamento com base no histórico de dados de identificação dos principais patógenos diagnosticado no estabelecimento utilizado como cenário e confirmado com o histórico bibliográfico encontrado no banco de dados Scopus (http://www.scopus.com), PubMed (http://www.ncbi.nlm.nih.gov), $\quad$ Scielo (http://www.scielo.org) e Google Acadêmico (https://scholar.google.com.br/) com as palavras-chave: "ornamental fish disease" e "doenças em peixes ornamentais", principalmente nos últimos 10 anos.

\subsection{RESULTADOS E DISCUSSÃO}

\subsubsection{Perigos biológicos}

\subsubsection{Perigos biológicos de natureza bacteriana}

As doenças de etiologia bacteriana são comuns em peixes ornamentais e mais frequentemente associadas às bactérias ubíquas do ambiente aquático. Os sinais clínicos, de forma genérica, incluem lesões ulcerativas e hemorrágicas na pele, opacidade de córnea, infecções sistêmicas e septicemia (ROBERTS; PALMEIRO; WEBER, 2009).

As doenças bacterianas em peixes envolvem uma ação combinada de diversos fatores incluindo ambiente, hospedeiro (função imunológica, susceptibilidade do hospedeiro, etc) e fatores específicos de cada patógeno tal como virulência (ROBERTS; PALMEIRO; WEBER, 2009). A grande maioria dessas bactérias faz parte da flora intestinal dos peixes ou da água, e convivem bem com os seres aquáticos caso haja equilíbrio no ecossistema. Porém quando há um aumento na concentração de matéria orgânica e inorgânica, essas bactérias se multiplicam e tem caráter oportunista e podem ser patogênicas aos peixes suscetíveis(LEWBART, 2001; AL-HARBI; UDDIN, 2004; RAJA et al., 2006). Para minimizar esses problemas, é necessário a adoção de medidas preventivas para o controle desses patógenos.

No período de janeiro a dezembro de 2016, 295 amostras de diferentes espécies de peixes ornamentais que apresentavam sinais clínicos de lesão de pele (figura 24a), ocular (figura 24b e 24c) e septicemia (figura 24d) foram enviadas pelo RT do estabelecimento utilizado como 
cenário para o Laboratório de Sanidade Suína da FMVZ/USP para diagnóstico de doenças de etiologia bacteriana.

Dos isolados obtidos (Apêndice 8 e 9), as espécies mais frequentes foram: Aeromonas hydrophilla, Aeromonas veroni, Aeromonas caviae, Aeromonas jandei, Citrobacter freundii, Klebsiella pneumoniae, Shevanella putrefasciens e Vibrio albensis. Embora em menor número também foram identificadas bactérias das espécies Aeromonas enteropelogenes, Aeromonas icthiosmia, Acinetobacter baylyi, Acinetobacter junii, Citrobacter braakii, Citrobacter gillenii, Edwardisella tarda, Enterobacter asburiae, Enterococcus hirae, Pseudomonas alcaligenes e Plesiomonas shigueloides.

Os resultados dos isolados de bactérias de peixes ornamentais doentes no estabelecimento utilizado como cenário corroboram com a literatura que cita os gêneros, Aeromonas (MARTÍNEZ-MURCIA et al., 2008; SREEDHARAN; PHILIP; SINGH, 2011; WONGLAPSUWAN et al., 2016), Citrobacter (ROBERTS; PALMEIRO; WEBER, 2009), Edwardsiella (HUMPHREY et al., 1986; LOWRY; SMITH, 2007; HAWKE et al., 2013), Plesiomonas (NISHA et al., 2014), Shewanella (PĘKALA et al., 2015), Vibrio (TENDENCIA, 2004; MARTINS et al., 2010; ABD EL-GALIL; MOHAMED, 2012; HASHEM; EL-BARBARY, 2013) comuns em peixes ornamentais.

As espécies mais comuns relatadas em peixes são Aeromonas hydrophilla, Aeromonas veroni, Aeromonas caviae (YUCEL; ASLIM; BEYATLI, 2005; CITARASU et al., 2011; GRIM et al., 2013), Citrobacter freundii (Gallani, Sebastio, Vallado, Boaratti, \& Pilarski, 2016), Shevanella putrefaciens (CHEN et al., 1997; ALTUN et al., 2014; BEAZ-HIDALGO et al., 2015), 
Figura 24: (a) Lesão de pele em Cyprinus carpio; (b),(c) lesão ocular em Carassius auratus; (d) sinais de septicemia em Carassius auratus
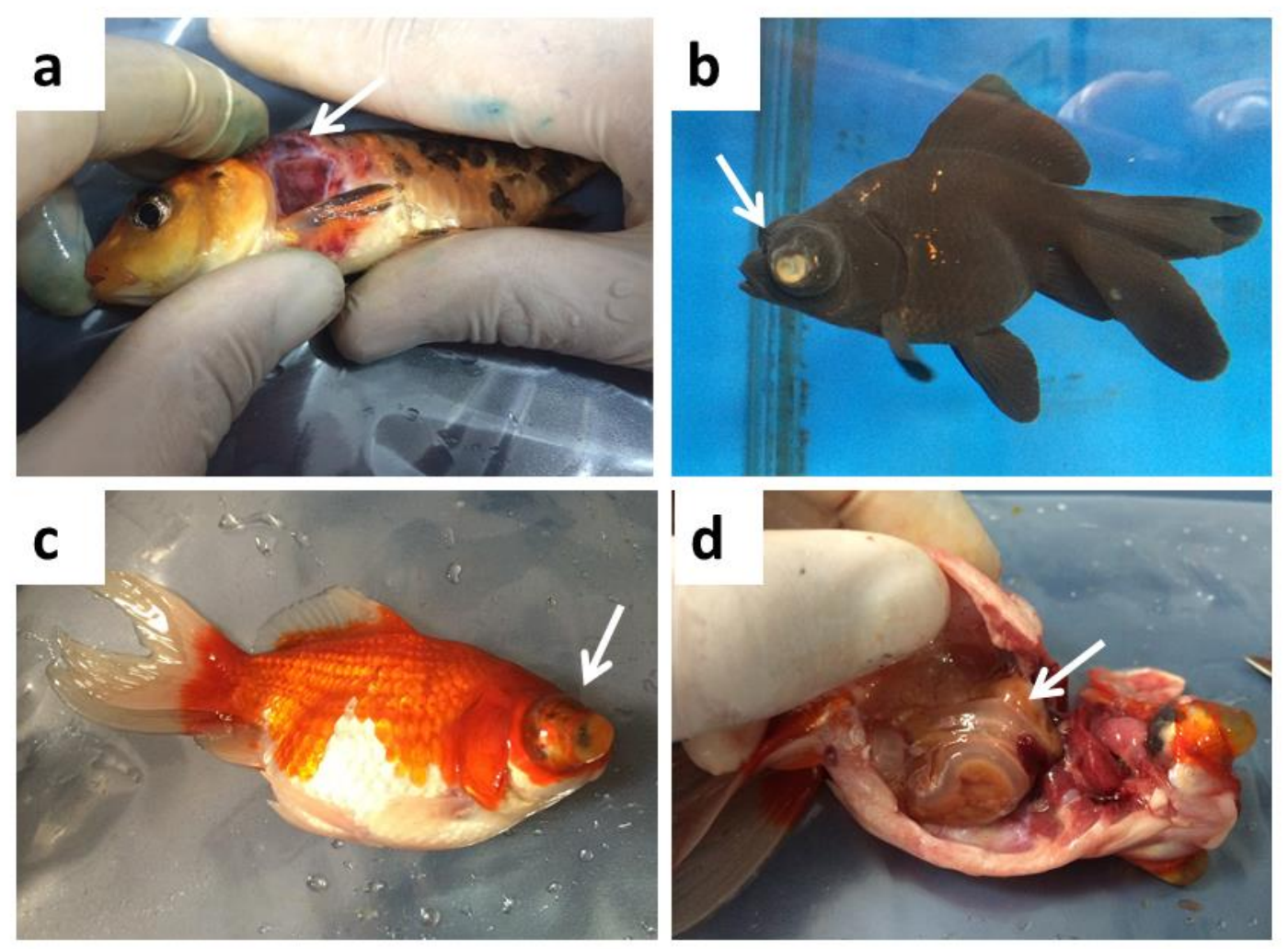

Fonte: Cardoso, 2017

Embora não isoladas, bactérias dos gêneros Francisella (COLQUHOUN; DUODU, 2011; CAMUS et al., 2013; LEWISCH; DRESSLER; SALEH, 2014), Flavobacterium (DECLERCQ et al., 2013, 2015; GUZ et al., 2014; VERMA et al., 2015), Mycobacterium (AUBRY et al., 2002; PREARO et al., 2004; ESSA; KENAWY; EL-GAWAD, 2009; CHEUNG et al., 2012; WHIPPS; LIEGGI; WAGNER, 2012; WU et al., 2012), Streptococcus (TUKMECHI et al., 2009) também estão associados a doenças em peixes ornamentais.

Infecção por Flavobacterium columnare, causador da doença "Columnariose" é relativamente comum em peixes ornamentais de aquários e facilmente identificada pelas características das lesões causadas, associadas à técnica de Gram do esfregaço da área lesionada. É uma bactéria de difícil crescimento em meios de cultura habituais (DECLERCQ et al., 2013). As lesões começam como áreas de descoloração pálida da pele, que geralmente são cercadas por uma zona de coloração avermelhada (figura 25a). É uma bactéria gram negativa em forma de bastonete (figura $25 \mathrm{~b}$ ). 
Figura 25: (a) Lesões arredondas com bordas avermelhadas em Polypterus senegalus; (b) bastonetes gram negativos do esfregaço das áreas lesionadas (aumento de 100X).

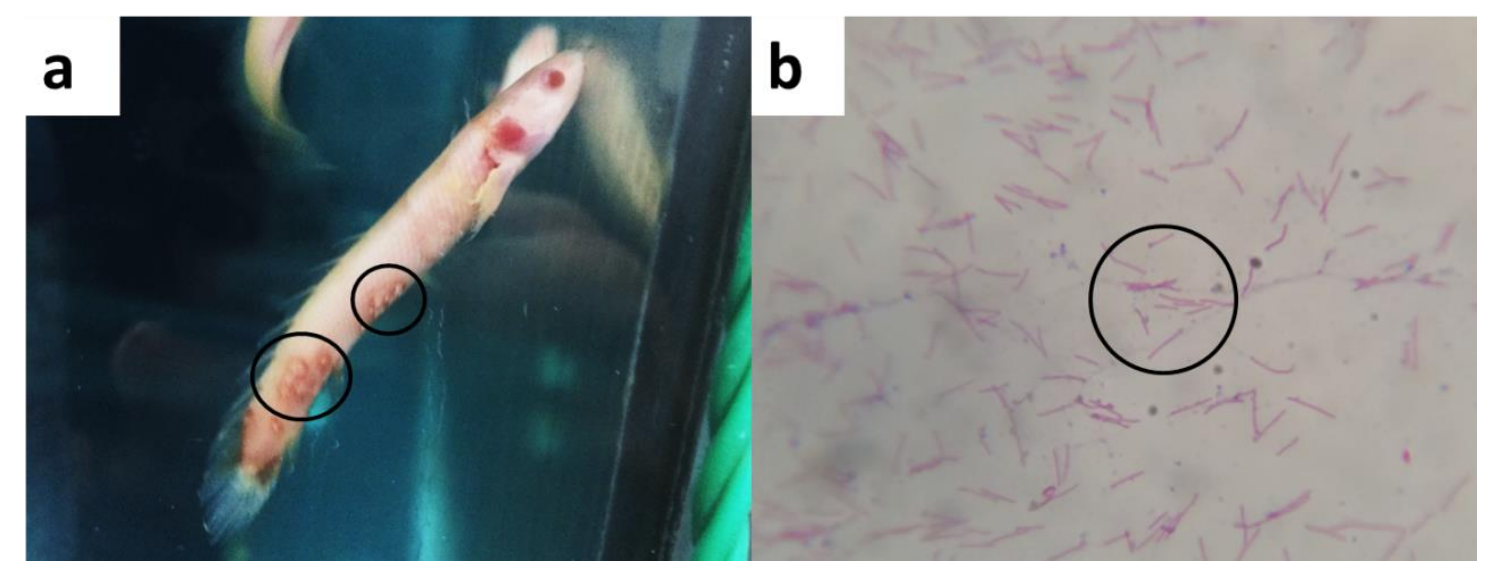

Fonte: Cardoso, 2017

\subsection{Perigos biológicos de natureza bacteriana zoonóticos}

Aeromonas hydrophilla, Aeromonas veroni, Shevanella putrefaciens, Edwardisella tarda, Pseudomonas alcaligenes entre outras além de causar doenças em peixes, também tem caráter zoonótico (HUMPHREY et al., 1986; LEHANE; RAWLIN, 2000; YUCEL; ASLIM; BEYATLI, 2005; SREEDHARAN; PHILIP; SINGH, 2011; SUZUKI et al., 2013) e são comuns ocorrerem em ambiente aquáticos.

Em países como Japão e China a micobacteriose é conhecida como uma importante doença ocupacional para pessoas que trabalham com aquários; causa lesões granulomatosas crônicas de difícil tratamento; em alguns casos é necessário remoção cirúrgica das lesões devido a ineficiência do tratamento com antibióticos; e em raros casos é necessário amputação dos membros lesionados. Apesar do gênero não ter sido isolado, a literatura cita as espécies Mycobacterium marinum, $M$. fortuitum e $M$. chelonae como sendo as mais comuns e que acomete o ser humano (PATE et al., 2005; ESSA; KENAWY; EL-GAWAD, 2009; CHEUNG et al., 2012; WHIPPS; LIEGGI; WAGNER, 2012) e as infecções em humanos estão quase sempre relacionadas à ausência de boas práticas no manejo dos animais (YANONG; POUDER, 2010).

A ocorrência dessas espécies mencionadas anteriormente coloca em risco a saúde dos profissionais que trabalham em estabelecimentos que comercializam peixes ornamentais. Essa característica exige rigor na manutenção das boas práticas de manuseio e manejo de toda a estrutura de manutenção e comercialização desses organismos.

\subsubsection{Medidas Preventivas para os perigos de natureza bacterina em peixes ornamentais}


As boas práticas de manejo e higiene são as chaves para prevenção de doenças bacterianas em peixes. É importante que o animal tenha procedência de locais que possuam controle sanitário (o que assegura a ausência de determinados agentes e patógenos), seja recebido sem sinais clínicos de doenças e seja mantido em um ambiente com excelente qualidade de água e baixos níveis de matéria orgânica com o intuito de diminuir o estresse que poderá ser gerado aos peixes(CROSBY et al., 2014).

Adicionalmente, é necessário que estabelecimentos cujos aquários funcionam sob sistema de recirculação de água, utilizem mecanismos para tratamento da água de recirculação, comprovadamente eficiente, tal como filtro de irradiação ultravioleta (figura 26a) e ozonização (figura 26b) para inativação das bactérias presentes na água (SHARRER; SUMMERFELT, 2007).

A irradiação ultravioleta é absorvida por proteínas e ácidos nucleicos, provocando o rompimento de cromossomo, mutações genéticas e inativação de enzimas e consequentemente a morte da célula (ALEXANDRE; FARIA; CARDOSO, 2008) dos diversos dos patógenos (bactérias, vírus, fungos e parasitas) de peixes.

O ozônio é um poderoso agente oxidante também amplamente utilizado na aquicultura. É utilizado tanto na desinfecção (pois oxida patógenos de peixes) como na melhoria da qualidade de água(oxida resíduos orgânicos, incluindo coloração, odor e nitrito) (SUMMERFELT, 2002).

Cada um dos métodos de tratamento de água (irradiação ultravioleta ou ozonização da água) podem ser usados separadamente em sistemas de recirculação(aquários), porém quando usados em conjunto tem o efeito potencializado no controle de patógenos de peixes (SHARRER; SUMMERFELT, 2007; SUMMERFELT et al., 2009). 
Figura 26: (a) Filtro de irradiação ultravioleta; e (b) aparelho gerador de ozônio, para tratamento de água de recirculação em aquários
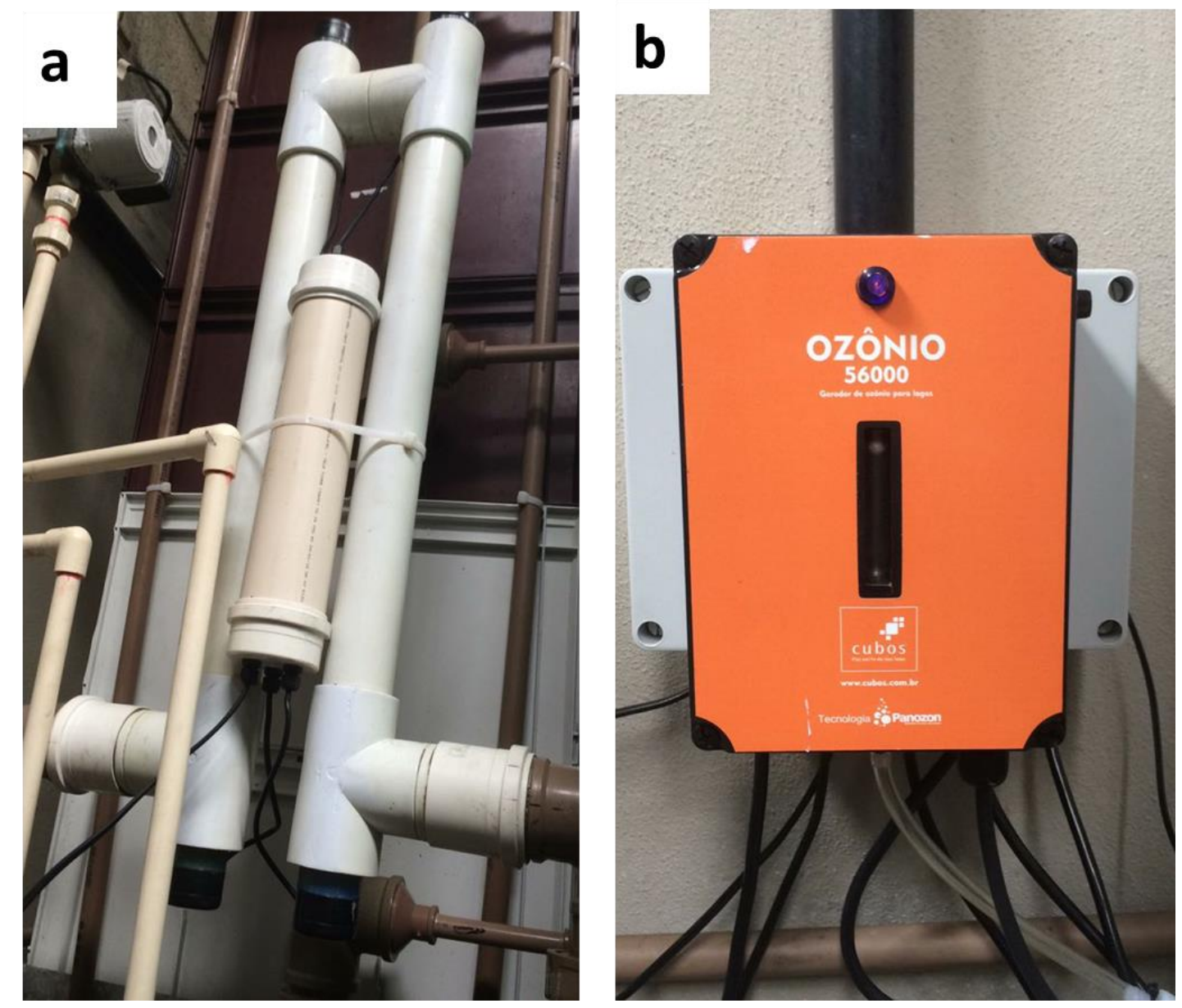

Fonte: Cardoso, 2017

A aplicação desses mecanismos é uma importante medida preventiva que reduz a carga bacteriana da água e consequentemente também reduz a ocorrência de doenças oportunistas de etiologia bacterina (SHARRER; SUMMERFELT, 2007; ROBERTS; PALMEIRO; WEBER, 2009; PARK et al., 2013).

A prevenção da disseminação de perigos biológicos de natureza bacteriana em estabelecimentos comerciais de peixes é também minimizado adotando-se a utilização exclusiva de utensílios individuais para cada sistema; impedindo a ocorrência de contaminações cruzadas entre um sistema aquático e outro (KENT et al., 2009b). Associada a esta prática, realizar a limpeza e desinfecção desses utensílios com produtos específicos para uso na aquicultura como a Cloramina-T, desinfetante amplamente utilizado na aquicultura mundial e regulamentado para venda no Brasil (GAIKOWSKI et al., 2004; OIE, 2012). 
É impossível manter os peixes em uma água estéril, pois há bactérias comensais da pele e flora intestinal sendo eliminadas constantemente na água. Porém tudo o que puder ser feito, para diminuir a taxa de multiplicação dessas bactérias na água, sem causar danos aos peixes será positivo.

\begin{tabular}{|c|c|c|}
\hline \multicolumn{3}{|c|}{ Resumo dos principais perigos e medidas preventivas } \\
\hline Perigo biológico & Principais Agentes & Medidas Preventivas \\
\hline Bacteriano & $\begin{array}{l}\text { Aeromonas spp., Citrobacter } \\
\text { spp., Edwardsiella sp., } \\
\text { Enterococus sp., Flavobacterium } \\
\text { sp., Francisella spp., Klebsiella } \\
\text { sp., Mycobacterium spp., } \\
\text { Pleisomonas sp., Pseudomonas } \\
\text { sp., Shevanella sp., Vibrio } \text { spp., } \\
\text { entre outras. }\end{array}$ & $\begin{array}{l}\text { 1) Adquirir animais de fornecedores que } \\
\text { adotem boas práticas de higiene e manejo; 2) } \\
\text { Inspeção visual a procura de lesões } \\
\text { características durante o recebimento; 3) } \\
\text { Manter os animais em sistema com excelente } \\
\text { qualidade de água durante o armazenamento } \\
\text { e utilização de métodos de tratamento da água } \\
\text { de recirculação com filtro de luz ultravioleta e } \\
\text { ozônio para reduzir a carga bacteriana na } \\
\text { água; 4) Adoção de boas práticas de higiene e } \\
\text { manejo em todas as etapas desde o } \\
\text { recebimento até a embalagem como já } \\
\text { discutido no Capítulo } 02 \text {. }\end{array}$ \\
\hline
\end{tabular}

\subsubsection{Perigos biológicos de natureza viral}

Mais de 125 vírus já foram identificados em peixes, e com o aumento das técnicas de identificação molecular, novas descobertas estão sendo feitas a cada dia (ESSBAUER; AHNE, 2001). As famílias Alloherpesviridae, Iridoviridae e Rhabdoviridae são importantes causas de doenças em peixes por provocarem altas taxas de morbidade e mortalidade (AHNE et al., 2002; WHITTINGTON; BECKER; DENNIS, 2010; GOTESMAN et al., 2013).

A família Alloherpesviridae (DNA vírus) possui quatro gêneros: Cyprinivirus, Batrachovirus, Salmonivirus e Ictalurivirus. O gênero mais associado a doenças em peixes ornamentais é o Cyprinivirus, o qual se caracteriza pela alta especificidade, provocando infecções persistentes com poucos ou sem sinais clínicos em animais adultos (HANSON; DISHON; KOTLER, 2011). As três espécies, Cyprinid herpesvirus 1, Cyprinid herpesvirus 2 e Cyprinid herpesvirus 3 pertecentes ao gênero Cyprinivirus estão associados a infecções em massa e altas taxas de mortalidade em carpas (Cyprinus carpio) e Kínguios (Carassius auratus) (DAVISON et al., 2013), embora outras espécies de peixes da família Cyprinidae também sejam susceptíveis.

A família Iridoviridae (DNA vírus) possui cinco gêneros: Iridovirus e Chloriridovirus, infectam invertebrados, Ranavirus, Megalocytivirus e Lymphocystivirus infectam vertebrados inferiores (WHITTINGTON; BECKER; DENNIS, 2010), sendo os dois últimos os mais frequentemente associados aos peixes ornamentais até o presente momento (YANONG; WALTZEK, 2010; YANONG, 2013). 
A família Rhabdoviridae (RNA vírus) possui o gênero Rhabdovirus carpio, que acomete ciprinídeos. É agente causador da viremia primaveral das carpas (AHNE et al., 2002), importante doença de notificação obrigatória (OIE, 2014b; BRASIL, 2015b).

No período de maio de 2015 à março de 2016 cinquenta e cinco (55) amostras de diferentes espécies de peixes ornamentais que apresentaram sinais clínicos de nado em círculos, letargia, distensão abdominal, hemorragias generalizadas e outras lesões suspeitas de doenças virais foram enviadas pelo RT do estabelecimento para o Laboratório de Higiene Zootécnia da FZEA-USP para diagnóstico molecular de infecções causadas por Cyprinid herspesvirus 1, Cyprinid herpesvirus 2, Cyprinid herpesvirus 3, Megalocytivirus e Lymphocystivirus pela técnica molecular de PCR. Paralelamente, durante todo o ano de 2016 amostras de peixes ornamentais com lesões nodulares suspeitos de Lymphocystivirus também foram examinados microscopicamente pelo médico veterinário RT para caracterização das lesões.

Das 55 amostras enviadas para diagnóstico molecular houve positividade em 36 (65\%) para Megalocytivirus e 1 (2\%) para Lymphocystivirus (Apêndice 10). Já para as vinte e oito (28) amostras analisadas microscopicamente para Lymphocystivirus, todas (100\%) tiveram lesões microscópicas características da lesão causada pela infecção viral (Apêndice 11).

É comum que pessoas que trabalhem com o setor de aquarismo se depare com mortes de peixes aparentemente sem causa definida, porém certamente o que acontece na maioria das vezes é a falta de conhecimento técnico suficiente para determinar a causa mortis ou ausência de diagnóstico clínico e laboratorial preciso de animais doentes. Geralmente o primeiro sinal de morbidade em doenças infecciosas em peixes é a anorexia. Logo, a esquipe responsável pela alimentação deve ser treinada para rapidamente identificar peixes com esse tipo de comportamento para que seja tomada uma ação pelo RT como já citado no ítem 2.3.6.3 do Capítulo 02 da presente tese.

As 36 amostras positivas (65\%) para Megalocytivirus eram de animais que não tiveram diagnóstico clínico concluído e a suspeita inicial era que os animais pudessem ter morrido devido a não adaptação ao novo ambiente. Não é possível determinar se os peixes já vieram dos fornecedores infectados pelo vírus ou se infectaram no estabelecimento. Outros estudos científicos também identificaram o vírus nos estabelecimentos mas não foi possível inferir a sua origem (WEBER et al., 2009; SRIWANAYOS et al., 2013; CARDOSO et al., 2017a). É necessário um controle em cadeia contínua que vai desde os produtores primários até as lojas, para que não haja lacunas no conhecimento, tornando o controle sanitário verdadeiro e integral para o setor de peixes ornamentais. 
Os peixes podem apresentar sinais clínicos inespecíficos que incluem letargia, comportamentos de nado irregular (figura 27a), anorexia, hiperpigmentação (figura 27b), exoftalmia, lesões na pele, anemia severa e fezes brancas. No exame post mortem os peixes infectados apresentam lesões hemorrágicas (figura 27c e 27d), esplenomegalia, nefromegalia, hepatomegalia e distensão de fluidos hemorrágicos (SRIWANAYOS et al., 2013). Apesar de causar $100 \%$ de mortalidade em determinadas espécies, diversos estudos já demonstraram que peixes clinicamente saudáveis podem albergar Megalocitivirus sem apresentar sinais, servindo então como reservatório(YANONG; WALTZEK, 2010) e infectar outros peixes susceptíveis que nunca tiveram contato com o vírus.

Figura 27: (a) Piranhas vermelhas (Pygocentrus nattereri) letárgicas nadando em círculo; (b) foram submetidas a necropsia; (c) hiperemia dos vasos intestinais com sinais de hemorragia (microscopia 4x); (d) brânquias com hemorragias localizadas (microscopia $4 \mathrm{x}$ ).
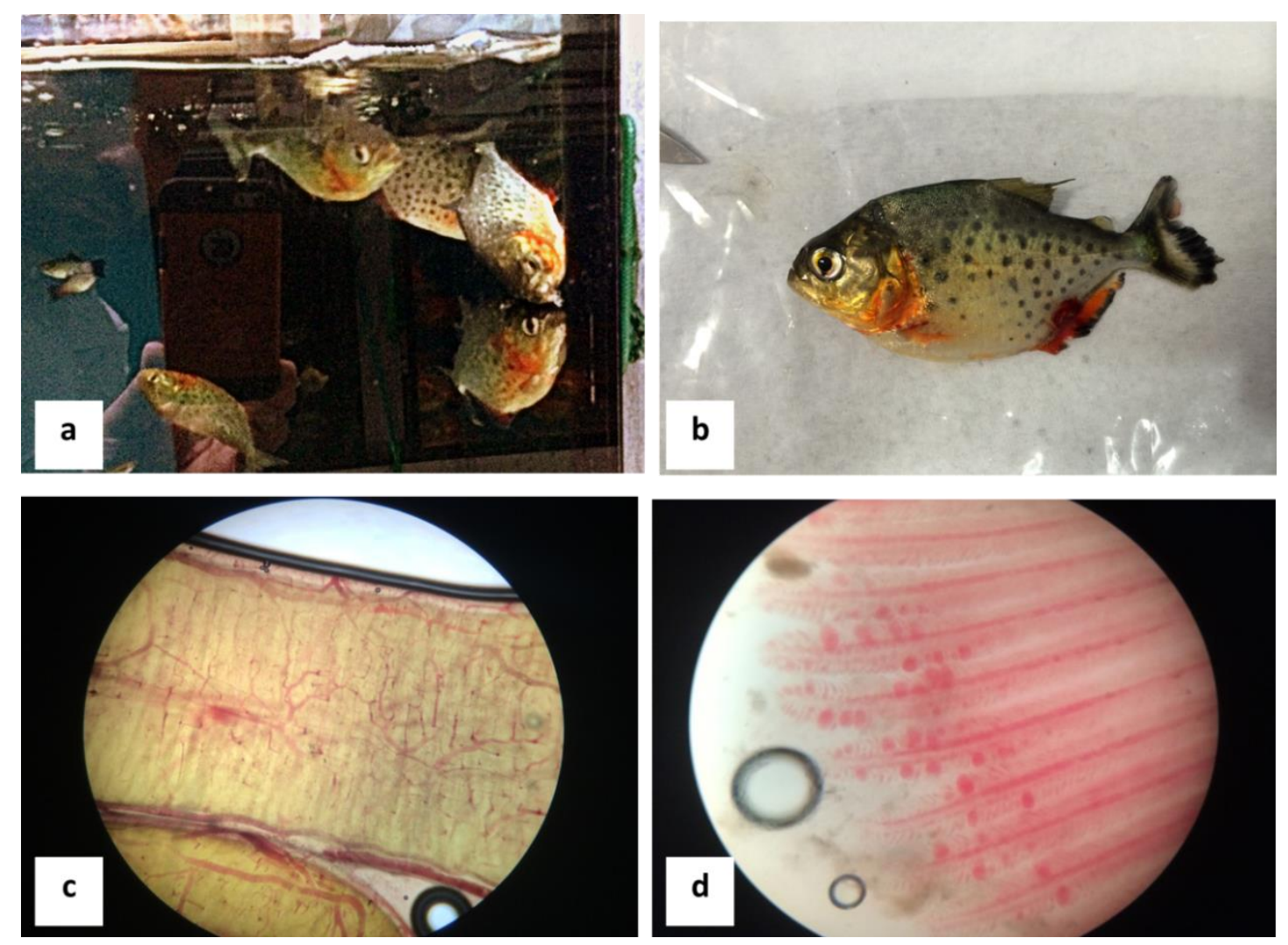

Fonte: Cardoso, 2017

Não houve positividade para Cyprinid herspesvirus 1, Cyprinid herpesvirus 2 e Cyprinid herpesvirus 3 nas amostras enviadas. Esse resultado não garante que não haja a circulação do vírus entre peixes ornamentais no Brasil. É importante a pesquisa e confirmação constante de agentes patogênicos de importância na indústria dos organismos aquáticos ornamentais. 
Somente com um banco de dados sobre a prevalência de doenças é possível estabelecer políticas de segurança sanitária eficiente e eficaz no país.

Vale salientar que desde 2007, a Koi Herpesvírus causada por Cyprinid herspesvirus 3 entrou para a lista de doenças de notificação obrigatória da OIE (GOTESMAN et al., 2013). Segundo a literatura científica, as principais espécies de peixes acometidas por Cyprinid herspesvirus 3 são carpas comuns (Cyprinus carpio) e carpas koi (Carassius auratus) pertencentes à família Cyprinidae.

Todas as amostras enviadas para diagnóstico molecular também foram testadas para Lymphocystisvírus, porém apenas uma amostra que já havia sido diagnosticada clinicamente com a lesão foi confirmada como positiva.

Peixes infectados por Lymphocystivirus apresentam lesões granulomatosas na pele e nadadeiras (figura 28a), facilmente visíveis na microscopia devido o acúmulo de fibroblastos na célula (figura 28b), sendo o diagnóstico relativamente fácil. Apesar de ser um vírus da família Iridoviridae, dentre os cinco gêneros este é o menos patogênico e dificilmente causa a morte do peixe (CARDOSO; BALIAN, 2016). O único problema é o aspecto repugnante do animal acometido, que não poderá ser comercializado até que as lesões desapareçam. É necessário a remoção das lesões, conforme elas apareçam, acelerando a recuperação do animal e reduzindo prejuízos para o estabelecimento comercial.

Figura 28: (a) Lesão nodular esbranquiçada na nadadeira caudal de Chaetodon auriga; (b) Lâmina a fresco, vista microscópica (10x) de nódulos fibroblásticos na nadadeira caudal de Chaetodon auriga.

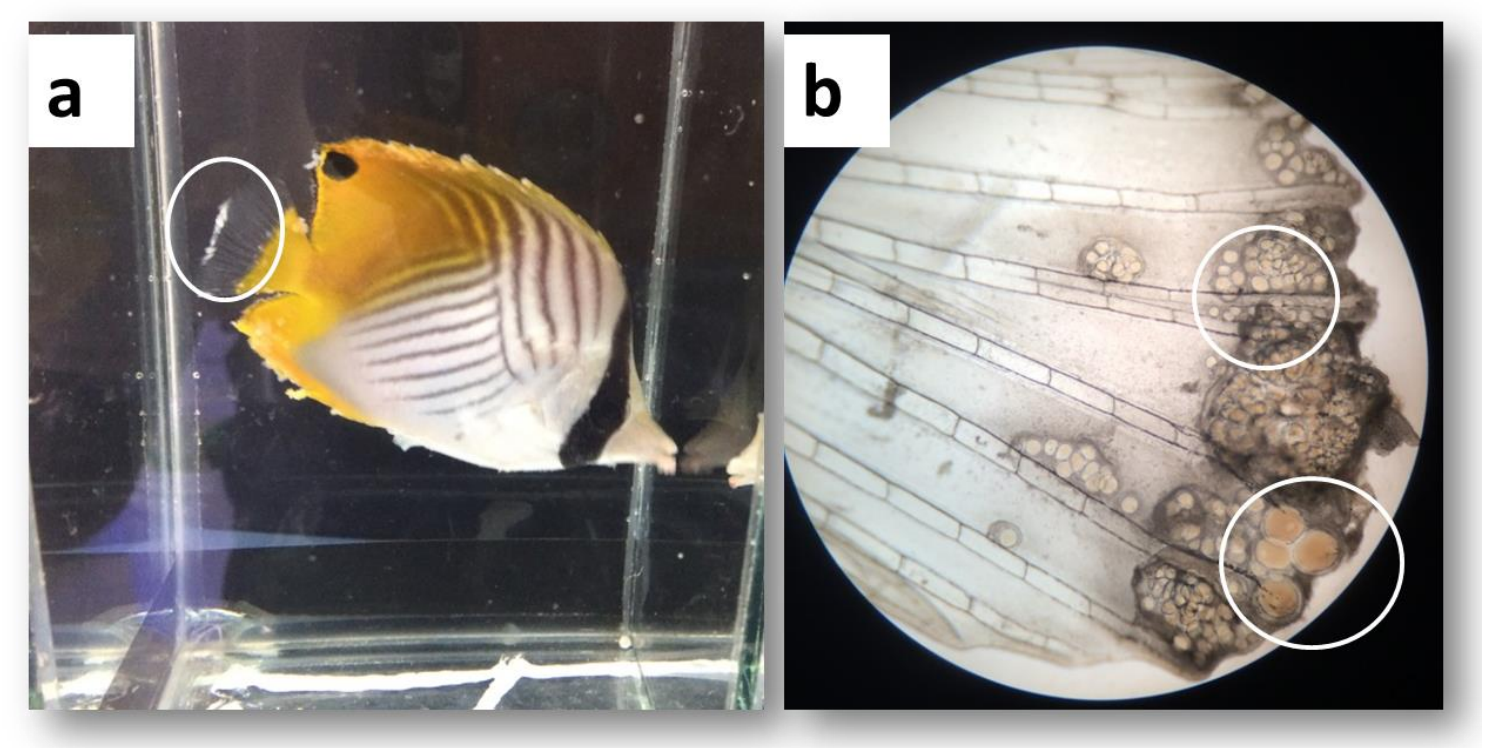

Fonte: Cardoso, 2017 
Apesar de não ter havido pesquisa para o Rhabdovirus carpio vale lembrar que esse é um importante agente causador da viremia primaveral das carpas, podendo acometer uma ampla variedade de espécies (SANDERS; BATTS; WINTON, 2003). Trata-se de uma doença de notificação obrigatória, segundo a OIE(OIE, 2014b; BRASIL, 2015b), e provoca altas taxas de mortalidade e prejuízos econômicos. Está amplamente disseminada por toda a Europa e há possibilidade que já ocorra no Brasil devido à importação de carpas húngaras no passado sem rigoroso controle sanitário e diagnóstico (ALEXANDRINO; RANZANI-PAIVA; ROMANO, 1998).

\subsection{Medidas Preventivas para os perigos de natureza viral em peixes ornamentais}

Os estabelecimentos que comercializam animais aquáticos devem adotar boas práticas relacionadas a biosseguridade, que incluem a desinfecção de tanques após a saída dos últimos animais, antes que novos adentrem; a desinfecção de utensílios utilizados na manipulação que deve ser individual e exclusiva para cada sistema (SMAIL et al., 2004) e o tratamento da água de recirculação com filtro de luz ultravioleta e ozônio (OATA, 2006), além de treinamento de colaboradores para identificação precoce de doenças com já mencionado no Capítulo 02.

A principal medida preventiva para doenças de natureza viral de interesse em peixes é a aquisição de animais de produtores que comprovem situação livre de doenças de interesse para o setor (HARTMAN et al., 2008; YANONG; WALTZEK, 2010; GOTESMAN et al., 2013; BECKER et al., 2014). É uma prática, ainda, difícil de se imaginar no Brasil seja pela cultura dos atores envolvidos na cadeia de peixes ornamentais ou de produção, seja pela ausência de laboratórios que façam exames diagnóstico viral ou até mesmo ausência de conhecimento técnico das principais doenças virais que acometem os peixes. É provável que pelo fato do Brasil ser "livre de doenças de notificação obrigatória" perante a OIE, não haja exigência legal da comprovação sanitária do plantel comercializado.

Aliado ao certificado de livre de doenças é essencial o estabelecimento adotar a prática de quarentena entre 15 e 90 dias para animais ingressantes, dependendo do patógeno de interesse e da finalidade dos animais. O ideal seria se essa prática fosse acompanhada por exames de sangue frequentes com o intuito de detectar animais que podem ser carreadores da doença (MCDERMOTT; PALMEIRO, 2013).

Não há exigência legal de quarentena para peixes criados em território nacional, partindo-se da premissa que, teoricamente, o Brasil é "livre" de doenças de interesse econômico e não há a presença de doenças de notificação obrigatória. Porém é necessário que haja monitoramento 
do plantel nacional em todas as esferas da comercialização para o conhecimento da real situação sanitária dos indivíduos comercializados.

\begin{tabular}{|c|c|c|}
\hline \multicolumn{3}{|c|}{ Resumo dos principais perigos e medidas preventivas } \\
\hline Perigo biológico & Principais Agentes & Medidas Preventivas \\
\hline Viral & $\begin{array}{l}\text { Cyprinid herpesvirus 1, Cyprinid } \\
\text { herpesvirus 2, Cyprinid } \\
\text { herpesvirus 3, Megalocytivirus, } \\
\text { Lymphocystivirus, Ranavirus, } \\
\text { Rhabdovirus carpio }\end{array}$ & $\begin{array}{l}\text { 1) Adquirir animais de fornecedores livres } \\
\text { da doença e que adote boas práticas de } \\
\text { higiene e manejo na criação; 2) Inspeção } \\
\text { visual a procura de lesões características } \\
\text { durante o recebimento; 3) Manter os } \\
\text { animais em sistema com excelente } \\
\text { qualidade de água durante o } \\
\text { armazenamento e utilização de métodos } \\
\text { de tratamento da água de recirculação com } \\
\text { filtro de luz ultravioleta e ozônio para } \\
\text { reduzir a carga viral na água; 4) Adoção de } \\
\text { boas práticas de higiene e manejo em todas } \\
\text { as etapas desde o recebimento até a } \\
\text { distribuição. 5) Período de quarentena } \\
\text { longo; 6) Treinamento de pessoas para } \\
\text { identificação precoce das doenças; 7) } \\
\text { Adoção de boas práticas de higiene e } \\
\text { manjo pelo estabelecimento desde o } \\
\text { recebimento até a expedição, como já } \\
\text { discutidos no Capítulo } 02 \text {. }\end{array}$ \\
\hline
\end{tabular}

\subsubsection{Perigos biológicos de natureza fúngicas}

Os Oomycetos (fungos aquáticos) da ordem Saprolegniales, tal como Aphanomyces e Saprolegnia, tem distribuição mundial e são responsáveis por infestações devastadoras em anfíbios, crustáceos e peixes de ambiente aquáticos de água doce (JIANG et al., 2013).

Aphanomyces invadans causa a síndrome epizoótica ulcerativa, e é uma das dez doenças de notificação obrigatória em peixes segundo a OIE, (OIE, 2014b).

Saprolegnia causa a Saprolegniose, doença fúngica mais comum em peixes ornamentais de aquário. É caracterizada por tufos brancos ou acinzentados no corpo ou nadadeiras de peixes de água doce, semelhantes a tufos de algodão, formado pelo micélio filamentoso. Nas extremidades das hifas formam-se os zoosporângios, em geral alongados, que contém os zoósporos. O fungo que é saprófita e cresce na presença de matéria orgânica tem caráter oportunista, e quando há infecção no peixe é quase certo que algo não vai muito bem no sistema aquático(VAN WEST, 2006).

No período de janeiro de 2015 a dezembro de 2016, um total de 45 (quarenta e cinco) amostras de peixes ornamentais de água doce que apresentaram lesões algodonosas (figura 29a) na superfície da pele e nadadeiras condizente com sinais clínicos causados por fungos 
foram analisados microscopicamente pelo médico veterinário RT do estabelecimento para a pesquisa de estruturas morfológicas características de fungos (Apêndice 12).

Das amostras analisadas, $100 \%$ possuíam características morfológicas condizentes com o gênero Saprolegnia. Na microscopia, corados com azul de algodão sob lâmina e lamínula é possível ver hifas, esporângios e zoósporos (figura 29b). Todos os animais que apresentaram as lesões fúngicas haviam sido recentemente submetidos a um longo período de viagem. O longo período de viagem gera estresse, e como consequência os peixes ficam mais susceptíveis à doenças. Aliado a esse fato, pode ser que o sistema aquático da empresa possuísse uma alta concentração de matéria orgânica, substrato para o crescimento fúngico.

Figura 29: (a) Lesão algodonosa na superfície dorsal de Baryancistrus sp; (b) Lâmina corada com azul de algodão, vista microscópica (10x), presença de hifas, esporângios e zoospóros.

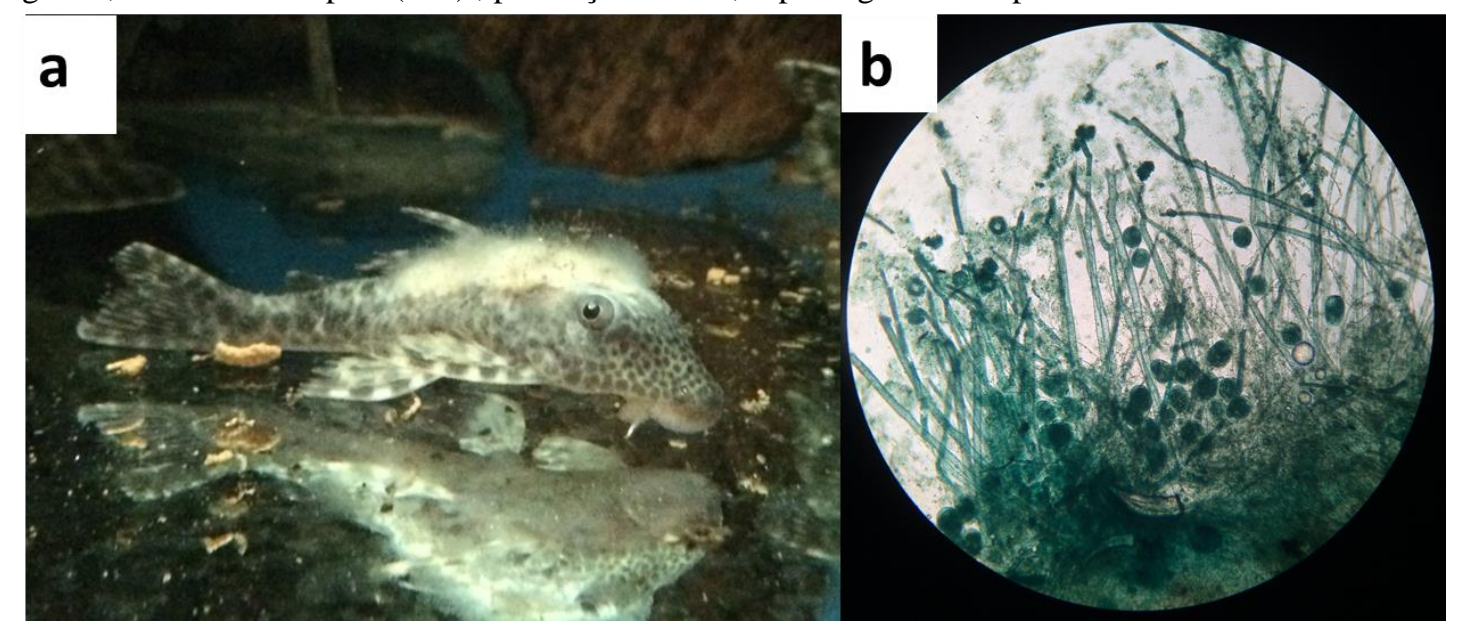

Fonte: Cardoso, 2017

Embora sejam raros os relatos, os gêneros Aspergillus, Penicillium, Alternaria, Blastomyces spp e Rhizopus também já foram isolados causando infecção em peixes ornamentais. Tais fungos tem caráter oportunista e também estão associados a altas concentrações de matérias orgânica na água (ZAFAR; SHEIKH; MUGHAL, 2012).

\subsection{Medidas Preventivas para os perigos de natureza fúngica em peixes ornamentais}

A prevenção de fungos na água é baseado principalmente no controle da qualidade de água para que não haja acúmulo de matéria orgânica e condições de estresse para os peixes, que proporciona o crescimento do fungo e diminui o sistema imunológico do animal respectivamente(OATA, 2006).

O tratamento da água através da ozonização e filtro de luz ultravioleta também são medidas preventivas eficientes. A ozonização reduz drasticamente a mortalidade de ovos causada por 
fungos, uma das principais enfermidades no setor produtivo de alevinos(POWELL et al., 2015). O ozônio além de quebrar a matéria orgânica presente no ambiente aquático, também reduz a quantidade de zoósporos ativos na água, que poderia ser fonte de infecção para novos hospedeiros.

\begin{tabular}{cc|l}
\hline \multicolumn{3}{c}{ Resumo dos principais perigos e medidas preventivas } \\
Perigo biológico & Principais Agentes & \multicolumn{1}{c}{ Medidas Preventivas } \\
\hline \multirow{3}{*}{ Fúngico } & $\begin{array}{c}\text { Alternaria, Aphanomyces, } \\
\text { Aspergillus, Blastomyces, } \\
\text { Penicillium, Rhizopus, }\end{array}$ & $\begin{array}{l}\text { 1) Controle de qualidade de água; 2) Evitar } \\
\text { situações de estresse nos peixes } \\
\text { ornamentais; 3) Tratamento da água com } \\
\text { luz ultravioleta e ozonização. }\end{array}$ \\
\hline
\end{tabular}

\subsubsection{Perigos biológicos de natureza parasitária}

Os perigos biológicos de natureza parasitária são frequentemente introduzidos no sistema através de animais sem sinais clínicos, que carreiam o agente e não passaram por um período de quarentena eficiente ou tratamento prévio apropriado. Outras práticas frequentes e responsáveis por introduzir parasitos no sistema é a adição de plantas sem uma prévia desinfecção, fômites contaminadas (equipamentos e utensílios), pássaros, rãs e os aerossóis entre aquários. Mais uma vez salienta-se a relevância das boas práticas de biosseguridade, de quarentena e do tratamento de animais infectados antes da introdução no sistema principal como estratégicas medidas preventivas (PIAZZA et al., 2006; ROBERTS-THOMSON et al., 2006; IQBAL; HAROON, 2014; MEHRDANA et al., 2014).

No período de janeiro de 2015 a dezembro de 2016, um total de 243 (duzentas e quarenta e três) amostras de peixes ornamentais de água doce e 81 (oitenta e uma) de água salgada que apresentaram comportamento anormal de incômodo e/ou sinais clínicos condizentes com lesões parasitárias foram analisados microscopicamente pelo médico veterinário RT do estabelecimento para a procura de ecto e endoparasitas. Cem por cento deles evidenciaram a presença de parasitas (Apêndice 13 e apêndice 14).

A porcentagem de cada parasita nos peixes de água doce do mais frequente para os menos frequentes foram: $31 \%$ Ichthyophthirius multifilis, $16,5 \%$ Ichthyobodo sp, 16,5\% Metacercária (sugestivo de Centrocestrus spp), 15,5\% Monogênea, 10\% Epistylis sp, 6\% Nematóide, 4,5\% Chillodonella sp, 4\% Lerneae sp, 3,5\% Spironucleus/ Hexamita, 2,5\% Tetrahymena sp, 2\% Piscinoodinium sp, $2 \%$ Trichodina sp 1\% Argulus sp.

Dentre os parasitas de água doce presentes no estabelecimento o Ichthyophthirius multifilis foi o de maior prevalência. Causa doença dos pontos brancos (figura 30a) que quando analisados na microscopia apresentam núcleo em forma de ferradura (figura 30b). É a espécie de parasita 
que mais causa problema para aquaristas em todo mundo. A doença é facilmente identificada através dos sinais clínicos e microscopia do raspado da área afetada. A disseminação é bastante rápida. Um único parasita dá origem a centenas de outros já prontos para infectar novos hospedeiros. Aquários superpopulosos são aqueles primeiramente acometidos, podendo levar a altas taxas de mortalidade. Quando diagnosticado precocemente e feito o tratamento, a recuperação é bem sucedida com perdas reduzidas (FRANCIS-FLOYD; REED, 2009).

Figura 30: (a) Doença dos pontos brancos causada por Ichthyophthirius multifilis no peixe ornamental Amphilophus trimaculatus; (b) Microscopia 20x. Parasita maduro com núcleo em forma de ferradura.
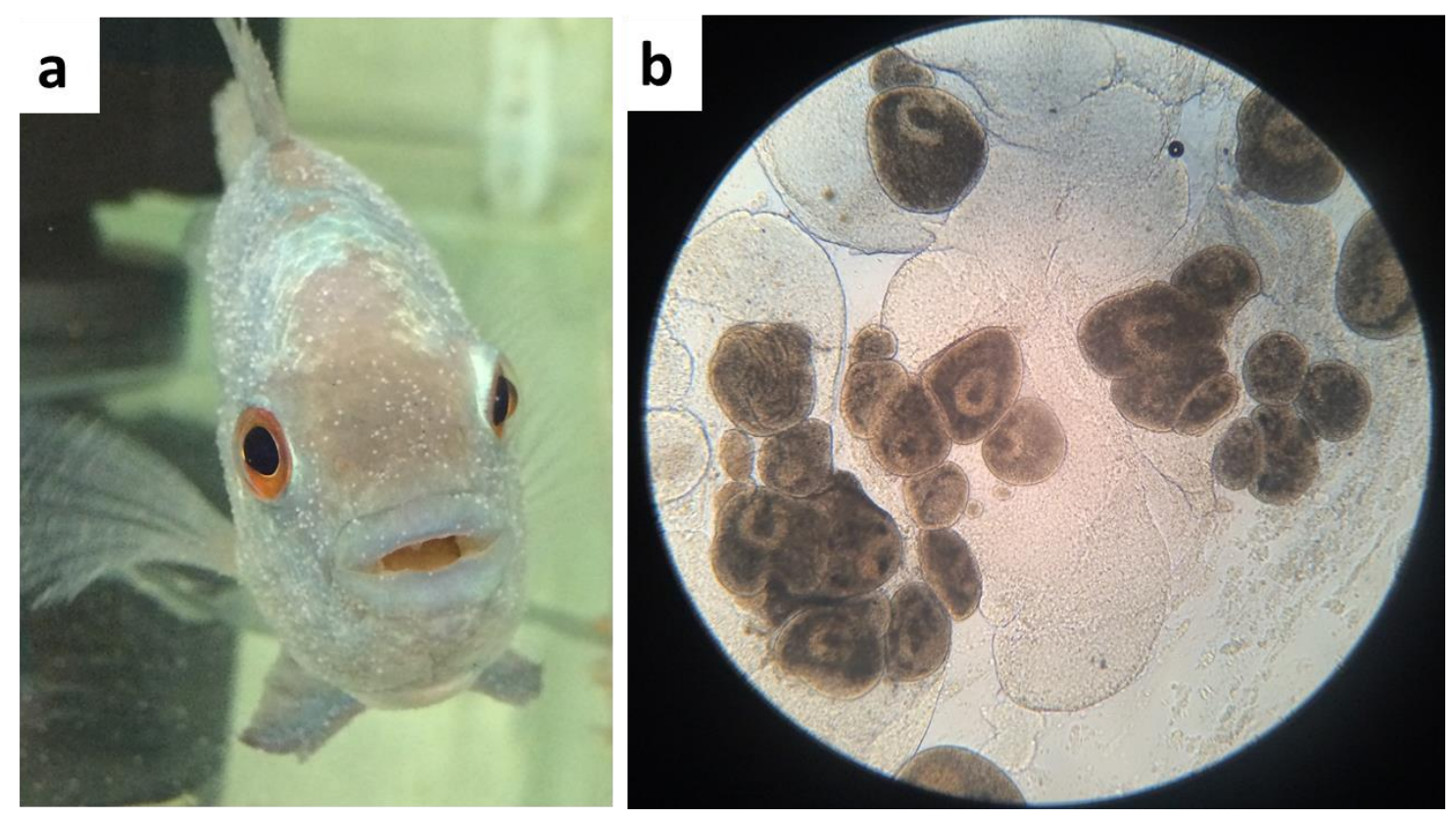

Fonte: Cardoso, 2017

Outros protozoários ectoparasitas prevalentes no plantel estudado, como Ichthyobodo sp, Epistylis sp, Chillodonella sp, Tetrahymena sp, Piscinoodinium sp, Trichodina sp são frequentemente relatados na literatura mundial (THILAKARATNE; RAJAPAKSHA; HEWAKOPARA, 2003; TAVARES-DIAS; LEMOS; MARTINS, 2010; IQBAL; HAROON, 2014; ADEL et al., 2015; SAHA; BANDYOPADHYAY, 2016). Quase sempre estão associados a ambientes aquáticos com baixa qualidade de água, alta concentração de matéria orgânica e manejo higiênico sanitário ineficiente. Esses parasitos infestam hospedeiros debilitados, provocando intenso estresse, lesões graves, levando os animais à morte, com significativas perdas econômicas (MARTINS et al., 2015).

Muitos peixes analisados (figura 31a) apresentavam metacercárias nas brânquias, (figura 31b) sugestivos do parasita Centrocestus sp. O ciclo de vida desse parasita requer um caramujo como hospedeiro de transporte. Boas práticas de manejo que impedem a entrada do molusco no sistema é suficiente para controlar a parasitose. Peixes com altas infestações por 
metacercárias encapsuladas nas brânquias apresentam deficiência respiratória e comportamento ofegante (MEHRDANA et al., 2014). Dentre os peixes que apresentavam metacercárias, $38 \%$ eram da espécie Xiphophorus maculatus provenientes de um produtor que relatou a presença de caramujos e outros animais como aves, insetos, anfíbios e mamíferos na propriedade, evidenciando nenhum controle sanitário com relação a este agente.

Figura 31: (a) Xiphophorus maculatus que se apresentava bastante debilitado e ofegante; (b) Microscopia aumento de 4x. Presença de metacercárias sugestivas de Centrocestus sp nas brânquias .
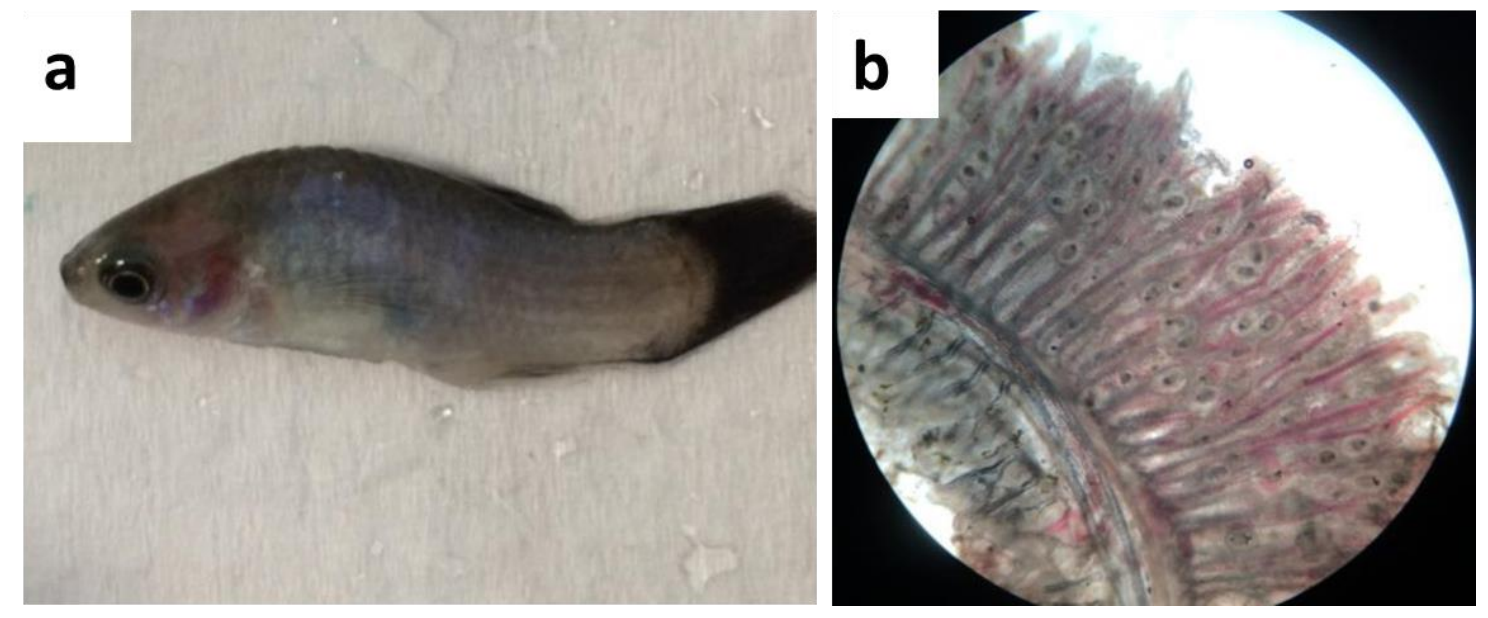

Fonte: Cardoso, 2017

Parasitas da classe das monogênas também se destacam em importância, acometendo peixes de água doce. Os gêneros mais ocorrentes são Dactylogyrus e Gyrodactylus. Tais parasitas possuem ganchos (figura 32b) que se fixam nos tecidos da pele (figura 32a) e brânquias do hospedeiro, provocando lesões que abrem oportunidades para infeções secundárias bacterianas (REED; FRANCIS-FLOYD; KLINGER, 2012; CARDOSO et al., 2017c).

Figura 32: (a) Polypterus palmas com monogêneas na pele e região ocular; (b) parasita no aumento microscópico de 4x, sugestivo de Gyrodactylus spp.
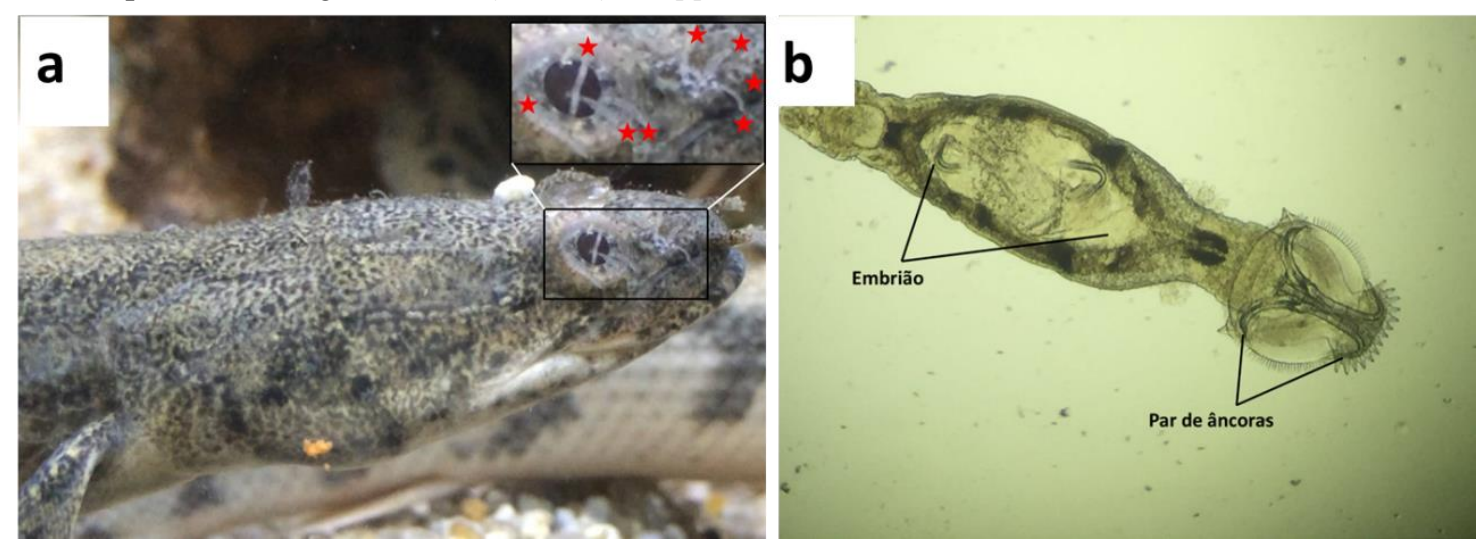

Fonte: Cardoso, 2017

Outros parasitas encontrados em menor frequência, foram Nematóides, Lerneae, Spironucleus/ Hexamita, Piscinoodinium, Argulus. 
Embora os nematóides sejam comuns em peixes selvagens, necessitam de hospedeiros intermediários, e dificilmente estão presentes em criações intensivas que adotam boas práticas, não sendo possível completar o ciclo biológico do agente (NOGA, 2010b). Os crustáceos Lerneae (figura 33a e 33b) e Argulus (figura 33c e 33d) além de parasitar os peixes, também causam lesões que podem servir de porta de entrada para infecções secundárias de origem bacteriana e também podem ser disseminadores de doenças virais (STECKLER; YANONG, 2012a, 2012b).

Os Diplomonadideos (Spironucleus/Hexamita) são parasitas obrigatórios do trato gastrintestinal de peixes e causam severas lesões na parede do intestino impedindo que haja absorção de nutrientes, levando os animais a óbito, em infestações intensas (GALLANI et al., 2016). Pscinoodinum é um parasita sem hospedeiro específicos responsável por significativos problemas sanitários no Brasil em peixes de consumo de água doce, segundo relato de produtores. Intensas infestações causam altas taxas de mortalidade (MARTINS et al., 2015) se não tratado logo no início. 
Figura 33: (a) Lerneae spp (seta) parasitando Xiphophorus hellerii; (b) Microscopia 4x. Ganchos em forma de âncora que se fixam na pele do peixe; (c) Argulus spp parasitanto Cyprinus carpio; (d) Microscopia 4x. Argulus spp.
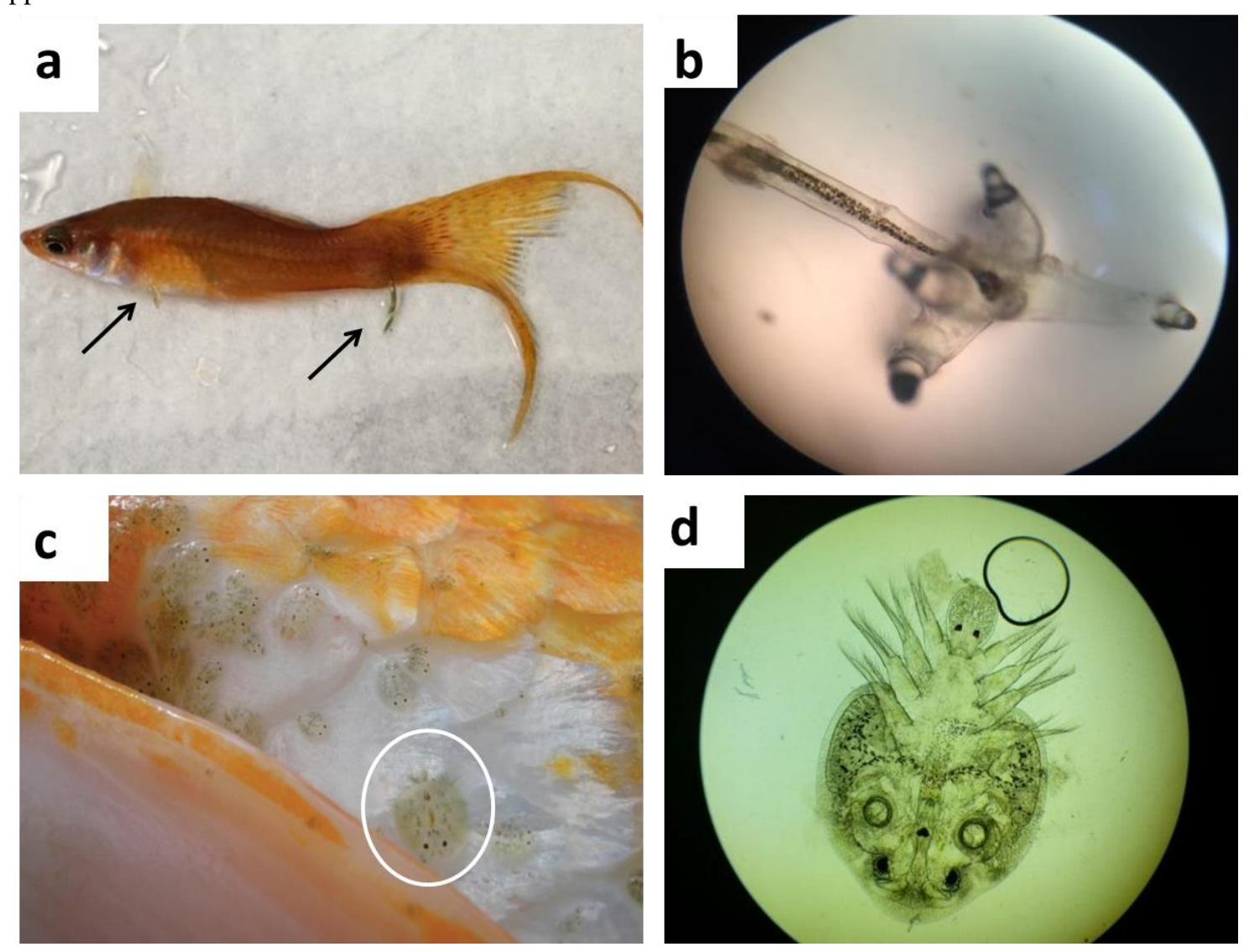

Fonte: Cardoso, 2017

A ocorrência dos parasitas acima citados no estabelecimento em estudo pode ser um indicativo da falta de cuidados no manejo higiênico sanitário dos fornecedores que não adotam boas práticas sanitárias no manejo do plantel, distribuindo animais infestados.

Com relação à ocorrência de parasitas nos peixes de água salgada, obtiveram-se: 43,5\% Cryptocaryon irritans, 23,5\% Uronema sp, 19,5\% Monogênea, 13,5\% Broklynella sp.

Cryptocaryon irritans foi o parasita de maior prevalência nos peixes de água salgada neste estudo, apresentando pontos brancos, denominados trofontes (figura 34b) - fase parasitária do protozoário, corresponde ao agente da doença dos pontos brancos (figura 34a) em peixes de água salgada. Provoca perdas significativas tanto no setor do aquarismo quanto de peixes de produção, em todo mundo, e sua disseminação assim como o I. multifililis é bastante rápida. O diagnóstico precoce e tratamento são necessários, com o intuito de reduzir tais perdas que podem chegar a dizimar plantéis (YANONG, 2009a). 
Figura 34: (a) Doença dos pontos brancos causada por Cryptocaryon irritans no peixe ornamental Zebrassoma xanthurum; (b) Microscopia 40x, raspado de pele. Fase parasitária do protozoário (trofonte).

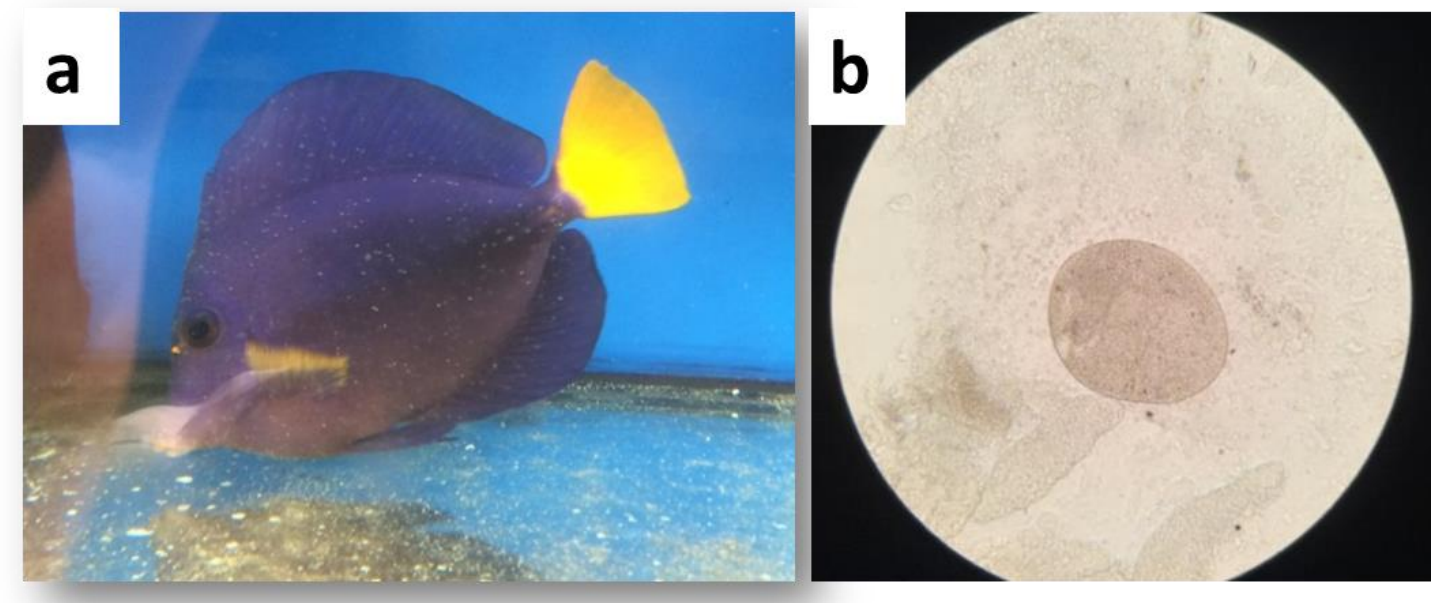

Fonte: Cardoso, 2017

Scuticociliatose é uma doença severa de peixes marinhos causada por protozoários ciliados da classe Scuticociliata, principalmente devido à espécie Uronema sp. É um protozoário de vida livre que parasita superfície da pele (figura 35b), brânquias (figura 35c) e nadadeiras de peixes marinhos (Crosbie; Munday, 1999). É responsável por perdas econômicas significativas em peixes de criação e peixes ornamentais se não tratados precocemente (Bassler, 1983; Cheung et al., 1980; Gill;Callinan, 1997; Noga, 2010).

A patogenicidade desse parasita é mais severa em ambientes com altas concentrações de bactérias, nutrientes e matéria orgânica (Urrutxurtu et al., 2003). O parasita produz proteases responsáveis pela digestão de tecidos do hospedeiro (Al-Marzouk; Azad, 2007), provocando lesões macroscópicas e ulcerativas na superfície da pele (figura 35a) e nadadeiras, exoftalmia, edema na cavidade visceral e lesões nos órgãos (figura 35d).

Uronema $s p$ foi o segundo maior prevalência nos peixes de água salgada. Todos os peixes positivos para Uronema sp eram importados, sugerindo se tratar de uma doença transfronteiriça e extremamente importante de ser considerada no programa de controle sanitário, considerando as lesões graves que provoca, podendo levar os peixes à morte. 
Figura 35: (a) Chromis viridis apresentando lesões ulcerativas hemorrágicas na pele; (b) \{cabeças de flechas\} presença de Uronema sp invadindo o tecido subcutâneo e o músculo esquelético; (c) \{ cabeça da seta \}protozoários invadindo o tecido branquial ; (c) \{asterisco\}com degeneração vacuolar, necrose e $\{$ flechas contínuas \}infiltrado inflamatório composto por granulócitos eosinofílicos; (d) \{cabeça da flecha\} parasitas invadindo a cápsula renal. Corado com hematoxilina-eosina (b-d).
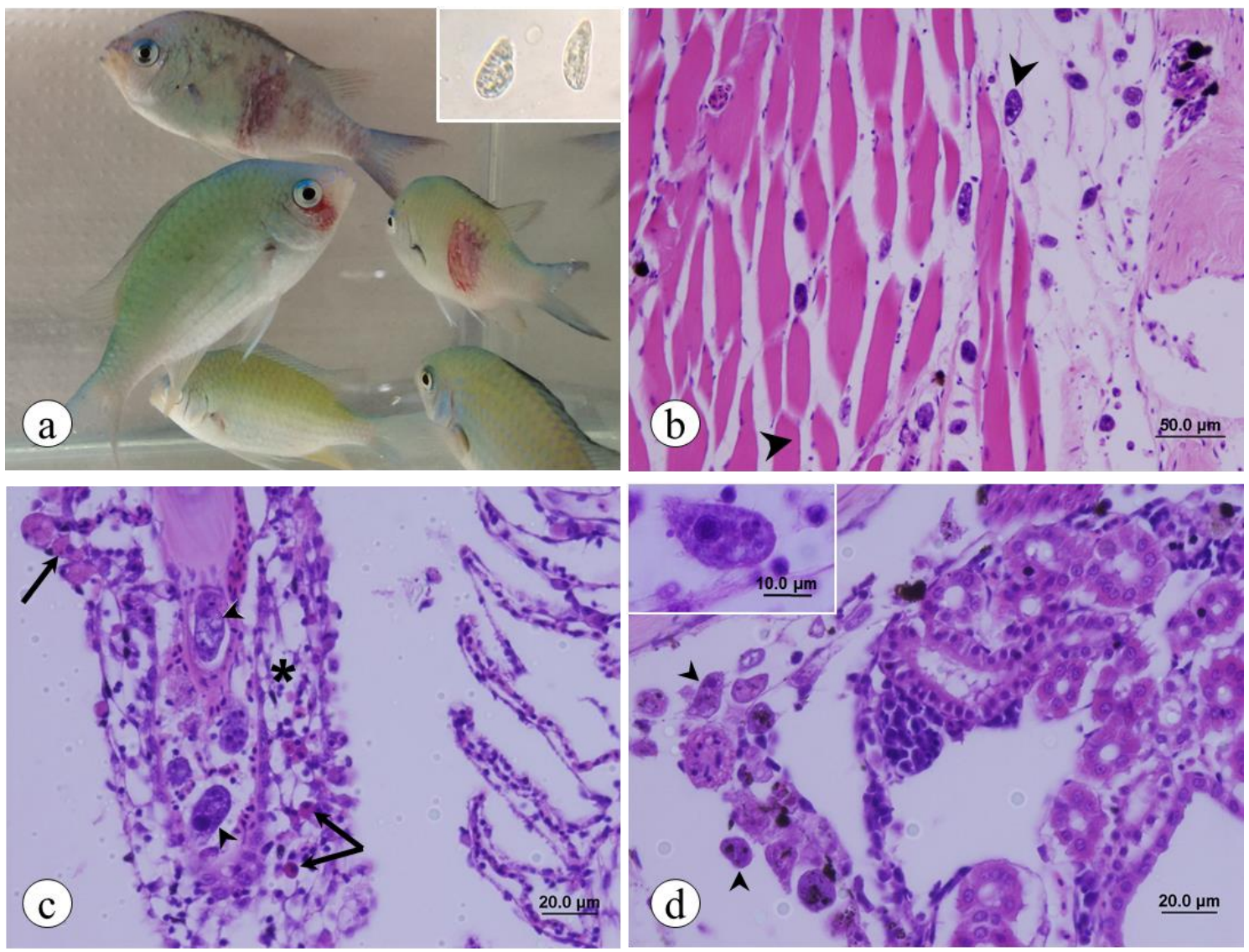

Fonte: Cardoso, 2017

As monogêneas também são problemas em peixes marinhos. Neobenedenia e Benedenia, são dois gêneros de monogêneas da família Capsalidae que uma vez instalados em aquários marinhos, causam problemas crônicos. Primariamente são encontrados na pele e ocasionalmente acomete os olhos de peixes (ROBERTS; PALMEIRO; WEBER, 2009; KERBER et al., 2011; REED; FRANCIS-FLOYD; KLINGER, 2012).

Neobenedenia melleni é uma espécie bastante comum em peixes de recife de corais e pode causar sérias lesões na pele e tem predileção pelos olhos. Tal espécie possui ganchos que causam lesões nos olhos levando à cegueira, infesta diversas espécies de peixes de recife, incluindo membros das famílias Acanthuridae, Ariidae, Balistidae, Diodontidae, Carangidae, Chaetodontidae, Holocentridae, Labridae, Lutjanidae, Malacanthidae, Ostraciidae, Pomadasyidae, Percichthyidae, Poma tomidae, Psettidae, Scatophagidae, Sciaenidae, Serranidae, Sparidae, e Triglidae (NOGA, 2010b). 
Monogênea foi o terceiro gênero de parasitas mais prevalente em peixes de água salgada presentes no estabelecimento utilizado como cenário. Todos os peixes parasitados apresentaram opacidade de córnea (figura 36a) e lesões pelo corpo. O raspado de pele foi analisado microscopicamente e identificou-se Monogênea (figura 36b) sugestivos de Neobenedenia. É um parasita que em intensas infestações provocam prejuízos significativos para o estabelecimento caso o diagnóstico seja tardio e providências não sejam tomadas precocemente. Pelo fato de que todas as espécies de peixes de água salgada sejam importadas, muito provavelmente se trata de uma doença transfronteiriça que passou despercebida pelo período de quarentena.

Figura 36: (a) Pomacanthus semicirculatus com opacidade de ocular; (b) Microscopia 4x. Monogênea sugesttiovo de Neobenedenia melleni
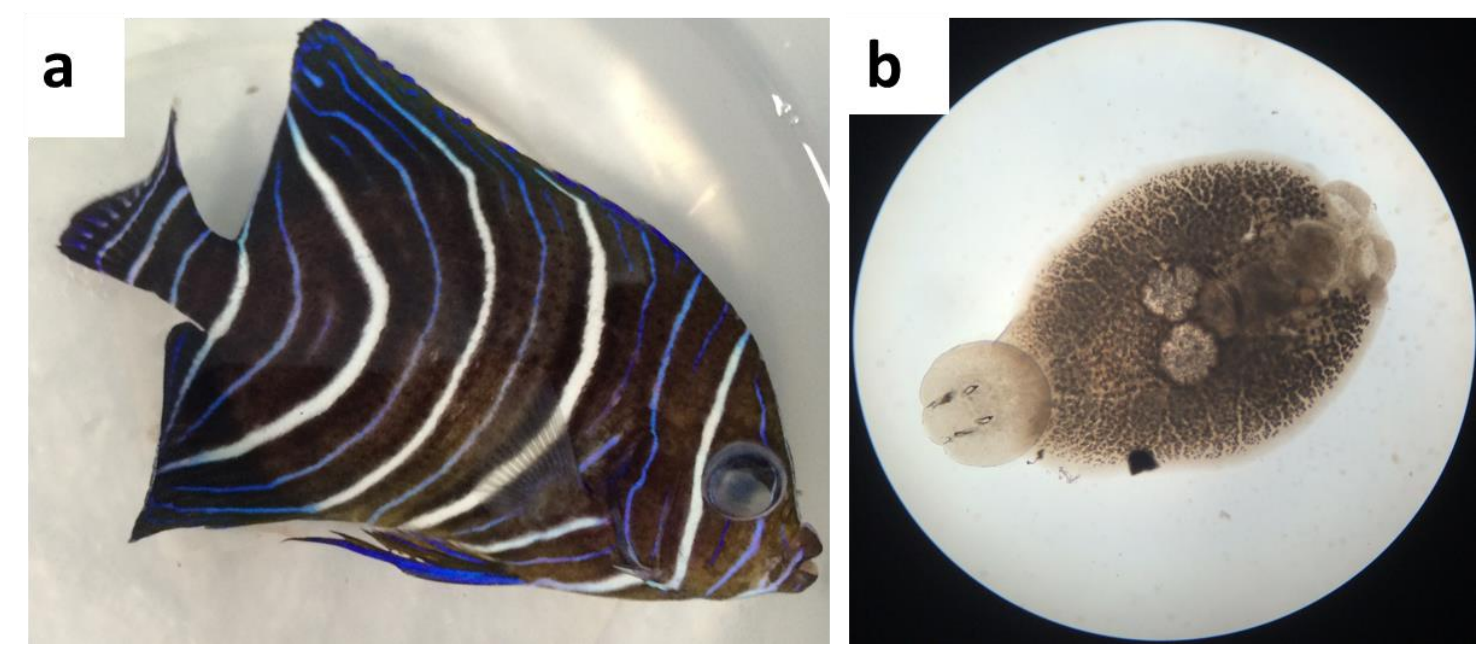

Fonte: Cardoso, 2017

Broklinelose é uma doença causada pelo protozoário marinho Brooklynella hostilis, e está associado a mortalidade aguda em peixes ornamentais. As características morfológicas mais comuns, na identificação microscópica do parasita é achatamento dorsoventral e movimentação lenta. Embora seja uma parasita de brânquias, também pode causar lesões graves na pele (NOGA, 2010b).

Broklynella foi o quarto e último patógeno de peixes de água salgada mais prevalente, acometendo principalmente peixe palhaço (Amphiprion ocellaris) provocando alta taxa de mortalidade. 


\subsection{Medidas Preventivas para os perigos de natureza parasitária em peixes ornamentais}

Para prevenção de doenças de natureza parasitária, o ideal, como já citado anteriormente é adquirir peixes ornamentais de fornecedores que adotem boas práticas de controle sanitário em sua produção. Fornecedores que entreguem animais em condição sanitária aceitável (THILAKARATNE; RAJAPAKSHA; HEWAKOPARA, 2003; PIAZZA et al., 2006; TAVARES-DIAS; LEMOS; MARTINS, 2010; IQBAL; HAROON, 2014; SAHA; BANDYOPADHYAY, 2016).

Muitos peixes podem apresentar aparência saudável, porém poderão ao mesmo tempo, conter parasitas externos invisíveis a olho nu. Considerando esse risco uma importante medida para o controle de parasitas externos em peixes de água salgada é realizar banhos com água doce de até 5 minutos, obtendo o desprendimento de monogêneas, (REED; FRANCIS-FLOYD; KLINGER, 2012), banho curto de formalina de no máximo uma hora para liberação de protozoários ciliados e flagelados (CROSBIE; MUNDAY, 1999) e banhos prolongados de no mínimo 24 horas de sulfato de cobre para parasitas como Ichthyophthirius multifilis e Cryptocaryon irritans (COLORNI, 1987; YANONG, 2009b; WATSON; YANONG, 2011) antes da efetiva entrada dos peixes no sistema produtivo da empresa.

Paralelamente às praticas acima descritas o estabelecimento deve manter rigoroso sistema de higienização de todos os utensílios, instrumentos, equipamentos, recipientes que entram em contato com os animais e a água. Devem ser rigorosamente identificados e individuais para cada sistema. O monitoramento dos parâmetros de qualidade de água devem ser mantidos sob sistemática rotina, com o intuito de manter a excelência de sua qualidade e então manter os animais saudáveis. A água de entrada deve passar por filtros de comprovada eficiência e no sistema de tratamento quando da recirculação da água, deve fazer uso de filtro de luz ultravioleta e ozonização como já comentado anteriormente.

Após assegurar que todas as práticas acima descritas estão garantidas e executadas em rotina, deve-se manter também o monitoramento dos animais alojados no sistema como já descrito no item 2.3.6.3 Armazenamento do Capítulo 02 da presente tese.

E caso haja positividade para algum parasita, investigar sua provável origem, estabelecer ou reforçar medidas de controle e preventivas e realizar o tratamento dos animais acometidos com agentes terapêuticos antiparasitários (KENT et al., 2009b; NOGA, 2010b).

Vale salientar que os agentes terapêuticos citados, formalina e sulfato de cobre e os agentes não citados azul de metileno e verde de malaquita, são proibidos na aquicultura de produção para tratamento de peixes devido as características cancerígenas que possuem. Porém, no 
Brasil os medicamentos LabCon Clean ${ }^{\circledR}$ (Registro no MAPA $n^{\circ}$ 6.211/97) e LabCon Ictio® (Registro no MAPA $n^{\circ}$ 6.210) (BRASIL, 2014, acessado em 19 de setembro de 2017) fabricados pelo laboratório Alcon ${ }^{\circledR}$ possuem os princípios anteriormente citados (azul de metileno, formalina, verde de malaquita e sulfato de cobre) e são indicados no tratamento de ectoparasitas em peixes ornamentais e não serão aqui discutidos os males maiores que cada um deles podem causar, pois não faz parte do escopo do trabalho.

\section{Resumo dos principais perigos e medidas preventivas}

\begin{tabular}{|c|c|c|}
\hline Perigo biológico & Principais Agentes & Medidas Preventivas \\
\hline \multirow{3}{*}{ Parasitários } & $\begin{array}{l}\text { Protozoários de água doce: } \\
\text { Ichthyophthirius } \\
\text { multifilis,Ichthyobodo spp., } \\
\text { Epistylis spp., Chillodonella spp., } \\
\text { Tetrahymena spp., } \\
\text { Piscinoodinium spp., Trichodina } \\
\text { spp., entre outros. } \\
\\
\text { Protozoários de água salgada: } \\
\text { Cryptocaryon irritans, Uronema } \\
\text { spp e outro Scuticociliados, } \\
\text { Broklynella spp., Amyloodinium } \\
\text { spp e outros. }\end{array}$ & $\begin{array}{l}\text { 1) Adquirir animais de fornecedores que } \\
\text { adotem boas práticas de higiene e manejo } \\
\text { em suas instalações; 2) Inspeção visual a } \\
\text { procura de lesões características durante o } \\
\text { recebimento; 3) Banhos com agentes } \\
\text { terapêuticos anti-parasitários antes de } \\
\text { introduzir no sistema como formalina } \\
\text { (aclimatação) e banho de água doce para } \\
\text { peixes marinhos; 4) Banho prolongado em } \\
\text { Sulfato de Cobre quando diagnosticado a } \\
\text { doença (armazenamento); 5) Utilização } \\
\text { de filtro de luz Ultravioleta e Ozonização } \\
\text { na água de circulação; 6) Manter excelente } \\
\text { qualidade de água nos sistemas aquáticos; } \\
\text { 7) Manter os peixes de água salgada em } \\
\text { hipossalinidade (armazenamento). }\end{array}$ \\
\hline & $\begin{array}{l}\text { Metazoários água doce e } \\
\text { salgada: Monogêneas } \\
\text { (Gyrodactylus spp., e } \\
\text { Dactylogyrus spp. Benedenia } \\
\text { spp., Neobenedenia spp.), } \\
\text { Nematóides, Centrocestus spp, } \\
\text { Cestódeos. }\end{array}$ & $\begin{array}{l}\text { 1) Adquirir animais de fornecedores que } \\
\text { adotem boas práticas de higiene e manejo } \\
\text { em suas instalações; 2) Manter os peixes } \\
\text { em água com excelente qualidade de água; } \\
\text { 3) Banhos com agentes terapêuticos } \\
\text { antiparasitários como praziquantel antes de } \\
\text { entrar no sistema em peixes de água doce e } \\
\text { salgada (aclimatação); 4) Banho de água } \\
\text { doce em peixes marinhos antes de } \\
\text { introduzir no sistema (aclimatação); 5) } \\
\text { Manter os peixes de água salgada em } \\
\text { hipossalinidade (armazenamento); 6) } \\
\text { Utilização de filtro de luz Ultravioleta e } \\
\text { Ozonização na água de circulação } \\
\text { (armazenamento). }\end{array}$ \\
\hline & $\begin{array}{l}\text { Crustáceos: Argulus spp., e } \\
\text { Lerneae spp. }\end{array}$ & $\begin{array}{l}\text { 1) Adquirir animais de fornecedores que } \\
\text { adotem boas práticas de higiene e manejo } \\
\text { em suas instalações e que não tenham } \\
\text { histórico de crustáceos parasitas em seus } \\
\text { peixes; 2) Inspeção visual a procura de } \\
\text { lesões características durante o } \\
\text { recebimento;3) Em caso de ocorrência, } \\
\text { tratamento de toda a água com agentes } \\
\text { terapêuticos anti-crustáceos como } \\
\text { Triclorfon (armazenamento); 4) } \\
\text { Utilização de filtro de luz Ultravioleta e } \\
\text { Ozonização na água de circulação. }\end{array}$ \\
\hline
\end{tabular}




\subsection{CONSIDERAÇÕES FINAIS}

De acordo com os dados levantados dos patógenos que ocorreram no estabelecimento utilizado como cenário e literatura científica pesquisada, são inúmeros os perigos de etiologia bacteriana, viral, fúngica e parasitária que acometem os peixes ornamentais. Algumas bactérias possuem inclusive caráter zoonótico, o que coloca em risco os profissionais que manipulam os animais durante o manejo caso cuidados básicos não sejam tomados.

As boas práticas de higiene e manejo, assunto amplamente discutido no Capítulo 02 da presente tese, são a chave para a prevenção e controle das doenças, e é uma etapa chave para criação de programas de autocontrole sanitário e implementação do Sistema APPCC. As boas práticas que possuem medidas preventivas para o controle de doenças devem vir desde os produtores e continuar em todo o elo da cadeia de comercialização minimizando assim o efeito negativo de determinados perigos.

Para os perigos de natureza viral que causam doenças de importância econômica, a prevenção e controle se dá principalmente pela aquisição de fornecedores que se certifiquem de livres de doenças. Muitos perigos biológicos, além dos de natureza viral, são introduzidas nos sistemas aquáticos através da aquisição de animais portadores assintomáticos, que podem manifestar a doença depois de muito tempo da aquisição. Por isso, um período de quarentena prolongado é de extrema importância de acordo com a doença que se quer controlar e finalidade do plantel. Portanto, esse Capítulo lista os principais perigos biológicos de natureza bacteriana, viral, fúngica e parasitária do qual os peixes ornamentais estão susceptíveis e apresenta as principais medidas preventivas para o controle. Esse é o penúltimo passo para que se possa aplicar o Sistema APPCC.

Acredita-se que a correta utilização de tais procedimentos poderá garantir uma redução significativa da disseminação de algumas doenças, e contribuir de forma substancial para a Saúde e Bem Estar dos peixes ornamentais. 


\section{REFERÊNCIAS}

ABD EL-GALIL, M. A. A.; MOHAMED, M. H. First Isolation of Vibrio alginolyticus from Ornamental Bird Wrasse Fish (Gomphosus caeruleus) of the Red Sea in Egypt. Journal of Fisheries and Aquatic Science, v. 7, n. 6, p. 461-467, 2012.

ADEL, M.; GHASEMPOUR, F.; AZIZI, H. R.; SHATERI, M. H.; SAFIAN, A. R. Survey of parasitic fauna of different ornamental freshwater fish species in Iran. Veterinary Research Forum, v. 6, n. 1, p. 75-78, 2015.

AHNE, W.; BJORKLUND, H. V.; ESSBAUER, S.; FIJAN, N.; KURATH, G.; WINTON, J. R. Spring viremia of carp (SVC). Diseases of Aquatic Organisms, v. 52, p. 261-272, 2002. AL-HARBI, A. H.; UDDIN, M. N. Seasonal variation in the intestinal bacterial flora of hybrid tilapia (Oreochromis niloticus x Oreochromis aureus) cultured in earthen ponds in Saudi Arabia. Aquaculture, v. 229, n. 1-4, p. 37-44, 2004.

AL-MARZOUK, A.; AZAD, I. S. Growth kinetics, protease activity and histophagous capability of Uronema sp. infesting cultured silver pomfret Pampus argenteus in Kuwait. Diseases of Aquatic Organisms, v. 76, n. 1, p. 49-56, 2007.

ALEXANDRE, F. A.; FARIA, J. de A. F.; CARDOSO, C. F. Avaliaçao da eficiência da radiação Ultravioleta na esterelização de embalagens plásticas. Ciênc. Agrotec. Lavras, v. 32 , n. 5, p. 1524-1530, 2008.

ALEXANDRINO, A. C.; RANZANI-PAIVA, M. J. T.; ROMANO, L. A. Identificación de viremia primaveral de la carpa (VPC) Carassius auratus em San Pablo. Revista Ceres, v. 45, n. 258 , p. $125-137,1998$.

ALMEIRA, C. R.; RASZL, S. M.; ORE, N. D. B.; JÚNIOR, G. A. da C. Análise de Perigos e Pontos Críticos de Controle. In: OPS, O. P. DA S.; INPPAZ, I. P. DE P. DE A. E Z. (Ed.).

HACCP: Ferramenta Essencial para Inocuidade dos Allimentos. [s.l: s.n.]p. 1-167.

ALTUN, S.; GÜL BÜYÜKEKIZ, A.; DUMAN, M.; ÖZGÜR ÖZYIĞIT, M.; KARATAŞ, S.; TURGAY, E. Isolation of Shewanella putrefaciens from goldfish (Carassius auratus auratus). Israeli Journal of Aquaculture - Bamidgeh, v. 66, 2014.

ANNIE SELVA SONIA, G.; LIPTON, A. P. Pathogenicity and antibiotic susceptibility of 
Vibrio species isolated from the captive-reared tropical marine ornamental blue damsel fish, Pomacentrus caeruleus (Quoy and Gaimard, 1825). Indian Journal of Marine Sciences, v. 41, n. 4, p. 348-354, 2012.

BASSLER, G. Uronema marinum, a new and common parasite on tropical saltwater fishes. Freshw. Mar. Aquar., v. 6, p. 78-79, 1983.

BEAZ-HIDALGO, R.; AGÜERIA, D.; LATIF-EUGENÍN, F.; YEANNES, M. I.; FIGUERAS, M. J. Molecular characterization of Shewanella and Aeromonas isolates associated with spoilage of Common carp (Cyprinus carpio). FEMS Microbiology Letters, v. 362, n. 1, p. 1-8, 2015.

BECKER, J. A.; TWEEDIE, A.; RIMMER, A.; LANDOS, M.; LINTERMANS, M.; WHITTINGTON, R. J. Incursions of Cyprinid herpesvirus 2 in goldfish populations in Australia despite quarantine practices. Aquaculture, v. 432, p. 53-59, ago. 2014.

BRASIL. Portaria n⿳0 19, de 4 de fevereiro de 2015. Lista de doenças de notificação obrigatória por grupo taxonômico.Diário Oficial [da] União,Brasilia, DF, BrasilMinistério da Pesca e Aquicultura, , 2015. .

BRASIL, M. da A. P. e A. Portaria $\mathbf{N}^{\mathbf{0}}$ 46, Sistema de Análise de Perigos e Pontos Críticos de ControleDiário Oficial [da] União,Brasília, DF, 10 de fev. de 1998, 1998.

BRASIL, M. da A. P. e A. Relatório de produtos com licença vigente.

CAMUS, a C.; DILL, J. a; MCDERMOTT, a J.; CLAUSS, T. M.; BERLINER, a L.; BOYLAN, S. M.; SOTO, E. Francisella noatunensis subsp. orientalis infection in Indo-Pacific reef fish entering the United States through the ornamental fish trade. Journal of fish diseases, v. 36, n. 7, p. 681-4, jul. 2013.

CARDOSO, P. H. M.; BALIAN, S. C. Lymphocystis vírus em peixes ornamentais importados para o Brasil. Revista de Educação Continuada em Medicina Veterinária e Zootecnia, v. 14, n. 1, p. 6-11, 2016.

CARDOSO, P. H. M.; BALIAN, S. de C.; MAGANHA, S. R. de L.; SOUZA, R. L. M. de. First report of Megalocytivirus in Red Piranhas ( Pygocentrus nattereri ) by Molecular Diagnosis in Brazil. International Journal of Avian \& Wildlife Biology, v. 2, n. 3, p. 2-4, 2017a. 
CARDOSO, P. H. M.; COSTA, A. R. da; PESTELli, M.; BALIAN, S. de C. Relato de caso de parasitismo por Monogênea no peixe ornamental Polypterus palmas no Brasil. Revista de Educacao Continuada do CRMV-SP, v. 15, n. 1, p. 30-36, 2017 b.

CHEN, Y. S.; LIU, Y. C.; YEN, M. Y.; WANG, J. H.; WANG, J. H.; WANN, S. R.; CHENG, D. L. Skin and soft-tissue manifestations of Shewanella putrefaciens infection.

Clinical infectious diseases : an official publication of the Infectious Diseases Society of America, v. 25, n. 2, p. 225-229, 1997.

CHEUNG, J.; FUNG, B.; IP, W.; CHOW, S.-P. Mycobacterium marinum infection of the hand and wrist. Journal of Orthopaedic Surgery, v. 20, n. 2, p. 214-218, 2012.

CHEUNG, P. J.; NIGRELLI, R. F.; RUGGIERI, G. D. Studies on the morphology of Uronema marinum Dujardin (Ciliatea: Uronematidae) with a description of the histopathology of the infection in marine fishes. Journal of Fish Diseases, v. 3, n. 4, p. 295-303, jul. 1980.

CITARASU, T.; ALFRED DHAS, K.; VELMURUGAN, S.; THANGA VIJI, V.; KUMARAN, T.; MICHAEL BABU, M.; SELVARAJ, T. Isolation of Aeromonas hydrophila from infected ornamental fish hatchery duriing massive outbreaks. International Journal of Current Research, v. 2, n. 1, p. 37-41, 2011.

COLORNI, A. Biology of Cryptocaryon irritans and strategies for its control. Aquaculture, v. 67, p. $236-237,1987$.

COLQUHOUN, D. J.; DUODU, S. Francisella infections in farmed and wild aquatic organisms. Veterinary Research, v. 42, n. 1, p. 7-15, jan. 2011.

CROSBIE, P. B. B.; MUNDAY, B. L. Environmental factors and chemical agents affecting the growth of the pathogenic marine ciliate Uronema nigricans. Diseases of Aquatic Organisms, v. 36, n. 3, p. 213-219, 1999.

CROSBY, T. C.; HILL, J. E.; MARTINEZ, C. V; WATSON, C. a; POUDER, D. B.; ROY, P. E. On-Farm Transport of Ornamental Fish 1. IFAS Extension Univserity of Florida, v. FA119, p. 1-6, 2014.

DAVISON, A. J.; KUROBE, T.; GATHERER, D.; CUNNINGHAM, C.; KORF, I.; FUKUDA, H.; HEDRICK, R. P. Comparative Genomics of Carp Herpesviruses. Journal of Virology, v. 87, n. 5, p. 2908-2922, 2013. 
DECLERCQ, A. M.; CHIERS, K.; VAN DEN BROECK, W.; DEWULF, J.; EECKHAUT, V.; CORNELISSEN, M.; BOSSIER, P.; HAESEBROUCK, F.; DECOSTERE, A. Interactions of highly and low virulent Flavobacterium columnare isolates with gill tissue in carp and rainbow trout. Veterinary Research, v. 46, 2015.

DECLERCQ, A. M.; HAESEBROUCK, F.; VAN DEN BROECK, W.; BOSSIER, P.; DECOSTERE, A. Columnaris disease in fish: a review with emphasis on bacterium-host interactions. Veterinary Researchesearch, v. 44, p. 27, jan. 2013.

ESSA, M. A. A.; KENAWY, A. M.; EL-GAWAD, D. M. A. Epizootiological and Histopathological Studies on Mycobacteriosis in Some Ornamental Fishes. Global Veterinaria, v. 3, n. 2, p. 137-143, 2009.

ESSBAUER, S.; AHNE, W. Viruses of lower vertebrates. Journal of Veterinary Medicine, Series B, v. 48, n. 6, p. 403-475, 2001.

FRANCIS-FLOYD, R.; REED, P. Ichthyophthirius Multifiliis ( White Spot ) Infections in Fish. IFAS Extension Univserity of Florida, v. CIR20, p. 1-5, 2009.

GAIKOWSKI, M. P.; LARSON, W. J.; STEUER, J. J.; GINGERICH, W. H. Validation of two dilution models to predict chloramine-T concentrations in aquaculture facility effluent. Aquacultural Engineering, v. 30, n. 3-4, p. 127-140, 2004.

GALLANI, S. U.; SEBASTI??O, F. de A.; VALLAD??O, G. M. R.; BOARATTI, A. Z.; PILARSKI, F. Pathogenesis of mixed infection by Spironucleus sp. and Citrobacter freundii in freshwater angelfish Pterophyllum scalare. Microbial Pathogenesis, v. 100, p. 119-123, 2016.

GILL, P. A.; CALLINAN, R. B. Ulcerative dermatitis associated with Uronema sp infection of farmed sand whiting Silago ciliata. Australian Veterinary Journal, v. 75, n. 5, p. 1997, 1997.

GOTESMAN, M.; KATTLUN, J.; BERGMANN, S. M.; EL-MATBOULI, M. CyHV-3: the third cyprinid herpesvirus. Diseases of Aquatic Organisms, v. 105, n. 2, p. 163-74, 22 jul. 2013.

GRIM, C. J.; KOZLOV, E. V.; SHA, J.; FITTS, E. C.; VAN LIER, C. J.; KIRTLEY, M. L.; JOSEPH, S. J.; READ, T. D.; BURD, E. M.; TALL, B. D.; JOSEPH, S. W.; HORNEMAN, 
A. J.; CHOPRA, A. K.; SHAK, J. R. Characterization of Aeromonas hydrophila wound pathotypes by comparative genomic and functional analyses of virulence genes. mBio, v. $4, \mathrm{n}$. 2, p. 1-13, 2013.

GUZ, L.; PUK, K.; WALCZAK, N.; ONISZCUZUK, T.; ONISZCUZUK, A. Effect of dietary supplementation with Echinacea purpurea on vaccine efficacy against infection with Flavobacterium columnare in zebrafish (Danio rerio). Pol J Vet Sci, v. 17, n. 4, p. 583-6, 2014.

HANSON, L.; DISHON, A.; KOTLER, M. Herpesviruses that Infect Fish. Viruses, v. 1, p. 2160-2191, 2011.

HARTMAN, K. H.; YANONG, R. P. E.; POUDER, D. B.; PETTY, B. D.; FRANCISFLOYD, R.; RIGGS, A. C. Koi Herpesvirus ( KHV ) Disease. University of Florida IFAS Extension, p. 1-9, 2008.

HASHEM, M.; EL-BARBARY, M. Vibrio harveyi infection in Arabian Surgeon fish (Acanthurus sohal) of red sea at hurghada, Egypt. Egyptian Journal of Aquatic Research, v. 39, n. 3, p. 199-203, 2013.

HAWKE, J. P.; KENT, M.; ROGGE, M.; BAUMGARTNER, W.; WILES, J.; SHELLEY, J.; CHRISTINE SAVOLAINEN, L.; WAGNER, R.; MURRAY, K.; PETERSON, T. S. Edwardsiellosis caused by Edwardsiella ictaluri in laboratory populations of Zebrafish Danio rerio. Journal of Aquatic Animal Health, v. 25, n. March 2015, p. 171-183, 2013.

HUMPHREY, J. D.; LANCASTER, C.; GUDKOVS, N.; MCDONALD, W. Exotic bacterial pathogens Edwardsiella tarda and Edwardsiella ictaluri from imported ornamental fish Betta splendens and Puntius conchonius, respectively: isolation and quarantine significance. Australian Veterinary Journal, v. 63, p. 369-371, 1986.

IQBAL, Z.; HAROON, F. Parasitic Infections of Some Freshwater Ornamental Fishes Imported in Pakistan. Pakistan J Zool, v. 46, n. 3, p. 651-656, 2014.

JIANG, R. H. Y.; DE BRUIJN, I.; HAAS, B. J.; BELMONTE, R.; LÖBACH, L.; CHRISTIE, J.; VAN DEN ACKERVEKEN, G.; BOTTIN, A.; BULONE, V.; DÍAZ-MORENO, S. M.; DUMAS, B.; FAN, L.; GAULIN, E.; GOVERS, F.; GRENVILLE-BRIGGS, L. J.; HORNER, N. R.; LEVIN, J. Z.; MAMMELLA, M.; MEIJER, H. J. G.; MORRIS, P.; NUSBAUM, C.; OOME, S.; PHILLIPS, A. J.; VAN ROOYEN, D.; RZESZUTEK, E.; SARAIVA, M.; 
SECOMBES, C. J.; SEIDL, M. F.; SNEL, B.; STASSEN, J. H. M.; SYKES, S.; TRIPATHY, S.; VAN DEN BERG, H.; VEGA-ARREGUIN, J. C.; WAWRA, S.; YOUNG, S. K.; ZENG, Q.; DIEGUEZ-URIBEONDO, J.; RUSS, C.; TYLER, B. M.; VAN WEST, P. Distinctive Expansion of Potential Virulence Genes in the Genome of the Oomycete Fish Pathogen Saprolegnia parasitica. PLoS Genetics, v. 9, n. 6, 2013.

KENT, M. L.; FEIST, S. W.; HARPER, C.; HOOGSTRATEN-MILLER, S.; LAW, J. Mac; SÁNCHEZ-MORGADO, J. M.; TANGUAY, R. L.; SANDERS, G. E.; SPITSBERGEN, J. M.; WHIPPS, C. M. Recommendations for control of pathogens and infectious diseases in fish research facilities. Comparative Biochemistry and Physiology Part C Toxicology Pharmacology, v. 149, n. 2, p. 240-248, mar. 2009.

KERBER, C. E.; SANCHES, E. G.; SANTIAGO, M.; LUQUE, J. L. First record of Neobenedenia melleni (Monogenea: Capsalidae) in sea-farmed cobia (Rachycentron canadum) in Brazil. Revista Brasileira de Parasitologia Veterinária, v. 20, n. March 2010, p. 331-333, 2011.

LEHANE, L.; RAWLIN, G. T. Topically acquired bacterial zoonoses from fish: a review. Medical journal of Australia, v. 173, n. 5, p. 256-9, set. 2000.

LEWBART, G. A. Bacterial and Ornamental Fish. In: Seminars in Avian and Exotic Pet Medicine, 1, Anais. 2001.

LEWISCH, E.; DRESSLER, A.; SALEH, M. Francisellosis in ornamental African cichlids in Austria. Bull. Eur. Ass. Fish Patholl., v. 34, n. 2, p. 63-70, 2014.

LOWRY, T.; SMITH, S. A. Vet Med Today: Zoonosis Update. v. 231, n. 6, p. 876-880, 2007.

MARTÍNEZ-MURCIA, a J.; SAAVEDRA, M. J.; MOTA, V. R.; MAIER, T.; STACKEBRANDT, E.; COUSIN, S. Aeromonas aquariorum sp. nov., isolated from aquaria of ornamental fish. International journal of systematic and evolutionary microbiology, $\mathrm{v}$. 58, n. Pt 5, p. 1169-75, maio 2008.

MARTINS, M. .; MOURINO, J. L. .; FEZER, G. .; BUGLIONE NETO, C. .; GARCIA, P.; SILVA, B. .; JATOBÁ, A.; VIEIRA, F. . Isolation and experimental infection with Vibrio alginolyticus in the sea horse , Hippocampus reidi Ginsburg, 1933 ( Osteichthyes : Syngnathidae ) in Brazil. Brazilian Journal of Biology, v. 70, n. 1, p. 205-209, 2010. 
MARTINS, M. L.; CARDOSO, L.; MARCHIORI, N.; BENITES DE PÁDUA, S. Protozoan infections in farmed fish from Brazil: diagnosis and pathogenesis. Brazilian Journal of Veterinary Parasitology, v. 24, n. 1, p. 1-20, 2015.

MCDERMOTT, C.; PALMEIRO, B. Selected emerging infectious diseases of ornamental fish. The veterinary clinics of North America. Exotic animal practice, v. 16, n. 2, p. 261$82,2013$.

MEHRDANA, F.; JENSEN, H.; KANIA, P.; BUCHMANN, K. Import of exotic and zoonotic trematodes (Heterophyidae: Centrocestus sp.) in Xiphophorus maculatus: Implications for ornamental fish import control in Europe. Acta Parasitologica, v. 59, n. 2, p. 276-283, 2014.

NISHA, R. G.; RAJATHI, V.; MANIKANDAN, R.; PRABHU, N. M. Isolation of Plesiomonas shigelloides from infected cichlid fishes using 16S rRNA characterization and its control with probiotic Pseudomonas sp. Acta Scientiae Veterinariae, v. 42, n. 1, p. 1-7, 2014.

NOGA, E. J. Fish disease: diagnosis and treatment, second edition. Second ed. Iowa: Willey - Blackwell, 2010.

OATA, O. A. T. A. Biossecurity and the ornamental fish industry. [s.l: s.n.].

OIE, W. O. for A. H. Methods for Disinfection of Aquaculture Establishments. In: Manual of Diagnostic Tests for Aquatic Animals 2014. [s.l: s.n.]p. 28-40.

OIE, W. O. for A. H. Diseases listed by the Oie. In: Aquatic Animal Heath Code. 2014. ed. [s.1.] OIE, 2014. p. 7-8.

PARK, J.; KIM, P.-K.; LIM, T.; DANIELS, H. V. Ozonation in seawater recirculating systems for black seabream Acanthopagrus schlegelii (Bleeker): Effects on solids, bacteria, water clarity, and color. Aquacultural Engineering, v. 55, p. 1-8, 2013. PATE, M.; JENČIČ, V.; ŽOLNIR-DOVČ, M.; OCEPEK, M. Detection of mycobacteria in aquarium fish in Slovenia by culture and molecular methods. Diseases of Aquatic Organisms, v. 64, n. Lucas 1989, p. 29-35, 2005.

PEELER, E. J.; FEIST, S. W. Human intervention in freshwater ecosystems drives disease emergence. Freshwater Biology, v. 56, p. 705-716, 2011.

PĘKALA, A.; KOZIŃSKA, A.; PAŹDZIOR, E.; GŁOWACKA, H. Phenotypical and 
genotypical characterization of Shewanella putrefaciens strains isolated from diseased freshwater fish. Journal of Fish Diseases, v. 38, n. 3, p. 283-293, mar. 2015.

PIAZZA, R. S.; MARTINS, M. L.; GUIRALDELLI, L.; YAMASHITA, M. M. Parasitic Diseases of Freshwater Ornamental Fishes. B. Inst. Pesca., v. 32, n. 1, p. 51-57, 2006. POWELL, A.; CHINGOMBE, P.; LUPATSCH, I.; SHIELDS, R. J.; LLOYD, R. The effect of ozone on water quality and survival of turbot (Psetta maxima) maintained in a recirculating aquaculture system. Aquacultural Engineering, v. 64, p. 20-24, 2015.

PREARO, M.; ZANONI, R. G.; CAMPO DALL\&APOS;ORTO, B.; PAVOLETTI, E.; FLORIO, D.; PENATI, V.; GHITTINO, C. Mycobacterioses: Emerging pathologies in aquarium fish. Veterinary Research Communications, v. 28, n. July 2001, p. 315-317, 2004.

RAJA, K.; FERNANDO, O. J.; THAVASI, .R.; JAYALAKSMI, .S.; T.BALASUBRAMANIAN. Diversity of Bacterial Populations in Recirculating Marine Aquarium with Different Marine Ornamental Fishes. Research Journal of Microbiology, v. 1, n. 5, p. 448-452, 1 maio 2006.

REED, P.; FRANCIS-FLOYD, R.; KLINGER, R. Monogenean Parasites of FishUniversity of Florida IFAS Extension, 2012. .

ROBERTS-THOMSON, A.; BARNES, A.; FIELDER, D. S.; LESTER, R. J. G.; ADLARD, R. D. Aerosol dispersal of the fish pathogen, Amyloodinium ocellatum. Aquaculture, v. 257, n. 1-4, p. 118-123, jun. 2006.

ROBERTS, H. E.; PALMEIRO, B.; WEBER, E. S. Bacterial and parasitic diseases of pet fish. The veterinary clinics of North America. Exotic Animal Practice, v. 12, n. 3, p. 60938, Table of Contents, set. 2009.

SAHA, M.; BANDYOPADHYAY, P. K. Seasonal incidence of protozoan parasitic infestation in ornamental fishes of West Bengal, India. Journal of Parasitic Diseases, 28 set. 2016.

SANDERS, G. E.; BATTS, W. N.; WINTON, J. R. Susceptibility of Zebrafish (Danio rerio) to a Model Pathogen, Spring Viremia of Carp Virus. Comparative Medicine, v. 53, n. 5, p. 514-521, 2003. 
SHARRER, M. J.; SUMMERFELT, S. T. Ozonation followed by ultraviolet irradiation provides effective bacteria inactivation in a freshwater recirculating system. Aquacultural Engineering, v. 37, n. 2, p. 180-191, 2007.

SMAIL, D. A.; GRANT, R.; SIMPSON, D.; BAIN, N.; HASTINGS, T. S. Disinfectants against cultured Infectious Salmon Anaemia (ISA) virus: The virucidal effect of three iodophors, chloramine $\mathrm{T}$, chlorine dioxide and peracetic acid/hydrogen peroxide/acetic acid mixture. Aquaculture, v. 240, n. 1-4, p. 29-38, 2004.

SREEDHARAN, K.; PHILIP, R.; SINGH, I. S. B. Isolation and characterization of virulent Aeromonas veronii from ascitic fluid of oscar Astronotus ocellatus showing signs of infectious dropsy. Diseases of Aquatic Organisms, v. 94, n. 1, p. 29-39, 2011.

SRIWANAYOS, P.; FRANCIS-FLOYD, R.; STIDWORTHY, M. F.; PETTY, B. D.; KELLEY, K.; WALTZEK, T. B. Megalocytivirus infection in orbiculate batfish Platax orbicularis. Diseases of Aquatic Organisms, v. 105, p. 1-8, 2013.

STECKLER, N.; YANONG, R. P. E. Argulus ( Fish Louse ) Infections in Fish. University of Florida IFAS Extension, v. FA184, p. 1-5, 2012a.

STECKLER, N.; YANONG, R. P. E. Lernaea (Anchorwerm) infestations in fish. IFAS Extension Univserity of Florida, v. FA185, p. 1-4, 2012b.

SUMMERFELT, S. T. Ozonation and UV irradiation - An introduction and examples of current applications. Aquacultural Engineering, v. 28, n. 1-2, p. 21-36, 2002.

SUMMERFELT, S. T.; SHARRER, M. J.; TSUKUDA, S. M.; GEARHEART, M. Process requirements for achieving full-flow disinfection of recirculating water using ozonation and UV irradiation. Aquacultural Engineering, v. 40, n. 1, p. 17-27, 2009.

SUZUKI, M.; SUZUKI, S.; MATSUI, M.; HIRAKI, Y.; KAWANO, F.; SHIBAYAMA, K. Genome Sequence of a Strain of the Human Pathogenic Bacterium Pseudomonas alcaligenes That Caused Bloodstream Infection. Genome Announcements, v. 1, n. 5, p. e00919-13e00919-13, 31 out. 2013.

TAVARES-DIAS, M.; LEMOS, J. R.; MARTINS, M. L. Parasitic fauna of eight species of ornamental freshwater fish species from the middle Negro River in the Brazilian Amazon Region. BrazilianJournal of Veterinary Parasitology, v. 19, n. 2, p. 103-107, 2010. 
TENDENCIA, E. a. The first report of Vibrio harveyi infection in the sea horse Hippocampus kuda Bleekers 1852 in the Philippines. Aquaculture Research, v. 35, n. 13, p. 1292-1294, nov. 2004.

THILAKARATNE, I. D. S. I. P.; RAJAPAKSHA, G.; HEWAKOPARA, A. Parasitic infections in freshwater ornamental fish in Sri Lanka. Disease of Aquatic Organisms, v. 54, p. 157-162, 2003.

TUKMECHI, A.; HOBBENAGHI, R.; RAHMATI HOLASOO, H.; MORVARIDI, A. Streptococcosis in a pet Fish, Astronotus ocellatus: A Case Study. International Journal of Biological and Life Sciences, v. 1, n. 1, p. 30-31, 2009.

URRUTXURTU, I.; ORIVE, E.; SOTA, A. de la. Seasonal dynamics of ciliated protozoa and their potential food in an eutrophic estuary (Bay of Biscay). Estuarine, Coastal and Shelf Science, v. 57, n. 5-6, p. 1169-1182, ago. 2003.

VAN WEST, P. Saprolegnia parasitica, an oomycete pathogen with a fishy appetite: new challenges for an old problem. Mycologist, v. 20, p. 99-104, 2006.

VERMA, D. .; RATHORE, G.; P.K, P.; SOOD, N.; PUNIA, P. Isolation and characterization of Flavobacterium columnare from freshwater ornamental goldfish Carassius auratus. $\mathbf{J}$ Environ Biol, v. 36, n. 2, p. 433-9, 2015.

WATSON, C.; YANONG, R. P. E. Use of Copper in Freshwater Aquaculture and Farm Ponds. IFAS Extension Univserity of Florida, v. FA13, p. 1-2, 2011.

WEBER, E. S.; WALTZEK, T. B.; YOUNG, D. a; TWITCHELL, E. L.; GATES, A. E.; VAGELLI, A.; RISATTI, G. R.; HEDRICK, R. P.; FRASCA, S. Systemic iridovirus infection in the Banggai cardinalfish (Pterapogon kauderni Koumans 1933). Journal of Veterinary Diagnostic Investigation : Official Publication of the American Association of Veterinary Laboratory Diagnosticians, Inc, v. 21, p. 306-320, 2009.

WHIPPS, C. M.; LIEGGI, C.; WAGNER, R. Mycobacteriosis in zebrafish colonies. ILAR Journal, v. 53, n. 2, p. 95-105, jan. 2012.

WHITTINGTON, R. J.; BECKER, J. a; DENNIS, M. M. Iridovirus infections in finfish critical review with emphasis on ranaviruses. Journal of Fish Diseases, v. 33, p. 95-122, 2010 . 
WHITTINGTON, R. J.; CHONG, R. Global trade in ornamental fish from an Australian perspective: the case for revised import risk analysis and management strategies. Preventive Veterinary Medicine, v. 81, n. 1-3, p. 92-116, 14 set. 2007.

WONGLAPSUWAN, M.; KONGMEE, P.; SUANYUK, N.; CHOTIGEAT, W. Roles of phagocytosis activating protein (PAP) in Aeromonas hydrophila infected Cyprinus carpio. Developmental \& Comparative Immunology, v. 59, p. 25-33, 2016.

WU, T.-S.; CHIU, C.-H.; YANG, C.-H.; LEU, H.-S.; HUANG, C.-T.; CHEN, Y.-C.; WU, T.L.; CHANG, P.-Y.; SU, L.-H.; KUO, A.-J.; CHIA, J.-H.; LU, C.-C.; LAI, H.-C. Fish tank granuloma caused by Mycobacterium marinum. PloS One, v. 7, n. 7, p. e41296, jan. 2012.

YANONG, R. P. E. Cryptocaryon irritans Infections ( Marine White Spot Disease ) in Fish. IFAS Extension Univserity of Florida, v. FA164, p. 1-9, 2009a.

YANONG, R. P. E. Use of copper in Marine Aquaculture and Aquarium Systems. IFAS Extension Univserity of Florida, v. FA165, p. 1-6, $2009 \mathrm{~b}$.

YANONG, R. P. E. Lymphocystis Disease in Fish. IFAS Extension Univserity of Florida, v. FA181, p. 1-4, 2013.

YANONG, R. P. E.; POUDER, D. B. Association of Mycobacteria in Recirculating Aquaculture Systems and Mycobacterial Disease in Fish. Journal of Aquatic Animal Health, v. 22, p. 219-223, 2010.

YANONG, R. P. E.; WALTZEK, T. B. Megalocytivirus Infections in Fish, with Emphasis on Ornamental Species 1.

YUCEL, N.; ASLIM, B.; BEYATLI, Y. Prevalence and resistance to antibiotics for Aeromonas species isolated from retail fish in Turkey. Journal of Food Quality, v. 28, p. 313-324, 2005.

ZAFAR, I.; SHEIKH, U.; MUGHAL, R. Fungal Infections in Some Economically Important Freshwater Fishes. Pakistan Veterinary Journal, v. 8318, n. 2010, p. 422-426, 2012. 


\section{APÊNDICES}

Apêndice 8: Isolados bacterianos em amostras de peixes de água doce

\begin{tabular}{|c|c|c|c|}
\hline Agente & Qtde & Espécie Acometida & Tipo de lesão \\
\hline \multirow{18}{*}{ Aeromonas hydrophilla } & 1 & Amphilophus labiatus & Lesão ocular e septicemia \\
\hline & 35 & Carassius auratus & Lesão ocular e septicemia \\
\hline & 4 & Cichlasom meeki & Lesão ocular e septicemia \\
\hline & 3 & Cichlasoma salvini & Lesão ocular e septicemia \\
\hline & 10 & Ciprinus carpio & Lesão de pele \\
\hline & 1 & Cyphotilapia frontosa & Septicemia \\
\hline & 1 & Betta splendens & Septicemia \\
\hline & 3 & Danio rerio & Lesão de pele \\
\hline & 3 & Mikrogeophagus altispinosus & Lesão de pele e septicemia \\
\hline & 1 & Misgurnus anguillicaudatus & Lesão de pele e septicemia \\
\hline & 1 & Moenkhausia costae & Septicemia \\
\hline & 1 & Puntius conchonius & Septicemia \\
\hline & 1 & Puntigrus tetrazona & Septicemia \\
\hline & 5 & Polypterus senegalus & Lesão de pele \\
\hline & 4 & Trichogaster lalius & Septicemia \\
\hline & 2 & Trichogaster trichopterus & Septicemia \\
\hline & 8 & Trichopodus trichopterus & Septicemia \\
\hline & 1 & Xiphophorus maculatus & Septicemia \\
\hline
\end{tabular}

TOTAL

85

\begin{tabular}{l|l|l}
1 & Amphilophus labiatus & Lesão ocular e septicemia \\
\hline
\end{tabular}




\begin{tabular}{|c|c|c|c|}
\hline \multirow{24}{*}{ Aeromonas veroni } & 4 & Barbodes semifasciolatus & Septicemia \\
\hline & 21 & Carassius auratus & Lesão ocular e septicemia \\
\hline & 1 & Cichlasom meeki & Lesão ocular e septicemia \\
\hline & 6 & Cichlasoma salvini & Lesão ocular e septicemia \\
\hline & 24 & Ciprinus carpio & Lesão de pele \\
\hline & 1 & Cyphotilapia frontosa & Septicemia \\
\hline & 6 & Danio rerio & lesão de pele \\
\hline & 1 & Demasoni pombo & Septicemia \\
\hline & 1 & Hemiodus gracilis & Septicemia \\
\hline & 1 & Mastacembelus erythrotaenia & Septicemia \\
\hline & 1 & Maylandia zebra & Septicemia \\
\hline & 4 & Mikrogeophagus altispinosus & Septicemia \\
\hline & 1 & Misgurnus anguillicaudatus & Septicemia \\
\hline & 2 & Pangasius hypophthalmus & Septicemia \\
\hline & 2 & Poecilia reticulata & Septicemia \\
\hline & 2 & Polypterus senegalus & Lesão de pele \\
\hline & 2 & Pterophyllum scalare & Septicemia \\
\hline & 1 & Puntius conchonius & Septicemia \\
\hline & 4 & Symphysodon discus. & Lesão ocular e septicemia \\
\hline & 1 & Trichogaster lalius & Septicemia \\
\hline & 2 & Trichopodus leerii & Septicemia \\
\hline & 10 & Trichopodus trichopterus & Septicemia \\
\hline & 1 & Tropheus moorii & Septicemia \\
\hline & 1 & Xiphophorus maculatus & Septicemia \\
\hline TOTAL & \multicolumn{3}{|c|}{101} \\
\hline Aeromonas caviae & 2 & Carassius auratus & Lesão ocular e septicemia \\
\hline
\end{tabular}




\begin{tabular}{|c|c|c|c|}
\hline & 2 & Cichlasoma Meeki & Lesão ocular e septicemia \\
\hline & 1 & Cichlasoma salvini & Lesão ocular e septicemia \\
\hline & 1 & Ciprinus carpio & Lesão de pele \\
\hline & 2 & Danio rerio & Lesão de pele \\
\hline & 1 & Misgurnus anguillicaudatus & Septicemia \\
\hline & 1 & Pangasius hypophthalmus & Septicemia \\
\hline & 1 & Pterophyllum scalare & Septicemia \\
\hline & 1 & Symphysodon discus & Lesão ocular e septicemia \\
\hline & 2 & Trichopodus leerii & Septicemia \\
\hline & 1 & Thayeria boehlkei & Septicemia \\
\hline & 1 & Tropheus moorii & Septicemia \\
\hline \multicolumn{4}{|l|}{ TOTAL } \\
\hline \multirow{4}{*}{ Aeromonas jandei } & 2 & Polypterus senegalus & Lesão de pele \\
\hline & 1 & Thayeria boehlkei & Septicemia \\
\hline & 1 & Trichogaster trichopterus & Septicemia \\
\hline & 2 & Trichopodus leerii & Septicemia \\
\hline TOTAL & 6 & & \\
\hline \multirow{8}{*}{ Citrobacter freundii } & 7 & Carassius auratus & Lesão ocular e septicemia \\
\hline & 1 & Cichlasoma Meeki & Lesão ocular e septicemia \\
\hline & 5 & Ciprinus carpio & Lesão de pele \\
\hline & 1 & Maylandia zebra & Septicemia \\
\hline & 2 & Symphysodon discus. & Lesão ocular e septicemia \\
\hline & 1 & Synodontis petricola & Septicemia \\
\hline & 1 & Scatophagus argus & Septicemia \\
\hline & 1 & Trichogaster lalius & Septicemia \\
\hline
\end{tabular}




\begin{tabular}{|c|c|c|c|}
\hline \multirow{7}{*}{ Shevanella putrefaciens } & 1 & Aequidens rivulatus & Lesão ocular e septicemia \\
\hline & 1 & Betta splendens & Septicemia \\
\hline & 12 & Carassius auratus & Lesão ocular e septicemia \\
\hline & 3 & Cichlasoma salvini & Lesão ocular e septicemia \\
\hline & 2 & Ciprinus carpio & Lesão de pele \\
\hline & 1 & Cyphotilapia frontosa & Septicemia \\
\hline & 1 & Demasoni pombo & Septicemia \\
\hline & 21 & TOTAL & \\
\hline \multirow{5}{*}{ Klebsiella pneumoniae } & 1 & Aequidens rivulatus & Lesão ocular e septicemia \\
\hline & 1 & Epalzeorhynchos bicolor & Lesão ocular e septicemia \\
\hline & 4 & Polypterus senegalus & Lesão de pele \\
\hline & 1 & Pterophyllum scalare & Septicemia \\
\hline & 4 & Symphysodon discus. & Lesão ocular e septicemia \\
\hline
\end{tabular}

TOTAL 11

\begin{tabular}{|l|l|l|l|}
\hline \multirow{5}{*}{ Vibrio albensis } & 7 & Carassius auratus & Lesão ocular e septicemia \\
\cline { 2 - 4 } & 1 & Cichlasoma salvini & Lesão ocular e septicemia \\
\cline { 2 - 4 } & 2 & Cyphotilapia frontosa & Septicemia \\
\cline { 2 - 4 } & 4 & Melanotaenia praecox & Septicemia \\
\cline { 2 - 4 } & 2 & Mealanotaenia trifasciata & Septicemia \\
\cline { 2 - 4 } & 1 & Synodontis petricola & Septicemia \\
\cline { 2 - 4 } & 2 & Symphysodon discus. & Lesão ocular e septicemia \\
\hline
\end{tabular}

TOTAL

Outras bactérias menos frequentes 


\begin{tabular}{|c|c|c|c|}
\hline Aeromonas enteropelogenes & 1 & Xiphophorus maculatus & Septiciemia \\
\hline Aeromonas icthiosmia & 1 & Carassius auratus & Lesão ocular e septicemia \\
\hline Acinetobacter baylyi & 1 & Cichlasoma salvini & Lesão ocular e septicemia \\
\hline Acinetobacter junii & 2 & Cichlasoma salvini & Lesão ocular e septicemia \\
\hline \multirow{2}{*}{ Citrobacter braakii } & 1 & Ciprinus carpio & Lesão de pele \\
\hline & 1 & Carassius auratus & Septicemia \\
\hline Citrobacter gillenii & 3 & Carassius auratus & Septicemia \\
\hline Edwardisella tarda & 1 & Ciprinus carpio & Lesão de pele e septicemia \\
\hline Enterobacter asburiae & 4 & Carassius auratus & Lesão ocular e septicemia \\
\hline \multirow{2}{*}{ Enterococcus hirae } & 1 & Carassius auratus & Septicemia \\
\hline & 1 & Symphysodon discus. & Septicemia \\
\hline \multirow{4}{*}{ Pseudomonas alcaligenes } & 1 & Danio rerio & Lesão de pele e septicemia \\
\hline & 1 & Cichlasoma salvini & Lesão ocular e septicemia \\
\hline & 1 & Polypterus senegalus & Lesão de pele \\
\hline & 1 & Xiphophorus maculatus & Septicemia \\
\hline \multirow{2}{*}{ Plesiomonas shigueloides } & 1 & Scatophagus argus & Septicemia \\
\hline & 2 & Polypterus senegalus & Lesão de pele \\
\hline \multirow[b]{2}{*}{ Vibrio vulnificus } & 1 & Astronotus ocellatus & Septicemia \\
\hline & 1 & Cyphotilapia frontosa & Lesão ocular e septicemia \\
\hline TOTAL & \multicolumn{3}{|r|}{ 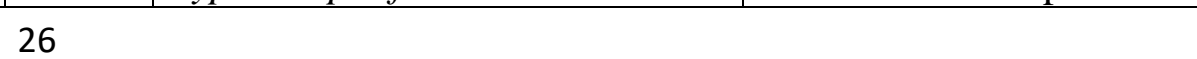 } \\
\hline GERAL & \multicolumn{3}{|l|}{295} \\
\hline
\end{tabular}

TOTAL GERAL 
Apêndice 9: Isolados bacterianos em amostras de peixes de água salgada

\begin{tabular}{|l|l|l|l|}
\hline Agente & Qtde & Espécie Acometida & Tipo de lesão \\
\hline Aeromonas veroni & 1 & Chaetodon vagabundus & Septicemia \\
\hline Acinetobacter baylyi & 1 & Chromis vanderbuilt & Lesão de pele e septicemia \\
\hline Acinetobacter baumanni & 1 & Chromis vanderbuilt & Lesão de pele e septicemia \\
\hline Plesiomonas shigueloides & 1 & Chromis viridis & Septicemia \\
\hline Kluyvera ascorbata & 1 & Chaetodon auriga & Septicemia \\
\hline Staphyloccocus epidermidis & 1 & Pseudanthias squamipinnis & Septicemia \\
\hline \multirow{5}{*}{ Shewaanella putrefasciens } & 1 & Chromis vanderbuilt & Septicemia \\
\cline { 2 - 4 } & 1 & Chaetodon vagabundus & Septicemia \\
\cline { 2 - 4 } & 1 & Pseudanthias squamipinnis & Septicemia \\
\cline { 2 - 4 } & 1 & Chaetodon auriga & Septicemia \\
\cline { 2 - 4 } & 1 & Heniochus acuminatus & Septicemia \\
\hline Stenotrophomonas maltophila & 1 & Chromis viridis & Septicemia \\
\hline Streptococcus oralis & 1 & Chromis vanderbuilt & Lesão de pele \\
\hline Vibrio algynoliticus & 1 & Heniochus acuminatus & Lesão de pele \\
\hline \multirow{2}{*}{ TOTAL } & 14 & & \\
\hline
\end{tabular}


Apêndice 10: PCR das amostras enviadas para virologia

\begin{tabular}{|c|c|c|c|c|c|}
\hline Amostra & $\begin{array}{l}\text { Espécie de peixe } \\
\text { ornamental }\end{array}$ & $\begin{array}{l}\text { CyHV-1 } \\
\text { e } \\
\text { CyHV-2 }\end{array}$ & CyHV-3 & LCDV & MV \\
\hline 247 & Poecilia reticulata & Negativo & Negativo & Negativo & Positivo \\
\hline 248 & Pygocentrus nattereri & Negativo & Negativo & Negativo & Positivo \\
\hline 249 & Pygocentrus nattereri & Negativo & Negativo & Negativo & Positivo \\
\hline 250 & Pygocentrus nattereri & Negativo & Negativo & Negativo & Positivo \\
\hline 251 & Pygocentrus nattereri & Negativo & Negativo & Negativo & Positivo \\
\hline 252 & Pygocentrus nattereri & Negativo & Negativo & Negativo & Positivo \\
\hline 253 & Pygocentrus nattereri & Negativo & Negativo & Negativo & Positivo \\
\hline 254 & Pygocentrus nattereri & Negativo & Negativo & Negativo & Positivo \\
\hline 255 & Pygocentrus nattereri & Negativo & Negativo & Negativo & Positivo \\
\hline 256 & Cyprinus carpio & Negativo & Negativo & Negativo & Positivo \\
\hline 257 & Cyprinus carpio & Negativo & Negativo & Negativo & Positivo \\
\hline 259 & Trichogaster leeri & Negativo & Negativo & Negativo & Positivo \\
\hline 260 & Trichogaster leeri & Negativo & Negativo & Negativo & Positivo \\
\hline 261 & Pomacanthus imperator & Negativo & Negativo & Positivo & Negativo \\
\hline 263 & Glossolepis incisus & Negativo & Negativo & Negativo & Negativo \\
\hline 264 & Monodactylus argentus & Negativo & Negativo & Negativo & Negativo \\
\hline 265 & Cyprinus carpio & Negativo & Negativo & Negativo & Negativo \\
\hline 266 & Cyprinus carpio & Negativo & Negativo & Negativo & Negativo \\
\hline 267 & Cyprinus carpio & Negativo & Negativo & Negativo & Negativo \\
\hline 268 & Trichogaster trichopterus & Negativo & Negativo & Negativo & Positivo \\
\hline 269 & Trichogaster trichopterus & Negativo & Negativo & Negativo & Positivo \\
\hline
\end{tabular}




\begin{tabular}{|c|c|c|c|c|c|}
\hline 270 & Trichogaster trichopterus & Negativo & Negativo & Negativo & Positivo \\
\hline 271 & Macropodus opercularis & Negativo & Negativo & Negativo & Negativo \\
\hline 272 & Macropodus opercularis & Negativo & Negativo & Negativo & Positivo \\
\hline 273 & Macropodus opercularis & Negativo & Negativo & Negativo & Positivo \\
\hline 274 & Carassius auratus & Negativo & Negativo & Negativo & Positivo \\
\hline 275 & Carassius auratus & Negativo & Negativo & Negativo & Positivo \\
\hline 276 & Carassius auratus & Negativo & Negativo & Negativo & Negativo \\
\hline 277 & Trichogaster trichopterus & Negativo & Negativo & Negativo & Negativo \\
\hline 278 & Trichogaster trichopterus & Negativo & Negativo & Negativo & Negativo \\
\hline 279 & Trichogaster trichopterus & Negativo & Negativo & Negativo & Positivo \\
\hline 280 & Trichogaster trichopterus & Negativo & Negativo & Negativo & Positivo \\
\hline 281 & Cyprinus carpio & Negativo & Negativo & Negativo & Negativo \\
\hline 282 & Serrasalmus gibbus & Negativo & Negativo & Negativo & Positivo \\
\hline 283 & Carassius auratus & Negativo & Negativo & Negativo & Negativo \\
\hline 284 & Pangasius hypophthalmus & Negativo & Negativo & Negativo & Negativo \\
\hline 285 & Pangasius hypophthalmus & Negativo & Negativo & Negativo & Positivo \\
\hline 286 & Pterophyllum scalare & Negativo & Negativo & Negativo & Negativo \\
\hline 287 & Pterophyllum scalare & Negativo & Negativo & Negativo & Negativo \\
\hline 288 & Moenkhausia costae & Negativo & Negativo & Negativo & Positivo \\
\hline 289 & Moenkhausia costae & Negativo & Negativo & Negativo & Negativo \\
\hline 290 & Moenkhausia costae & Negativo & Negativo & Negativo & Positivo \\
\hline 291 & Xiphophorus maculatus & Negativo & Negativo & Negativo & Positivo \\
\hline 292 & Brachdanio albolineatus & Negativo & Negativo & Negativo & Positivo \\
\hline 294 & \begin{tabular}{|l|} 
Misgurnos \\
anguillicaudatus
\end{tabular} & Negativo & Negativo & Negativo & Positivo \\
\hline 295 & Hypostomus plecostomus & Negativo & Negativo & Negativo & Positivo \\
\hline
\end{tabular}




\begin{tabular}{|c|l|l|l|l|l|}
296 & Trichogaster lalius & Negativo & Negativo & Negativo & Negativo \\
\hline 298 & Poecilia reticulata & Negativo & Negativo & Negativo & Positivo \\
\hline 299 & $\begin{array}{l}\text { Misgurnos } \\
\text { anguillicaudatus }\end{array}$ & Negativo & Negativo & Negativo & Positivo \\
\hline 300 & Araipama gigas & Negativo & Negativo & Negativo & Positivo \\
\hline 301 & Pterophyllum scalare & Negativo & Negativo & Negativo & Positivo \\
\hline 302 & Carassius auratus & Negativo & Negativo & Negativo & Positivo \\
\hline 303 & Hemiodopsis gracilis & Negativo & Negativo & Negativo & Positivo \\
\hline 304 & Moenkhausia costae & Negativo & Negativo & Negativo & Positivo \\
\hline 306 & Carassius auratus & Negativo & Negativo & Negativo & Negativo \\
\hline
\end{tabular}


Apêndice 11: Microscopia das lesões nodulares suspeitos de Lymphocystivirus

\begin{tabular}{|l|l|l|l|}
\hline Agente & Qtde & Espécie Acometida & Lesões nodulares \\
\hline \multirow{4}{*}{ Lymphocystis vírus } & 3 & Acanthurus coeruleus & Nas nadadeiras \\
\cline { 2 - 4 } & 2 & Acanthurus desjardini & Na pele \\
\cline { 2 - 4 } & 1 & Centropyge multispinis & Nas nadadeiras \\
\cline { 2 - 4 } & 7 & Chaetodon auriga & Nas nadadeiras \\
\hline & 5 & Chemon rostratus & Na nadadeira caudal \\
\cline { 2 - 4 } & 2 & Pomacanthus imperator & Na pele \\
\hline & 6 & Pomacanthus semicirculatus & Na pele e opérculo \\
\cline { 2 - 4 } & 2 & Zebrasoma flavens & Na boca e nadadeira \\
\hline
\end{tabular}


Apêndice 12: Microscopia dos animais de água doce positivos para Saprolegnia

\begin{tabular}{|c|c|l|c|}
\hline \multicolumn{5}{|c|}{ Agente } & Qtde & Espécie Acometida & Lesão algodonosa \\
\hline \multirow{4}{*}{ Saprolegnia sp } & 10 & Corydoras elegans & Nadadeiras \\
\cline { 2 - 4 } & 12 & Baryancistrus spp & Pele \\
\cline { 2 - 4 } & 5 & Helostoma temminckii & Pele \\
\cline { 2 - 4 } & 6 & Mikrogeophagus ramirezi & Pele \\
\cline { 2 - 4 } & 8 & Trichogaster lalius & Pele \\
\cline { 2 - 4 } & 4 & Trichogaster trichopterus & Pele \\
\hline \multirow{4}{*}{ Total geral } & 45 & \\
\hline
\end{tabular}


Apêndice 13: Microscopia dos animais de água doce positivos para doenças parasitárias

\begin{tabular}{|c|c|c|c|}
\hline Agente & Qtde & Espécie Acometida & Órgão afetado \\
\hline \multirow{21}{*}{$\begin{array}{l}\text { Ichthyophthirius } \\
\text { multifilis }\end{array}$} & 3 & Aequidens rivulatus & Pele \\
\hline & 3 & Amphilophus trimaculatus & Pele \\
\hline & 2 & Astronatus ocellatus & Pele \\
\hline & 1 & Aulonocara hansbaenchi & Pele \\
\hline & 2 & Carnegiella strigata & Pele \\
\hline & 1 & Chromobotia maracanthus & Pele \\
\hline & 1 & Cichlasoma salvini & Pele \\
\hline & 3 & Cichlasoma severum & Pele \\
\hline & 1 & Cichlasoma spp & Pele \\
\hline & 1 & Corydoras elegans & Pele \\
\hline & 4 & Gymnocorybus ternetzi & Pele \\
\hline & 1 & Heigrammus ulrey & Pele \\
\hline & 1 & Helostoma temminckii & Pele \\
\hline & 1 & Hemichromis bimaculatus & Pele \\
\hline & 1 & Herus severus & Pele \\
\hline & 3 & Hypancistrus inspector & Pele \\
\hline & 1 & Hypancistrus plecostomu & Pele \\
\hline & 1 & Hyphessobrycon anisitsi & Pele \\
\hline & 1 & Hyphessobrycon columbianus & Pele \\
\hline & 2 & $\begin{array}{l}\text { Hyphessobrycon } \\
\text { herbertaxelrodi }\end{array}$ & Pele \\
\hline & 1 & Hyphessobrycon socolofi & Pele \\
\hline
\end{tabular}




\begin{tabular}{|c|c|c|c|}
\hline & 1 & Hypselecara coryphaenoides & Pele \\
\hline & 1 & Iriatherina $\mathrm{spp}$ & Pele \\
\hline & 1 & Labeo chrysophekadion & Pele \\
\hline & 1 & Macropodus operularis & Pele \\
\hline & 1 & Melanotaenia gold & Pele \\
\hline & 1 & Misgumus anguillicaudatus & Pele \\
\hline & 1 & Moenkhausia sanctaefilome & Pele \\
\hline & 2 & Myloplus rubripinnis & Pele \\
\hline & 1 & Nandopsis octofascaitum & Pele \\
\hline & 1 & Paracheirodon axelrodi & Pele \\
\hline & 2 & Paracheirodon innesi & Pele \\
\hline & 1 & Piaractus mesopotamicus & Pele \\
\hline & 2 & Poecillia latipinna & Pele \\
\hline & 2 & Poecillia reticulata & Pele \\
\hline & 1 & Pristella maxillaris & Pele \\
\hline & 1 & Puntigrus tetrazona & Pele \\
\hline & 6 & Symphodon discus & Pele \\
\hline & 1 & Tanichthys albonubes & Pele \\
\hline & 2 & Trichopodus trichopterus & Pele \\
\hline & 1 & Tricogaster microlepis & Pele \\
\hline & 1 & Uaru amphiacantoides & Pele \\
\hline & 4 & Xiphophorus helleri & Pele \\
\hline & 5 & Xiphophorus maculatus & Pele \\
\hline TOTAL & 75 & $31 \%$ & \\
\hline Chillodonolla sn & 2 & Etroplus maculatus & Brânquias \\
\hline Cmanounetas & 2 & Hyphessobrycon eques & Brânquias \\
\hline
\end{tabular}




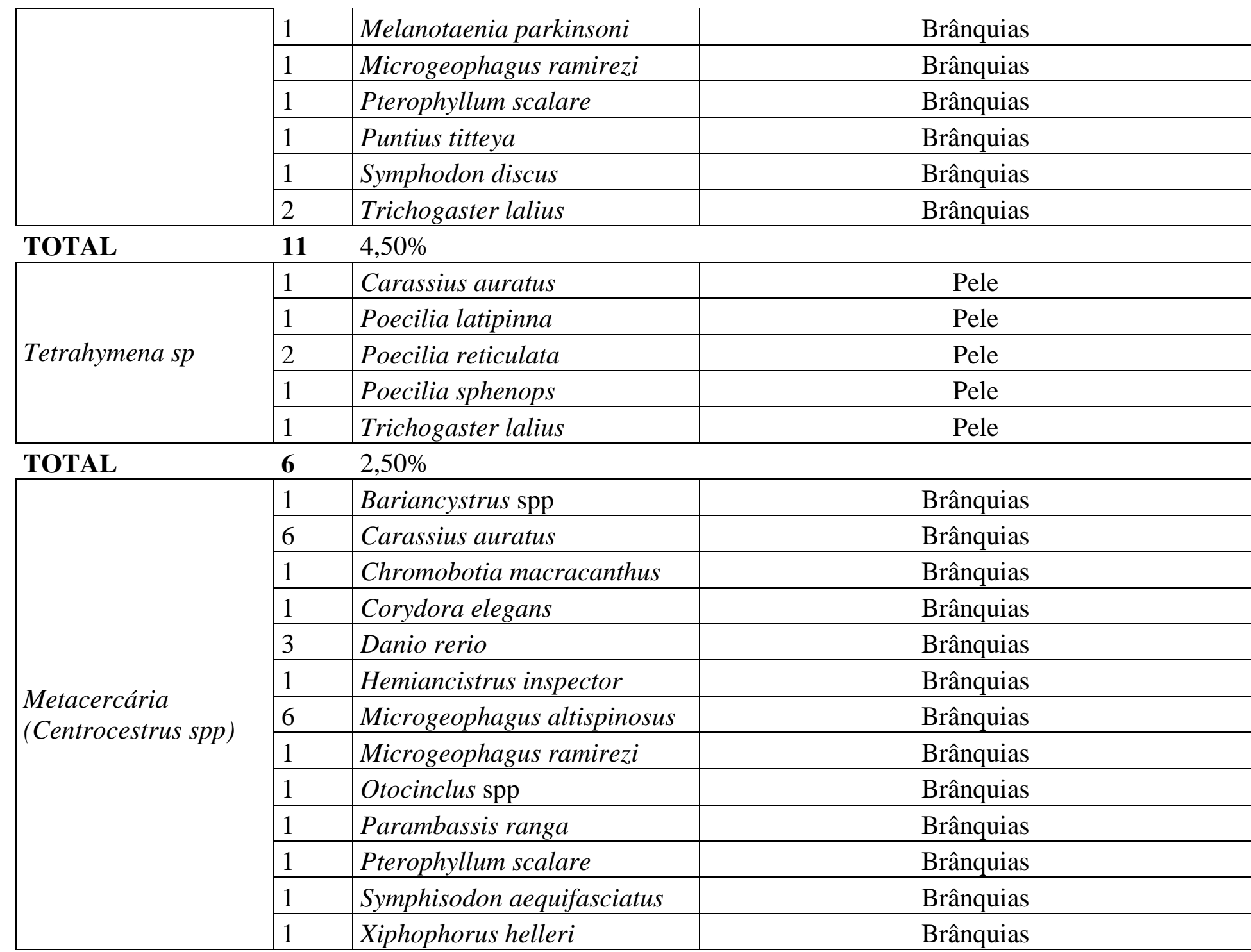




\begin{tabular}{|c|c|c|c|}
\hline & 15 & Xiphophorus maculatus & Brânquias \\
\hline TOTAL & 40 & $16,50 \%$ & \\
\hline \multirow{2}{*}{ Piscinoodinium $s p$} & 3 & Betta splendens & Pele \\
\hline & 2 & Carassius auratus & Pele \\
\hline TOTAL & 5 & $2 \%$ & \\
\hline \multirow{17}{*}{ Epistylis sp } & 2 & Carassius auratus & Pele \\
\hline & 2 & Cichlasoma octoofasciatum & Pele \\
\hline & 1 & Cichlassoma salvini & Pele \\
\hline & 2 & Cyprinus carpio & Pele \\
\hline & 1 & Hemichromis bimaculatus & Pele \\
\hline & 1 & Hypostomus cochliodon & Pele \\
\hline & 2 & Microgeophagus ramirezi & Pele \\
\hline & 1 & Microgeophagus altispinosus & Pele \\
\hline & 1 & Poecilia reticulata & Pele \\
\hline & 1 & Poecilia sphenops & Pele \\
\hline & 1 & Pseudacanthicus leopardus & Pele \\
\hline & 1 & Pterophyllum scalare & Pele \\
\hline & 3 & Trichogaster lalius & Pele \\
\hline & 1 & Trichopodus leerii & Pele \\
\hline & 1 & Trichopodus trichopterus & Pele \\
\hline & 2 & Tricogaster microlepsis & Pele \\
\hline & 1 & Xenotilapia spp & Pele \\
\hline TOTAL & 24 & $10 \%$ & \\
\hline \multirow{3}{*}{ Nematóide } & 1 & Carassius auratus & Intestino \\
\hline & 1 & Corydoras elegans & Intestino \\
\hline & 1 & Microgeophagus altispinosus & Intestino \\
\hline
\end{tabular}




\begin{tabular}{|c|c|c|c|}
\hline & 1 & Osteoglossum bicirrh & Intestino \\
\hline & 1 & Poecilia reticulata & Intestino \\
\hline & 4 & Pterophyllum scalare & Intestino \\
\hline & 1 & Pygocentrus nattereri & Intestino \\
\hline & 3 & Symphodon discus & Intestino \\
\hline & 1 & Trichopodus leerii & Intestino \\
\hline TOTAL & 14 & $6 \%$ & \\
\hline \multirow{6}{*}{ Lerneae sp } & 1 & Carassius auratus & Pele \\
\hline & 2 & Gymnocorymbus ternetzi & Pele \\
\hline & 1 & Poecilia reticulata & Pele \\
\hline & 1 & Tanichthys albonubes & Pele \\
\hline & 3 & Xiphophorus helleri & Pele \\
\hline & 2 & Xiphophorus maculatus & Pele \\
\hline TOTAL & 10 & $4 \%$ & \\
\hline Argulus sp & 2 & Ciprinus carpio & Pele \\
\hline TOTAL & 2 & $1 \%$ & \\
\hline \multirow{4}{*}{ Trichodina $s p$} & 2 & Betta splenders & Pele \\
\hline & 1 & Melanotaenia parkinson & Pele \\
\hline & 1 & Monodactylus argenteus & Pele \\
\hline & 1 & Poecilia reticulata & Pele \\
\hline TOTAL & 5 & $2 \%$ & \\
\hline \multirow{4}{*}{ Ichthyobodo sp } & 1 & Baryancistrus spp & Pele e Brânquias \\
\hline & 1 & Cichlasoma maculicauda & Pele e Brânquias \\
\hline & 1 & Heliostoma temminki & Pele e Brânquias \\
\hline & 1 & Pterophyllum scalare & Pele e Brânquias \\
\hline
\end{tabular}




\begin{tabular}{|c|c|c|c|}
\hline TOTAL & 4 & $16,50 \%$ & \\
\hline & 1 & Arapaima gigas & Pele e Brânquias \\
\hline & 12 & Carassius auratus & Pele e Brânquias \\
\hline & 1 & Cichlasoma severum & Pele e Brânquias \\
\hline & 5 & Cyprinus carpio & Pele e Brânquias \\
\hline & 1 & Etroplus maculatus & Pele e Brânquias \\
\hline Monoô̂nea & 1 & Gymnocorymbus ternetzi & Pele e Brânquias \\
\hline ivonogenea & 1 & Nematobrycon palmeri & Pele e Brânquias \\
\hline & 2 & Poecilia reticulata & Pele e Brânquias \\
\hline & 1 & Pseudotropheus demasoni & Pele e Brânquias \\
\hline & 7 & Pterophyllum scalare & Pele e Brânquias \\
\hline & 3 & Symphodon discus & Pele e Brânquias \\
\hline & 3 & Trichopodus trichopterus & Pele e Brânquias \\
\hline TOTAL & 38 & $15,50 \%$ & \\
\hline & 1 & Amphilophus trimaculatus & Pele \\
\hline Spironucleus/ & 6 & Pterophyllum scalare & Intestino \\
\hline Hexamita & 1 & Symphodon discus & Intestino \\
\hline & 1 & Symphisodon aequifasciatus & Intestino \\
\hline TOTAL & 9 & $3,50 \%$ & \\
\hline TOTAL GERAL & 243 & & \\
\hline
\end{tabular}


Apêndice 14: Microscopia dos peixes ornamentais de água salgada positivos para doenças parasitárias

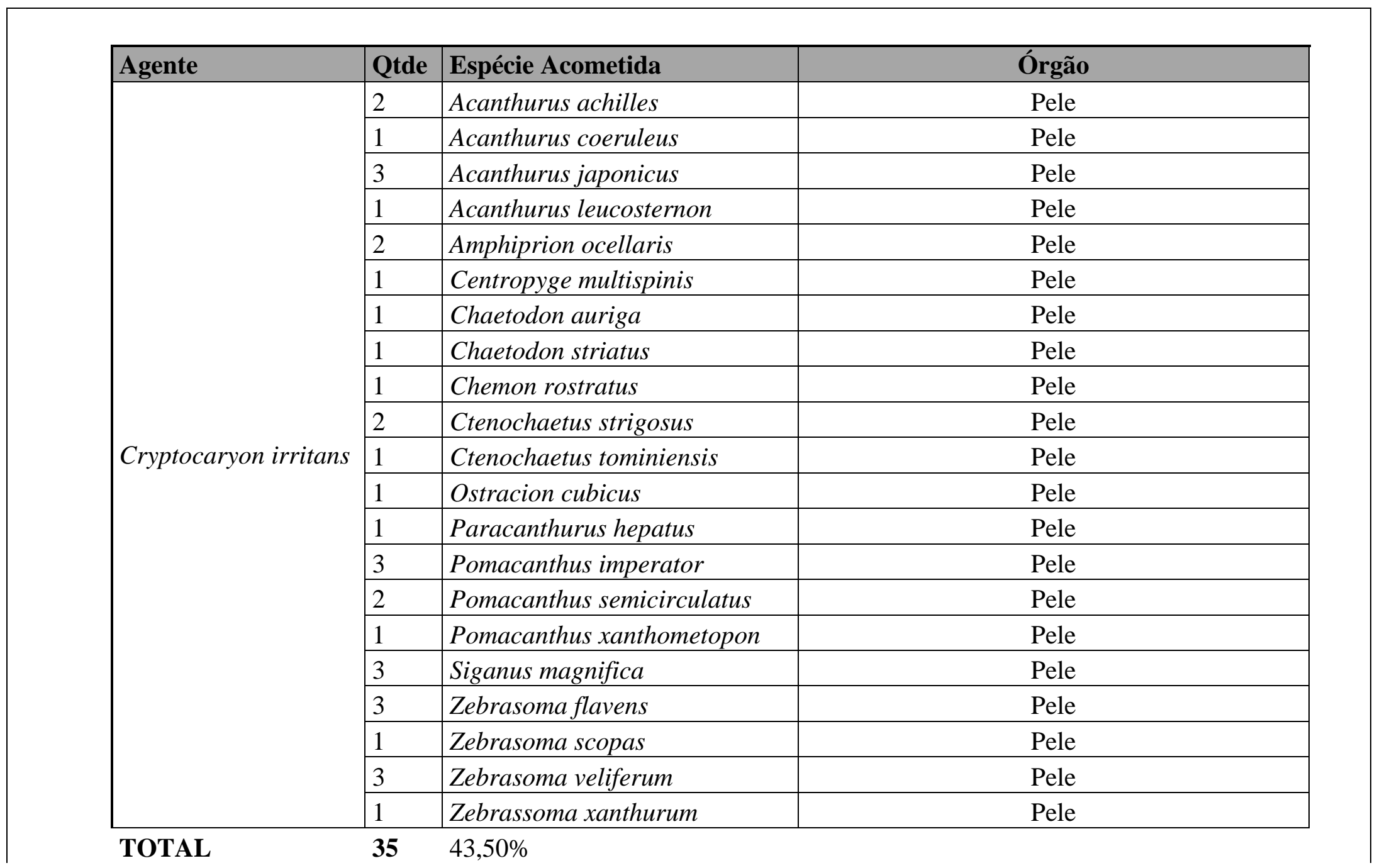




\begin{tabular}{|c|c|c|c|}
\hline \multirow{14}{*}{ Uronema sp } & 1 & Centropyge multispinis & Pele \\
\hline & 1 & Chaetodon auriga & Pele \\
\hline & 1 & Chaetodon vagabundus & Pele \\
\hline & 4 & Chromis viridis & Pele \\
\hline & 1 & Chrysiptera spp & Pele \\
\hline & 1 & Ctenochaetus strigosus & Pele \\
\hline & 1 & Heniochus spp & Pele \\
\hline & 2 & Labroides dimidiatus & Pele \\
\hline & 1 & Neopomacentrus azysron & Pele \\
\hline & 1 & Pomacathus xanthometopon & Pele \\
\hline & 1 & Pseudoanthias pictilis & Pele \\
\hline & 2 & Pseudoanthias squamipinis & Pele \\
\hline & 1 & Pterapogon kauderni & Pele \\
\hline & 1 & Siganus magnifica & Pele \\
\hline TOTAL & 19 & $23,50 \%$ & \\
\hline \multirow{11}{*}{ Monogênea II } & 1 & Acanthurus pyroferus & Pele \\
\hline & 1 & Amphiprion ocellaris & Pele \\
\hline & 1 & Balistoides conspicillum & Pele \\
\hline & 1 & Centropyge bispinosus & Pele \\
\hline & 1 & Centropyge loricula & Pele \\
\hline & 2 & Centropyge multispinis & Pele \\
\hline & 1 & Cryptocentrus leptocephalus & Pele \\
\hline & 1 & Holacanthus ciliaris & Pele \\
\hline & 1 & Macropharyngodon meleagris & Pele \\
\hline & 1 & Neopomacentrus azysron & Pele \\
\hline & 1 & Pomacanthus imperator & Pele \\
\hline
\end{tabular}




\begin{tabular}{l|l|l|l|}
\hline \multirow{4}{*}{} & 1 & Pomacanthus maculosus & Pele \\
\cline { 2 - 4 } & 1 & Pomacanthus semicirculatus & Pele \\
\cline { 2 - 4 } & 1 & Pomacathus xanthometopon & Pele \\
\cline { 2 - 4 } & 1 & Zebrasoma flavens & Pele \\
\hline \multirow{2}{*}{ TOTAL } & $\mathbf{1 6}$ & $19,50 \%$ & Pele e Brânquias \\
\hline Broklynella sp & 10 & Amphiprion ocellaris & Pele e Brânquias \\
\cline { 2 - 4 } & 1 & Centropyge multispinis & \\
TOTAL & $\mathbf{1 1}$ & $13,50 \%$ & \\
Total Geral & 81 & &
\end{tabular}




\section{Capítulo 4}

A aplicação do Sistema APPCC em comércio atacadista e peixes ornamentais 


\subsection{INTRODUÇÃO}

O sistema de Análise de Perigos e Pontos Críticos de Controle - APPCC, conhecido internacionalmente por Hazard Analysis and Critical Control Point (HACCP), originou-se na indústria química e se estendeu para a indústria de alimentos (HULEBAK; SCHLOSSER, 2002). Desde 1998, o Brasil mostrou-se preocupado com assuntos relacionados a segurança alimentar e publicou uma série de documentos relacionados ao APPCC, Boas Práticas e Procedimentos Operacionais Padronizados. Inicialmente, antes da implementação do plano APPCC é necessário a implementação de Boas Práticas capazes de garantir um padrão de conduta e de prevenir e controlar perigos relevantes dentro de uma unidade produtora e/ou comercializadora de qualquer tipo de produto, não sendo instrumentos restritos ao setor alimentício.

O sistema APPCC vem sendo adotado em várias partes do mundo, não só para garantir a segurança de processos e produtos, mas também para reduzir custos e aumentar a lucratividade. Trata-se de um sistema de autocontrole de caráter preventivo, lógico, científico e focado em processos. Por tais características trouxe novo paradigma para os sistemas de controle e gestão de qualidade. Estabelecendo controle transparente e confiável, constitui-se na ferramenta de gestão mais eficaz na obtenção de produtos alimentícios seguros para a saúde do consumidor (CODEX ALIMENTARIUS COMMISSION, 2003).

O delineamento do sistema APPCC não se restringe apenas ao setor de alimentos; os benefícios da adoção de seus princípios e lógica, podem ser aplicados a qualquer sistema produtivo. O sistema APPCC identifica perigos capazes de comprometer os produtos e impõe ações corretivas perante qualquer alteração, durante o processamento. Aproveitando-se de suas características e vantagens, decidiu-se de forma pioneira no Brasil, pela sua utilização no processo de comercialização de peixes ornamentais.

O sistema APPCC não é um programa independente, mas sim parte de um extenso sistema de procedimentos de controle para garantir a segurança do produto final. Para funcionar correta e eficientemente, deve ser acompanhado de programas de pré-requisitos apresentados no Capítulo 2, os quais proporcionarão as condições operacionais e ambientais básicas para a execução de procedimentos corretos e a produção de produtos com qualidade assegurada. Permitem identificar dúvidas sobre a segurança e as condições sanitárias, possibilitando ajustes, correções e melhorias para que não ocorram desvios quando da aplicação e execução do plano APPCC. Após fazer todos os ajustes de modo que os pré-requisitos estejam conformes, é possível se pensar no fluxograma do processo produtivo e iniciar a aplicação dos sete princípios que compõem o sistema APPCC (FDA, 2011). Lembrando que um plano 
APPCC é processo-produto específico em unidades produtoras de algum bem, seja ele produto ou serviço. Neste caso, a comercialização de peixes ornamentais dentro de um estabelecimento atacadista, que abrange desde o recebimento até a expedição ao comércio varejista.

Conforme já discutido no Capítulo 03, o princípio 1 do plano APPCC é a identificação dos perigos de natureza biológica, pelos quais os peixes ornamentais estão susceptíveis e a identificação de medidas preventivas para o seu controle, buscando eliminá-los, preveni-los ou reduzi-los a níveis aceitáveis.

O princípio 2 do plano APPCC é a identificação dos Pontos Críticos de Controle (PCC). Os PCC são pontos caracterizados como realmente críticos à segurança dos peixes ornamentais. As ações e esforços de controle dos PCC devem ser, portanto, concentrados. O número de PCC deve ser restrito ao mínimo e indispensável. Mais de um perigo pode ser controlado em um mesmo PCC e mais que um PCC pode ser necessário para controlar um único perigo.

O princípio 3 do plano APPCC é o estabelecimento de limites críticos par cada PCC. O limite crítico é um valor máximo e/ou mínimo de parâmetros biológicos que assegure o controle do perigo. São valores que podem ser obtidos a partir de guias e padrões de legislações, literatura, experiência prática, levantamento prévio de dados, experimentos laboratoriais e outras fontes.

O princípio 4 do plano APPCC é o estabelecimento de procedimentos de monitoramento. O monitoramento é uma sequencia de observações para avaliar se um determinado perigo está sob controle e para produzir um registro fiel para uso futuro na verificação. A escolha da pessoa responsável pelo monitoramento de cada PCC é muito importante e dependerá do número de PCC e de medidas preventivas, bem como da complexidade do monitoramento. $\mathrm{O}$ monitoramento contínuo é preferível, mas quando não for possível será necessário estabelecer uma frequência de controle para cada PCC. Observação visual e testes microbiológicos são exemplos de tipos de monitoramento. Testes microbiológicos não devem ser utilizados no monitoramento do PCC, pois fornecem resultados demorados.

O princípio 5 do plano APPCC é o estabelecimento de ações corretivas. As ações corretivas devem sempre ser aplicadas quando ocorrerem desvios dos limites críticos estabelecidos identificados durante o monitoramento. As ações corretivas devem ser registradas e, dependendo da frequência com que ocorrem os problemas, pode haver necessidade de aumento na frequência dos controles dos PCC ou até mesmo da modificação do processo. Este princípio do Plano APPCC pode ser aplicado nos programas de "pré-requisitos", como forma de correção de falhas encontradas nos mesmos. 
O princípio 6 do plano APPCC é o estabelecimento de procedimentos de verificação. As diretrizes do Codex definem verificação como "a aplicação de métodos, procedimentos, testes e outras avaliações, além do monitoramento, para determinar o correto cumprimento do plano. Métodos de auditoria, procedimentos e testes, inclusive de amostras aleatórias e análises, podem ser usadas para determinar se o sistema APPCC está funcionando corretamente.

E por fim, o princípio 7 do plano APPCC tem por finalidade estabelecer um sistema de registro de todos os controles. São provas por escrito ou eletrônicas, que documentam um ato ou fato. São essenciais para revisar a adequação do plano APPCC e a sua adesão ao sistema APPCC. Um registro mostra o histórico do processo, o monitoramento, os desvios e as ações corretivas aplicadas ao PCC identificado. É imprescindível que o estabelecimento mantenha registros completos, atualizados, corretamente arquivados e precisos.

Além de melhorar a qualidade do produto, a aplicação do sistema APPCC pode oferecer outras vantagens significativas, como facilitar as auditorias oficiais, por parte das autoridades de regulamentação e promover o comércio internacional ao aumentar a confiança na inocuidade do produto (CODEX ALIMENTARIUS COMMISSION, 2003).

O aumento na translocação e distribuição de animais aquáticos ornamentais faz com que haja aumento do risco de introdução de patógenos inespecíficos a partir de diferentes elos da cadeia. Frente a esta situação vivenciada pelo setor de organismos aquáticos ornamentais, acredita-se que a implementação de um sistema de autocontrole sanitário no comércio de peixes ornamentais com base na metodologia do sistema APPCC permita identificar os Pontos Críticos de Controle (PCC) na cadeia produtiva, promovendo um delineamento processual seguro para garantir sanidade e viabilidade econômica.

A aplicação dessas práticas produz dois significativos resultados positivos. O primeiro é o aumento da qualidade do produto em todas as etapas do processo, e o segundo é a geração de dados e informações técnicas que podem ser amplamente divulgadas em periódicos científicos, jornais, programas de televisão, além de ajudar os programas governamentais em prol do setor (FOSSA et al., 2009).

\subsection{MATERIAL E MÉTODOS}

\subsubsection{Determinação dos Pontos Críticos de Controle - PCC (Princípio 2)}

Os pontos críticos de controle (PCC) foram determinados através da aplicação da "árvore decisória" (Apêndice 15) sequencialmente a cada etapa do processo identificada no fluxograma (Apêndice 16), nas quais podem ser aplicadas medidas preventivas de controle com o objetivo de eliminar, prevenir ou reduzir a ocorrência dos perigos. Quando os perigos 
forem controlados pelo Programa de Pré-Requisitos em determinada etapa do processo de maneira efetiva, esta etapa é conhecida como Ponto de Controle (PC).

PS: A árvore decisória foi adaptada do Codex Alimentarius para a realidade no comércio atacadista de peixes ornamentais, e aplicada de maneira geral aos perigos biológicos (CODEX ALIMENTARIUS COMMISSION, 2003; OATA, 2006).

\subsubsection{Estabelecimento Limites Críticos de Controle (Princípio 3)}

Foram estabelecidos limites críticos para cada PCC, com base no conhecimento técnico e experiência acumulada pelo autor. Como estabelecer limites críticos nem sempre é simples, principalmente em casos subjetivos, foram estabelecidas especificações claras do que é considerado aceitável e inaceitável em cada etapa considerada um PCC. Em outros casos os limites podem ter base científica e os parâmetros a medir permitirão demonstrar que os PCC estão sob controle.

\subsubsection{Estabelecimento procedimentos de Monitoramento (Princípio 4)}

O monitoramento permite detectar situações fora dos limites estabelecidos e verificar se os PCC estão sob controle. Nessa fase ficou definido o quê, quem, como e quando monitorar os PCC.

\subsubsection{Estabelecimento de Ações Corretivas (Princípio 5)}

Foi elaborado um plano de Ações Corretivas para cada PCC para eventuais desvios dos limites críticos pré-estabelecidos. As ações corretivas devem garantir que:

- a ação de correção seja imediata;

- exista um responsável pré-determinado para executar a ação de correção, registrando esse procedimento em formulário próprio;

- seja previamente determinado o quê deve ser feito com o produto em situação de desvio do limite crítico;

- seja identificada a causa do desvio para que se evite novas ocorrências;

- exista um responsável técnico capacitado para a tomada de decisões e monitoramento.

\subsubsection{Estabelecimento de Procedimentos de Verificação (Princípio 6)}

Este passo deve assegurar que os PCC, os limites críticos, o monitoramento e as ações corretivas são apropriadas e que estão sendo executadas corretamente.

\subsubsection{Estabelecimento Registro de Dados e Documentação (Princípio 7)}


Para que o funcionamento seja eficiente e efetivo deve ser estabelecido um sistema para registro e documentação de todos os dados gerados com a utilização do plano APPCC, seja ele cartográfico ou eletrônico.

\subsection{RESULTADOS E DISCUSSÃO}

A partir de agora discorreremos sobre: 1) os PCC para o controle dos perigos de natureza biológica; 2) os limites críticos para os perigos biológicos em cada PCC; 3) como deve ser o monitoramento dos perigos biológicos em cada PCC; 4) como devem ser ações corretivas quando o PCC estiver fora de controle; 5) como devem ser os procedimentos de verificação em cada PCC. O resumo do que será discutido adiante está no quadro 2. 
Quadro 12: Resumo do plano APPCC

\begin{tabular}{|c|c|c|c|c|c|c|c|}
\hline PCC & Etapa & Perigo biológico & $\begin{array}{c}\text { Medidas Preventivas/de } \\
\text { Controle }\end{array}$ & Limite crítico & Monitoramento & Ação corretiva & Verificação \\
\hline PCC1 & Recebimento & $\begin{array}{l}\text { Bactérias, Vírus, } \\
\text { Fungos e Parasitas } \\
\text { que causam lesões } \\
\text { características já } \\
\text { mencionados no } \\
\text { Capítulo } 03 \text { da } \\
\text { presente tese. }\end{array}$ & $\begin{array}{l}\text { Inspeção visual a procura } \\
\text { de lesões características } \\
\text { às causadas pelos } \\
\text { patógenos ou presença de } \\
\text { ectoparasitas. }\end{array}$ & $\begin{array}{l}\text { Aceitável e PCC está } \\
\text { sob controle: Animais } \\
\text { saudáveis e sem lesões } \\
\text { aparentes. } \\
\text { Inaceitável e PCC está } \\
\text { fora de controle: } \\
\text { Animais com lesões } \\
\text { sugerindo infecção ou } \\
\text { infestação. }\end{array}$ & $\begin{array}{l}\text { O que? Todo } \\
\text { recebimento de novos } \\
\text { animais. Como? } \\
\text { Através de inspeções } \\
\text { visuais a procura de } \\
\text { lesões. Quando? } \\
\text { Sempre que um novo } \\
\text { lote de animais chegar } \\
\text { no estabelecimento. }\end{array}$ & $\begin{array}{l}\text { Recusar animais } \\
\text { com sinais } \\
\text { clínicos ou } \\
\text { patógenos } \\
\text { visíveis a olho nu } \\
\text { e advertir o } \\
\text { fornecedor sobre } \\
\text { o ocorrido. }\end{array}$ & $\begin{array}{l}\text { I) Envio de amostras } \\
\text { para diagnóstico; II) } \\
\text { Aplicação de } \\
\text { questionário para } \\
\text { avaliação do } \\
\text { conhecimento dos } \\
\text { responsáveis no } \\
\text { recebimento; III) } \\
\text { Auditoria do correto } \\
\text { preenchimento de } \\
\text { planilhas. }\end{array}$ \\
\hline $\mathrm{PCC} 2$ & Aclimatação & $\begin{array}{l}\text { Ectoparasitas } \\
\text { susceptíveis às } \\
\text { medidas } \\
\text { terapêuticas } \\
\text { mencionadas no } \\
\text { Capítulo } 03 \text { da } \\
\text { presente tese. }\end{array}$ & $\begin{array}{l}\text { Tratamento preventivo } \\
\text { com agentes terapêuticos } \\
\text { antes de entrar no sistema } \\
\text { no momento da } \\
\text { aclimatação. }\end{array}$ & $\begin{array}{l}\text { Aceitável e PCC está } \\
\text { sob controle: } \\
\text { Tratamento preventivo é } \\
\text { empregado } \\
\text { corretamente. } \\
\text { Inaceitável e PCC fora } \\
\text { de controle: Tratamento } \\
\text { preventivo não é } \\
\text { empregado } \\
\text { corretamente. }\end{array}$ & $\begin{array}{l}\text { O que? Procedimentos } \\
\text { de tratamento } \\
\text { preventivo. Como? } \\
\text { Verificar queda de } \\
\text { parasitas. Quando? } \\
\text { Sempre que houver um } \\
\text { novo lote de animais } \\
\text { para aclimatar. }\end{array}$ & $\begin{array}{l}\text { Seguir as } \\
\text { recomendações } \\
\text { imputadas para } \\
\text { tratamento } \\
\text { preventivo } \\
\text { corretamente e se } \\
\text { for o caso realizar } \\
\text { novos } \\
\text { treinamentos com } \\
\text { os responsáveis } \\
\text { por aclimatar. }\end{array}$ & $\begin{array}{l}\text { I) Aplicação de } \\
\text { questionário para avaliar } \\
\text { o conhecimento dos } \\
\text { responsáveis pela } \\
\text { aclimatação com relação } \\
\text { aos ectoparasitas; II) } \\
\text { Auditoria mensal para } \\
\text { verificação do } \\
\text { procedimento de } \\
\text { aclimatação com relação } \\
\text { a aplicação do } \\
\text { tratamento preventivo. }\end{array}$ \\
\hline PCC3 & Armazenamento & $\begin{array}{l}\text { Bactérias, Vírus, } \\
\text { Fungos e Parasitas } \\
\text { que podem não ter } \\
\text { sido eliminados nas } \\
\text { etapas anteriores e } \\
\text { já mencionados no } \\
\text { Capítulo 03. }\end{array}$ & $\begin{array}{l}\text { Tratamento da água de } \\
\text { recirculação através da } \\
\text { ozonição da água e filtro } \\
\text { ultravioleta ou tratamento } \\
\text { com agentes terapêuticos } \\
\text { em caso de diagnóstico de } \\
\text { doença. }\end{array}$ & $\begin{array}{l}\text { Aceitável e PCC está } \\
\text { sob controle: } \\
\text { Tratamento da água de } \\
\text { recirculação é realizado. } \\
\text { Inaceitável e PCC está } \\
\text { fora de controle: } \\
\text { Tratamento da água não } \\
\text { está sendo realizado. }\end{array}$ & $\begin{array}{l}\text { O que? A Saúde dos } \\
\text { animais e o correto } \\
\text { funcionamento dos } \\
\text { equipamentos para } \\
\text { controle de patógenos. } \\
\text { Como? Inspeção } \\
\text { visual dos animais e } \\
\text { inspeção dos } \\
\text { equipamentos. } \\
\text { Quando? Diariamente. }\end{array}$ & $\begin{array}{l}\text { Investigar a causa } \\
\text { do porque } \\
\text { ocorreu as falhas } \\
\text { no PCC nessa } \\
\text { etapa e após isso } \\
\text { corrigir as falhas } \\
\text { sejam elas } \\
\text { humanas ou } \\
\text { técnicas. }\end{array}$ & $\begin{array}{l}\text { I) Análise } \\
\text { microbiológica da água; } \\
\text { II) Teste da concentração } \\
\text { de gás ozônio na água; } \\
\text { III) Teste de matéria } \\
\text { orgânica na água. }\end{array}$ \\
\hline
\end{tabular}




\subsubsection{Pontos Críticos de Controle (Princípio 2)}

Após a utilização da árvore de decisão (Apêndice 15) foram determinados três PCC e um ponto de controle (PC) representado no diagrama de fluxo a seguir (figura 37). A explicação detalhada de cada etapa que possui PCC, PC e que Não é PCC será discutido a seguir para melhor entendimento do leitor.

Figura 37: Diagrama de fluxo com a representação dos PCC, PC e Não PCC após a utilização da árvore de decisão.

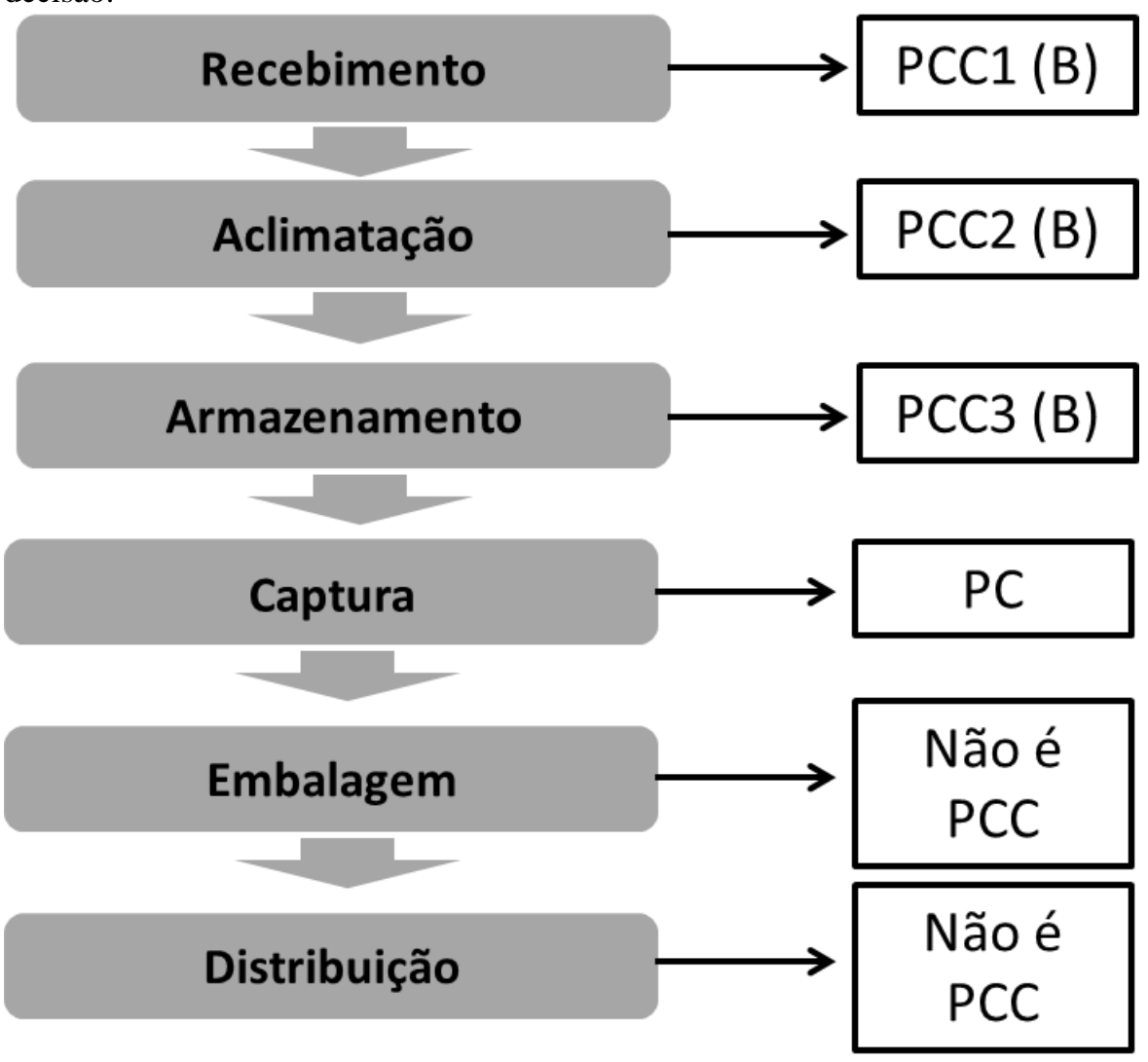

Fonte: Cardoso, 2017

\subsubsection{Recebimento}

$\mathrm{Na}$ etapa de recebimento dos peixes ornamentais foi determinado o primeiro ponto crítico de controle [PCC1] (figura 38) dos perigos de natureza biológica. As perguntas utilizadas na árvore decisória estão no final desse item (quadro 03) para o melhor entendimento do leitor de como chegamos a este resultado.

Figura 38: PCC 1 na etapa de recebimento dos peixes ornamentais 
A principal medida preventiva na etapa de recebimento para que haja redução e/ou eliminação dos perigos de natureza biológica se dá na inspeção visual de determinado agente (que podem ser visualizados a olho nu ou através das lesões que podem causar). Porém, para que essa medida preventiva seja efetiva é necessário que o responsável por executar a inspeção visual seja altamente treinado com relação aos tipos de lesões que determinados agentes podem causar.

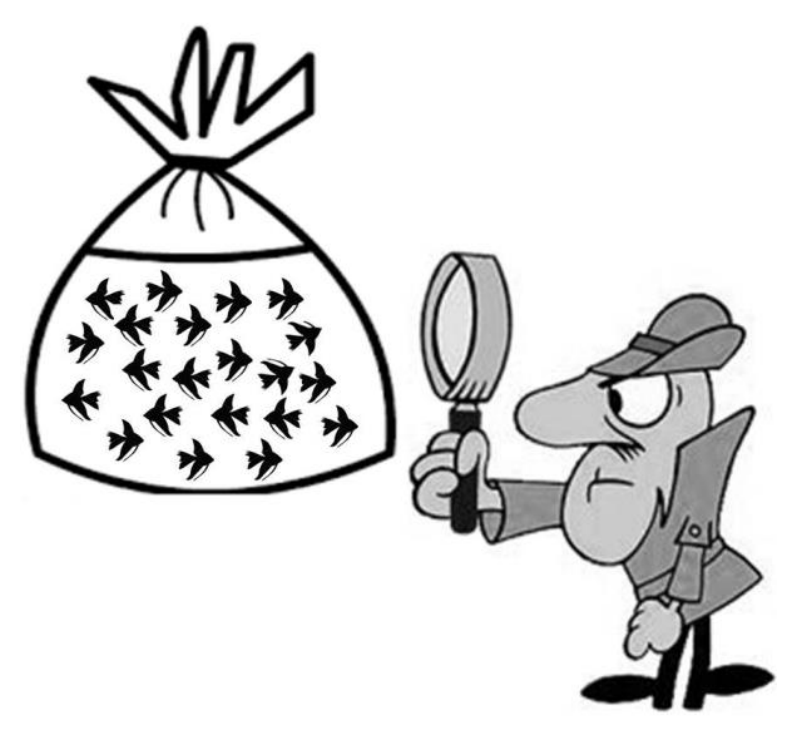

Infecções bacterianas causadas por Aeromonas e Vibrio spp podem ocasionar sinais clínicos de erosões na pele, opacidade de córnea e corrosão da nadadeira(HEWIARACHCHI et al., 1994; PARKER; SHAW, 2011; GRIM et al., 2013). Infecção viral causada pelo agente Lymphocystivirus, infecção fúngica causada por Saprolegnia spp e algumas infecções parasitárias como Cryptocaryon irritans, Ichthyophthirius multifilis, Lerneae spp, Monogênea podem também ser perceptíveis durante a inspeção visual durante o recebimento devido os sinais clínicos que causam (COLORNI; BURGESS, 1997; MAGALHÃES, 2006; FRANCISFLOYD; REED, 2009; CARDOSO; BALIAN, 2016; CARDOSO et al., 2017c).

Não é possível conhecer o verdadeiro agente que causa a lesão, porém a suspeita já é um bom indicativo para recusar um lote de animais que pode colocar em risco outros animais do estabelecimento. A inspeção visual durante o recebimento compreende uma ação preventiva capaz de reduzir, consideravelmente, o risco de introduzir no sistema produtivo agentes patogênicos indesejáveis.

Uma outra medida preventiva muito importante para diminuir a possibilidade de ocorrência de determinados perigos, é adquirir animais de fornecedores que adotem boas práticas de higiene e manejo ou também disponham de programas de autocontrole sanitário da produção. 
A seleção de fornecedores que controlam a qualidade sanitária da sua produção é um fator contributivo para incremento técnico de toda a cadeia.

Se o estabelecimento comprador não conhece a estrutura do seu fornecedor, o simples recebimento de animais doentes já é um bom indicativo de que essa importante medida preventiva não acontece de maneira eficiente, e alguma etapa da produção está comprometendo o produto. Vale nesse ponto (recebimento) advertir o fornecedor para que sejam providenciadas melhorias ou até mesmo decido pelo encerramento das aquisições caso o problema persista. 
Quadro 13: Formulário para determinação do PCC1 para perigos de natureza bacteriana, viral, fúngica e parasitária na etapa de recebimento dos peixes ornamentais

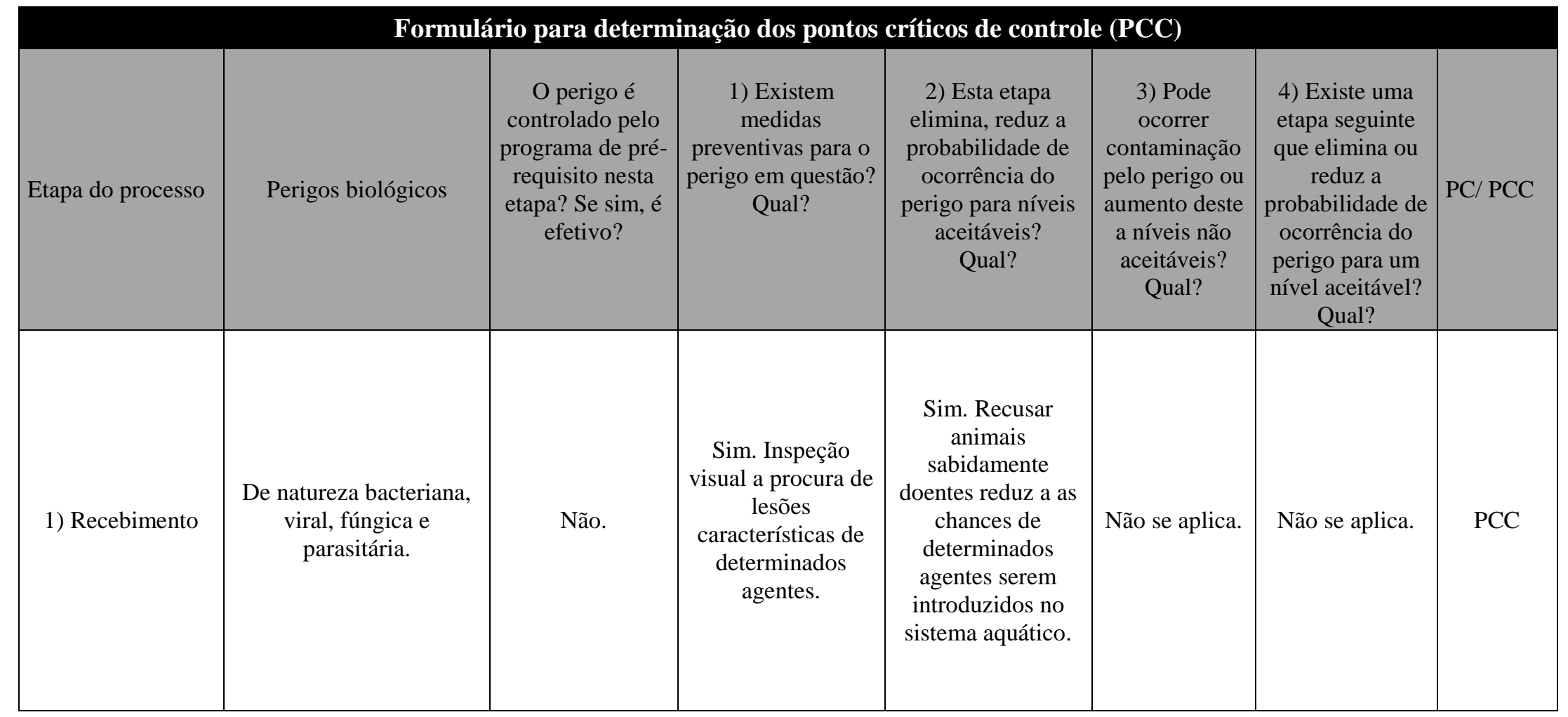

Fonte: Cardoso, 2017 


\subsubsection{Aclimatação}

Na etapa de aclimatação dos peixes foi determinado o segundo ponto crítico de controle [PCC2] (figura 39) dos perigos de natureza biológica. As perguntas utilizadas na árvore decisória estão no final desse item (quadro 4) para o melhor entendimento do leitor de como chegamos a este resultado.

Figura 39: PCC 2 na etapa de aclimatação dos peixes ornamentais

\section{Aclimatação}

Nessa etapa, a única medida preventiva que se faz eficiente, se aplica apenas a alguns tipos de perigos biológicos de natureza parasitária, tema já discutido no ítem 3.3.1.4.1 (Medidas Preventivas para os perigos de natureza parasitária em peixes ornamentais) do Capítulo 03, relembrado novamente aqui.

Muitos parasitas podem vir de "carona" com alguns peixes e serem imperceptíveis a olho nu(OATA, 2006). Como medida de redução e/ou eliminação desses parasitas em peixes de água salgada, preconiza-se a realização de banhos de água doce (REED; FRANCIS-FLOYD; KLINGER, 2012); e em peixes de água doce banhos de água salgada(SCHELKLE; DOETJES; CABLE, 2011), banhos rápidos (30 a 60 minutos) de formalina a $37 \%$ na dose de $0.125 \mathrm{ml} \mathrm{a} 0.250 \mathrm{ml}$ por litro de água para reduzir ou eliminar parasitas ciliados e flagelados (CARDOSO et al., 2017b), banhos rápidos (60 a 60 minutos) com praziquantel na dose de 20 mg por litro de água para eliminar ectoparasitas monogenéticos em peixes de água doce e água salgada (CARDOSO et al., 2017c) e banhos com outros agentes terapêuticos que por ventura possam ajudar na redução ou eliminação de determinados ectoparasitas imperceptíveis a olho nu.

Este PCC para redução ou eliminação de alguns perigos de natureza parasitária é muito importante dentro do sistema de comercialização dos peixes, pois muitos deles podem não ser eficientemente controlados na etapa posterior de armazenamento, que será discutida no próximo PCC3.

Para os perigos de natureza bacteriana, viral e fúngica a etapa de aclimatação não é um PCC, pois não foi encontrado na literatura científica nenhuma medida preventiva que possa eliminar, prevenir ou reduzir a ocorrência de maneira eficiente. 
() OATA

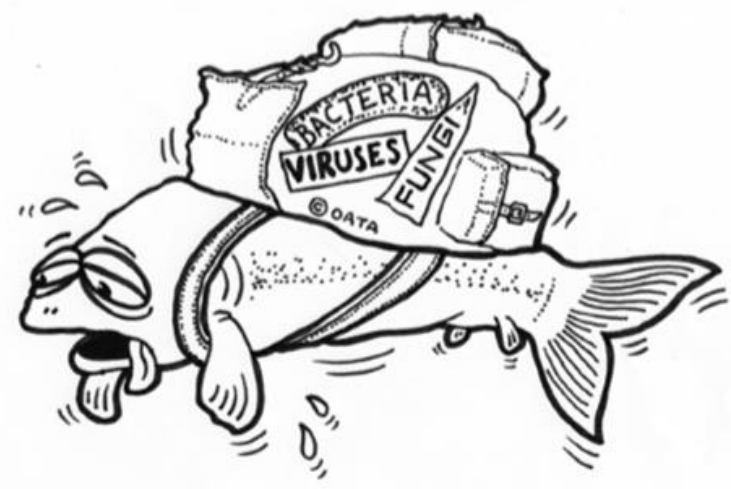

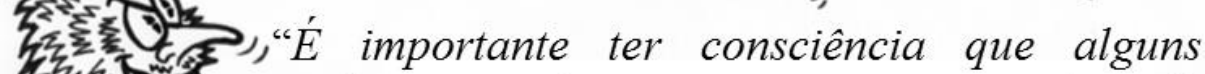
patógenos podem entrar no sistema aquático de "carona" em alguns peixes. Muitos estão na a fuse sublínica ou latente da doença".

M.N.

"2)

Fonte: OATA, 2006 adaptado por Cardoso, 2017. 
Quadro 14: Formulário para determinação do PCC2 para perigos de natureza parasitaria na etapa de aclimatação

\begin{tabular}{|c|c|c|c|c|c|c|c|}
\hline Etapa do processo & Perigos biológicos & $\begin{array}{l}\text { O perigo é } \\
\text { controlado pelo } \\
\text { programa de pré- } \\
\text { requisito nesta } \\
\text { etapa? Se sim, é } \\
\text { efetivo? }\end{array}$ & $\begin{array}{l}\text { 1) Existem medidas } \\
\text { preventivas para o } \\
\text { perigo em questão? } \\
\text { Qual? }\end{array}$ & $\begin{array}{l}\text { 2) Esta etapa } \\
\text { elimina, reduz a } \\
\text { probabilidade de } \\
\text { ocorrência do } \\
\text { perigo para } \\
\text { níveis aceitáveis? } \\
\text { Qual? }\end{array}$ & \begin{tabular}{|} 
3) Pode ocorrer \\
contaminação \\
pelo perigo ou \\
aumento deste a \\
níveis não \\
aceitáveis? Qual?
\end{tabular} & $\begin{array}{l}\text { 4) Existe uma etapa } \\
\text { seguinte que elimina } \\
\text { ou reduz a } \\
\text { probabilidade de } \\
\text { ocorrência do perigo } \\
\text { para um nível } \\
\text { aceitável? Qual? }\end{array}$ & $\mathrm{PC} / \mathrm{PCC}$ \\
\hline \multirow[t]{2}{*}{ 2) Aclimatação } & De natureza parasitária. & Não. & $\begin{array}{c}\text { Sim. Banho com } \\
\text { antiparasitários ou } \\
\text { água doce, assunto já } \\
\text { discutido no } \\
\text { Capítulo } 3 \mathrm{da} \\
\text { presente tese, item } \\
\text { 3.3.1.4.1 }\end{array}$ & $\begin{array}{l}\text { Sim. Reduz a } \\
\text { probabilidade de } \\
\text { ocorrência na } \\
\text { próxima etapa. }\end{array}$ & Não se aplica. & Não se aplica. & PCC \\
\hline & $\begin{array}{c}\text { De natureza } \\
\text { bacteriana,viral e } \\
\text { fúngica. }\end{array}$ & Não. & Não. & Não se aplica. & Não se aplica. & Não se aplica. & Não é PCC \\
\hline
\end{tabular}

Fonte:

Cardoso, 2017 
4.3.1.3 Armazenamento Na etapa de armazenamento dos peixes foi determinado o terceiro e último ponto crítico de controle [PCC3] (figura 40) dos perigos de natureza biológica. As perguntas utilizadas na árvore decisória estão no final desse item (quadro 5) para o melhor entendimento do leitor de como chegamos a este resultado.

Figura 40: PCC 3 na etapa de armazenamento dos peixes ornamentais

\section{Armazenamento}

Apesar dos PCC1 e PCC2 empregarem medidas de controle para os perigos de natureza bacteriana, viral, fúngica e parasitária eles não são capazes de eliminar 100\% dos agentes. Como já discutido anteriormente, alguns peixes podem estar na fase subclínica ou latente da doença.

Logo, o armazenamento é o último PCC onde podem ser aplicadas medidas preventivas para eliminar ou reduzir à quantidade aceitável os perigos biológicos aos quais os peixes ornamentais podem estar susceptíveis.

Nessa etapa assim como nas anteriores, é importante que os programas de pré-requisitos (boas práticas, discutido no Capítulo 02) sejam empregados corretamente. A água onde os animais são mantidos deve ser monitorada com relação aos parâmetros físico- químicos de qualidade para manter o máximo confortáveis possível os peixes, com a menor quantidade e intensidade de estímulos estressantes, além dos cuidados constantes com alimentação de qualidade e tratamento de doenças, quando detectadas.

A principal medida preventiva no PCC3, após os pré-requisitos citados anteriormente, é o tratamento da água de recirculação com luz ultravioleta e/ou ozonização, com o objetivo de reduzir ou eliminar determinados agentes(OATA, 2006).

Inúmeros trabalhos foram publicados demostrando a eficácia no tratamento da água de recirculação através do uso da luz ultravioleta (UV) e da ozonição para melhora da qualidade de água e redução ou eliminação de patógenos que causam doenças em peixes (SUMMERFELT, 2002; TANGO; GAGNON, 2003; VAN WEST, 2006; SHARRER; SUMMERFELT, 2007; SUMMERFELT et al., 2009; DECLERCQ et al., 2013; PARK et al., 2013; POWELL et al., 2015; SCHROEDER et al., 2015). Porém é importante salientar que o poder biocida da luz UV, depende da velocidade com o que a água passa pelo filtro de luz. Quanto menor a velocidade da água sob a luz UV, maior será a exposição do patógeno, e portanto maior o poder biocida da luz UV. E quanto maior a dosagem do ozônio, maior o 
poder oxidante e biocida sobre determinados patógenos. Lembrando que altas dosagens podem causar toxicidades para determinadas espécies de peixes(OATA, 2006). Alguns parasitas pluricelulares como as monogêneas, cestódeos, nematódeos e crustáceos nem sempre são eliminados com o uso dos métodos de tratamentos mencionados anteriormente, devendo ser prevenidos previamente nos PPC já anteriormente citados.

Apesar de ser um assunto de importância não será discutido aqui qual a melhor velocidade da água no filtro de luz UV para eliminar agentes patogênicos, nem a dosagem do gás ozônio na água, pois não faz parte do escopo desse trabalho. 
Quadro 15: Formulário para determinação do PCC3 para perigos de natureza bacteriana, viral, fúngica e parasitária na etapa de armazenamento dos peixes ornamentais

\begin{tabular}{|c|c|c|c|c|c|c|c|}
\hline Etapa do processo & Perigos biológicos & $\begin{array}{l}\text { O perigo é } \\
\text { controlado pelo } \\
\text { programa de pré- } \\
\text { requisito nesta } \\
\text { etapa? Se sim, é } \\
\text { efetivo? }\end{array}$ & $\begin{array}{c}\text { 1) Existem medidas } \\
\text { preventivas para o } \\
\text { perigo em questão? } \\
\text { Qual? }\end{array}$ & $\begin{array}{c}\text { 2) Esta etapa } \\
\text { elimina, reduz } \\
\text { a } \\
\text { probabilidade } \\
\text { de ocorrência } \\
\text { do perigo para } \\
\text { níveis } \\
\text { aceitáveis? } \\
\text { Qual? }\end{array}$ & $\begin{array}{c}\text { 3) Pode } \\
\text { ocorrer } \\
\text { contaminação } \\
\text { pelo perigo } \\
\text { ou aumento } \\
\text { deste a níveis } \\
\text { não } \\
\text { aceitáveis? } \\
\text { Qual? }\end{array}$ & $\begin{array}{l}\text { 4) Existe uma } \\
\text { etapa seguinte } \\
\text { que elimina ou } \\
\text { reduz a } \\
\text { probabilidade de } \\
\text { ocorrência do } \\
\text { perigo para um } \\
\text { nível aceitável? } \\
\text { Qual? }\end{array}$ & $\mathrm{PC} / \mathrm{PCC}$ \\
\hline 3) Armazenamento & $\begin{array}{c}\text { De natureza bacteriana, } \\
\text { viral, fúngica e } \\
\text { parasitária. }\end{array}$ & $\begin{array}{c}\text { Sim. O assunto foi } \\
\text { discutido no } \\
\text { Capítulo } 02 \mathrm{da} \\
\text { presente tese ítem } \\
\text { 2.3.6.3 - } \\
\text { Armazenamento }\end{array}$ & $\begin{array}{c}\text { Sim. Reduz a } \\
\text { probabilidade. O } \\
\text { assunto foi discutido no } \\
\text { Capítulo } 3 \text { da presente } \\
\text { tese, itens 3.3.1.1.1, } \\
\text { 3.3.1.2.1, 3.3.1.3.1 e } \\
\text { 3.3.1.4.1. }\end{array}$ & Não se aplica. & Não se aplica. & Não se aplica. & PCC \\
\hline
\end{tabular}

Fonte: Cardoso, 2017. 


\subsubsection{Captura}

$\mathrm{Na}$ etapa de captura dos peixes ornamentais para embalagem e venda não foi determinado PCC. Nessa etapa há um Ponto de Controle [PC1] (figura 41) dos perigos de natureza biológica. As perguntas utilizadas na árvore decisória estão no final desse item (quadro 6) para o melhor entendimento do leitor de como chegamos a este resultado.

Figura 41: PC na etapa de captura dos peixes ornamentais

\section{Captura}

\section{PC}

Esse PC é controlado pelo programa de pré-requisitos, discutido no item 2.3.6.4 (Captura), do Capítulo 02 da presente tese.

Todos os utensílios utilizados nas práticas de rotina devem ser exclusivos para cada sistema aquático, impedindo contaminação cruzada entre um sistema e outro. Finalizado um ciclo de trabalho, todos os equipamentos e utensílios devem ser corretamente higienizados (OIE, 2012), seguindo um procedimento operacional pré-estabelecido e padronizado. É importante que as mãos também sejam higienizadas e em alguns casos os utensílios pessoais como botas de borracha ou qualquer outro que possa entrar em contato com a água.

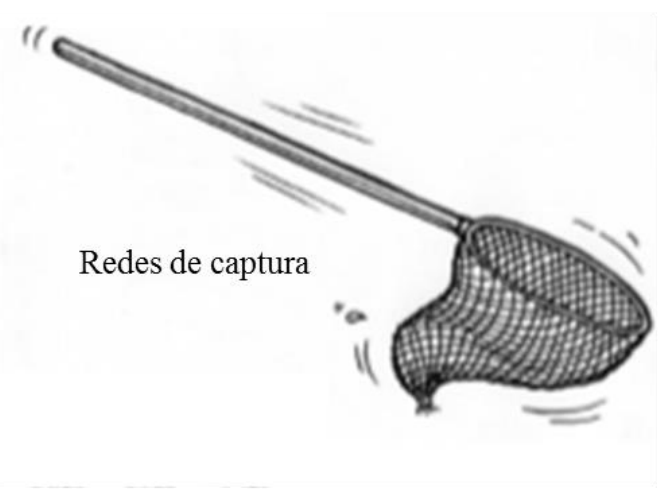

Mãos

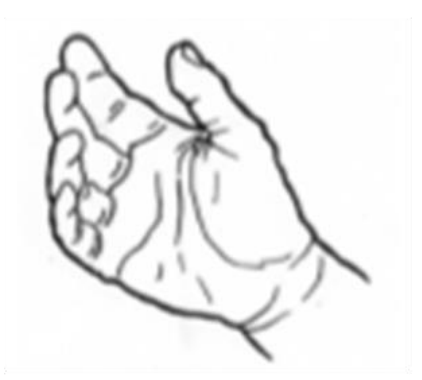

Utensílios para armazenamento

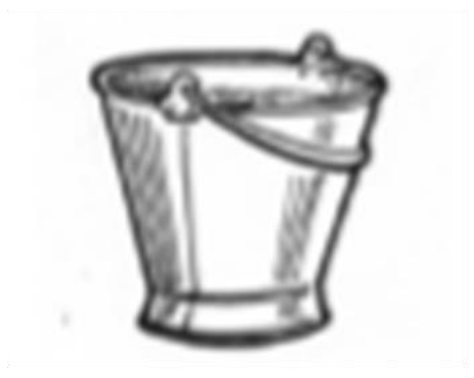

Utensílios de uso pessoal

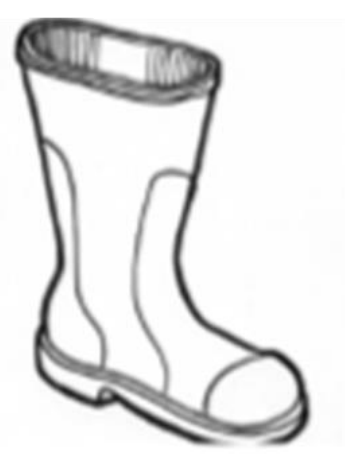


Quadro 16: Formulário para determinação do PC1 para perigos de natureza bacteriana, viral, fúngica e parasitária na etapa de captura dos peixes ornamentais

\begin{tabular}{|c|c|c|c|c|c|c|c|}
\hline Etapa do processo & Perigos biológicos & $\begin{array}{l}\text { O perigo é controlado } \\
\text { pelo programa de pré- } \\
\text { requisito nesta etapa? Se } \\
\text { sim, é efetivo? }\end{array}$ & $\begin{array}{c}\text { 1) Existem } \\
\text { medidas } \\
\text { preventivas para o } \\
\text { perigo em questão? } \\
\text { Qual? }\end{array}$ & $\begin{array}{c}\text { 2) Esta etapa } \\
\text { elimina, reduz } \\
\text { a } \\
\text { probabilidade } \\
\text { de ocorrência } \\
\text { do perigo para } \\
\text { níveis } \\
\text { aceitáveis? } \\
\text { Qual? }\end{array}$ & $\begin{array}{l}\text { 3) Pode ocorrer } \\
\text { contaminação } \\
\text { pelo perigo ou } \\
\text { aumento deste } \\
\text { a níveis não } \\
\text { aceitáveis? } \\
\text { Qual? }\end{array}$ & $\begin{array}{l}\text { 4) Existe uma } \\
\text { etapa seguinte } \\
\text { que elimina } \\
\text { ou reduz a } \\
\text { probabilidade } \\
\text { de ocorrência } \\
\text { do perigo } \\
\text { para um nível } \\
\text { aceitável? } \\
\text { Qual? }\end{array}$ & $\mathrm{PC} / \mathrm{PCC}$ \\
\hline 4) Captura & $\begin{array}{l}\text { De natureza } \\
\text { bacteriana, viral, } \\
\text { fúngica e } \\
\text { parasitária. }\end{array}$ & $\begin{array}{c}\text { Sim. O assunto é } \\
\text { discutido no Capítulo } 02 \\
\text { da presente tese item } \\
\text { 2.3.6.4 - Captura } \\
\text { (utensílios individuais } \\
\text { por sistema aquático e } \\
\text { higienização). }\end{array}$ & $\begin{array}{l}\text { Não. É necessário } \\
\text { um controle para } \\
\text { garantir a } \\
\text { segurança, } \\
\text { discutido no } \\
\text { Capitulo } 02 \text { da } \\
\text { presente tese, item } \\
\text { 2.3.6.4 - Captura }\end{array}$ & Não se aplica. & Não se aplica. & Não se aplica. & $\mathrm{PC}$ \\
\hline
\end{tabular}




\subsubsection{Embalagem e distribuição}

Nas etapas de embalagem e distribuição também não foram encontrados PCC (figura 42) que ameacem a segurança sanitária dos peixes ornamentais, já que os animais já estão embalados e lacrados.

As perguntas utilizadas na árvore decisória estão no final desse item (quadro 7) para o melhor entendimento do leitor de como chegamos a este resultado.

Figura 42: Não há PCC nas etapas de Embalagem e Distribuição

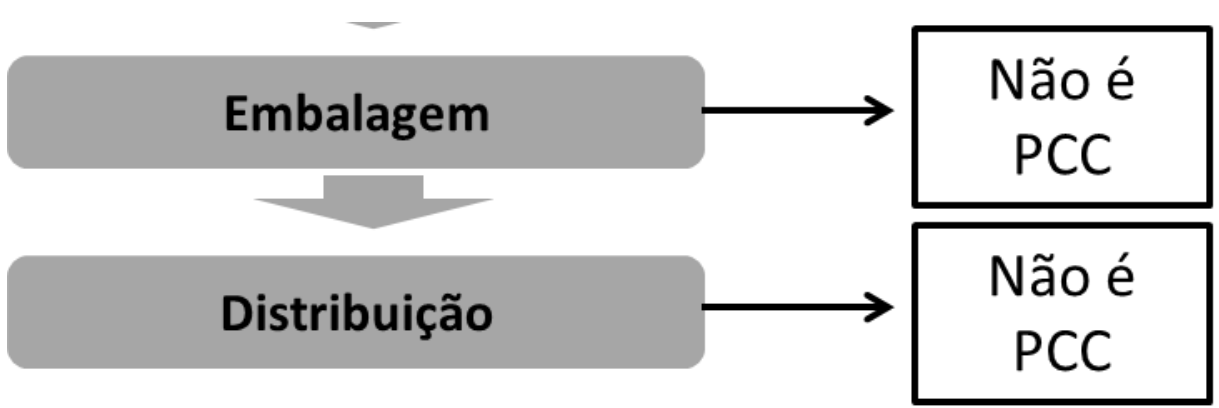

Nas etapas de embalagem e distribuição dos peixes ornamentais, os cuidados dizem respeito a atenção que deve ser tomada para que os mesmos não se estressem excessivamente como já discutido nos itens 2.3.6.5 (Embalagem) e 2.3.6.6 (Transporte/ Distribuição) do Capítulo 02 da presente tese.

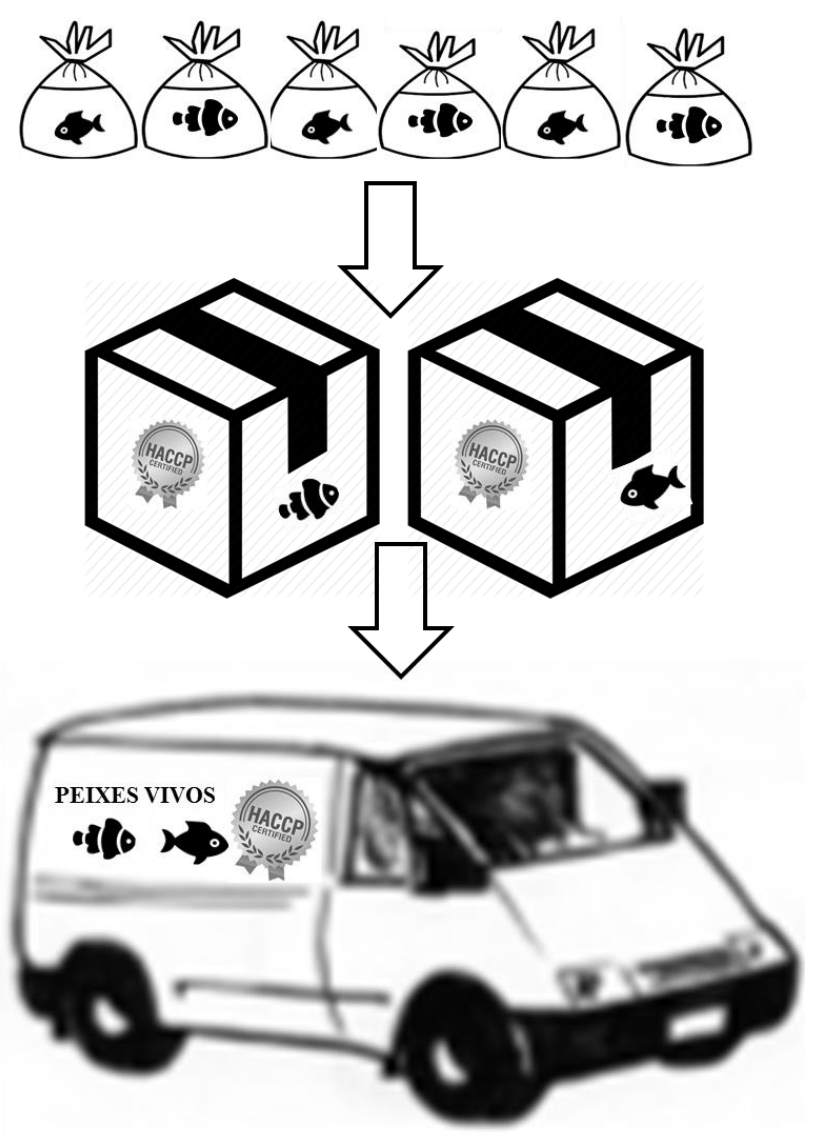


Quadro 17: Formulário para determinação do não PCC 2 e 3 para perigos de natureza bacteriana, viral, fúngica e parasitária na etapa de embalagem e distribuição dos peixes ornamentais

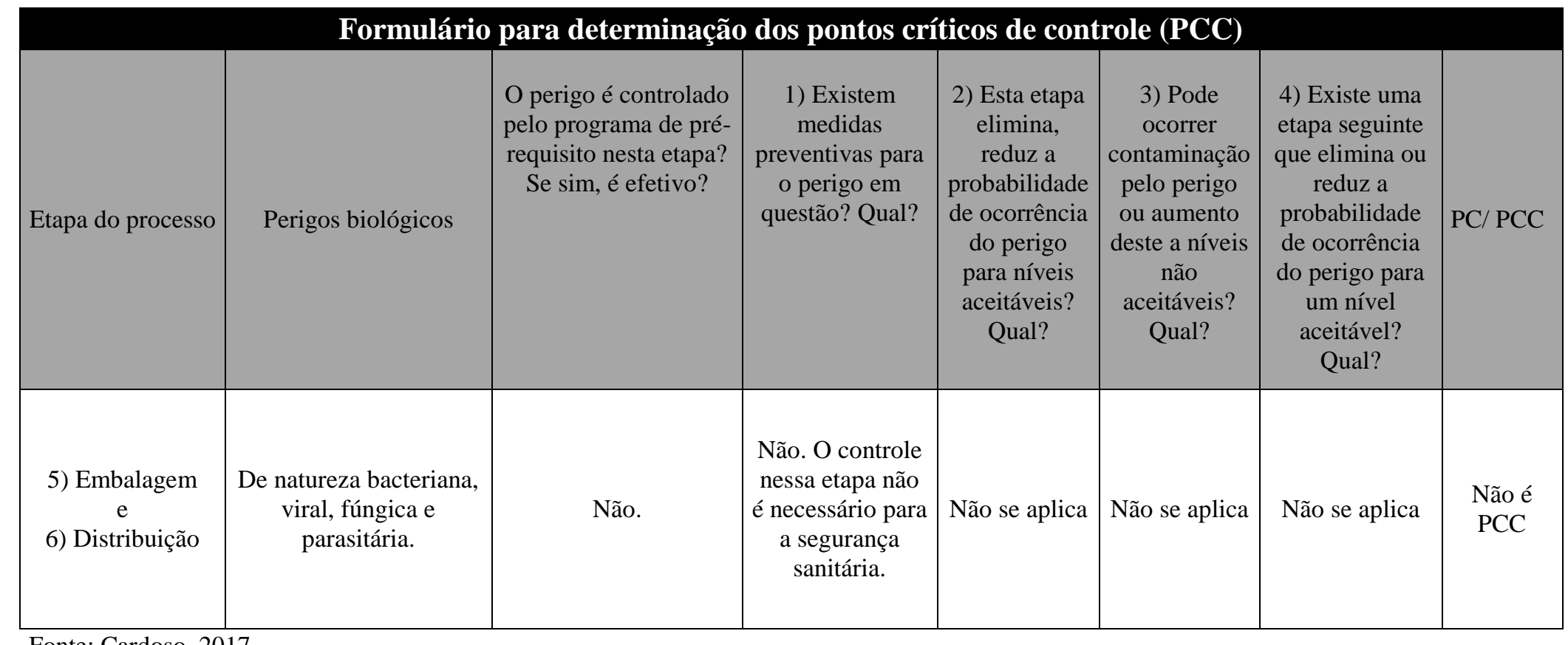

Fonte: Cardoso, 2017. 


\subsubsection{Limites Críticos de Controle (Princípio 3)}

Como não há na literatura científica parâmetros que podem ser medidos com relação aos perigos para cada PCC, determinou-se um formulário orientativo (quadro 8) para saber quando um PCC está sob controle e quando o limite crítico é considerado inaceitável.

Quadro 18: Formulário dos Limites Críticos dos PCC

\begin{tabular}{|c|c|c|c|}
\hline \multicolumn{4}{|c|}{ Limites Críticos de Controle } \\
\hline PCC & Etapa & O PCC está sob controle quando: & $\begin{array}{l}\text { O limite crítico do PCC é } \\
\text { considerado inaceitável quando: }\end{array}$ \\
\hline PCC1 & Recebimento & $\begin{array}{l}\text { Os animais recebidos nessa etapa } \\
\text { estão em condições sanitárias } \\
\text { satisfatórias (sem sinais de agentes } \\
\text { patogênicos ou lesões) durante a } \\
\text { inspeção visual. }\end{array}$ & $\begin{array}{l}\text { Os animais recebidos apresentam } \\
\text { lesões que sugerem infecção ou } \\
\text { infestação por qualquer um dos } \\
\text { perigos biológicos de natureza } \\
\text { bacteriana, viral, fúngica e } \\
\text { parasitária. }\end{array}$ \\
\hline PCC2 & Aclimatação & $\begin{array}{l}\text { Os procedimentos de tratamento } \\
\text { preventivo para redução ou } \\
\text { eliminação dos perigos de natureza } \\
\text { parasitária são empregados } \\
\text { corretamente nessa etapa. }\end{array}$ & $\begin{array}{l}\text { Mesmo que não haja lesões } \\
\text { aparentes nos animais na etapa } \\
\text { de aclimatação, as medidas } \\
\text { preventivas de tratamento não } \\
\text { estão sendo empregadas pelo } \\
\text { funcionário responsável pela } \\
\text { aclimatação. }\end{array}$ \\
\hline PCC3 & Armazenamento & $\begin{array}{l}\text { O tratamento da água de } \\
\text { recirculação com filtro de luz } \\
\text { ultravioleta e/ou ozonização está } \\
\text { sendo empregado eficientemente. }\end{array}$ & $\begin{array}{l}\text { O tratamento da água de } \\
\text { recirculação com filtro de luz } \\
\text { ultravioleta e/ou ozonização não } \\
\text { estão sendo empregados } \\
\text { corretamente. }\end{array}$ \\
\hline
\end{tabular}

Fonte: Cardoso, 2017

Dizer que o PCC está sob controle, significa dizer que os perigos biológicos de natureza bacteriana, viral, fúngica e parasitária que acometem os peixes ornamentais estão sendo controlados e estão sendo eliminados ou reduzidos a níveis aceitáveis com o intuito de manter a saúde dos animais comercializados. Porém quando os PCC não são eficientemente controlados, significa dizer que há grandes riscos dos animais estarem expostos aos perigos; exposição essa inaceitável pois permite que os animais tenham mais chances de não estar saudável.

\subsection{Monitoramento (Princípio 4)}

O monitoramento dos PCC garante o cumprimento dos limites críticos pré-determinados e permite também detectar desvios, isto é, situações fora dos limites, garantindo a ação corretiva imediata mantendo o processo sob controle em relação aos perigos controláveis. A 
etapa de monitoramento deverá conter, obrigatoriamente as seguintes informações conforme apresentado no quadro 9.

Quadro 19: Formulário com informações para o Monitoramento

\begin{tabular}{|c|c|c|c|c|c|}
\hline \multicolumn{6}{|c|}{ Monitoramento } \\
\hline PCC & Etapa & $\begin{array}{c}\text { O que } \\
\text { monitorar? }\end{array}$ & Como monitorar? & $\begin{array}{l}\text { Quando } \\
\text { monitorar? }\end{array}$ & $\begin{array}{l}\text { Responsável pelo } \\
\text { monitoramento? }\end{array}$ \\
\hline PCC1 & Recebimento & $\begin{array}{l}\text { Todo o } \\
\text { recebimento } \\
\text { dos animais, } \\
\text { anotando tudo. }\end{array}$ & $\begin{array}{c}\text { Fazendo as } \\
\text { inspeções a } \\
\text { procura de lesões } \\
\text { e anotando tudo } \\
\text { como já discutido } \\
\text { Capítulo } 02 .\end{array}$ & $\begin{array}{l}\text { Sempre que } \\
\text { houver } \\
\text { recebimento } \\
\text { de um novo } \\
\text { lote de } \\
\text { animais. }\end{array}$ & $\begin{array}{c}\text { Profissional } \\
\text { capacitado } \\
\text { designado pela } \\
\text { empresa para } \\
\text { executar tal fim. É } \\
\text { importante uma } \\
\text { ficha com o nome e } \\
\text { cargo do } \\
\text { profissional no } \\
\text { plano APPCC. }\end{array}$ \\
\hline PCC2 & Aclimatação & $\begin{array}{c}\text { Os } \\
\text { procedimentos } \\
\text { que estão } \\
\text { sendo } \\
\text { realizados na } \\
\text { aclimatação } \\
\text { para o controle } \\
\text { de parasitas. }\end{array}$ & $\begin{array}{l}\text { Quando possível } \\
\text { verificar se há } \\
\text { queda de } \\
\text { parasitas. }\end{array}$ & $\begin{array}{l}\text { Sempre que } \\
\text { houver um } \\
\text { novo lote de } \\
\text { animais para } \\
\text { ser } \\
\text { aclimatado. }\end{array}$ & $\begin{array}{c}\text { Profissional } \\
\text { designado pela } \\
\text { empresa para } \\
\text { executar tal fim. É } \\
\text { importante uma } \\
\text { ficha com o nome e } \\
\text { cargo do } \\
\text { profissional no } \\
\text { plano APPCC. }\end{array}$ \\
\hline PCC3 & Armazenamento & $\begin{array}{l}\text { A saúde dos } \\
\text { animais, o } \\
\text { correto } \\
\text { funcionamento } \\
\text { dos } \\
\text { equipamentos } \\
\text { para controle } \\
\text { de patógenos. }\end{array}$ & $\begin{array}{c}\text { Através da } \\
\text { inspeção da saúde } \\
\text { dos animais e } \\
\text { inspeção dos } \\
\text { equipamentos. }\end{array}$ & Diariamente. & $\begin{array}{c}\text { Profissional } \\
\text { designado pela } \\
\text { empresa para } \\
\text { executar tal fim. É } \\
\text { importante uma } \\
\text { ficha com o nome e } \\
\text { cargo do } \\
\text { profissional no } \\
\text { plano APPCC. }\end{array}$ \\
\hline
\end{tabular}

Fonte: Cardoso, 2017

O monitoramento do PCC1 acontece na etapa de recebimento dos peixes ornamentais, observando os animais desde o veículo de transporte, passando pela inspeção visual das embalagens com o intuito de detectar lesões causadas por perigos de natureza bacteriana, viral, fúngica e parasitária. É importante que o monitoramento do PCC1 ocorra a todo e qualquer recebimento de novo lote, por profissional treinado, designado pela empresa para executar tal fim. É importante elaborar uma ficha com (o quê, quando, como, quem, referindo nome do fornecedor, data) o nome e cargo do profissional no plano APPCC. O monitoramento do PCC1 quando executado por profissional capacitado permitirá o recebimento apenas de animais que estejam em condições sanitárias satisfatórias 
(aparentemente saudáveis) e será a primeira barreira estabelecida pelo plano APPCC com o intuito de evitar a incidência de doenças. Embora seja uma barreira, não é 100\% efetiva, pois como já dito anteriormente muitos animais podem ser portadores assintomáticos de patógenos.

O monitoramento do PCC2 acontece na aclimatação dos peixes ornamentais. Aqui o intuito é aplicar controle como banhos para que alguns parasitas se desprendam da pele ou brânquias do animal. Deve ser realizado em toda aclimatação, pois muitos peixes podem ter parasitas não aparentes a olho nu que podem ter passado despercebido durante o recebimento. Esse procedimento de controle no PCC2 também deve ser executado por profissional capacitado e será a segunda barreira para patógeno de natureza parasitária. Vale relembrar que o procedimento de controle do PCC2 é apenas para alguns ectoparasitas e essa etapa não é PCC para doenças de natureza bacteriana, viral e parasitária. Não foram encontradas na literatura científica, até o tempo de redação deste texto, orientações técnicas para controlar os perigos dessa natureza antes dos peixes serem introduzidos no sistema (aclimatação).

Por fim o monitoramento do PCC3 acontece na etapa de armazenamento (estocagem) dos animais. Deve-se ser avaliada a saúde dos animais e o correto funcionamento dos equipamentos para o tratamento de água como luz UV e Ozônio. Esse monitoramento deve ser realizado no mínimo três vezes ao dia, no início e final do expediente e meio do dia. Também deve ser realizado por um profissional capaz de reconhecer alterações na aparência e comportamento dos animais, indicativos de comprometimento da saúde e também alterações do bom funcionamento dos equipamentos.

\subsubsection{Ações Corretivas (Princípio 5)}

Sempre que um PCC estiver fora de controle as seguintes ações contidas no quadro 10 devem ser observadas e executadas pela equipe: 
Quadro 20: Formulário de ações corretivas

\begin{tabular}{|c|c|c|c|c|c|}
\hline \multicolumn{6}{|c|}{ Ações Corretivas para PCC fora do controle } \\
\hline PCC & Etapa & $\begin{array}{l}\text { Ação a ser } \\
\text { executada? }\end{array}$ & $\begin{array}{l}\text { Quem deve } \\
\text { ser } \\
\text { informado? }\end{array}$ & O que fazer? & $\begin{array}{l}\text { Responsável } \\
\text { pela decisão? }\end{array}$ \\
\hline PCC1 & Recebimento & $\begin{array}{l}\text { Recusar os } \\
\text { animais com } \\
\text { patógenos visíveis } \\
\text { a olho nu ou } \\
\text { animais com } \\
\text { sinais clínicos de } \\
\text { lesões causado por } \\
\text { patógenos. }\end{array}$ & $\begin{array}{l}\text { Primeirament } \\
\text { e o } \\
\text { Responsável } \\
\text { Técnico da } \\
\text { empresa e os } \\
\text { fornecedores } \\
\text { dos animais. }\end{array}$ & $\begin{array}{l}\text { Recusa dos } \\
\text { animais e/ou } \\
\text { Advertência. }\end{array}$ & $\begin{array}{l}\text { Responsável } \\
\text { Técnico ou } \\
\text { outro } \\
\text { comprovadame } \\
\text { nte capacitado } \\
\text { para executar. }\end{array}$ \\
\hline PCC2 & Aclimatação & $\begin{array}{l}\text { Seguir as } \\
\text { recomendações } \\
\text { imputadas pelo } \\
\text { estabelecimento } \\
\text { durante a } \\
\text { aclimatação como } \\
\text { já mencionado no } \\
\text { item } 4.1 .2 \text { acima. }\end{array}$ & $\begin{array}{l}\text { Responsável } \\
\text { Técnico }\end{array}$ & $\begin{array}{l}\text { Fazer novos } \\
\text { treinamentos e } \\
\text { se for o caso } \\
\text { advertência dos } \\
\text { responsável } \\
\text { pela } \\
\text { aclimatação. }\end{array}$ & $\begin{array}{l}\text { Responsável } \\
\text { Técnico ou } \\
\text { superior. }\end{array}$ \\
\hline $\mathbf{P C C 3}$ & Armazenamento & $\begin{array}{l}\text { Investigar a causa } \\
\text { do porque ocorreu } \\
\text { a falha no controle } \\
\text { do PCC nessa } \\
\text { etapa. }\end{array}$ & $\begin{array}{l}\text { Responsável } \\
\text { Técnico }\end{array}$ & $\begin{array}{l}\text { Corrigir falhas, } \\
\text { sejam elas } \\
\text { humanas ou } \\
\text { técnicas. }\end{array}$ & $\begin{array}{l}\text { Responsável } \\
\text { Técnico ou } \\
\text { superior. }\end{array}$ \\
\hline
\end{tabular}

Fonte: Cardoso, 2017

As correções são extremamente importantes quando os limites críticos saem de controle, pois permite que os perigos voltem a ser controlados eficientemente, e as chances de animais saudáveis aumentam.

\subsubsection{Verificação (Princípio 6)}

Os seguintes procedimentos de verificação nos PCC estabelecidos são sugeridos:

\subsubsection{PCC1 (Recebimento)}


I. Envio de amostras de peixes ornamentais para diagnóstico laboratorial dos perigos

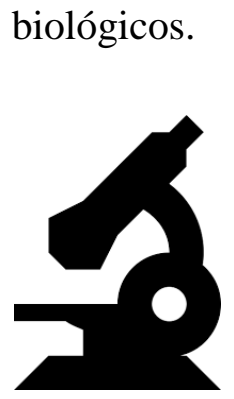

O envio de amostras é importante, pois como já discutido anteriormente muitos patógenos podem estar na fase subclínica da doença e não apresentam sinais clínicos visíveis a olho nu, passando assim despercebido por quem faz a inspeção visual no recebimento.

A verificação através de exames laboratoriais é importante também para certificar como está a qualidade dos fornecedores.

Recomenda-se que seja enviado amostras para diagnóstico laboratorial a cada três meses, ou a critério do Médico Veterinário Responsável Técnico que deverá realizar a coleta e decidir qual agente pesquisar.

II. Aplicação de questionário para avaliação do conhecimento dos responsáveis pelo recebimento e acompanhamento dos mesmos no momento do recebimento.

Outro procedimento de verificação que pode ser adotado é avaliar periodicamente, semestralmente ou quando julgar necessário, os conhecimentos relativos aos principais tópicos que devem ser observados pelo responsável pelo recebimento como já discutido no Capítulo 02, item 2.3.6.1 (Recebimento e Capítulo 03, item 3.3.1 (Perigos Biológicos).

O Médico Veterinário Responsável Técnico poderá, periodicamente, acompanhar o responsável durante o recebimento de animais com o intuito de checar se as práticas estão sendo executadas corretamente. Caso identifique não conformidades, corrigi-las imediatamente e realizar novos treinamentos.

III. Auditoria do correto preenchimento das planilhas de recebimento já discutidas no Capítulo 02, item 2.3.6.1.

As planilhas para recebimento dos animais deverão ser analisadas pelo Médico Veterinário Responsável Técnico, mensalmente, no mínimo, verificando seu correto preenchimento. Caso haja falhas, este deve identificar o motivo das incorreções, reunir os trabalhadores, esclarecer dúvidas e, se necessário, fazer novos treinamentos. 


\subsubsection{PCC2 (Aclimatação)}

\section{Aclimatação}

I. Aplicação de questionário para avaliar o conhecimento dos responsáveis pela aclimatação com relação aos perigos de natureza ectoparasitária e as medidas preventivas

A aplicação de um questionário para avaliação do conhecimento dos responsáveis pela aclimatação com relação aos perigos de natureza parasitária e medidas preventivas (já discutido no Capítulo 02, item 2.3.6.2 (Aclimatação) e Capítulo 03, item 3.3.1.4 (Perigos Biológicos de natureza parasitária) é outro procedimento de verificação.

Caso o Médico Veterinário Responsável Técnico verifique falhas no conhecimento no momento da aplicação do questionário, novos treinamentos técnicos deverão ser realizados com o intuito de esclarecer dúvidas e corrigir as falhas.

II. Auditoria mensal para verificação do procedimento de aclimatação com relação a aplicação de tratamento preventivo.

O Médico Veterinário Responsável Técnico poderá no mesmo dia da aplicação do questionário anteriormente citado, fiscalizar as atividades durante a aclimatação com o intuito de verificar se o que foi previamente estabelecido nos treinamentos técnicos (tratamento preventivo) está sendo executados corretamente.

Caso o Médico Veterinário Responsável Técnico verifique falhas nos procedimentos, novos treinamentos deverão ser realizados com o intuito de corrigir as falhas. 


\subsubsection{PCC3 (Armazenamento)}

\section{Armazenamento}

I. Análise microbiológica da água em laboratório para verificar a eficiência da lâmpada UV na esterilização da água dos aquários.

Uma forma de verificar a eficiência do filtro de luz ultravioleta no tratamento da água é através de exames microbiológico da água antes de passar pelo filtro e depois de passar pelo filtro. Um teste que pode ser feito para verificar a concentração de bactérias é a Contagem Padrão em Placas de bactérias heterotróficas. Caso não haja o tratamento da água há um aumento na concentração de bactérias na água que estão o tempo todo sendo eliminadas na água através da excreção dos peixes. Essas bactérias como já dito anteriormente podem agir como agente oportunistas e causar doenças nos peixes como já discutido no Capítulo 03.

II. Fazer teste da concentração de ozônio na saída o aparelho e do potencial de óxido redução (ORP) na água para verificar se o ozônio está funcionando eficientemente.

Para verificação do correto funcionamento o aparelho que gera ozônio na água é possível fazer o teste da concentração de ozônio com teste comercial que deve estar entre 0.34 a $0.39 \mathrm{mg} / \mathrm{L}$. Essa concentração de ozônio sendo liberada constantemente na água de recirculação vai manter a ORP entre 375-525 mV. O valor de ORP também pode ser verificado através de aparelho próprio (figura 43), e também é um indicativo do correto funcionamento do aparelho de ozônio(JOHNSON, 2001). A liberação constante de ozônio tem poder bactericida, viricida e parasiticida. Porém é importante salientar que doses de ozônio maior do que as anteriormente mensuradas podem causar toxicidade para os peixes e precisa ser verificado com mais frequência, se possível diariamente (SPILIOTOPOULOU et al., 2017). 
Figura 43: Aparelho para medir o potencial de óxido redução (ORP) da água e verificar o correto funcionamento o aparelho de ozônio.

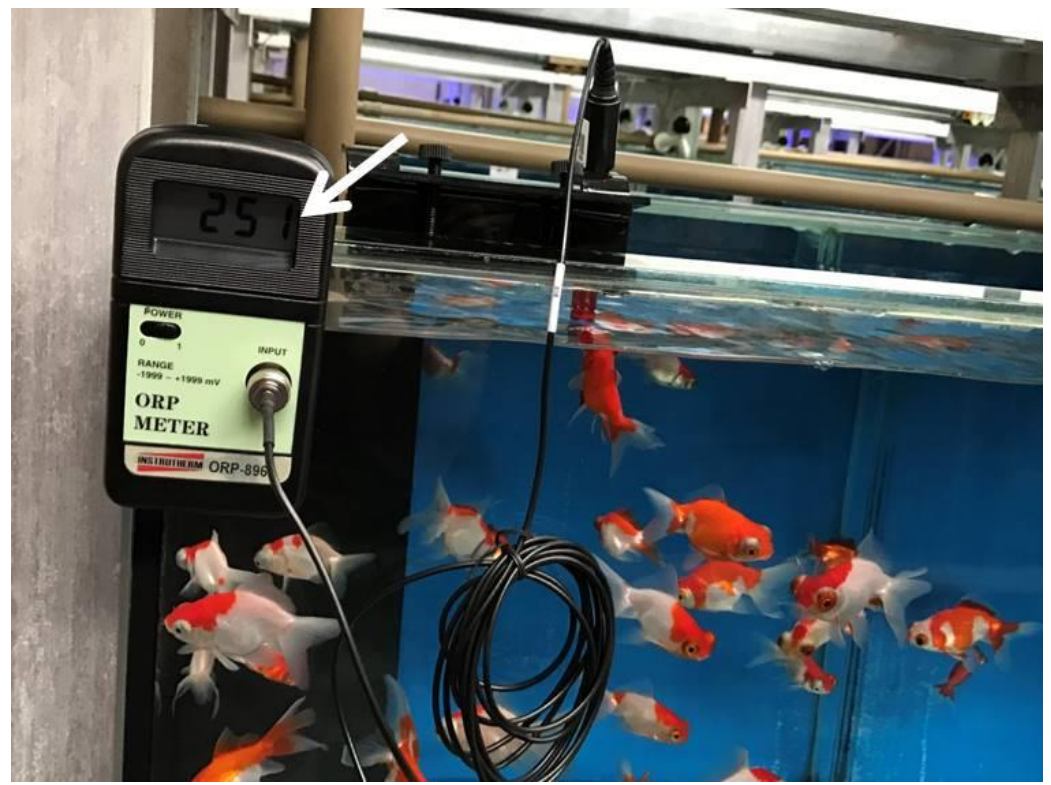

Fonte: Cardoso, 2017.

III. Fazer teste da matéria orgânica (figura 44) na água para verificar se a ozonização está diminuindo a concentração de matéria orgânica na água.

O ozônio dissolvido na água reduz os níveis de matéria orgânica, é efetivo na eliminação da cor, redução de nitrito, controle de algas, remoção da turbidez e melhora o processo de filtragem biológica. A diminuição da matéria orgânica na água também potencializa o efeito da irradiação ultravioleta na água (SPILIOTOPOULOU et al., 2017).

Figura 44: Teste da matéria orgânica na água dos aquários, após o tratamento com ozônio.

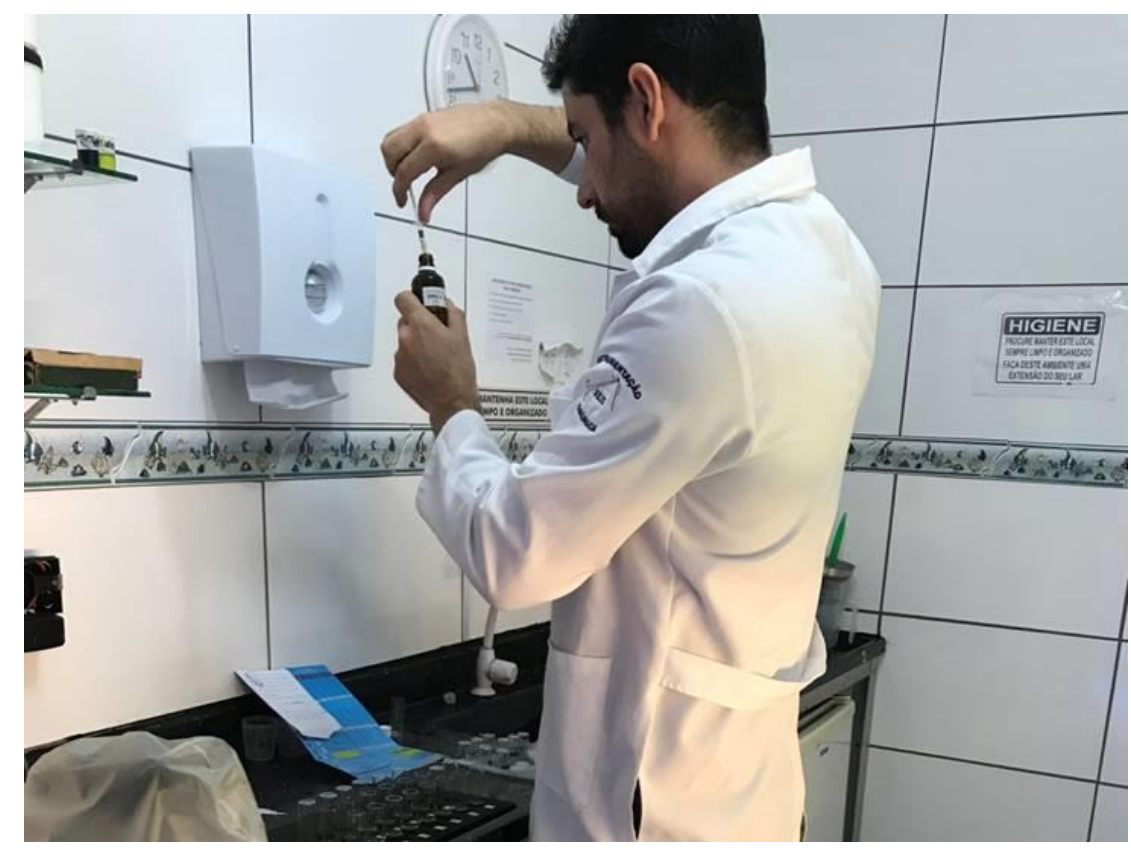

Fonte: Cardoso, 2017 


\subsubsection{Registro de Dados e Documentação (Princípio 7)}

Todos as informações colhidas devem ser corretamente preenchidas nas planilhas mencionadas anteriormente e arquivadas em pastas indicada por mês e por ano, em local específico, de forma que sejam de fácil acesso aos colaboradores e auditores.

Caso a empresa utilize arquivamento de dados em modalidade eletrônica, deve implantar sistemas de segurança capazes de garantir a fidedignidade das informações e controle de acessos. 


\subsection{CONSIDERAÇÕES FINAIS}

Não existe na literatura nacional relatos da aplicação da lógica do Sistema APPCC em centrais atacadistas de distribuição de organismos aquáticos ornamentais, e nem mesmo o sistema APPCC sendo utilizado como propósito de criação de PAS em centrais atacadistas, porém este se aplica de forma totalmente viável, útil, eficiente e eficaz.

Neste Capítulo foi possível a aplicação do sistema APPCC nas etapas de processamento dos peixes ornamentais, visto que existem perigos biológicos de natureza bacteriana, viral, fúngica e parasitária que podem comprometer os peixes ornamentais e medidas preventivas capazes de eliminar ou reduzir os riscos dos prejuízos causados por esses perigos a níveis aceitáveis. Para tanto foi necessário a criação de um guia prévio relacionado às boas práticas, controle de higiene e processos e Bem Estar Animal discutido no Capítulo 02.

Uma vez implementado o Sistema APPCC pelo dirigente da empresa, o sucesso no autocontrole da sanidade dos animais dependerá da ação constante e atenta dos detalhes, mão de obra capacitada e comprometida, investimentos contínuos, persistência em busca por melhorias e aperfeiçoamento constante dos procedimentos, processos e controle. A atualização técnica abrange todos os envolvidos com o plano de autocontrole, partindo do Médico Veterinário Responsável Técnico, Responsável Administrativo e os demais colaboradores da organização designados. 


\section{REFERÊNCIAS}

CARDOSO, P. H. M.; BALIAN, S. C. Lymphocystis vírus em peixes ornamentais importados para o Brasil. Revista de Educação Continuada em Medicina Veterinária e Zootecnia, v. 14, n. 1, p. 6-11, 2016.

CARDOSO, P. H. M.; BALIAN, S. de C.; MATUSHIMA, E. R.; PÁDUA, S. B. de; MARTINS, M. L. First report of scuticociliatosis caused by Uronema sp. in ornamental reef fish imported into Brazil. Braz. J. Vet. Parasitol., v. 26, n. 3, p. 1-6, 2017 a.

CARDOSO, P. H. M.; COSTA, A. R. da; PESTELli, M.; BALIAN, S. de C. Relato de caso de parasitismo por Monogênea no peixe ornamental Polypterus palmas no Brasil. Revista de Educacao Continuada do CRMV-SP, v. 15, n. 1, p. 30-36, 2017 b.

CODEX ALIMENTARIUS COMMISSION. General Principles of Food Hygiene. Codex Alimentarius - Basic Texts Food Hygiene, p. 21-31, 2003.

COLORNI, A.; BURGESS, P. Cryptocaryon irritans Brown 1951, the cause of "white spot disease" in marine fish: an update. Aquarium Sciences and Conservation, v. 1, n. 4, p. $217-$ 238, 1997.

DECLERCQ, A. M.; HAESEBROUCK, F.; VAN DEN BROECK, W.; BOSSIER, P.; DECOSTERE, A. Columnaris disease in fish: a review with emphasis on bacterium-host interactions. Veterinary Researchesearch, v. 44, p. 27, jan. 2013.

FDA. Análisis de peligros y puntos críticos de control. In: [s.l: s.n.]

FOSSA, S. A.; BASSLEER, G. M. O.; CHUAN, L. L.; PLOEG, A. Biossecurity in the ornamental aquatic industry. [s.l: s.n.]

FRANCIS-FLOYD, R.; REED, P. Ichthyophthirius Multifiliis ( White Spot ) Infections in Fish. IFAS Extension Univserity of Florida, v. CIR20, p. 1-5, 2009.

GRIM, C. J.; KOZLOV, E. V.; SHA, J.; FITTS, E. C.; VAN LIER, C. J.; KIRTLEY, M. L.; JOSEPH, S. J.; READ, T. D.; BURD, E. M.; TALL, B. D.; JOSEPH, S. W.; HORNEMAN, A. J.; CHOPRA, A. K.; SHAK, J. R. Characterization of Aeromonas hydrophila wound pathotypes by comparative genomic and functional analyses of virulence genes. mBio, v. $4, \mathrm{n}$. 2, p. 1-13, 2013. 
HEWIARACHCHI, D. C.; CHEONG, C. H.; GRAIN, C.; LIMITED, E.; LANE, R. SOME CHARACTERISTICS OF AEROMONAS HYDROPHILA AND VIBRIO SPECIES ISOLATED FROM BACTERIAL DISEASE OUT-. J. Natn. Sci. Coun. Sri Lanka, v. 22, n. 2, p. 261-269, 1994.

HULEBAK, K. L.; SCHLOSSER, W. Hazard Analysis and Critical Control Point (HACCP) history and conceptual overview. In: Risk Analysis, 3, Anais. 2002.

JOHNSON, J. V. Application of Ozone in Marine Parks and Large Aquariums Les applications de 1 ' ozone dans les Parcs marins et les grands Aquariums. Bulletin de I'Institut océonagraphique, v. 1, n. 1, p. 1-7, 2001.

MAGALHÃES, A. L. B. De. First record of lernaeosis in a native fish species from a natural environment in Minas Gerais state, Brazil. Pan-American Journal of Aquatic Sciences, v. 1, p. 8-10, 2006.

OATA, O. A. T. A. Biossecurity and the Ornamental Fish Industry. [s.l: s.n.].

OIE, W. O. for A. H. Methods for Disinfection of Aquaculture Establishments. In: Manual of Diagnostic Tests for Aquatic Animals 2014. [s.l: s.n.]p. 28-40.

PARK, J.; KIM, P.-K.; LIM, T.; DANIELS, H. V. Ozonation in seawater recirculating systems for black seabream Acanthopagrus schlegelii (Bleeker): Effects on solids, bacteria, water clarity, and color. Aquacultural Engineering, v. 55, p. 1-8, 2013.

PARKER, J. L.; SHAW, J. G. Aeromonas spp. clinical microbiology and disease. Journal of Infection, v. 62, n. 2, p. 109-118, 2011.

POWELL, A.; CHINGOMBE, P.; LUPATSCH, I.; SHIELDS, R. J.; LLOYD, R. The effect of ozone on water quality and survival of turbot (Psetta maxima) maintained in a recirculating aquaculture system. Aquacultural Engineering, v. 64, p. 20-24, 2015.

REED, P.; FRANCIS-FLOYD, R.; KLINGER, R. Monogenean Parasites of FishUniversity of Florida IFAS Extension, 2012. .

SCHELKLE, B.; DOETJES, R.; CABLE, J. The salt myth revealed : Treatment of gyrodactylid infections on ornamental guppies, Poecilia reticulata. Aquaculture, v. 311, n. 1-4, p. 74-79, 2011. 
SCHROEDER, J. P.; KLATT, S. F.; SCHLACHTER, M.; ZABLOTSKI, Y.; KEUTER, S.; SPIECK, E.; SCHULZ, C. Impact of ozonation and residual ozone-produced oxidants on the nitrification performance of moving-bed biofilters from marine recirculating aquaculture systems. Aquacultural Engineering, v. 65, p. 27-36, 2015.

SHARRER, M. J.; SUMMERFELT, S. T. Ozonation followed by ultraviolet irradiation provides effective bacteria inactivation in a freshwater recirculating system. Aquacultural Engineering, v. 37, n. 2, p. 180-191, 2007.

SPILIOTOPOULOU, A.; MARTIN, R.; PEDERSEN, L.-F.; ANDERSEN, H. R. Use of fluorescence spectroscopy to control ozone dosage in recirculating aquaculture systems. Water Research, v. 111, p. 357-365, 2017.

SUMMERFELT, S. T. Ozonation and UV irradiation - An introduction and examples of current applications. Aquacultural Engineering, v. 28, n. 1-2, p. 21-36, 2002.

SUMMERFELT, S. T.; SHARRER, M. J.; TSUKUDA, S. M.; GEARHEART, M. Process requirements for achieving full-flow disinfection of recirculating water using ozonation and UV irradiation. Aquacultural Engineering, v. 40, n. 1, p. 17-27, 2009.

TANGO, M. S.; GAGNON, G. a. Impact of ozonation on water quality in marine recirculation systems. Aquacultural Engineering, v. 29, p. 125-137, 2003.

VAN WEST, P. Saprolegnia parasitica, an oomycete pathogen with a fishy appetite: new challenges for an old problem. Mycologist, v. 20, p. 99-104, 2006. 


\section{APÊNDICE}

Apêndice 15: Árvore decisória para identificação dos PCC e PC

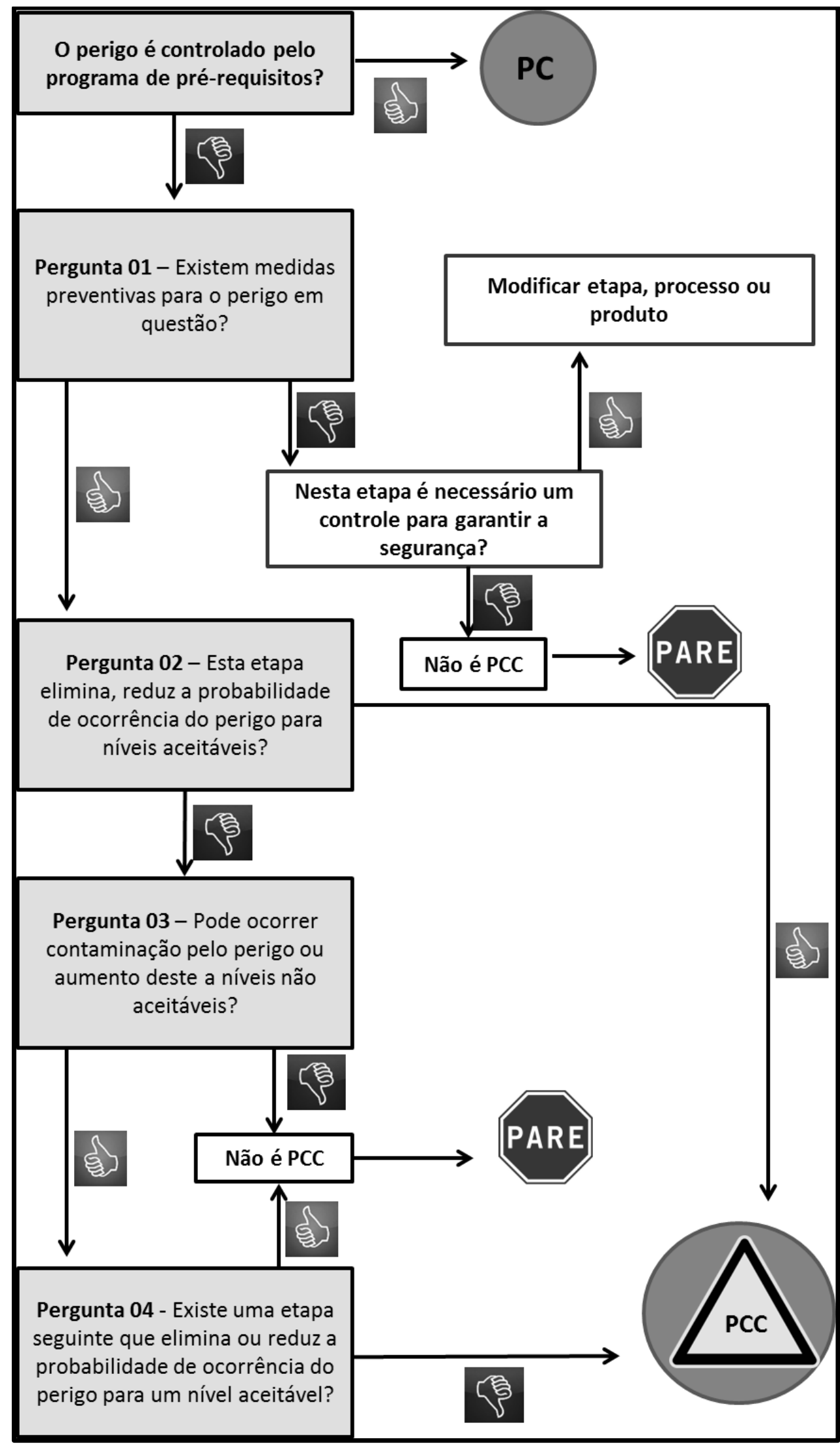

Fonte: Cardoso, 2017. 
Apêndice 16: Fluxograma de processamento

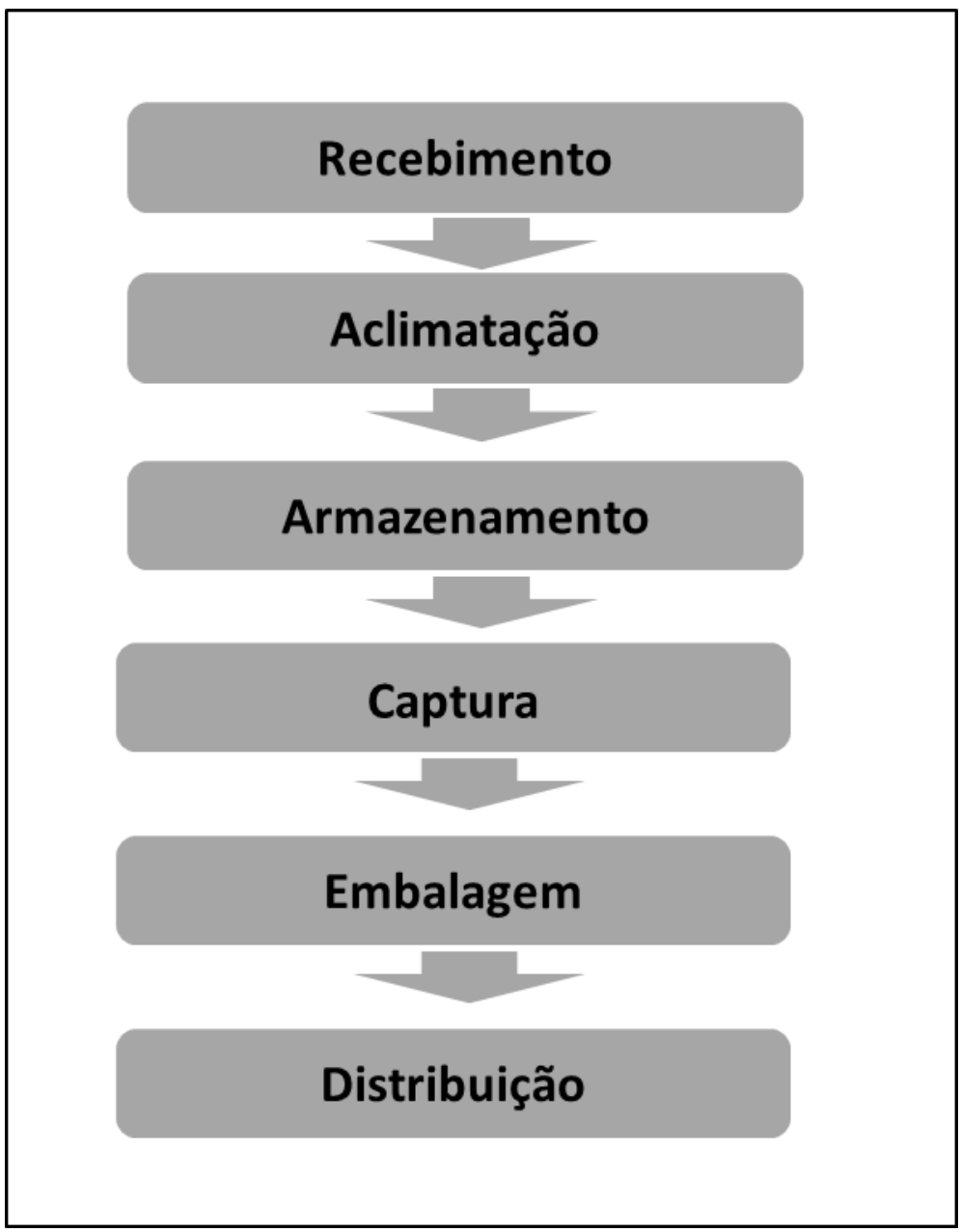

Fonte: Cardoso, 2017 


\section{CONSIDERAÇAÕES FINAIS}

Após o desenvolvimento do presente trabalho conclui-se que é possível a aplicação e implementação do Sistema APPCC em comércios atacadistas de peixes ornamentais. O Sistema APPCC é focado em etapas e processos pelo qual o produto passa, sendo possível o estabelecimento de PCCs e medidas de prevenção e controle, para reduzir, prevenir ou eliminar a ocorrência de determinados perigos biógicos de natureza bacteriana, viral, fúngica e parasitária no qual o produto (peixes ornamentais) seja susceptível. Sendo assim, a possibilidade de entregar animais saudáveis aos consumidores aumenta.

O sistema APPCC que é um programa de autrocontrole, também serve de base para criação de outros programas de autocontrole relacionado às boas práticas, controle higiênico sanitário, processos e Bem Estar Animal (como visto no Capítulo 02), sem o qual não seria possível sua aplicação de maneira eficaz.

Este documento dá subsídio a todos os outros elos da cadeia que desejem implementar o Sistema APPCC em seus sistemas produtivos para entregar animais saudáveis a seus consumidores, desde que devidamente aplicado à realidade de cada elo.

Porém são necessários mais estudos na área de aquicultura de peixes ornamentais no diz respeito a ocorrência de doenças e manejo da espécies comercializadas. A literatura científica no Brasil é escassa; muitos agentes que causam patogenia ainda estão sendo descobertos; e é provável que tenhamos muitas lacunas a serem preenchidas para o futuro. 


\section{REFERÊNCIAS}

ABINPET. Dados de Mercado. Associação Brasileira da Indústria de produtos para Animais de Estimação.

ARVANITOYANNIS, I. S.; VARZAKAS, T. H. Application of ISO 22000 and Failure Mode and Effect Analysis (FMEA) for industrial processing of salmon: a case study. Critical reviews in Food Science and Nutrition, v. 48, n. April 2015, p. 411-429, 2008.

BRASIL. Instrução Normativa N$^{\circ} 39$, de 4 de novembro de 1999. Ministério da Agricultura Pecuária e AbastecimentoDiário Oficial [da] União, Brasília, DF, 08 de nov. de 1999, 1999. .

BRASIL. Instrução Normativa $n^{0} 4$, de 4 de fevereiro de 2015. Ministério da Pesca e AquiculturaDiário Oficial [da] União, Brasília, DF, 09 de fev de 2015, BrasilMinistério da Pesca e Aquicultura, , 2015. .

BRASIL, M. da A. P. e A. Portaria $\mathbf{N}^{0}$ 99. Regimento Interno da Secretaria de Defesa Agropecuária.Brasilia, DF, 12 de maio de 2016 Diário Oficial da União, , 2016. .

BRASIL, M. da A. P. e A. Decreto $\mathbf{N}^{\mathbf{0}}$ 9.013. Regulamento da Inspeção Industrial e Sanitária de Produtos de Origem Animal. Brasilia, DF, 29 de março de 2017Diário Oficial da União, , 2017. .

CODEX ALIMENTARIUS COMMISSION. General Principles of Food Hygiene. Codex Alimentarius - Basic Texts Food Hygiene, p. 21-31, 2003.

DANIEL, H.; MARCOS, R.; AMORIM, D. S.; ALBERTO, J.; ROCHA, C. Exportação De Peixes Ornamentais Do Estado Do Amazonas, Bacia Ornamental Fish Export of the State of Amazonas, Amazon Basin ,. Boletim do Instituto de Pesca, v. 35, n. 2, p. 259-274, 2009.

FAO. Aquatic Biossecurity: a key for sustainable aquaculture development. In: Committee on Fisheries. [s.l: s.n.]p. 1-12.

MONDAL, S.; RAHMAN, M. M.; SAHA, D.; ADHIKARY, R. K.; HOSSAIN, M. B. Present Status of Good Aquaculture Practices ( GAP ) in Shrimp Farms of South-Western Coastal Area , Bangladesh. Middle-East Journal of Scientific Research, v. 14, n. 6, p. 873-878, 2013.

NOGA, E. J. Fish Disease: Diagnosis and Treatment. Second ed. Ames, Iowa, USA: 
Willey, 2010.

REILLY, A.; KAFERSTEIN, F. Food safety hazards and the application of the principles of the hazard analysis and critical control point (HACCP) system for their control in aquaculture production. Aquaculture Research, v. 28, n. 1994, p. 735-752, 1997.

TOOKWINAS, S.; KEERATIVIRIYAPORN, S. HACCP in shrimp farming. Acquaculture Asia, v. 9, n. 2, p. 29-33, 2004.

WHITTINGTON, R. J.; CHONG, R. Global trade in ornamental fish from an Australian perspective: the case for revised import risk analysis and management strategies. Preventive Veterinary Medicine, v. 81, n. 1-3, p. 92-116, 14 set. 2007.

YOUNG-MOK, K.; MYUNG-SUK, L.; TAE-JIN, K.; YONG-HYUN, C. Study on

Considering Points to Introcuce the HACCP Programs and Surveying at Aquaculture Farm of Rainbow Trout. v. 24, n. 2, p. 224-233, 2012. 


\section{GLOSSÁRIO}

Aferir: comparar as medidas com seus padrões específicos

Perigo: um agente físico, químico ou biológico que quando presente nos peixes ornamentais com potencial de causar prejuízos de natureza sanitária e econômica;

Biosseguridade: é a soma de todos os procedimentos aplicados para proteger organismos aquáticos ornamentais de contrair, carrear e disseminar doenças;

Calibrar: fazer ajuste de calibre com intuito de dar confiabilidade a um instrumento de medição;

Colaboradores: são funcionários ou até mesmo sócios de uma empresa que contribuem para resultados positivos na empresa.

Contaminação: presença de substâncias ou agentes estranhos de origem biológica, química ou física que sejam considerados nocivos para saúde dos animais.

Controle: situação onde os procedimentos corretos estão sendo aplicados e o processo está de acordo e o processo está de acordo com os limites pré-estabelecidos.

Desinfecção: é a redução, por meio de agentes químicos ou métodos físicos adequados, do número de microrganismos no ambiente, instalações, maquinários e utensílios, a um nível que não origine contaminação do produto que será elaborado.

Fluxograma: diagrama representativo das etapas individualizadas e apresentadas de forma sequencial, referente às etapas dos processos produtivos relacionados aos peixes ornamentais em um estabelecimento de aquicultura.

Pré - lavagem: remoção e descarte das partículas de residuais com água corrente.

Lavagem: aplicação de detergentes em concentração do produto químico, em temperatura adequada, tempo de contato do produto químico com superfície a ser lavada e ação mecânica. Limpeza: remoção de qualquer tipo de resíduo indesejável.

Higienização: limpeza e desinfecção.

Medida Preventiva: qualquer ação ou atividade que possa ser usada para evitar, eliminar, reduzir um perigo significativo e provável qualidade sanitária do produto.

Medir: determinar ou avaliar por meio de instrumento ou utensílio de medida.

Monitoramento: ato de verificar o cumprimento de uma especificação ou limite crítico de uma etapa do processo ou serviço.

Ozonição: é um método de tratamento de água que visa eliminar microrganismos nocivos pela adição de gás ozônio à água que tem poder oxidativo. 
Organograma: diagrama usado para representar as relações hierárquicas dentro de uma empresa, ou simplesmente a distribuição dos setores, unidades funcionais e cargos e a comunicação entre eles.

Osmose reversa: é um processo usado no tratamento de água por meio de separação por alta pressão através de membranas

Ponto de Controle (PC): etapa ou procedimento operacional em um processo, método de produção, ou em uma formulação, em que os perigos biológicos, químicos e físicos podem ser controlados através de programas de pré-requisitos (Boas práticas).

Programas de pré-requisitos: procedimentos, incluindo as boas práticas e os procedimentos padrão de higiene operacional, que são a base higiênica sanitária necessária para implementar um sistema APPCC adequado.

Responsável Técnico: médico veterinário responsável pelo controle sanitário dos estabelecimentos de aquicultura.

Risco: é a probabilidade de ocorrência de um evento adverso sobre a saúde humana e animal associada a sua severidade e as consequências econômicas que o evento implica;

Total de sólidos dissolvidos (TDS): é o conjunto de todas as substâncias orgânicas e inorgânicas contidas num líquido sob formas moleculares, ionizadas ou micro granulares. É um parâmetro de determinação da qualidade da água, pois avalia o peso total dos constituintes minerais presentes na água, por unidade de volume.

Verificação: O uso de métodos, procedimentos, ou testes por supervisores, pessoas indicadas ou inspetores oficiais para determinar se o sistema de gestão de qualidade sanitária, baseado nos princípios do sistema APPCC está funcionando para controlar os perigos ou se há necessidade de modificações. 